UNIVERSIDADE DE SÃO PAULO

INSTITUTO DE ARQUITETURA E URBANISMO

DISSERTAÇÃO DE MESTRADO

\title{
APROPRIAÇÃO DO ESPAÇO POR MORADORES DE CONJUNTOS HABITACIONAIS EM VIÇOSA-MG
}

\author{
Jansen Lemos Faria
}

Orientador: Dr. Miguel Antônio Buzzar

São Carlos, junho de 2018 



\title{
JANSEN LEMOS FARIA
}

\section{Apropriação do espaço por moradores de conjuntos} habitacionais em Viçosa - MG

\author{
Versão Corrigida
}

Dissertação apresentada ao Instituto de Arquitetura e Urbanismo da Universidade de São Paulo, como requisito para obtenção do título de Mestre.

Área de concentração 102132: Teoria e História da Arquitetura e Urbanismo.

Orientador: Professor Assoc. Miguel Antônio Buzzar

São Carlos 



\section{AUTORIZO A REPRODUCAO TOTAL OU PARCIAL DESTE TRABALHO, POR QUALQUER MEIO CONVENCIONAL OU ELETRONICO, PARA FINS DE ESTUDO E PESQUISA, DESDE QUE CITADA A FONTE}

Ficha catalográfica elaborada pela Biblioteca do Instituto de Arquitetura e Urbanismo com os dados fornecidos pelo(a) autor(a)

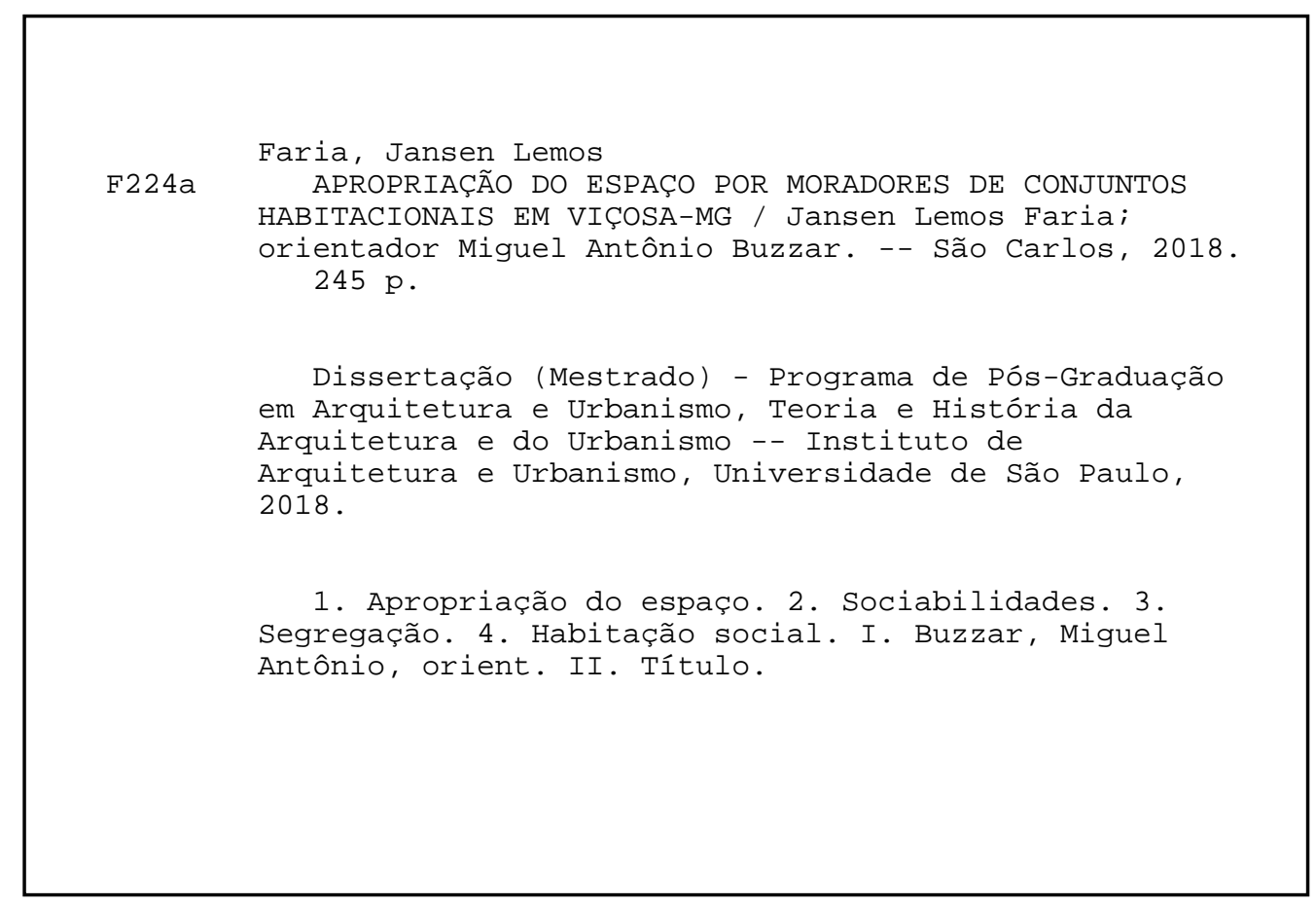

Bibliotecária responsável pela estrutura de catalogação da publicação de acordo com a AACR2:

Brianda de Oliveira Ordonho Sígolo - CRB - 8/8229 



\section{FOLHA DE JULGAMENTO}

\section{Candidato(a): Jansen Lemos Faria}

Título da dissertação: "Apropriação do espaço por moradores de conjuntos habitacionais em Viçosa-MG"

Data da defesa: 20/04/2018

Orientador: Prof. Dr. Miguel Antonio Buzzar

\section{Comissão Julgadora:}

$\underline{\text { Resultado: }}$

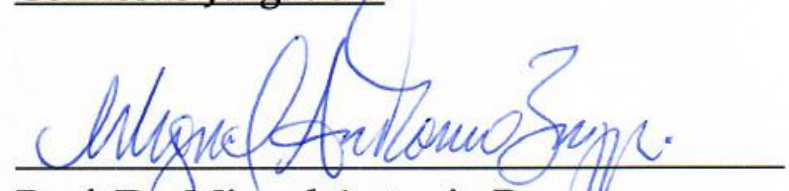

Prof. Dr. Miguel Antonio Buzzar (IAU/USP)

Não votante

Profa. Dra. Cibele Saliba Rizek

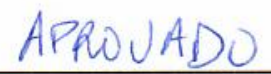

(IAU/USP)

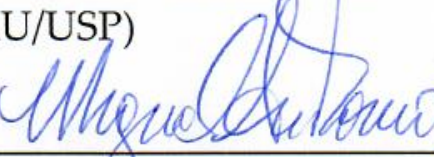

Profa. Dra. Maristela Siolari da Silva (UFV)

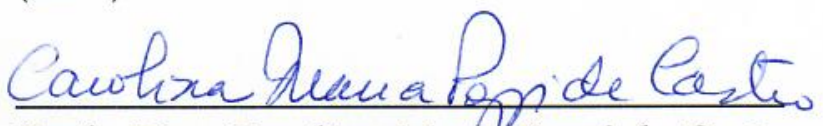

Profa. Dra. Carolina Maria Pozzi de Castro (UFABC)

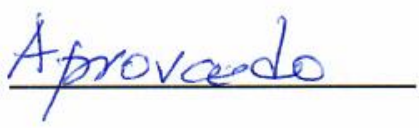

Coordenadora e Presidente da Comissão de Pós-Graduação do Programa de PósGraduação em Arquitetura e Urbanismo: Profa. Dra. Cibele Saliba Rizek. 


\section{Agradecimentos}

Agradeço à CAPES e ao CNPQ pelo auxílio financeiro em grande parte do percurso do trabalho. Meus agradecimentos ao IAU/USP e a todos os funcionários e funcionárias que me receberam de braços abertos. Agradeço às famílias entrevistadas pelo tempo e carinho com que me receberam. Agradeço também a todos os profissionais com os quais tive a oportunidade de conversar, entrevistar ou obter informações para o trabalho.

Sou muito grato por todo o apoio recebido dos amigos e amigas de sempre, que compartilharam das alegrias e dificuldades de mais essa etapa da minha vida. Agradeço também o apoio dos amigos e amigas que me acompanharam nos aprendizados diários no IAU/USP. Vocês foram fundamentais ensinando-me a cada dia a ser um pesquisador e uma pessoa melhor. Agradecimentos especiais ao Rodrigo Lima, Wesley Medeiros, Ana Luísa Figueiredo e Lucas Melchiore que foram ao mesmo tempo amigos e professores. E ao Dyego Digiandomenico, à Gabriele Landim e à Raiane Rosi pela companhia e pela ajuda nos momentos de aperto.

Agradeço aos professores e professoras com os quais tive contato nos últimos três anos. Foram anos de muito aprendizado e já levo um pouco de cada um de vocês para a minha carreira como pesquisador e docente. Agradecimentos também às Professoras Cibele Rizek (IAU-USP), Maristela Siolari (UFV) e Carolina de Castro (UFABC) pela atenção dispensada ao meu trabalho e pelas valiosas contribuições. Agradeço especialmente ao meu orientador, Professor Miguel Buzzar, pelos ensinamentos que levarei para a vida e pela solicitude e companheirismo.

Agradeço à minha família, que se provou mais uma vez ser o alicerce da minha vida. Em especial aos meus pais Annamaria e Paulinho, à minha irmã Anna Paula e à minha Tia Giovanna. Sem vocês nada disso seria possível. Agradeço à minha namorada que tanto me apoiou e que me ajudou a organizar a bagunça de pensamentos que ocupou minha cabeça durante a pesquisa. Agradeço a oportunidade de ver a vida de uma forma diferente pela experiência incrível e alegre de ser pai de uma menina maravilhosa. Cecília é um Sol que nos enche de vida.

Enfim, a todos e todas que de alguma forma ajudaram neste processo, o meu sincero agradecimento. 
"[...] a principal exigência de Marx, a saber, a apropriação, em nome da sociedade, do conjunto dos meios de produção pelo proletariado, alçado ao domínio político absoluto, constitui hoje a reivindicação de toda a classe revolucionária de trabalhadores, inclusive nos países românticos."

Friedrich Engels, 1887, no Prefácio à edição alemã de Sobre a Questão da Moradia (ENGELS, F. Sobre a questão da moradia. São Paulo: Boitempo, 2015, p. 28) 


\section{RESUMO}

FARIA, Jansen Lemos. Apropriação do espaço por moradores de conjuntos habitacionais em Viçosa - MG. 2018. Dissertação (Mestrado em Arquitetura e Urbanismo). Instituto de Arquitetura e Urbanismo. Universidade de São Paulo, São Carlos, 2018.

Este trabalho pretende realizar uma pesquisa exploratória visando o entendimento e a análise dos efeitos sociais e urbanos da implantação dos conjuntos habitacionais do Programa Minha Casa, Minha Vida (lei 11.977, 2009) na cidade de Viçosa, Minas Gerais, para os moradores das localidades, a partir do estudo sobre a apropriação do espaço. Desta forma a pesquisa coloca em foco o direito à cidade e as relações sociais e espaciais pela perspectiva do público-alvo dessa ação governamental. Compreende-se como objetivo maior de ações e políticas públicas voltadas às parcelas social e economicamente vulneráveis, em tese, o acesso à cidadania. Assim, a pesquisa procura relacionar seus elementos centrais e objeto de estudo a grandes temas como o da cidadania, da moradia adequada, das sociabilidades, do espaço público, do direito à cidade e a da segregação socioespacial. Dada a abrangência e a visibilidade do programa, muitas pesquisas foram realizadas tendo-o como objeto de estudo e variados questionamentos foram levantados, sobretudo em relação a seu desenho político. Porém, há uma lacuna no que diz respeito às relações sociais e urbanas estabelecidas pelos moradores dos conjuntos, para além da avaliação quantitativa baseada em questionários padrões, sobretudo em se tratando de cidades de pequeno e médio porte, onde a escala da cidade muda a perspectiva de análise dos elementos. Conclui-se, a partir da análise empírica e das entrevistas e com base no referencial teórico e documental, que os processos e a as ausências de apropriações dos espaços estão ligadas à tipologia institucional do Programa. Esperase que a pesquisa possa contribuir para elucidar relações socioespaciais de moradores realocados para conjuntos habitacionais e auxiliar em estudos correlatos em diferentes campos do conhecimento, como para o urbanismo, a sociologia urbana e a geografia.

PALAVRAS-CHAVE: apropriação do espaço; sociabilidades; segregação; habitação social. 


\begin{abstract}
FARIA, Jansen Lemos. Appropriation of space by residents of the governmental housing estates in Viçosa-MG. 2018. Dissertação (Mestrado em Arquitetura e Urbanismo). Instituto de Arquitetura e Urbanismo. Universidade de São Paulo, São Carlos, 2018.
\end{abstract}

This work intends to realize an exploratory search in order to understand and analyze the social and urban effects of the deployment of "My House, My Life" housing estates (law 11.977, 2009) in the city of Viçosa, Minas Gerais, by the residentes, starting from the appropriation processes of space. Thus, the research foregrounds the right to the city and the social and spatial relations by the perspective of the target audience of this program. The access to citizenship, in theory, is understood as the larger goal of the public politics aimed at vulnerable economically groups. So, the research seeks to relate its central matters and its study object with broad knowledges like as the citizenship, the decent housing, the sociabilities, the public spaces, the right to the city and the socio-spatial segregation. Many researches have been done using this public program as the object of study because of its big scope and visibility. Many different questions have been raised, particularly speaking of its political aspects. However there is a gap in what it refers to the social and urban relations established by the housing estates residents, for beyond the quantitative evaluation based on patterned questionnaires, especially refering to small and medium cities, where the urban scale changes the perspective of analisys. It is concluded that the processes observed and the absence of appropriations of those spaces, occupied by the residents, are related to the institutional typology of the Program. It is expected to contribute to elucidate socio-spatial relations of residents that have been taken from precarious situation and moved to this housing estates. It is also expected to help similar studies in different fields of knowledge like urbanism field, urban sociology and geography.

KEYWORDS: appropriation of space; sociabilities; segregation; social housing. 


\section{LISTA DE FIGURAS}

Figura 01 Maquete do Plan Voisin (1925) de Le Corbusier para Paris. Exemplo do pensamento corbusiano para o urbanismo modernista

Figura 02 Capa do livro de fotografias de Nigel Henderson

Figura 03 Pixação em Paris no Maio de 68

Figura 04 Vista de Mourenx e o complexo industrial de Lacq

Figura 05 Mourenx e o complexo industrial de Lacq

Figura 06 Vista do centro de Viçosa em 1898

Figura 07 Vista para os principais edifícios da UFV na década de 1920

Figura 08 Vista da Praça central Silviano Brandão, na década de 1940

Figura 09 Vista aérea da cidade para a UFV. Foto do início dos anos 2000

Figura 10 Imagem de satélite destacando a fronteira entre a malha urbana de Viçosa e a UFV

Figura 11 Imagem aérea de Viçosa na década de 1950

Figura 12 Vista do centro a partir de área próxima da favela "Rebenta Rabicho", na década de 1970

Figura 13 Dia da "inauguração" do loteamento Nova Viçosa, em 1978

Figura 14 Edifício Burle Marx II, em 2015

Figura 15 Viçosa no início da década de 2010

Figura 16 Mapa de assentamentos precários de Viçosa (2012).

Figura 17 Entrada e guarita do Bairro Inconfidentes

Figura 18 Partes da UFV, do centro e das periferias de Viçosa em 2015

Figura 19 Imagem de satélite destacando barreira geográfica entre a malha urbana o os conjuntos

Figura 20 Conjunto BJC pouco antes da inauguração, em 2011

Figura 21 Conjunto BJC pouco tempo depois da inauguração, em 2011

Figura 22 Escada de escoamento de águas pluviais

Figura 23 Rua do Conjunto CSF (Sol Nascente), em 2016

Figura 24 Vetores de crescimento e localização dos conjuntos

Figura 25 Áreas elencadas para a implementação de novas HIS 
Figura 26 Último "predinho" da ocupação no Alto Santa Clara

Figura 27 Escola Municipal Pedro Gomide Filho, no Alto Santa Clara

Figura 28 Garagem da casa de uma das moradoras

Figura 29 Acesso à praça do Conjunto Sol Nascente

Figura 30 Praça do Conjunto Coelhas em 2015

Figura 31 Feira de artesanato na Praça do Rosário, centro da cidade.

Figura 32 Praça do Conjunto Coelhas em 2016.

Figura 33 Criança brincando de pipa no terreno baldio.

Figura 34 Interior da residência da entrevistada 14.

Figura 35 Muro de uma das residências do Conjunto BJC, o Coelhas.

Figura 36 Mesa de refeição da família da entrevistada 13, Conjunto BJC.

Figura 37 Área externa da casa da entrevistada 13

Figura 38 Uma das residências cujo proprietário improvisou uma cerca

Figura 39 Mesa que exerce diferentes funções para os moradores 


\section{LISTA DE MAPAS}

Mapa 01 Mapa de localização dos bairros na malha urbana

Mapa 02 Mapa de localização dos conjuntos na malha urbana

Mapa 03 Mapa de localização das principais áreas públicas de lazer

Mapa 04 Mapa de localização dos equipamentos públicos

Mapa 05 Mapa de mobilidade 



\section{SUMÁRIO}

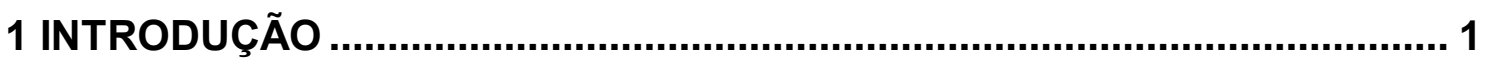

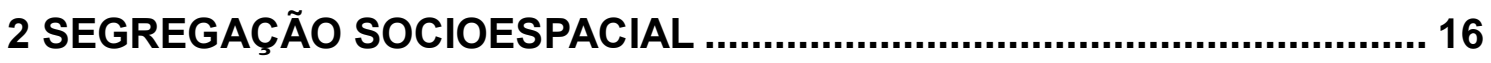

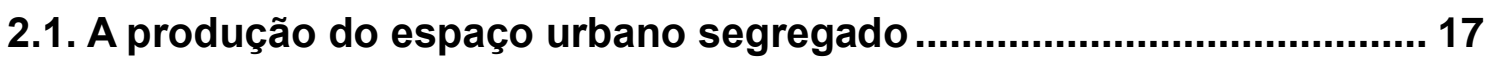

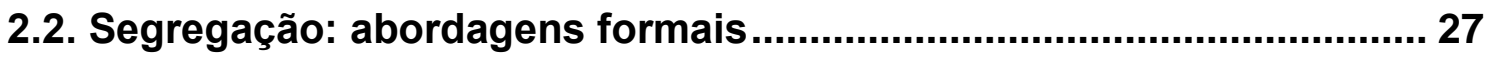

2.3. Segregação: abordagens conceituais ................................................. 29

2.4. Papel da HIS na produção do espaço segregado no Brasil ................ 48

2.5. MCMV: habitação, segregação e mercado .......................................... 59

3 APROPRIAÇÃO E DINÂMICAS SOCIOESPACIAIS.................................... 73

3.1. Crítica à arquitetura e urbanismo funcionalistas: apropriação do

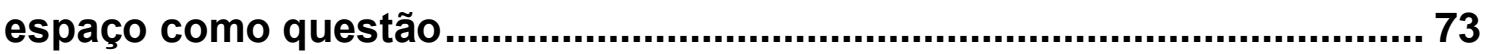

3.2. O cotidiano, a apropriação do espaço e o direito à cidade: uma

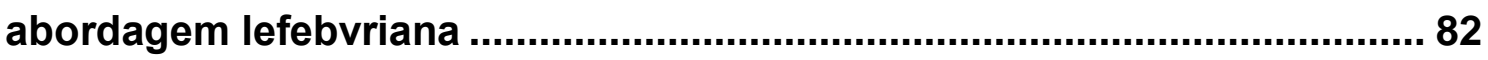

3.2.1. Dos Situacionistas a Lefebvre: crítica do cotidiano urbano............. 82

3.2.2. Crítica lefebvriana: o cotidiano alienado e a produção funcionalista

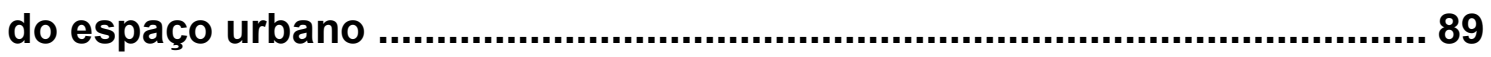

3.2.3. A apropriação do espaço como noção lefebvriana ........................... 96

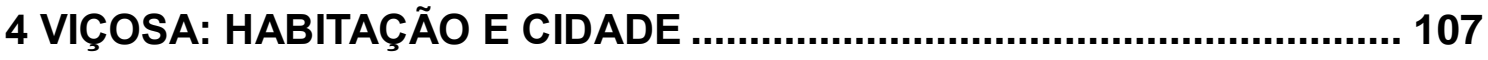

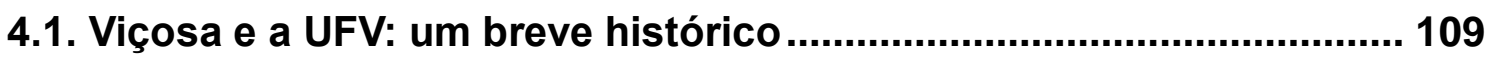

4.2. Mercado imobiliário e a produção do espaço segregado................... 115

4.3. Contexto imobiliário .............................................................................. 133

4.4. O Minha Casa Minha Vida em Viçosa ................................................ 142

4.5. Legislação e política para HIS em Viçosa ......................................... 150

5 TRAJETÓRIAS DE VIDA E APROPRIAÇÕES DOS ESPAÇOS PELOS MORADORES DOS CONJUNTOS EM VIÇOSA....................................... 159

5.1. Trajetórias de vida, dinâmicas socioespaciais e apropriações dos espaços em conjuntos do PMCMV em Viçosa-MG.................................... 161

5.2. A mudança para os conjuntos e os primeiros problemas ................. 171

5.3. Os espaços de lazer e as apropriações: desenho urbano, violência e

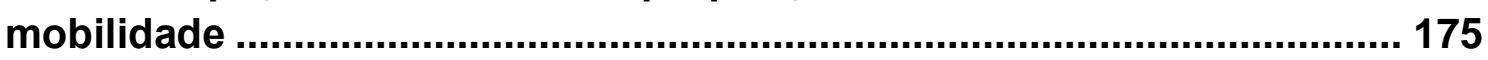

5.4. Violência como fator limitador de apropriações e da liberdade de ação

5.5. A casa própria como fator de permanência e a apropriação da moradia 
5.6. Alienação espacial: considerações sobre a produção do espaço social

5.7. A política habitacional do PMCMV e a cidadania pelo consumo: primeiras conclusões.................................................................................... 205

6 CONCLUSÕES .............................................................................. 209

6.1. Considerações para trabalhos futuros: apontamentos para uma abordagem da segregação em cidades médias .................................... 214

REFERÊNCIAS BIBLIOGRÁFICAS .................................................... 219

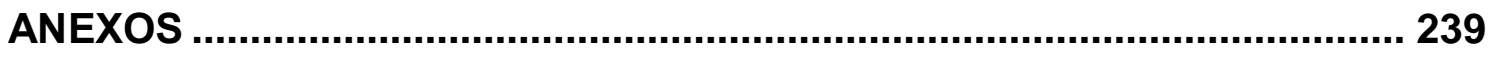

ANEXO I. Mapa de localização dos bairros na malha urbana .................. 240

ANEXO II. Mapa de localização dos conjuntos estudados na malha urbana

ANEXO III. Mapa de localização das principais áreas públicas de lazer . 242

ANEXO IV. Mapa de localização dos equipamentos públicos .................. 243

ANEXO V. Mapa de mobilidade .................................................................. 244

ANEXO V. Fotografias panorâmicas comparativas .................................. 245 


\section{INTRODUÇÃO}

Desde a revolução industrial o acesso à habitação vem sendo destaque nas discussões sobre cidade e sociedade, pois constitui-se como uma das chaves para entender e solucionar diversos problemas urbanos relacionados à inserção social e econômica de grupos sociais vulneráveis: o direito à moradia

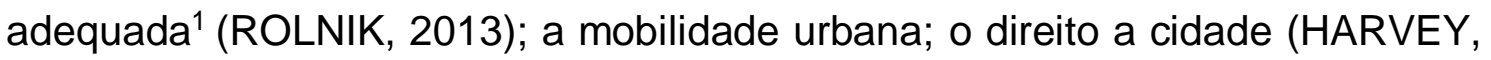
2014; LEFEBVRE, 2001)² e; o acesso à cidadania.

A evolução do pensamento crítico acerca da habitação, porém, não foi acompanhada pela melhoria no acesso e nas condições das habitações destinadas à população economicamente vulnerável. Isso porque a terra urbana e a urbanização são tratadas como mercadorias e estão diretamente relacionadas com a espoliação urbana. Isto pois "(...) no interior do regime capitalista em que vivemos, a casa, a habitação, é uma mercadoria como não importa qual outra, que é produzida tendo por objetivo a finalidade geral da produção capitalista, isto é, o lucro." (SINGER apud FERRO, 2006, p. 105). O problema da falta de acesso à habitação e o problema do acesso à cidade a partir da habitação são elementos centrais no entendimento do contexto social, portanto, não só no âmbito econômico, mas também no sentido da participação cidadã e da construção de uma vida na/em sociedade. Ademais, a imposição de limitações no acesso à terra está no cerne da constituição do sistema capitalista ${ }^{3}$.

1 Destacamos aqui os trabalhos da pesquisadora e relatora para o Direito à Moradia na ONU (2008-2014) Raquel Rolnik. Para Rolnik, então: "Para ser adequada, a moradia deve atender a vários requisitos, como a segurança da posse, a disponibilidade de serviços e infraestrutura, a boa localização, um custo geral acessível, (incluindo a prestação ou aluguel e a manutenção da casa), entre outros aspectos." Disponível em:<http://spressosp.com.br/2014/06/11/raquel-rolni-moradia-nao-se-resume-uma-casa-teto-eparedes/> Acessado em: 01/12/2015 ver mais em: <http://direitoamoradia.org/>

2 Os dois autores tratam do tema com algumas diferenças. Porém os dois são essenciais no entendimento do Direito à Cidade e maiores aprofundamentos estão sendo realizados na revisão bibliográfica da pesquisa.

${ }^{3}$ Refiro-me às Leis dos Cercamentos responsáveis pela privatização de terras antes comunais na Inglaterra do século XVIII. Constituem-se como marcos para a formação da classe operária para o início do período capitalista. 
A pobreza urbana está conectada com o fenômeno da urbanização (SANTOS, 2013), de forma que a falta ou precariedade de habitações, bem como sua periferização, são características intrínsecas a este fenômeno. Em determinados contextos, no entanto, os problemas relacionados à habitação (e à falta dela) geram consequências negativas para o próprio sistema econômico que os fez emergir. Exemplos desses problemas são claros na historiografia urbana, tais como i) o alastramento de doenças, principalmente as relacionadas à falta de salubridade e higiene; ii) o aumento do preço da força de trabalho; iii) o empobrecimento da imagem da cidade, quando a quantidade de pessoas em situação de pobreza extrema passa a ser um fator de desvalorização de terras urbanas; etc. Assim, o mesmo sistema que fomenta a exclusão e a desigualdade busca formas de amenizar os problemas citados, como, por exemplo, a adoção de medidas higienistas ${ }^{4}$ e/ou a criação de vilas operárias, como explica Bonduki (2014, p.20) ao listar possíveis explicações para a emergência dessas vilas:

[...] filantropia de empresários favoráveis à harmonia entre o capital e o trabalho; estratégia para atrair operários em um mercado de trabalho incipiente; forma de disciplinar o tempo livre dos operários, submetendo-os à ordem burguesa e mantendoos sob permanente controle; necessidades da própria produção.

A partir dos problemas relacionados ao acesso à moradia destaca-se, atualmente, o tema do "direito à cidade". O direito à cidade tem sido abordado nos estudos que buscam entender os modos de organização política e social das cidades (MARICATO, 1996). Esse tema relaciona-se com inúmeras dimensões da cidade (social, econômica, ambiental, cultural, urbana, etc.) que dentre seus processos de crescimento e desenvolvimento, excluem pessoas (MARICATO, 1996; ROLNIK, 2004; SANTOS, 2013).

No Brasil, sobretudo após a década de 1940, a urbanização ocorreu de maneira desigual impulsionada pela atuação do Estado e de setores economicamente fortes, que constituíram forças de exclusão das parcelas sociais de baixa renda, empurrando-as para as periferias urbanas e consolidando problemas estruturais na organização política e social do território

\footnotetext{
$4 \quad$ A exemplo da narrativa das ações de Pereira Passos no início do século XX no Rio de Janeiro, que foi uma série de medidas legislativas e de operações urbanas que visaram 0 desmantelamento de cortiços no centro da cidade obedecendo a uma "higienização" da cidade.
} 
(SANTOS, 2013). Esses elementos têm sido interpretados no âmbito da questão urbana brasileira, a partir dos principais problemas sociais do território: a habitação, o saneamento, a mobilidade urbana e transporte (MARICATO, 2001).

A habitação em geral, mas sobretudo a habitação de interesse social (HIS), tem se constituído, como tema central a partir do qual se descortina uma série de questões sobre a promoção do direito à cidade, tomando-se como pressuposto que o direito à habitação deve ser entendido como direito à "moradia adequada". Assim, a moradia passa a ser um eixo a partir do qual se tem acesso aos serviços e equipamentos públicos, e aos espaços de sociabilidade ligados ao trabalho, lazer, cultura e educação. Sendo assim, o déficit habitacional deve ser analisado em seus componentes quantitativos, referentes à demanda de unidades habitacionais, por motivos de habitação precária, por exemplo; e qualitativos, que são referentes à falta de qualidade da habitação, como a falta de unidade sanitária, por exemplo (CYMBALISTA, MOREIRA, 2006).

O Brasil tem histórico de ações governamentais que visaram combater os altos números do déficit habitacional ao mesmo tempo em que usou a promoção da habitação como forma de evitar ou dirimir crises econômicas (HARVEY, 2011; CUNHA, 2014). Emergem daí as políticas habitacionais como as ações centralizadas pelo Banco Nacional de Habitação (BNH) e o atual Programa Minha Casa, Minha Vida (PMCMV).

O PMCMV é objeto de estudo de inúmeros pesquisadores que procuram, primordialmente, entender o desenho político e financeiro do programa, tendo em vista sua complexidade e importância. Também vêm sendo estudadas as principais consequências do PMCMV para as cidades em que foi implementado. Pesquisadores de diferentes áreas do conhecimento destacam a baixa qualidade arquitetônica das moradias, a segregação espacial provocada pelos locais de implantação de grande parte dos empreendimentos, as relações mercadológicas que regem o programa, dentre outros aspectos. Estudos realizados por Cunha (2014); Amore, Shimbo, Rufino (2015) entre outros, têm discutido as relações entre os agentes políticos, os agentes sociais, as construtoras e o mercado financeiro. Outros estudos procuram avaliar 0 programa pelo viés da satisfação dos beneficiários, como o recente "Pesquisa 
de satisfação dos beneficiários do Programa Minha Casa Minha Vida" (SNH, Mcidades, IPEA, 2014)5. Esta pesquisa, ressalta-se, tem como resultado nos quesitos de "inserção urbana" e "vizinhança" dois dos piores indicadores, apontando já para a necessidade de se estudar os impactos dessa política para além do simples acesso à moradia que obedeça certos padrões de adequabilidade.

Mesmo os estudos que visam averiguar os níveis de satisfação dos moradores dos conjuntos do PMCMV utilizam metodologias quantitativas, o que pode gerar como resultado dados conflitantes, como um alto nível de satisfação dos moradores com o imóvel e o conjunto, acompanhado de desejos de mudança das famílias para outro local. Isso pode ser explicado pelo fato de os moradores partirem de realidades mais difíceis, como a insalubridade da habitação anterior, e desejarem um espaço de sua escolha, melhor localizado ou mais próximo de seu local de origem. Assim, aquele que tem como parâmetro uma realidade de baixa qualidade de habitação (ou até mesmo habitações que ofereciam risco à vida) demonstrará certa satisfação em encontrar alguma qualidade de moradia (SNH, Mcidades, IPEA, 2014). Somado a isso, tem-se a posse do imóvel, que garante certa segurança patrimonial. Então, o nível de satisfação aparece alto. Vemos que avaliações sobre a qualidade do ambiente construído, quando não acompanhadas de análises espaciais e sociais, podem ocultar alguns pontos de inflexão que pesquisas em políticas públicas devem fazer emergir, como as disparidades apontadas nas pesquisas supracitadas com relação, sobretudo, à inserção urbana e aos modos de vida dentro dos conjuntos.

Assim, apesar da grande qualidade e abrangência dos estudos, pouco tem se falado sobre as sociabilidades e da apropriação do espaço pelos moradores. Os empreendimentos destinados às camadas economicamente e socialmente mais vulneráveis (correspondente à Faixa $1^{6}$ do PMCMV) são espaços construídos e habitados e, independente de avaliações quantitativas

\footnotetext{
$5 \quad$ Cabe destacar que a pesquisa tem como metodologia a análise de grau de confirmação a partir de afirmações em questionário, o que pode (e de fato apresenta) contradições nos resultados. Além disso,

$6 \quad$ Faixa 1 da Fase 1 do PMCMV (2009): contempla famílias com rendimento mensal de até $R \$ 1600,00$, com origem de recursos do FAR (Fundo de Arrendamento Residencial).
} 
referentes ao nível de satisfação dos moradores, deve-se procurar entender e analisar os modos de vida, bem como a relação dos moradores com os espaços dos empreendimentos e com a cidade.

Depreende-se, portanto, que há uma lacuna do conhecimento pela perspectiva de que esses espaços são relacionados à totalidade da cidade: pouco se tem discutido o espaço público, onde se constroem relações sociais como espaço da coexistência dessas pessoas. Pouco se tem buscado compreender sobre como essas pessoas se apropriam desse lugar da coexistência e sobre qual é o significado desse espaço novo; afinal, como elas definem suas relações individuais e coletivas no cotidiano da vida urbana?

Outra lacuna encontrada é referente ao tamanho das cidades que abrigam os empreendimentos estudados. Essas são, em sua maioria, Regiões Metropolitanas (RM) ou cidades médias com grande porte populacional e extensa malha urbana. Poucos estudos se dedicam aos empreendimentos em cidades de pequeno porte populacional ${ }^{7}$. Esse é o caso de Viçosa ${ }^{8}$, no interior de Minas Gerais, cidade com de cerca de 72 mil habitantes (IBGE, 201099). Cidades como essa possuem características urbanas e sociais que podem apresentar grandes mudanças nas relações com os espaços comparando-se com cidades grandes. Características culturais e físicas da cidade mudam os parâmetros de análise sobre populações em cidades de pequeno porte em relação às de $\mathrm{RM}$, pois há uma outra relação entre os moradores e deles para com os espaços urbanos.

Essa pesquisa ganha contornos no sentido de entender a importância desses espaços. A condição dos mesmos não pode ser considerada somente no que tange às qualidades urbanísticas e arquitetônicas, ou ao desenho político do programa, ou, ainda, às pesquisas de opinião sobre a qualidade ou não do PMCMV. É preciso entender aspectos mais profundos, concernentes às relações

\footnotetext{
$7 \quad$ Aqui compreendidas como cidades de até 100 mil habitantes.

A cidade de Viçosa pode ser considerada uma "cidade média" visto seu papel de subcentro regional, com algumas características de cidades de população maior, como é o caso de seu alto alcance tecnológico, fator advindo da presença da UFV na cidade. Porém, segundo o IBGE, a cidade é de pequeno porte pelo seu número populacional (até 100 mil habitantes).

9 Disponível em: <http://censo2010.ibge.gov.br/>
} 
entre os sujeitos, os espaços de moradia, a cidade e seus significados. No sentido urbano e "do urbano" (da práxis, da sociabilidade, da vivência, etc.), quais são esses significados? Será que o acesso à moradia para essas pessoas desencadeia a construção de laços comunitários, de identidade, participação, apego ao lugar, etc.) ligados aos espaços (dos conjuntos e da cidade) e à comunidade?

O problema da pesquisa parte, então, da necessidade de entender 0 papel que o espaço urbano e a moradia desempenham no cotidiano da vida pública de famílias inseridas em novos espaços. Em cidades de pequeno porte, como podemos entender as relações dos pobres que saem do contexto da exclusão urbana para inclusão da moradia? O deslocamento dos espaços anteriores de moradia para conjuntos habitacionais possibilita quais experiências de apropriação do espaço urbano? Há construção de lugares em espaços da coexistência? Os moradores permanecem à mercê dos processos de exclusão do cotidiano da cidade?

De acordo com um estudo realizado para Prefeitura Municipal de Viçosa (PMV, 2014) a cidade registrou, em 2013, um déficit habitacional de 1780 domicílios para uma população total de 76.147 habitantes. Foram construídos, desde 2011, três conjuntos habitacionais atendendo 332 famílias das registradas em situação de vulnerabilidade de moradia. No contexto do acesso ao direito à moradia, o espaço urbano ganha sentido como ponto de partida para o entendimento do processo reinserção social.

Tendo em vista que os conjuntos do PMCMV em Viçosa possibilitam a exploração das duas lacunas científicas aqui levantadas, temos a definição do campo empírico e objeto de estudo da pesquisa: dois empreendimentos do PMCMV em Viçosa, Minas Gerais, destinados à Faixa 1 do Programa, habitados por famílias que viviam em contextos de precariedade ${ }^{10}$ das condições de moradia e/ou coabitação nesta cidade.

10 Entende-se, aqui, a precariedade de forma ampla. Contudo, a precariedade é um componente único de estudos e políticas públicas em habitação relacionado, geralmente, às condições construtivas da moradia. 
Nos cabe questionar: como é a relação entre os moradores e os espaços exteriores aos seus conjuntos? Dada a escala da cidade e o fato de os conjuntos serem locais de baixo movimento de automóveis, não seriam estes conjuntos habitacionais, sobretudo para crianças e idosos, locais com potencial para o reestabelecimento da rua como local do encontro e de práticas sociais? E ainda, a partir dessas práticas podemos identificar espaços de solidariedade, de identidade e de fortalecimento de um caráter político de um grupo social? Como se dá o processo de apropriação dos espaços? Há fatores que promovem ou dificultam a apropriação? Se existem, esses fatores são de ordem físico-espacial e/ou de ordem social?

A apropriação do espaço constitui-se, então, como eixo da pesquisa, pois é um processo de construção social. Esse processo vem ao encontro dessas questões levantadas e deve ser usada como ferramenta para a compreensão do complexo cenário urbano composto por um programa habitacional de tamanha importância.

A apropriação se dá através de condicionantes físicas (espaços), temporais (sociabilidades, usos dos espaços e suas temporalidades) e subjetivos (identificação, apego ao lugar). O processo de apropriação é variável de acordo com as características do sujeito ou grupo analisado. Deve-se analisar cada grupo tendo em vista sua heterogeneidade quanto às características culturais de origem, suas experiências, relações sociais, faixa etária, etc.

Como veremos, o espaço apropriado passa a ser considerado como um fator de continuidade e estabilidade do "sujeito", em conjunto com o fator de estabilidade e da identidade e coesão do grupo. Assim, a apropriação do espaço é um fator de avaliação da inserção no meio e na comunidade, dos usos dos espaços e suas potencialidades e do acesso à cidadania.

As condições das moradias que compõe o déficit habitacional podem ser observadas em diferentes fatores, tanto dos aspectos físicos da habitação quanto na qualidade de vida dos moradores. Dos físicos, podemos citar a insalubridade da habitação, construções improvisadas e os riscos relativos à segurança na habitação (localização em encostas, margens de cursos d'água, 
etc.). Quanto à qualidade de vida de seus moradores, podemos citar a coabitação forçada entre núcleos familiares, o adensamento excessivo da unidade (3 ou mais pessoas dividindo um quarto pequeno, por exemplo) e o comprometimento da renda familiar com aluguel. Além desses componentes, há ainda outras dificuldades comuns relativos à localização das moradias. Os principais são ${ }^{11}$ :

[...] dificuldade de acesso aos serviços e infraestruturas urbanos (transporte precário, saneamento deficiente, drenagem inexistente, dificuldade de abastecimento, difícil acesso aos serviços de saúde, educação, creches, maior exposição à ocorrência de enchentes e desmoronamentos, etc) somam-se menores oportunidades de emprego (particularmente o emprego formal), menores oportunidades de profissionalização, maior exposição à violência (marginal e policial), discriminação racial, discriminação contra mulheres e crianças, difícil acesso à justiça oficial, difícil acesso ao lazer. A lista é interminável. (Maricato, 2001, p. 4)

O fator da localização dos empreendimentos tem sido um dos principais alvos das críticas feitas por pesquisadores e agentes de organizações de luta por moradia. Como os empreendimentos visam, em primeiro lugar, a acessibilidade para a compra, ou seja, o preço das habitações, as localidades mais distantes dos centros são as melhores escolhas em busca de terrenos baratos para a implantação dos empreendimentos.

$\mathrm{Na}$ cidade de Viçosa a localização dos empreendimentos segue a mesma lógica da busca por terrenos baratos, estudada e verificada nas RMs, e, com isso, de ocupação em áreas de expansão da malha urbana. Há ainda a questão da expansão das terras urbanizadas, central para as cidades de pequeno e médio porte contempladas pelo PMCMV e não diferente em Viçosa. Essa expansão aumenta o valor de terrenos próximos ao levar até os mesmos uma infraestrutura básica. No caso de Viçosa é de suma importância para o setor imobiliário que haja essa expansão, tendo em vista a baixa disponibilidade de

11 A lista refere-se a alguns componentes que, na época, eram determinantes para caracterizar um contexto de "exclusão social". Atualmente, contudo, a participação do Estado na chamada "gestão da pobreza", principalmente, não nos permite falar em "exclusão social" propriamente, tendo em vista que as pessoas e territórios de pobreza estão hoje, de alguma forma, participantes das dinâmicas econômicas e sociais de uma cidade. O que não finda com os componentes citados, que persistem na realidade atual relativos à - má - localização das moradias. 
terrenos para novas construções, como veremos adiante. Porém, apesar de seguir as mesmas lógicas (comandado pelas elites locais e/ou grandes construtoras), a localização dos empreendimentos em Viçosa tem características próprias devido ao relevo natural e ao tamanho e adensamento da cidade.

Para a implantação dos empreendimentos estudados, foi escolhida uma área de fazendas na zona rural do município. O primeiro conjunto construído "herdou" seu nome popular: "Coelha". Os conjuntos estudados ficam próximos ao bairro Santa Clara, que tem por característica abarcar desde residências e edifícios voltados para a classe média e média-alta da cidade, quanto ocupações irregulares (algumas de classe média também) e residências voltadas às famílias de classe econômica baixa. A área escolhida, apesar de se encontrar próxima a um bairro e a distar apenas 3,5 quilômetros do centro da cidade (a partir da moradia mais distante e 1,6 km a partir da moradia mais próxima ao centro), apresenta-se segregada da malha urbana por uma barreira geográfica natural: um morro que teve sua encosta menos inclinada ocupada (voltada para o centro), enquanto a outra permanece desocupada, permanecendo uma faixa de terreno natural entre a malha urbana e a área de implantação dos empreendimentos. Tal barreira, por sua inclinação, dificulta a saída do bairro em direção ao centro pelos moradores que não possuem veículo motor ou aos com menor capacidade de locomoção, deixando-os a mercê do transporte público.

Após a implantação, os empreendimentos receberam os nomes de Conjunto Benjamim José Cardoso (BJC) e Conjunto César Santana Filho (CSF), em homenagem ao pai de um ex-prefeito e a um outro ex-prefeito da cidade. Foram construídas 132 e 123 casas em cada conjunto, respectivamente.

Obedecendo às diretrizes do PMCMV, a maior parte dos titulares são do sexo feminino, cerca de 93\% (GUIMARÃES, 2013), condizente também com a política pública de distribuição de renda Bolsa Família (Lei nº 10.836/2004), da qual cerca de $70 \%$ dos moradores são beneficiários ${ }^{12}$ (GUIMARÃES, 2013). Mesmo que todos os titulares das moradias pertençam à Faixa 1 do PMCMV, pode-se observar uma disparidade dentro do conjunto quanto aos bens que

$1270 \%$ no Conjunto Benjamim José Cardoso (BJC) e 71,4\% no Conjunto César Santana Filho (CSF) 
possuem e condições de trabalho e renda. Há famílias que dispõe de carro próprio, enquanto outras têm que usar o Bolsa Família como complemento de renda e até famílias que tem no apoio dado por este programa a maior parcela de rendimento mensal. Quanto à escolaridade há um predomínio, entre os titulares, de pessoas com ensino fundamental incompleto. No Conjunto CSF, que tem a maior taxa de escolaridade, apenas $14,3 \%$ dos titulares têm ensino médio completo (GUIMARÃES, 2013).

Atualmente, os conjuntos passam por um processo de ampliação de boa parte das casas, sobretudo no conjunto BJC, onde pode-se observar moradias com acréscimo de área com edificações "anexas" à original, todas erigidas por meio da autoconstrução, sendo algumas delas com até 2 pavimentos. A maior parte das casas conta com algum tipo de proteção do lote. As proteções vão desde cercas de bambu até a muros de alvenaria com altura superior a 2 metros, escondendo a edificação de quem a vê da rua. Apesar de não haver grande incidência de furtos e roubos nos conjuntos, há presença do tráfico de drogas e um clima geral de desconfiança em relação aos vizinhos e, principalmente, em relação aos moradores dos bairros próximos.

Tem-se, então, como objetivo geral da pesquisa, entender as formas de apropriação do espaço urbano pelos moradores dos dois conjuntos habitacionais do Programa Minha Casa, Minha Vida na cidade de Viçosa, MG e compreender os fatores geradores de espaços de segregação. Como objetivos específicos, tem-se o entendimento do processo histórico de produção do espaço e da segregação desenvolvidos na cidade de Viçosa; a compreensão e análise da segregação como conceito e seus fatores; a compreensão do conceito de apropriação em suas diferentes abordagens.

Como proposta metodológica tem-se a pesquisa qualitativa. Compreende-se que as metodologias qualitativas, dentro do campo das Ciências Sociais Aplicadas, permitem um melhor arranjo nos procedimentos de pesquisa, pois estes podem ser combinados de forma a se adequarem melhor à proposta de investigação. Por tratar-se de uma investigação de abrangência territorial pequena (pequenos empreendimentos em uma cidade de porte populacional pequeno), e tendo em vista a busca por especificidades que só podem ser 
compreendidas quando vistas de forma mais profunda e particularizadas, temse nos métodos de estudo relativos às pesquisas qualitativas as melhores possibilidades de aprofundamento no objeto de pesquisa. "Parece-nos que os métodos quantitativos (a matemática da quantidade, claramente distinta daquela da qualidade) não apreendem senão realidades estáticas, fixas ou consideradas como fixas", portanto, nunca um movimento (LEFEBVRE, 1971, p. 13), algo essencial para o presente estudo.

Para a coleta dos dados qualitativos, o presente trabalho fez pesquisa teórica, documental e empírica, e com a análise de entrevistas semiestruturadas. Escolheu-se dentre as alternativas a de entrevistas semiestruturadas buscando uma maior liberdade de fala dos sujeitos e, possivelmente, uma maior pessoalidade e riqueza de informações. Visto que "roteiros altamente estruturados e de questões fechadas truncam o discurso do sujeito e ainda que permitindo, às vezes, uma análise quantitativo-interpretativa, a tornam difícil e podem mesmo enviesá-la." (ALVES, SILVA, 1992, p. 64). Ou ainda, nas palavras de Lefebvre: "somente a entrevista não dirigida pode captar o habitar." (LEFEBVRE, 1971, p. 160, grifos meus, tradução minha).

Como sugerem Alves e Silva (1992, p. 63), a construção do roteiro de entrevista procurou dividi-la em "núcleos de interesse do pesquisador", propondo uma direção na coleta de dados e auxiliando na organização e análise dos dados coletados nas entrevistas, mesmo que essas abram espaço para que 0 entrevistado percorra por assuntos que não estavam inicialmente propostos. A intenção em criar os núcleos dentro da entrevista semiestruturada foi tentar conduzir o entrevistado pelos eixos temáticos relevantes já determinados na estruturação teórica da pesquisa. Segundo André (1983) esta visa apreender o caráter multidimensional dos fenômenos em sua manifestação natural, bem como captar os diferentes significados de uma experiência vivida, auxiliando a compreensão do indivíduo no seu contexto.

Esse tipo de coleta de dados coloca a necessidade de o pesquisador fazer o que Mettel (apud ALVES, SILVA, 1988) define como sendo o "bom uso da tecnologia" o que significou, nesse caso, lançar mão do recurso "gravação", visando "evitar o seu comprometimento" dos discursos, além de permitir ao 
entrevistador maior liberdade para interagir com o entrevistado. Desta forma, optou-se pela aplicação de entrevistas abertas e semiestruturadas e observações de campo como principais métodos de pesquisa de fonte primária.

A partir do referencial teórico estudado, teremos, então, como indicadores de sociabilidades e apropriações: usos recorrentes dos espaços públicos por famílias ou outros coletivos (mesmo que pequenos); promoção e participação em eventos e encontros; organizações dos moradores em dimensões culturais (religião, por exemplo), sociais (grupos de apoio, por exemplo) e políticas (associações, reivindicações, participação interna e externa ao conjunto, etc.); modificações de espaços dos conjuntos promovidos pelos moradores; relações de sociabilidade por proximidade física ou por outro fator; abertura de possibilidades à novas apropriações por espaços de uso coletivo acessíveis e adequados.

Cabe adiantar que modificações e demarcações internas aos imóveis serão consideradas a fim de estabelecer com maior clareza os lugares e dimensões sociais alcançadas pelos moradores em suas apropriações. A ressalva se faz necessária pois nos capítulos de revisão teórica há uma abordagem política e coletiva sobre as apropriações, o que contrasta com a incidência e importância das apropriações internas (individuais e familiares) para os entrevistados, sendo este um indicador das limitações e da individualização da dimensão social encontrada na análise das entrevistas e dos conjuntos.

Há, anterior e concomitantemente às entrevistas e levantamento de campo, a consulta a fontes secundárias com objetivo de maior embasamento crítico-teórico e aprimoramento das consultas às fontes primárias. A consulta a mapas e outras formas de leitura dos territórios também foram utilizadas para melhor delimitação tanto do objeto de pesquisa, quanto das informações obtidas com as fontes primárias. Foi realizada pesquisa em bibliografia especializada, levantamento de informações sobre os locais a serem visitados, e análise dos espaços públicos, com visitas in loco. Para esta última, foi realizado levantamento fotográfico, e aplicação de instrumentos para coletas de dados: roteiros de observação, e questionários e entrevistas. 
O processo de levantamento de dados foi dividido em duas etapas: um primeiro conjunto de visitas a campo para observações preliminares e realização de contatos com possíveis entrevistados e um primeiro levantamento fotográfico com anotações em caderno de campo, realizada entre novembro e dezembro de 2015; um segundo conjunto de visitas, com levantamento fotográfico e anotações em caderno, desta vez também com a realização de entrevistas, realizadas entre julho e agosto de 2016.

Foram abordadas cerca de 10 famílias, das quais 7 se prontificaram a responder as perguntas do estudo. Dessas, apenas uma casa não foi visitada, devido aos horários de trabalho dos moradores. Dessa forma, seis casas foram visitadas nos dois conjuntos. Uma delas em situação especial, pois se tratava de uma residência ocupada ${ }^{13}$.

Como produtos, além do texto da dissertação, tem-se:

1) Mapa de localização dos bairros na malha urbana de Viçosa: este mapa pretende auxiliar na leitura da malha urbana da cidade, situando os bairros, localizando os acessos à cidade, e pontuando os bairros em estudo em relação aos demais.

2) Mapa de localização dos conjuntos habitacionais na malha urbana: este mapa tem o intuito de situar os dois conjuntos habitacionais em relação à malha urbana da cidade, destacando os acessos formais ao bairro e a distância linear até o centro da cidade.

3) Mapa de localização dos equipamentos públicos: este mapa apresenta os principais equipamentos públicos nas proximidades dos conjuntos habitacionais estudados.

4) Mapa de mobilidade: este mapa apresenta o trajeto da linha de ônibus que atende os conjuntos habitacionais estudados, o tipo de pavimentação dos acessos ao bairro e do calçamento do bairro, e os pontos de ônibus.

\footnotetext{
13 A titular abandonou a casa e a família entrevistada, sabendo do abandono, passou a residir.
} 
5) Mapa de localização das principais áreas públicas de lazer: este mapa mostra as principais praças e equipamentos públicos de lazer disponíveis nas proximidades dos conjuntos habitacionais estudados.

6) Transcrição literal das entrevistas.

7) Fotografias.

Este texto está dividido por capítulos. No atual capítulo introduzimos a temática tratada, sua justificativa, as metodologias e objetivos propostos pelo trabalho. Para o segundo capítulo, chamado "Segregação socioespacial", tratamos de realizar uma revisão bibliográfica sobre as abordagens conceituais de segregação, procurando aprofundarmos em estudos marxistas que tratam sobre o tema e sobre a produção do espaço. Ao final do capítulo, buscamos relacionar o Estado em seu papel na produção do espaço e da segregação por meio das políticas habitacionais de maior impacto no Brasil. Espera-se que o capítulo instrumentalize as compreensões tratadas no capítulo seguinte.

O terceiro capítulo trata sobre a apropriação e suas abordagens históricas. Procuramos demonstrar um caminho histórico para as compreensões sobre as apropriações a partir do campo de estudo e atuação de arquitetos e urbanistas, grandes interessados nos processos de apropriação dos espaços projetados, arquitetônicos e urbanísticos. Ao final do capítulo, descrevemos a compreensão lefebvriana a partir de uma revisão bibliográfica de seus textos mais conhecidos que tratam da apropriação. Buscamos demonstrar, então, as raízes marxistas da compreensão lefebvriana, conectando o conteúdo do capítulo ao conteúdo abordado no capítulo anterior.

No quarto capítulo chamado "Viçosa: Habitação e cidade", buscamos tratar sobre a produção do espaço urbano em Viçosa, MG, procurando demonstrar os principais agentes produtores do espaço e o processo histórico de expansão da malha urbana e de segregação de parte da população das áreas centrais da cidade. Apontamos também para a construção legislativa das últimas décadas e seus descompassos com relação à Habitação de Interesse Social na cidade, assinalando para a ineficiência e/ou complacência histórica do poder legislativo local para com a legislação urbanística. 
Para o capítulo cinco, procuramos demonstrar as trajetórias de vida de moradores de conjuntos habitacionais construídos através do Programa Minha Casa, Minha Vida em Viçosa, MG. Ademais, expusemos também algumas análises das apropriações (e da falta delas) nos espaços públicos dos conjuntos, apontando para os principais fatores limitadores para as apropriações e ressaltando a importância do espaço privado para as famílias. Ao final, temos algumas considerações sobre o processo de implementação do Programa na cidade e sobre a política habitacional desenvolvida pelo MCMV de modo geral.

No sexto e último capítulo, demonstramos as conclusões sobre o trabalho e sobre o programa habitacional, de forma geral. Apontamos também para a alienação e segregação dos espaços produzidos pelo Estado para a população economicamente mais pobre e vulnerável, limitando as possibilidades de usos, apropriações e de inserção social para essa população. Assinalamos, ao final, para lacunas que podem ser tratadas em estudos futuros e que foram paralelamente delineadas durante todo o estudo, apontando para a necessidade de maiores estudos específicos para cidades de porte pequeno a médio no que tange a produção do espaço segregado. 


\section{SEGREGAÇÃo SOCIOESPACIAL}

Os processos de segregação socioespacial foram amplamente estudados em diferentes realidades urbanas. A segregação é uma realidade global presente nas grandes cidades. Há, claro, diferenças fundamentais quanto aos tipos de segregação de acordo com os processos históricos, econômicos e sociais passados pelos países. Contudo, busca-se, além das compreensões das diferentes realidades, os mecanismos comuns que levam as sociedades - e cidades - a apresentarem territórios e suas populações segregadas.

A segregação socioespacial deve ser entendida através dos mecanismos de produção do espaço e da produção de localização, bem como através do papel do Estado na produção de espaços segregados, com as políticas habitacionais tomando centralidade na questão da segregação (ROLNIK, 2015; LEFEBVRE, 1971; CORREA, 1989). Contudo, a segregação deve ser entendida também como um controle sobre os espaços e, consequentemente, como instrumento de controle dos corpos nos espaços (LEFEBVRE, 2013). Compreende-se também que a segregação está diretamente ligada ao sistema de política econômica adotado e que no capitalismo - como sistema de apropriação individual do trabalho coletivo e de produção de raridades (monopólios) - a segregação é um problema inerente ${ }^{14}$.

Pretende-se aqui, para tanto, abordar a produção do espaço e a segregação através de perspectivas de autores marxistas ${ }^{15}$ sobretudo (mas não

\footnotetext{
${ }^{14}$ A segregação de modo geral não pode ser vista como exclusividade das sociedades capitalistas. Historicamente, como aponta Marcuse (2004), há a diferenciação social no espaço com divisões muitas vezes claras entre parcelas das sociedades. Esteve e está presente também nos países comunistas e socialistas. Como nos apontou Lefebvre (1999; 2013), a fragmentação e funcionalismo ideológicos no processo de produção dos espaços leva, consequentemente, a uma cidade de característica hierarquizada e alienada aos seus moradores, em menor ou maior grau, independente da corrente da política econômica vigente. Ainda segundo Lefebvre (1971), cada sociedade tem um modo de produção e, consequentemente, uma forma de produção de espaço com territórios dominantes em detrimento de outros. Não está no nosso escopo, contudo, descrever ou analisar a segregação em países e cidades não-capitalistas.

${ }^{15}$ Pesquisadores cujos trabalhos têm inspiração nos escritos de Karl Marx (1818-1883), filósofo alemão que escreveu "O Capital", coleção de textos sobre economia política publicados a partir
} 
exclusivamente), no entendimento de que essas perspectivas são as que melhor explicam o espaço enquanto "produto" social, o que será relacionado com as compreensões amplas sobre o trabalho, que nos leva mais próximos de nosso tema central, a apropriação dos espaços, tendo em vista que esse é um elemento fundamental para o espaço urbano como obra, no sentido lefebvriano. Este caminho teórico se faz importante tendo em vista nosso campo de estudo, os conjuntos habitacionais do bairro São Francisco de Assis em Viçosa, MG.

Outro fator basilar que nos leva a uma leitura por meio de autores de inspiração em Marx é que a segregação é uma expressão tanto da divisão social do trabalho quanto da divisão de classes, o que nos indica que a segregação não deve ser analisada de forma apenas paralela em relação à luta de classes e suas consequentes e permanentes disputas territoriais.

Cinco fatores são, portanto, fundamentais no entendimento amplo do espaço urbano: i) ele é produzido, produto do trabalho humano coletivo; ii) o espaço urbano como trabalho tem dimensão social e cultural de valor de uso e valor de troca; iii) é um produto com apropriação diferencial por cada grupo/classe social; iv) o "produto produzido" vai além do espaço em si, mas é também a localização (VILLAÇA, 2015) e; v) o espaço urbano não se encerra em si mesmo, não sendo estático, mas relaciona-se com o tempo e é produto e produtor de uma sociedade e sua historicidade (LEFEBVRE, 2013).

\subsection{A produção do espaço urbano segregado}

A cidade é o produto do trabalho social humano (VILLAÇA, 2015) sobreposto em camadas históricas de diferentes categorias, com maior ou menor sedimentação (LEFEBVRE, 2013, p.), e que tem como objetivo maior, de modo geral, a reunião de pessoas, coisas e atividades (NETTO, 2013). Entender a cidade como produto, fruto do trabalho, é essencial na compreensão do papel da cidade na produção e reprodução do capital e da sociedade. Segundo Villaça

de 1867. Têm-se o entendimento de que o termo se refira também aos pesquisadores dos trabalhos do teórico Friedrich Engels (1820-1895), tendo em vista a sua proximidade e parceria com Marx. Os marxistas podem ser divididos entre ortodoxos e não-ortodoxos. 
(2015), o trabalho para a produção do espaço está além da reprodução da força de trabalho. Partiremos, então, da categoria trabalho - de modo apenas a construir uma base para o desenvolvimento do trabalho - e o retomaremos no capítulo seguinte.

Pode-se entender o trabalho de forma ampla, como a modificação de um elemento em outro através do esforço humano físico e intelectual, comumente expresso pela luta do homem sobre o domínio da natureza. Segundo Engels, "O trabalho, porém, é muitíssimo mais do que isso. É a condição básica e fundamental de toda a vida humana. E em tal grau que, até certo ponto, podemos afirmar que o trabalho criou o próprio homem" (ENGELS, 1876 ${ }^{16}$ ). Em seu texto, apesar de não terminado, Engels (1876) explana como os símios mais aptos ao trabalho foram selecionados naturalmente - tendo como base a teoria de Darwin - pois conseguiram um consumo mais rico de alimentos e puderam se adaptar aos diferentes meios através da modificação da natureza em ferramentas de sobrevivência.

Outros animais também modificam a natureza para sua sobrevivência, mas cabe ressaltar que apenas o ser humano modifica a natureza de forma previamente pensada e para satisfazer necessidades socialmente determinadas, até mesmo independentemente de suas necessidades físicas. "(...) na verdade, o homem só produz verdadeiramente quando está livre da necessidade física" (DUARTE, POLA, 2009, s/p). Com isso podemos inferir que a própria produção determina o tipo de trabalho que deve ser realizado e o tipo de sociedade existente. Dessa forma, o trabalho socialmente determinado é também determinante:

Enquanto o homem existir ele terá que dedicar parte do tempo da sociedade para se apropriar dos objetos da natureza e de transforma-los em objetos de uso humano através do trabalho. Essa é uma necessidade insuprimível da realidade humana. No entanto, é importante observar que se é verdade que o homem jamais poderá deixar de se apropriar dos objetos da natureza por intermédio do trabalho, o modo como ele realiza essa apropriação é historicamente cambiante. A compreensão do

${ }^{16}$ Disponível em: <https://www.marxists.org/portugues/marx/1876/mes/macaco.htm> Acesso: 12 dez 2017. 
modo como os homens se apropriam e transformam a natureza está indissociavelmente ligado às formas como os homens se relacionam entre si e ao desenvolvimento das forças produtivas da sociedade. (GOMEZ apud DUARTE \& POLA, 2009, s/p).

Observa-se, então, que há uma dimensão social e cultural na categoria trabalho. Assim, o trabalho deve ser visto em sua dimensão, ao mesmo tempo ontológica e histórica ${ }^{17}$. Nas palavras de Marx (2017, p. 255), "Pressupomos o trabalho numa forma em que ele diz respeito unicamente ao homem". O trabalho enquanto capacidade de intervir e adaptar objetos às necessidades e vontades dos homens modificaram as formas de viver dos homens de tal maneira que 0 trabalho está no cerne do que nos faz humanos:

O processo de trabalho (...) é atividade orientada a um fim - a produção de valores de uso -, apropriação do elemento natural para a satisfação de necessidades humanas, condição universal do metabolismo entre homem e natureza, perpétua condição natural da vida humana e, por conseguinte, independente de qualquer forma particular dessa vida, ou melhor, comum a todas as suas formas sociais (MARX, 2017, p. 261)

Há, ainda, uma segunda dimensão do trabalho, prática, do trabalho enquanto força de trabalho a partir do qual há o direcionamento da força transformadora à mera mecânica incorporada ao seu objeto, "objetivado" (MARX, 2017, p. 258), gerando um produto com algum valor de uso (mercadoria). Essa força transformadora passa a ser utilizada para a produção, sem que o objeto (ou conhecimento) produzido objetive o viver ou esteja condizente necessariamente com as vontades do trabalhador. Não que o objeto seja diferente, mas sim o seu modo de produção com relação ao trabalho livre e espontâneo do trabalhador guarda duas dimensões expressas na mercadoria. Para Marx:

uma coisa simples escapou aos economistas sem exceção, é que, se a mercadoria tem o duplo (caráter) de valor de uso e de valor de troca, o trabalho apresentado na mercadoria deve possuir também duplo caráter, enquanto que a simples análise do trabalho sem frase como em Smith, Ricardo etc. se choca

\footnotetext{
17 Cabe ressaltar que a dimensão ontológica do trabalho já havia sido apontada por Marx em seus primeiros escritos, conhecidos como "Grundrisse". (MARX, Karl. Grundrisse: manuscritos econômicos de 1857-1858: esboços da crítica da economia política. São Paulo: Boitempo Editorial, 2015.)
} 
sempre com coisas inexplicáveis. Este é na realidade todo o segredo da concepção crítica ${ }^{18}$

Este trabalho é o trabalho abstrato.

O trabalhador na posição de força produtiva faz apenas o que "deve" ser feito, alienando-se do produto resultado de seu trabalho. Segundo Marx (2017, p. 266): "Durante o processo de trabalho, este passa constantemente da forma da agitação [Unruhe] à forma do ser, da forma do movimento para a da objetividade". Os objetivos são: no caso do trabalhador, a sobrevivência, tendo em vista que só há massa de trabalhadores pois não há alternativas outras de sobrevivência fora a venda de sua força de trabalho; no caso do capitalista, a transformação do trabalho em mercadoria com valor de uso cristalizado e valor de troca, obtendo o mais valor (MARX, 2017).

O trabalho, portanto, não necessariamente está voltado à produção de um produto com valor de troca, mas pode ser também a condição pela qual os homens modificam seu meio e o tornam mais adequado a si e a seu grupo, dotando-o ou utilizando-se de seu valor de uso. O trabalho subsumido para a geração do mais valor, por sua vez, tem características de mercadoria e pertence à esfera do valor de troca. Para o espaço urbano e o urbano Lefebvre (2001. p. 31) afirma que: “(...) a oposição entre o valor de uso (a cidade e a vida urbana, o tempo urbano) e o valor de troca (os espaços comprados e vendidos, o consumo de produtos, dos bens, dos lugares e dos signos) surgirá em plena luz"

Seguiremos, enfim, à produção do espaço. Não nos aplicaremos a uma revisão bibliográfica ou mesmo procuraremos extenuar o tema. Contudo, faz-se necessário percorrer este caminho para chegarmos à segregação e à apropriação, temas importantes em nossa pesquisa. Cabe ressaltar que o termo "produção do espaço" foi popularizado por Lefebvre e tem sido utilizado desde então em estudos de diversos campos do saber, como a Geografia, a Arquitetura, o Urbanismo, a Sociologia, a Economia e etc, dado a sua

\footnotetext{
${ }^{18}$ Ver: Marx, K. Capítulo VI Inédito de O Capital - Resultados do Processo de Produção Imediata. São Paulo: Editora Moraes, p. 59 e 61, apud K. Eduardo F. Chagas, A DETERMINAÇÃO DÚPLA DO TRABALHO EM MARX: TRABALHO CONCRETO E TRABALHO ABSTRATO. Disponível em: <https://marxismo21.org/wp-content/uploads/2012/08/A-determina\%C3\%A7\%C3\%A3odupla...-Ed.-Chagas.pdf> Acessado em: 10 de jan. 2018.
} 
centralidade na compreensão dos modos de produção do capitalismo em sua fase mais avançada. Contudo, a produção do espaço “(...) tem sido citada com tanta frequência que seu significado tem se desgastado, não sendo mais possível reconhecê-lo" (SCHMID, 2012, p. 90)

Dessa forma, cabe aqui realizarmos o exercício de explorar o tema, mas ressaltando que o próprio Lefebvre tem como prática científica-metodológica não fechar conceitos, deixando-os abertos às reinterpretações necessárias aos usos em diferentes contextos históricos, e também abertos a serem trabalhados com profundidade cada vez maior, favorecendo o acúmulo do conhecimento ${ }^{19}$. Como frisado pela geógrafa Ana Fani, Lefebvre nos dá "noções" com as quais trabalhar. Cabe ressaltar, antes de prosseguirmos, que essa compreensão é inerente ao método materialista dialético marxista apropriado por Lefebvre, como bem frisa Schmid (2012).

Lefebvre, em seus textos, observa a cidade no modo de produção capitalista, mostrando os papéis desempenhados pelo espaço urbano (social) em diferentes dimensões na reprodução desse sistema político e econômico. Para o autor:

O espaço se inscreve em sua totalidade no modo de produção capitalista modernizado: se utiliza para a produção do mais valor. A terra, o subsolo, o ar e a luz se incorporam às forças produtivas e aos produtos. O tecido urbano constituído por múltiplas redes de comunicação e intercâmbio forma parte dos meios de produção" (LEFEBVRE, 2013, p. 380, tradução nossa)

Passando para o contexto urbano, tanto o trabalho quanto o espaço passam a pertencer também à dimensão das mercadorias, sendo ao mesmo tempo produtos e objetos de consumos. Como afirma Lefebvre (2013, p. 376, tradução nossa):

O "mundo da mercadoria" não pode existir por si mesmo. Para existir, ele precisa de um trabalho. Para existir, necessita um trabalho. A mercadoria resulta de uma atividade produtiva. Toda mercadoria é um produto (de uma divisão do trabalho, de uma técnica, de um gasto de energia, em suma, de uma força de produção). Neste sentido, o conceito exige uma espacialização

\footnotetext{
${ }^{19}$ Ao falar sobre o conceito de "espaço", Lefebvre (2013, p. 55) cita Hegel para mostrar que "um conceito não aparece se não quando o que ele designa se vê ameaçado e se aproxima de seu fim e da sua transformação"
} 
para alcançar o concreto. A mercadoria necessita também do espaço.

Lefebvre (2013), então, procura analisar a terra (e a terra urbana) nos estudos de produção do mais valor e, em certo ponto de sua obra, tenciona sobre o esquema de leitura da economia política proposto em Marx. Segundo Lefebvre, Marx não se aprofundou em um elemento chave na compreensão da economia política, qual seja, a terra. Para o autor francês:

(...) Marx propôs um esquema ternário, segundo o qual no modo de produção capitalista e na sociedade existiam três elementos e não dois, três aspectos ou fatores a considerar: a terra (a Senhora Terra), o Capital (o Senhor Capital) e o trabalho (os Trabalhadores). Dito de outro modo: as rendas, o lucro e o salário (LEFEBVRE, 2013, p. 359-360, tradução nossa)

Dessa maneira, Lefebvre (2013) nos mostra que o trabalho enquanto valor de troca cristaliza-se juntamente com os objetos produzidos no espaço como capital constante 20 : "A atividade passada se cristaliza e torna-se condição da nova atividade" (LEFEBVRE, 2013, p. 381). No sistema capitalista, o espaço acaba por ser também um instrumento na produção que se dá, de todo modo, na produção do mais valor.

Ainda segundo Lefebvre, mesmo o ar, o solo ou o subsolo são incorporados às forças produtivas, pois fazem parte da totalidade do espaço que, inseridos no modo de produção capitalista, constituem-se em instrumentos para a produção do mais-valor (LEFEBVRE, 2013, p. 380). Para Lefebvre: "Não somente o capitalismo se apoderou do espaço pré-existente, da Terra, mas ele tende a produzir o espaço, o seu. Isso se dá por e através da urbanização (...)" (LEFEBVRE, 2013, p. 360, tradução nossa)

O espaço urbano, assim, pode ser visto como um meio para a apropriação do mais valor pelo Capital, como uma máquina para uma fábrica. Da mesma forma, seguindo este raciocínio da máquina fabril, Lefebvre (2013) demonstra que o capital constante passa a ser instrumento do mais valor quando é a ele adicionado trabalho. Ou seja, a máquina parada contém e entretanto não produz

${ }^{20}$ Capital constante é, segundo Marx, "(...) a parte do capital que se converte em meios de produção, isto é, em matérias-primas, matérias auxiliares e meios de trabalho, [e que] não altera sua grandeza de valor no processo de produção" (MARX, 2017, p. 286) 
valor, e pode perecer com a ação do tempo e das intempéries. Da mesma forma a cidade e o espaço urbano, enquanto instrumentos de organização das forças produtivas e dos tempos, quando não utilizada, torna-se capital morto, inerte. É preciso reanima-lo, torna-lo novamente em instrumento da extração do mais valor. Segundo Lefebvre: "A cidade e seus diferentes estabelecimentos (correios, estações ferroviárias, depósitos, entrepostos, transportes e serviços diversos) constituem capital constante" (LEFEBVRE, 2013, p. 380, tradução nossa) O espaço urbano, então, ao mesmo tempo, é fruto do trabalho; é sedimentação de camadas de trabalho (historicidade); é capital constante, instrumento para a extração do mais valor; é produto a ser consumido e está em constante (re)produção.

O espaço como produto deve ser fragmentado, dividido em partes para ser vendido. As partes mais caras são as de maior raridade, aquelas que detém monopólio sobre o valor de uso de sua localização (VILLAÇA, 2015). Estas constituem-se, sobretudo, quanto mais próximas às centralidades (ainda que hoje as melhores localizações urbanas, estejam alterando as noções tradicionais de centralidades e periferias). Como sistema que cria monopólios, os espaços produzidos enquanto produtos voltados à extração do mais valor e ao domínio territorial monopolista (ou o mais próximo disso) tem na centralidade uma forma de criar escassez do espaço. A centralidade enquanto escassez, por sua vez, geradora de disputa pelos espaços inserida na luta de classes que, é caracterizada por um movimento dialético. Segundo Lefebvre, “(...) a centralidade deste tipo expulsa os elementos periféricos com uma violência inerente ao espaço mesmo" (LEFEBVRE, 2013, p. 367)

O espaço urbano, segundo Lefebvre, portanto, "Está literalmente pulverizado; se vende em lotes e em parcelas. É assim como o espaço se converte em meio para as segregações, para a dispersão dos elementos da sociedade repelidos até as periferias" (LEFEBVRE, 2013, p. 368). Entendemos a partir de então o papel da produção do espaço na produção do espaço segregado. Está inserido no modo de produção e consumo capitalista. O espaço como mercadoria tem acesso e consumo limitados àqueles que detém poder na forma dinheiro o suficiente para gozar desses espaços nos quais há o acúmulo 
de trabalho e que se constituam como monopólios. Cabe frisar que o espaço não é somente produto para consumo, mas também influencia na sua própria produção e na produção capitalista. Cabe a nós perguntar, então, como e por quem este espaço é produzido?

O espaço visto dessa forma organiza a sociedade. E reside aí uma crítica central de Lefebvre: o espaço é produzido a partir de uma lógica racionalista, funcionalista, cartesiana, instrumental ${ }^{21}$, enfim, sob uma lógica que despreza 0 espaço enquanto totalidade nas dimensões que produzem, alteram e reproduzem o espaço social. Destarte, segundo Lefebvre em sua teoria da produção do espaço (social), este é composto e produzido dialeticamente em três dimensões, pois o espaço é percebido, concebido e vivido (LEFEBVRE, 2013, p.98); e essas três dimensões constituem-se em "processos ativos individuais e sociais ao mesmo tempo" (SCHMID, 2012, sp).

O espaço é percebido na medida em que é motivo de percepções por parte de seus usuários em seus sentidos: audição, olfato, visão, tato, paladar. Os usuários percebem os signos, fragmentações, reduções, códigos, proibições e imposições determinadas pelo conjunto dos elementos que compõe os espaços. Emerge, então, que o ordenamento territorial pretensamente racionalista é também uma ordem de uso dos espaços. Ao lembrarmos das implicações do urbanismo modernista, de inspiração corbusiana, sobretudo (tais como a hierarquização, o zoneamento, a funcionalização, os projetos concebidos sob "tábula rasa", e etc.), podemos inferir de antemão o posicionamento crítico de Lefebvre com relação à esta prática urbanística (trataremos mais no capítulo seguinte). Ademais, "O espaço de uma ordem se oculta na ordem do espaço" (LEFEBVRE, 2013, p. 325).

Assim, a produção do espaço a partir desse tipo de lógica resulta em espaços urbanos (concebidos) esvaziados - ou pretensamente "esvaziadores" - de suas outras dimensões: o percebido e o vivido. A dimensão do concebido é o espaço abstrato, ou "espaços de representação" que foram, então, planejados, pensados e materializados a partir das determinações históricas produtivas e

${ }^{21}$ Todos esses adjetivos são utilizados em textos de Lefebvre. 
sociais de seu tempo, sedimentados sobre outras camadas históricas. Segundo Lefebvre, o espaço concebido é, portanto, aquele espaço dos "cientistas, planejadores, urbanistas, tecnocratas fragmentadores, engenheiros sociais", e é o "espaço dominante em qualquer sociedade (o modo de produção)" (LEFEBVRE, 2013, p. 97, tradução nossa)

Penetrado por um saber, "uma mescla de conhecimento e ideologia" eficazes, os espaços concebidos são suscetíveis à prática social e política (LEFEBVRE, 2013, p. 100, tradução nossa): "O mesmo espaço abstrato pode buscar o lucro, privilegiar certos lugares organizando sua hierarquia, estipular a segregação (para uns) e a integração (para outros). As estratégias têm diversos alvos, focando determinados objetos, segundo seus recursos e objetivos" (LEFEBVRE, 2013, p. 325, tradução e grifos nossos)

A dimensão do vivido ou dos "espaços de representação", por sua vez, constituem-se nas experiências no espaço. Eles são vividos e falados, "têm um núcleo afetivo: o Ego, o leito, o dormitório, a casa; ou a praça, a igreja, o cemitério. Contêm os lugares de paixão e de ação, os lugares das situações vividas e, por conseguinte, implica imediatamente ao tempo" (LEFEBVRE, 2013, p. 100). O vivido é, certamente, o espaço determinado pelo corpo e por ele se configuram as apropriações. O vivido denota valor de uso e pode colocá-lo acima do valor de troca, alterando o tecido do espaço social e subvertendo o espaço abstrato em lugar da vida, do habitar.

Segundo Lefebvre (2013), o espaço abstrato tem um grande impacto no tecido social e na produção do espaço, pois são espaços construídos a partir de saberes como o da arquitetura. Não se pode, contudo, separar e manter separados os espaços abstratos dos vividos ou, melhor posicionando, as representações de espaço e os espaços de representação, bem como separálos das práticas espaciais. Pelo contrário, Lefebvre busca mostrar exatamente a indissociabilidade entre estes três espaços e suas dimensões.

Nenhuma das dimensões deve ser vista separadamente, portanto. Elas conflitam e se completam sem se esgotarem. O domínio de uma dimensão sobre as outras incorre no erro principal que Lefebvre busca denunciar em suas obras 
na temática urbana. Este domínio - que, a saber, é do espaço concebido exprime uma sociedade cuja relação de forças aponta para o domínio de determinadas classes sociais sobre as outras.

Seguindo nosso caminho conceitual podemos voltar, então, à guisa de finalização, ao trabalho e à luta de classes, agora aproximando ainda mais da produção do espaço urbano. Pela nossa perspectiva estes são temas centrais no entendimento da segregação socioespacial.

Esto equivale a concebir la naturaleza como algo modelado por la cultura, mientras toda la problemática social tiene su origen en la unión indisoluble entre estos dos términos a través del processo dialéctico mediante el cual una espécie biológica particular (particular puesto que está dividida em classes), el "hombre", se transforma y transforma su médio ambiente en su lucha por la vida y por la apropiación diferenciada del producto de su trabajo. (CASTELLS apud VILLAÇA, 2015, p. 31)

Castells, dessa maneira, insere à questão do trabalho a luta de classes em sua problemática: a apropriação diferenciada do produto do trabalho. A partir dessa compreensão, Villaça (2015, p. 32) nos mostra que: se o espaço urbano é um produto resultado do trabalho dos homens, "há uma luta de classes visando à apropriação do trabalho diferenciado", ou seja, a produção do espaço então necessariamente gera produto que, nos entendimentos marxistas supracitados, nos faz inferir que há uma disputa pela apropriação individual (ou de classe) sobre o trabalho social e coletivamente produzidos. Essa luta é, como afirma Lefebvre, latente no espaço urbano: "Pelo que diz respeito à luta de classes, seu papel na produção do espaço é fundamental, pois classes, frações e grupos de classes conformam os agentes da produção espacial. A luta de classes pode ser lida no espaço atualmente mais do que nunca" (LEFEBVRE, 2013, p. 113).

No curso do estabelecimento desse mesmo espaço abstrato tem lugar uma situação não menos importante (...): a substituição do habitat ao habitar; caracterizado este pela abstração funcional. As classes dominantes se apoderam do espaço abstrato à medida de sua constituição, como resultado de sua ação política, mas não se confunde com esta ação; o utilizam como um instrumento de poder sem omitir, todavia, os outros usos possíveis: a organização da produção e dos meios de produção, 
o lucro em definitivo (LEFEBVRE, 2013, p. 349-350, tradução nossa) ${ }^{22}$

Buscamos mostrar nesta parte de nossa pesquisa, portanto, que os espaços abstratos são produzidos de forma circunstancial, de acordo com os interesses e questões momentâneas e não de acordo com o conhecimento e aspirações da sociedade como um todo. Não são produzidos para o habitar, assim como afirmou Lefebvre sobre a construção de uma rodovia: "É um espaço realmente produzido, mas produzido como um bem de consumo corrente e não como um conjunto para o habitar e para a vida, etc., o que ainda deve ser inventado. É a testemunha do fato de que um espaço novo foi inventado, mas pouco satisfatório" (LEFEBVRE, 1972, sp).

\subsection{Segregação: abordagens formais}

Desde a Revolução Industrial, com a divisão social do trabalho e questão habitacional de massa como problema urgente (ENGELS, 2015), a segregação vem ganhando cada vez maior destaque entre estudos econômicos e sociológicos. Segundo Correa (1989), diferentes abordagens quanto à descrição de padrões de segregação nas cidades podem ser observadas ao longo dos séculos XIX e início do XX, com enfoque na Europa e Estados Unidos. Correa (1989) destaca os modelos apresentados por Kohl, em 1841, por Burgess, na década de 1920, e por Hoyt, ainda em 1939.

O primeiro foi desenvolvido buscando descrever um padrão de ocupação do espaço urbano pelas classes em círculos concêntricos. Esse padrão corresponde ao período no qual o sistema capitalista ainda não havia modificado a produção do espaço urbano, de forma que as elites procuravam se concentrar próximas dos serviços e instituições, todas localizadas nos centros das cidades. Dessa forma, o centro é ocupado pelas elites e as periferias ocupadas por populações de menor poder político e econômico.

Com as indústrias se aproximando cada vez mais das cidades, Burgess observa o gradual abandono do centro pelas elites, que se mudam para as periferias bem estruturadas das cidades. Os centros passam a ser ocupados

${ }^{22}$ Apresentaremos essa substituição do habitar pelo habitat no capítulo seguinte. 
pela classe operária, fazendo emergir o fenômeno dos cortiços. Burgess, então, descreve o padrão de distribuição das classes sociais em círculos concêntricos, mas inversamente ocupados em relação ao modelo de Kohl, com a classe operária no círculo central e as elites no círculo mais externo.

Os padrões de ocupação em círculos, contudo, tornaram-se obsoletos em relação à evolução dos meios de transporte e comunicação, que modificaram as formas de ocupação das cidades. A descrição realizada por Hoyt, então, passa a ser a que melhor sintetiza o padrão de segregação do início do século XX, no qual a ocupação do espaço urbano é determinada pelas elites que controlam o espaço e os deslocamentos, ocupando as porções de melhores características dos territórios das cidades do centro à periferia, formando um setor nessa direção. As classes médias ocupariam, nesse modelo, setores próximos aos ocupados pelas elites e, à classe de menor poder aquisitivo restaria ocupar as porções restantes. Hoyt, portanto, coloca o fator de domínio do espaço pelas elites urbanas, imputando a elas o controle dos espaços e, consequentemente, como causadoras da segregação socioespacial.

Correa (1989) adverte ainda que esses modelos podem coincidir em uma mesma cidade, conformando um modelo de ocupação mais complexo. Para as cidades da América Latina, por exemplo, o modelo de organização espacial de classes que melhor descreve a ocupação do espaço urbano foi desenvolvido por Yujnovsky em 1971 (CORREA, 1989), no qual observa-se a complexificação e sobreposição dos modelos anteriores.

Yujnovsky propõe que a ocupação dos espaços pelas classes sociais cria centralidades dentro delas e favelas em áreas fronteiriças distribuídas pela cidade. As classes dominantes se distribuem por um setor a partir do centro, semelhante ao modelo de Hoyt, mas Yujnovsky demonstra um prolongamento do centro ocasionado pela ocupação dessa parcela da população. Essa espécie de prolongamento pode ser observada nos estudos de Villaça (1985) sobre São Paulo (SP) nos quais se demonstra que há um controle físico e midiático do centro pelas elites urbanas de forma a direcioná-lo em direção às áreas de expansão do setor comercial e imobiliário voltado à essas elites. 
Esses são alguns dos modelos ${ }^{23}$ de segregação descritos e adotados por pesquisadores que norteiam a leitura dos espaços urbanos. Contudo, tendo em vista aprofundar no tema, procuraremos indicar algumas abordagens conceituais de segregação, revelando pontos de similaridade e diferenças de leitura.

\subsection{Segregação: abordagens conceituais}

Os sistemas práticos de diferenciação e, portanto, os sistemas de segregação, estão, via de regra, atrelados à distinção entre as pessoas em suas características visíveis e/ou, se possível, ao agrupamento de grupos sociais "marginalizados"24 em determinados territórios. Esses sistemas visam, resumidamente, o poder sobre as riquezas e o controle sobre a sua distribuição entre as pessoas. Os aparatos jurídicos, legislativos, culturais e econômicos são instrumentos balizadores desses sistemas, norteando e corroborando com as práticas cotidianas de exclusão/segregação ou, em determinados casos, escamoteando o sistema de exclusão/segregação através de uma falsa igualdade que não tem validade na dimensão sensível. Esse processo é historicamente constituído e combatido, com maior ou menor alteração dos padrões de segregação e das populações segregadas. Como afirma Lefebvre (2013, p. 362): "O direito e a justiça organizaram a injustiça, e a igualdade encobriu a desigualdade, cuja realidade não era menos flagrante, mas mais difícil de combater"

A segregação socioespacial tem sido amplamente debatida desde 0 fenômeno do crescimento e inchaço das grandes cidades. Não há um consenso sobre os processos causadores da segregação ou até mesmo sobre a sua definição e conceituação. Fato é que a segregação é sempre relacional: um espaço e sua população estão segregados em relação a outros espaços e

\footnotetext{
${ }^{23}$ Correa descreve parte desses padrões como "possibilidades teóricas" (1989, p. 73)

${ }^{24}$ Expressão muito utilizada para denominar pejorativamente pessoas em situação de pobreza, moradores de territórios de pobreza metropolitana e, principalmente, criminosos de pequenos delitos (assaltantes e ladrões). Nesse caso, contudo, utilizamos a expressão para denominar aqueles que estão à margem em diferentes esferas, como dos serviços estatais, da economia e emprego formais, da cultura, da sociabilidade, dentre outros.
} 
populações. Outro fator importante de ser entendido é que a segregação é, sobretudo, residencial. As áreas de ocupação das populações em suas residências são as analisadas nos estudos sobre segregação. Não se exclui, contudo, a análise das densidades urbanas e suas dinâmicas diárias, determinantes nos estudos sobre segregação, como os deslocamentos OD (Origem-Destino) do local de residência para o de trabalho.

A segregação é um fenômeno urbano que deve ser estudado dentro de suas características. Deve-se fazer, primeiramente, o esforço de diferenciação entre a segregação e outros conceitos e fatores similares - e até constitutivos à segregação. Dessa forma, conceitos como os de "exclusão" ou "exclusão social", "pobreza urbana" e "inserção social” são relacionados e, por vezes, confundem-se com o de segregação.

Mas, se estamos falando sobre parcelas da população que são apartadas de espaços, oportunidades e sociabilidades, porque falar em segregação e não em exclusão? E, se estamos falando de porções territoriais que concentram indicadores sociais negativos ou positivos, porque falar em segregação e não em pobreza urbana?

Podemos destacar resumidamente que embora as sobreposições e semelhanças entre os conceitos, a segregação tem como fundamental a dimensão espacial, de forma a incluí-la não apenas como produto, mas como reprodutora de uma estrutura social que promove a diferenciação social no espaço. "A segregação é, por definição, uma categoria espacial” (TORRES. In: SPOSITO et al, 2004, p. 101) A segregação, destarte, deve ser vista tanto em relação ao consumo do espaço quanto de sua produção (VILLAÇA. In: SPOSITO et al, 2004, p. 105).

Na realidade, a segregação deve abarca as dimensões espacial, temporal, social/cultural e econômica; tendo em vista que em uma sociedade capitalista, cujo mediador social é o dinheiro, a questão econômica torna-se central, alterando as demais. Assim, o acesso à cultura, às sociabilidades, aos espaços e os tempos são mediados e influenciados pelo fator econômico. No Brasil, ademais, não se pode desprezar o fator racial como intensificador da segregação 
e da imobilidade social, tendo em vista o seu peso nos indicadores sociais, como veremos adiante.

Segundo Torres (In: SPOSITO et al, 2004, p. 101), "a categoria segregação fala de um fenômeno e a exclusão se refere muito mais ao registro da desigualdade". Populações que foram segregadas em determinados espaços apresentam, de modo geral, o acúmulo de vulnerabilidades e índices negativos. Ocupações irregulares, favelas e bairros periféricos pobres têm como características comuns apresentarem os menores índices de escolaridade, renda, emprego, segurança e saúde, dentre outros. O conceito de pobreza deve ser tratado com cuidado, portanto, tendo em vista que pode limitar as análises sociais aos parâmetros econômicos de renda, escamoteando a perpetuação da pobreza, pois esta não pode ser desligada dos fatores territoriais e de escolaridade, por exemplo.

Outro fato que nos leva a uma análise mais cuidadosa quanto à pobreza urbana é destacado por Torres (2005, p. 87): “(...) embora uma série de autores brasileiros associe segregação residencial a ausência de serviços públicos (...), a segregação sócio-espacial pode existir e mesmo aumentar em situações de plena universalização dos serviços públicos e de crescimento da renda"

Quanto à "exclusão" ou a "exclusão social", pode ser definida, segundo o "Atlas da exclusão social no Brasil - Dinâmica e manifestação territorial" como:

(...) um fenômeno transdisciplinar que diz respeito tanto ao não acesso a bens e serviços básicos como à existência de segmentos sociais sobrantes de estratégias restritas de desenvolvimento socioeconômico, passando pela exclusão dos direitos humanos, da seguridade e segurança pública, da terra, do trabalho e da renda (CAMPOS, POCHMANN, AMORIM \& SILVA apud KAZUO, p. 131. In: Revista Espaço \& Debates n. 45, 2004).

Porém, como afirmou Kowarick: "A rigor, não há pessoas excluídas, mas incluídas marginalmente" (In: SPOSITO et al, 2004, p. 96). Ou seja, não se pode pensar nas populações de áreas segregadas como excluídas, pois, como ressalta o próprio Kowarick, elas estariam "fora ou dentro de quê?" Dessa forma, a abordagem dicotômica imposta pelo uso do termo "exclusão" poderia nos levar, sem os devidos cuidados, ao erro de analisarmos os espaços urbanos de forma 
estática e parcial, pois não abarcaríamos a totalidade do fenômeno e o seu movimento.

Outra crítica ao tipo de leitura dicotômica pode ser feita a partir dos estudos mais atuais no Brasil sobre pobreza urbana, realizadas a partir do início dos anos 2000, sobretudo. Estudos como os de Rizek (2006; 2017) e Abílio (2011) apontam para uma presença cada vez maior do Estado em territórios de pobreza, o que não exclui a reprodução da pobreza, mas, pelo contrário, indica um gerenciamento da força produtiva presente nestes territórios e também a gestão da própria pobreza. Dessa forma não se pode mais, atualmente, referirse à pobreza urbana como "exclusão" ou como "ausência do aparato estatal", análise comumente realizada até os anos 2000; o que nos direciona novamente à centralidade dos estudos sobre segregação como forma de entendê-la enquanto fato, enquanto processo e as consequências socioeconômicas para as pessoas em territórios segregados e para a sociedade.

O Estado, segundo apontam esses estudos, promove a gestão da pobreza ao submeter políticas públicas e direitos sociais ao consumo e à lógica do mercado, relegando as pessoas a um lugar de passividade e retirando os direitos do campo político. Ademais, promove "mobilidades laterais" (RIZEK, 2012, p. 71) que não significam a superação da pobreza ou a ampliação da autonomia. $A$ partir das políticas culturais analisadas por Rizek (2012) em territórios de pobreza, por exemplo, podemos apontar para o deslizamento semântico da cidadania que, então, passa a ter seu significado ligado aos "mecanismos do dinheiro" (RIZEK, 2012, p. 77) e a um protagonismo limitado e difuso.

Em "O espaço do cidadão", Milton Santos (2014) analisa quais os fatores que compõe a cidadania e o que seria necessário para a população conseguir, efetivamente, a cidadania no Brasil. Segundo Santos (2014), a partir da ascensão das ideias neoliberais no país, o espaço do cidadão tem sido gradualmente instituído por meio do consumo, ou seja, descaracterizando-se a cidadania enquanto categoria política. Para Santos (2014, p. 141, grifos meus): "A localização das pessoas no território é, na maioria das vezes, produto de uma combinação entre forças de mercado e decisões de governo. (...) Isso equivale 
também a falar de localizações forçadas. Muitas destas contribuem para aumentar a pobreza e não para a suprimir ou atenuar"

A crítica a uma leitura fatalista do espaço pode ser realizada também aos estudos de pesquisadores ligados a importantes correntes do pensamento sociológico urbano, como os da Escola de Chicago a partir da década de 1920. Os estudos realizados pelos pesquisadores ligados à essa escola foram pioneiros em determinados aspectos, influenciando a construção da sociologia urbana enquanto vertente científica. Esses estudos apontaram para a segregação como algo inerente à produção do espaço urbano, pois é também inerente aos humanos separarem-se e agregarem-se em grupos e disputarem pelas melhores localizações e facilidades para a realização da vida.

A Escola de Chicago teve como expoente o sociólogo Robert Park, que usou a expressão "ecologia humana" para ilustrar os modos de relação competitivo entre as pessoas, algo que foi transportado para as formas de ocupação dos espaços urbanos. Assim, as pessoas que melhor se adaptam à vida urbana são as que conseguem as melhores condições de vida, um tipo de darwinismo social. Com isso, a segregação vista de forma "natural" ao sistema de produção do espaço urbano dota de imobilidade e fatalidade o fato da apropriação desigual dos espaços das cidades.

É senso comum tratar a segregação como a descrição de um território ocupado por uma parcela da população que cuja liberdade de escolha do local de moradia é limitada por seu poder aquisitivo ou, ainda, que estão segregadas as pessoas de certa etnia ou de alguma característica cultural por se concentrarem em determinadas porções do espaço urbano, os chamados guetos.

Essa última abordagem comum tem respaldo maior na realidade de países europeus, nos EUA e África do Sul (dentre outras, obviamente), nações de constituição histórica das cidades caracterizada pela separação territorial clara entre populações de diferentes origens étnicas e culturais, como no sistema do apartheid sul-africano, ou como os judeus, os negros e os latino-americanos em diferentes países. 
Para a análise do espaço urbano, os estudos que indicam a segregação como inerente e natural à produção do espaço ou, ainda, aproximando a segregação de uma escolha individual faz com que se perca a dimensão ativa da luta de classes e, também, possibilidades prospectivas para o combate a esse problema. Do contrário, a segregação vista como fenômeno e explicada no seio do capitalismo brasileiro nos leva a pensar em uma intencionalidade, em um movimento motivado por sujeitos de ação, deixando de ser algo subjetivo, fatalista e quase imutável; e trazendo a segregação para o campo das possibilidades de alteração dessa realidade a partir do seu conhecimento.

Ainda sobre as diferentes compreensões sobre a segregação, Suzana Pasternak (In: SPOSITO et al., 2004, p. 102) lembra de OImsted ${ }^{25}$ para ressaltar que a segregação pode ser vista até como algo positivo em alguns países. Segundo a autora, Olmsted tinha a concepção de que "as pessoas só ficam bem quando vivem entre iguais" (PASTERNAK, In: SPOSITO et al., 2004, p. 102). A autora ressalta que Olmsted considerava os espaços públicos como potenciais para a convivência entre iguais e diferentes, como elementos importantes para dirimir a separação entre as pessoas. Esta concepção dos espaços públicos como mediadores de encontros entre os diferentes pode ser válida tendo em vista a quantidade, localização e qualidade dos espaços públicos em Nova lorque, cidade referência para Olmsted, o que difere da realidade brasileira.

No caso brasileiro, Villaça (In: SPOSITO et al., 2004, p. 105) afirma que a ideia de segregações inofensivas (...) que se agregam para manter costumes, vínculos culturais etc. é tentadora", mas é subjugada pela segregação por classes. Isso porque mesmo um território de alta concentração de determinado grupo étnico se dá dentro das possibilidades econômicas dos indivíduos desse grupo, indicando que a segregação não é independente de questões de classe.

Também com relação à segregação de grupos étnicos, temos o estudo de Mohammad Qadeer (2004) sobre a concentração de imigrantes em determinados territórios de Toronto, no Canadá. Qadeer (2004, p. 44) afirma que "A segregação espacial étnica surge quando há a convergência entre as

\footnotetext{
${ }^{25}$ Frederic Law Olmsted, paisagista que projetou o Central Park em Nova lorque, EUA.
} 
preferências residenciais do imigrante e oportunidades para áreas específicas", sendo as oportunidades definidas pelo mercado imobiliário, por instituições transnacionais e por políticas públicas (QADEER, 2004, p. 44).

Cabe ressaltar, todavia, que em Toronto a realidade habitacional apresenta certa qualidade, mesmo a dos imigrantes (QADEER, 2004, p. 42), diferentemente das metrópoles brasileiras. Portanto a vulnerabilidade social tem um peso menor na segregação. Assim, podemos considerar que mesmo os guetos norte-americanos ou europeus devem ser analisados considerando-se também o fator voluntário da concentração de determinados grupos étnicos, pois há mais possibilidades de escolha de territórios a serem ocupados do que em países de "capitalismo periférico" ou "em vias de desenvolvimento".

A ocupação do espaço urbano se dá de acordo com as possibilidades inerentes à renda e status que as pessoas têm de acordo com a sua classe social. Dessa forma, toda segregação tem um fator coercitivo pois, em sua origem, exprime a relação desigual de liberdade de escolha do local de moradia. Ademais, "Em qualquer circunstância (...) a produção da segregação e da desigualdade de acesso não é automática ou natural, e a dinâmica política importa" (MARQUES, 2005, p. 49).

Este é um dos pontos de inflexão entre a teoria de Villaça $(1985 ; 2015)$ e Marques (2005) pois, segundo Villaça, o processo de segregação engendrado pelas classes dominantes visa concentrar esforços no controle do espaço, o que passa necessariamente pelo exercício de influência no aparato estatal e midiático, promovendo e intervindo nos espaços de acordo com os interesses econômicos e de qualidade de vida dessas elites.

Um dos pesquisadores mais relevantes no que tange à segregação é Peter Marcuse. Segundo ele, a "Segregação (segregation) é o processo pelo qual um grupo populacional é forçado, involuntariamente, a se aglomerar em uma área definida, em um gueto. É o processo de formação e manutenção de um gueto" (MARCUSE, 2004, p. 24, grifo meu). O autor tem clara influência das realidades urbanas estadunidense e europeia na formulação de seu 
pensamento, tendo em vista os históricos de constituição de guetos de populações marginalizadas nessas sociedades, como acima mencionado.

Ainda segundo Marcuse (2004), a segregação pode ser entendida em três diferentes formas, que podem se sobrepor ou se contradizer: as distinções culturais, as de papeis funcionais e econômicos, e as de hierarquia do poder. De acordo com este autor, "enquanto as divisões por função e as divisões culturais são em geral voluntárias, as divisões por status não o são" (MARCUSE, 2004, p. 28). Assim, há também na teoria de Marcuse o fator coercitivo da segregação e com forte presença do Estado nessa coerção, que é foco do trabalho do pesquisador. O Estado exerce sua capacidade de "impor divisões" tanto através da força física quanto atendendo aos "desejos dos detentores de poder político e econômico" (MARCUSE, 2004, p. 28) ou, ainda, omitindo-se de combater a segregação. "Assim, se em qualquer sociedade houver segregação ela ocorrerá com a sanção tácita, quando não explícita, por parte do Estado" (MARCUSE, 2004, p. 30)

Nota-se que Marcuse (2004) vê a segregação a partir do ponto de vista de quem foi segregado, ou seja, quem sofreu algum processo de alocação forçada em determinado espaço. Por outro lado, para Villaça (In: SPOSITO et al., 2004, p. 94) a segregação deve ser vista a partir das classes de maior poder político e econômico, definindo a segregação como a "grande concentração de camadas de alta renda" em áreas das cidades, sobretudo em metrópoles. Villaça parte do princípio de que aqueles que têm maior influência na produção do espaço, as elites urbanas, constituem os grupos que constroem a segregação a partir de seus próprios espaços.

Villaça (2015) mostra que as elites urbanas paulistanas têm como objetivo gozarem das benesses urbanas (acessos a equipamentos e serviços, proximidade com os locais de trabalho e lazer, deslocamentos facilitados e até mesmo fatores climáticos e ambientais) e, para isso, se apropriam do fruto do trabalho coletivo, a localização, por meio do controle do espaço.

Segundo Villaça (1985; 2015), então, a concentração das elites em espaços determinados é um fator essencial para que haja a confluência dos 
investimentos e melhorias urbanas estatais nessas localidades, produzindo espaços com as qualidades urbanas desejadas. A concentração dessas elites em determinados espaços acaba por engendrar o processo de expulsão de classes de menor poder aquisitivo e político para espaços que apresentam menos qualidades. Como já mencionado acima, o produto da produção do espaço é a localização, vista como monopólio (VILLAÇA, 1985).

Villaça (In: SPOSITO et al., 2004) adverte que seu estudo se estrutura a partir de grandes regiões como categorias de análise. Explica também que essa metodologia se aplica melhor a regiões metropolitanas ou metrópoles. Explicar pelas classes sociais a segregação tem maior poder de articulação com a totalidade social, o que representa uma grande vantagem de pesquisa, segundo ele.

Torres (2005, p. 83) tem entendimento semelhante, apontando que os fatores que levariam à essa aglomeração de grupos sociais passam desde os mecanismos do mercado, "que induzem a valorização ou desvalorização imobiliária de determinadas áreas", como pelos instrumentos institucionais, como "taxação, investimentos públicos, remoção de favelas, etc.", e pelas práticas efetivas de discriminação, como as realizadas por parte de agentes imobiliários; estes incentivados pelo fenômeno da cultura da diferenciação social, como afirma Kowarik:

Em relação à segregação, considero que atualmente há um elemento essencial que é o processo das pessoas evitarem outras que são vistas como diferentes delas, tidos e havidos como potencialmente perigosos, onde novamente penetra a questão do preconceito racial; é a questão da cidade de muros, como a Teresa Caldeira mostrou (In: SPOSITO et al.,Revista Espaço \& Debates, 2004, p. 96-97).

Kowarick cita Teresa Caldeira (2000), autora do livro "Cidade de Muros" que desenvolveu um importante estudo que avança em uma compreensão mais ampla sobre segregação em São Paulo, SP, ao relacionar diferentes dimensões e tempos históricos para explicar o crescente fenômeno dos condomínios fechados nas décadas de 1980 e 1990. Segundo a autora, o padrão de ocupação pelas classes estruturava-se sobre o binômio centro-periferia, com grande parte 
da força de trabalho ocupando as periferias da cidade. A imobilidade social era controlada pela força coercitiva do Estado ditatorial entre 1964 e 1985.

Com o processo de redemocratização do Estado, concomitante a uma crise financeira e institucional, há a mobilização das populações de periferia e, por conta das crises, há também o aumento dos índices de desemprego e criminalidade. Essa combinação, somada ainda à precarização da infraestrutura urbana, leva ao crescimento da percepção e da narrativa da violência nas mídias e entre as elites urbanas.

Aderindo a essa narrativa e impulsionados pelo mercado imobiliário parte das elites urbanas passa a produzir e ocupar áreas em não centrais e bem estruturadas da cidade, fazendo emergir um novo padrão, mesclado com o anterior, que resulta em um "desejo" de segregação formando "enclaves fortificados" auto-segregados que conferem status aos moradores (CALDEIRA, 2000 , p. 259). Estes são os condomínios fechados ${ }^{26}$, encerrados entre altos muros. Esse tipo de isolamento é, segundo Lefebvre (2013, p. 355), demonstrado apenas em "casos extremos de separação".

O marketing de vendas de residências nesses condomínios é apelativo quanto à segurança e à possibilidade de um cotidiano "sem inconveniências" que, como mostra Caldeira (2000, p. 268), refere-se subjetivamente ao isolamento das classes altas do contato espontâneo com pessoas de outras classes sociais ${ }^{27}$. Há, concomitante a isso, a redução e precarização dos espaços públicos na cidade e a dispersão das elites urbanas em espaços no formato de condomínios em localidades com amenidades.

Caldeira, então, relaciona a segregação com a dimensão cotidiana da metrópole paulistana, algo que nos faz aproximar dos efeitos da segregação para

\footnotetext{
${ }^{26}$ Temos como exemplo mais icônico o condomínio Alphaville, em São Paulo-SP, que conta com um muro de 64 quilômetros de extensão dentro da malha urbana paulistana. Este muro foi um dos destaques da revista The Guardian em matéria sobre sociedades divididas por muros.

Visto em: <https://www.theguardian.com/world/ng-interactive/2013/nov/walls\#intro> Acesso em: 12 dez 2017.

${ }^{27}$ Cabe ressaltar que Caldeira $(2000$, p. 275$)$ também trata do cotidiano interno dos condomínios fechados, revelando as dificuldades de convivência: "O problema central dos condomínios e edifícios parece ser como funcionar como uma sociedade com algum tipo de vida pública". Ao ideário de harmonia pela convivência entre iguais parece faltar, sobretudo, o que o cotidiano entre diferentes propicia: o respeito às diferenças.
} 
além da descrição do processo acabado. Seu estudo amplia a compreensão sobre a segregação enquanto fenômeno ligado à totalidade do urbano e permite observá-lo contextualmente e dialeticamente.

Voltando à Villaça (1985; 2015), é importante notar que o autor coloca a segregação como parte da luta de classes, denunciando uma parcela da população como determinante na produção de espaços desiguais. $O$ autor, dessa forma, tira os principais agentes produtores do espaço urbano de trás da projeção de culpa de "um sistema", de algo genérico e indeterminado. Com base teórica marxiana, Villaça $(1985 ; 2015)$ dota de materialidade a segregação. A concentração de uma classe em um determinado território é, portanto, uma ferramenta de domínio do espaço (VILLAÇA, In: SPOSITO et al., 2004, p. 106) e tem como uma de suas consequências (e objetivo) o controle das populações nos espaços.

Marques (2005) tem uma leitura semelhante à de Villaça no sentido da concentração de grupos sociais e, assim como autores supracitados, aponta para o papel do Estado na promoção e manutenção das desigualdades sociais e da segregação, consequentemente (veremos mais sobre o papel do Estado adiante). Marques (2005) coloca a segregação como uma "separação" entre os grupos e se aprofunda no caráter relacional, complementando que a "segregação significa desigualdade de acesso, em várias acepções da expressão" (2005, p. 33). Relaciona-se, assim, com a pobreza urbana e coloca o foco de seus estudos nas áreas que concentram índices de precariedade. Como afirma Torres (In: SPOSITO et al., 2004, p. 101), "A segregação não é uma mera curiosidade sociológica, mas tem impacto significativo do ponto de vista das probabilidades de avanço social"

Buscando um entendimento sobre a segregação, Marques (2005) realiza o exercício de retomar algumas compreensões sobre essa categoria sociológica. O autor assinala que podemos observar três abordagens gerais: i) levada ao extremo, com a separação (e isolamento) de grupos sociais em guetos, algo que não pode ser utilizado no caso brasileiro tendo em vista que não há "dispositivos legais em nossas cidades" (2005, p. 31) de controle territorial de grupos sociais; ii) como "as desigualdades de acesso às políticas públicas ou de condições de 
vida de uma forma geral" (2005, p. 33), a interpretação mais difundida até o início dos anos 2000, sobretudo, e; iii) como "homogeneidade interna e heterogeneidade externa na distribuição dos grupos no espaço" (2005, p. 34).

Marques (2005, p. 34) explica a construção do "índice de dissimilaridade" e o relaciona ao "processo de segregação, entendido como separação, com formas de acesso desigual a oportunidades e serviços". Este índice está ligado à última das três abordagens relatadas acima e seria, segundo Marques (2005, p. 85): "a proporção da população (de um dado grupo social) que teria de se mudar para que a distribuição de cada grupo social em cada área fosse similar à distribuição existente para o conjunto da cidade"

É importante notar que Marques (2005) avança para além da dimensão espacial e chega ao "espaço vivido", ao cotidiano e às sociabilidades das populações de áreas de pobreza. Uma das estratégias indicadas pelo autor para o combate à separação das pessoas em grupos seria a "produção forçada de percursos" (MARQUES, 2005, p. 51), que deve ser relativizada de acordo com qual população é forçada e se deslocar. Afinal, um equipamento localizado em um bairro rico que exige o deslocamento de populações pobres só reafirma 0 caráter de desigualdades de acessos.

Marques inclui trajetos e percursos (2005, p. 53) como fatores de maior mistura, o que podemos relacionar com o defendido por Netto (2013) sobre as apropriações dos espaços que, segundo o autor, pode ser ampliada ou limitada de acordo com as opções e facilidades de mobilidade dos sujeitos no espaço urbano. Essa visão vai ao encontro da questão das sociabilidades e das apropriações dos espaços como fatores relacionados à segregação socioespacial, entendimento que temos no presente trabalho.

A Marques (2005) interessa saber também, portanto, quais as consequências na vida cotidiana para as populações mais pobres de se morar em espaços marcados pela alta concentração de precariedades e pela ausência ou debilidade de equipamentos, bens, serviços e empregos, dentre outros (o que se nomearia, décadas atrás, como ausência do Estado). Marques (2005) 
estudou redes de sociabilidades e sua importância na manutenção e/ou no incremento da qualidade de vida. Para o autor:

(...) as informações empíricas existentes mostram que, na cidade, as diferenças de oportunidade não são apenas socialmente especificadas, mas também espacialmente delimitadas, e as oportunidades ao alcance dos pobres das periferias são muito menores que as disponíveis para os pobres das áreas habitadas pelos grupos de maior renda" (MARQUES, 2005, p. 53, grifos meus).

A desigualdade de oportunidades de acordo com a localização é também item de reflexão de Milton Santos (2014, p. 151). O autor nos mostra que "O cidadão é um indivíduo num lugar". Desta forma não se pode separar as condicionantes culturais, econômicas e sociais das territoriais para a cidadania. Ainda segundo o geógrafo:

Indivíduos que disponham de uma soma de capital, formação cultural e capacidade física equivalente, ocupados num mesmo tipo de atividade - para não falar senão dessas qualidades comuns - são, sem embargo, dotados de possibilidades efetivas sensivelmente desiguais, conforme os diferentes pontos do espaço em que se localizem (SANTOS, 2014, p. 108).

$\mathrm{Na}$ mesma obra dos estudos de Marques está o de Almeida e D'Andrea (2005), que nos mostra que periferias com maior coesão cultural, mais consolidadas, com maior vitalidade urbana e próximas às áreas ricas, tendem a oferecer maiores oportunidades de emprego e redes mais amplas e complexas de sociabilidades, como é o caso de favelas e bairros populares em São Paulo. Semelhante à este entendimento está o de Torres (In: SPOSITO et al., 2004, p. 90-91):

\begin{abstract}
A probabilidade de se conseguir trabalho é extremamente afetada pelo local de residência, na medida em que o principal fator para se conseguir trabalho em São Paulo é a rede de relações sociais da pessoa. (...) Nesse sentido, do ponto de vista de seu contato com uma rede de relações sociais com mais acesso ao mercado de trabalho, um pobre no centro da cidade é muito diferente de um pobre da periferia.
\end{abstract}

Do que o Torres coloca, podemos extrair que não é apenas uma questão de renda, mas o fator territorial influencia consideravelmente nas possibilidades de melhorias na qualidade de vida. Cabe ressaltar, contudo, que a ilegalidade de ocupação de uma área condiciona negativamente para o poder público levar a 
maior parte dos serviços públicos (TORRES, In: SPOSITO et al., 2004, p.91), o que nos leva a pensar sobre a importância da legalização e urbanização (com urbanidade ${ }^{28}$ ) das áreas ocupadas ou ainda da alocação de famílias para áreas onde terão posse ou segurança de posse da terra, ou seja, sendo proprietárias ou utilizando terrenos públicos.

Seguindo no sentido dos indicadores sociais, Pasternack (In: SPOSITO et al., 2004, p. 104) menciona que, no Rio de Janeiro, pessoas de mesma escolaridade e local de moradia tem rendas diferenciadas de acordo com a cor de sua pele. Algo muito semelhante é descrito por Torres, Ferreira e Gomes (In: MARQUES; TORRES, 2005) sobre as possibilidades de superação de vulnerabilidades a partir dos níveis de escolaridade de pessoas em territórios de pobreza. Segundo esses autores, pessoas economicamente pobres em diferentes territórios de pobreza (mais próximos ou distantes do centro; mais consolidados ou não) têm oportunidades desiguais de término do ciclo básico de educação; e os índices são ainda mais desiguais quando se leva em consideração o indicador da cor da pele.

Torres (et. al., 2005) busca estudar os fatores diferenciais entre estes espaços que poderiam apontar para a reprodução das desigualdades e, para tanto, apresenta uma série de dados que reforçam a ideia de que o fator espacial altera as possibilidades de ascensão social e de superação da pobreza, pois:

(...) enquanto um jovem de uma área de periferia com renda domiciliar de até 3 salários mínimos tem 0,261 (ou 26,1\%) de probabilidade de completar o ensino médio, um morador de uma área de elite, com o mesmo nível de renda, tem 0,331 (ou $33,1 \%$ ) de probabilidade de obter essa conclusão com 18 ou 19 anos (TORRES, 2005, p. 133, grifos meus).

Ao adicionar a dimensão étnica, Torres (et. al., 2005, p. 135) mostra que, dos jovens de mesmo nível de renda e moradores de diferentes regiões com concentração de precariedades, os que são brancos e moram em localização melhor (mais consolidadas, mais próximas do centro) têm quase o dobro de chances de se formarem no ensino médio: $36,2 \%$ contra $20,3 \%$ para os jovens

${ }^{28}$ Como nos mostra Correa (1989) e Benevolo (2011), mesmo ações de urbanização podem esconder o objetivo de controle estatal sobre o território, sendo este interesse prioritário em detrimento de reais melhorias na qualidade de vida dos moradores. 
negros e moradores de periferias pobres. Isso significa que à dimensão espacial, adiciona-se ainda componentes sociais e culturais que nos apontam para uma ampliação dos entendimentos acerca da segregação que possa abarcar também o cotidiano e seus contextos.

Com enfoque mais próximo ao cotidiano urbano, Netto (2014) aponta para as possibilidades de apropriações dos espaços de acordo com a classe social à qual os sujeitos pertencem. Netto (2014, p. 67) parte da compreensão de que a segregação "é uma forma de restrição da interação dos socialmente diferentes" e que isso ocasiona a "invisibilização do Outro, a geração de um sentimento de alteridades como estranhas entre si, a distância social, a instalação do medo do Outro e a necessidade do controle dos espaços" (2014, p. 85).

A abordagem de Netto se aproxima, então, do que Rancière (1996) coloca como controle dos corpos. Ou seja, a fragmentação à qual caracteriza uma cidade com espaços segregados estabelece a qual lugar cada sujeito e seu grupo social pertencem, apartando-os de outros sujeitos e grupos sociais. Colabora, então, para a diferenciação social e a tendência geral à redução da vida à esfera privada e, também, à concentração de grupos sociais em espaços de forma cada vez mais homogênea, alimentando um ciclo vicioso de segregação e diferenciação espaciais e sociais.

Marques (2005) explica que existem basicamente duas formas de o Estado atuar no intuito de dirimir diferenças socioespaciais. A primeira seria forçar a convivência entre diferentes grupos sociais, misturando mais ricos com mais pobres e tendo como resultado uma justiça espacial maior. Outra opção é prover os territórios mais pobres com equipamentos e infraestrutura de qualidade, equiparando (ou tentando, pelo menos) os acessos dos grupos mais pobres com os mais ricos, permitindo uma equidade espacial nesse sentido.

O Estado, segundo Marques (2005), poderia atuar a partir de duas estratégias que contemplam as duas formas de combate às desigualdades socioespaciais supracitadas: i) com políticas estatais sobre o ambiente construído, promovendo a organização e planejamento territorial urbano, provisão de infraestrutura, habitação, transporte e etc. e; ii) com políticas sociais 
organizadas espacialmente, promovendo saúde, educação, assistência social, políticas de transferência direta de renda, etc. Com o cruzamento dessas abordagens e estratégias teríamos cidades com menos desigualdades, segundo o autor.

Dos estudos e análises até aqui apresentados, podemos notar que tanto a produção do espaço abstrato quanto a promoção ou combate à segregação são práticas quase exclusivas do Estado. Este agente da produção do espaço poderia, em tese, servir como balizador dessa produção visando um maior equilíbrio entre as classes sociais e suas forças produtoras do espaço urbano e social. Contudo, o Estado é também um espaço em disputa, pois está suscetível em maior ou menor grau às vontades e forças de grupos sociais. Com isso pretendemos pontuar que o Estado não necessariamente produz segregação.

Cabe pontuar também que, contudo, no caso do PMCMV, como veremos adiante neste capítulo e no último, com base no processo de geração e implantação do programa, bem como nos resultados obtidos com essa política o Estado revela, com grande volume de dados, como o programa foi gestado e implantado de forma a obedecer ao mesmo padrão de política fundiária que está no centro da produção da restrição de acesso à terra urbanizada e, consequentemente, da crise habitacional. Assim, não há excesso ao apontarmos para a segregação como um objetivo da política habitacional do MCMV 29 .

Há de se considerar, no entanto, que, como nos mostra Lefebvre (1999; 2001 ; 2013), mesmo quando as ações estatais pretendem atenuar ou combater um problema urbano, essas ações são realizadas a partir de saberes pretensamente técnicos que não compreendem o espaço social em sua totalidade. Dessa forma, mesmo a intenção dos agentes estatais está subordinada às lógicas e práticas fragmentárias e ideologizadas. O espaço resultante dessas intervenções estatais deve ser entendido, segundo Lefebvre (1972), a partir de uma "análise espectral" em um duplo sentido da palavra: uma análise que observa que os elementos da vida urbana estão repartidos,

${ }^{29}$ As exceções de implantação do MCMV cuja arquitetura, inserção urbana e participação popular são razoavelmente positivas são tão raras que não podem ser mencionadas como casos de sucesso da política, mas sim de certo sucesso das equipes e instituições envolvidas. 
separados em blocos homogêneos como em um espectro de cores, quando as vemos perfeitamente separadas; ademais, espectral no sentido subjetivo, pois as vemos apenas como "um fantasma da existência", uma sombra do que deveria ser.

Entretanto, a segregação como um fato implica em questionarmos de qual modo ela foi "aceita" pela sociedade se, claramente, há a apropriação diferenciada do produto do trabalho social por indivíduos ou grupos específicos. Em outras palavras, poucos usufruem verdadeiramente do espaço construído por todos. Cabe lembrar, então, das compreensões de parte dos autores supracitados que apontam para a característica coercitiva da segregação. Essa coerção é descrita por alguns autores como violência estatal e, dentre eles, Lefebvre. O autor explica que o Estado tem suas ações orientadas por influência de seu corpo técnico e político - que por sua vez, fazem parte ou sofrem grande influência das elites econômicas. Dentro da perspectiva da luta de classes colocada por Lefebvre (entre outros, como vimos), as ações estatais de produção do espaço podem envolver diferentes formas de coerção/violência:

O espaço permite integrar o econômico ao político. (...) No espaço do poder, o poder não aparece como tal, se não como dissimulado sob a denominada 'organização do espaço'. Suprime, elude e evacua tudo que se opõe e ele mediante a violência inerente e, se esta não for suficiente, mediante a violência expressa (LEFEBVRE, 2013, p. 356, tradução nossa).

Ainda segundo Lefebvre (2013, p. 353, tradução e grifos nossos): "O espaço abstrato é, pois, em essência e por excelência, um espaço repressivo, mas o é de um modo particularmente hábil quanto múltiplo: a repressão imanente se manifesta tanto pela redução, pela localização (funcional), pela hierarquização e segregação como pela arte. (...) Esses objetos de arte, em geral abstratos, não figurativos em consequência, desempenham o papel de figurantes: representam admiravelmente o espaço 'circundante' que mata o entorno"

Com essa afirmação, o filósofo francês abre caminho para explorarmos também o papel dos monumentos, dos símbolos e das artes na produção de um espaço social de caráter fragmentário. Apontaremos brevemente, a seguir, para 
o uso da cultura, da arte e dos artistas em processos atuais de produção do espaço segregado, com estratégias renovadas de expulsão de populações e de valorização imobiliária de localizações até então "inertes" ao processo de acumulação de capital.

Nas últimas décadas, após o sucesso do "modelo Barcelona", intervenções urbanas são realizadas em grandes cidades com o intuito geral de promover determinadas áreas urbanas sucateadas ou subutilizadas. Essas intervenções podem receber diversos nomes, como reforma, revitalização, requalificação, reurbanização, renovação e etc., dependendo do foco da ação no espaço. Fazem parte de um "urbanismo estratégico" cuja narrativa tem sido amplamente aceita e colocada em prática em todo o mundo.

Os projetos visam atrair investimentos privados e justificar investimentos (gastos) públicos com obras que supostamente propiciarão um ambiente urbano favorável ao desenvolvimento da cidade nos aspectos culturais e econômicos. Dessa forma, tais obras são realizadas sobretudo a partir de parcerias públicoprivadas, as PPP. Com esse tipo de parceria o Estado, principalmente através do governo local, se exime de parte dos investimentos necessários para recuperação da área e, em contrapartida, cede espaço (físico e institucional) para que investidores privados consigam obter lucro.

Esses processos de "recuperação" de áreas urbanas degradadas, contudo, acaba por serem grandes responsáveis no fenômeno da gentrificação (gentrification, no termo original).O termo designa o processo de elitização ${ }^{30}$ de determinada área urbana a partir da valorização imobiliária causada por intervenções ou ações estratégicas de promoção dessa área, sendo uma das estratégias mais comuns o proposital sucateamento/abandono da área por promotores imobiliários com uma posterior retomada da ocupação da área a

${ }^{30}$ Gentry, utilizado na língua inglesa para nomear uma pequena aristocracia ou alta classe no passado. Visto em: <https://dictionary.cambridge.org/pt/dicionario/ingles/gentry> Acesso em: 22 dez. 2017 
partir da promoção dos trabalhadores e de iniciativas do setor cultural. Neste último caso, o exemplo mais icônico é o do Soho, em Nova lorque ${ }^{31}$.

A gentrificação, portanto, gera uma valorização estrategicamente pensada por promotores imobiliários, expulsando a população originalmente moradora da área que passa a ser local de moradia das classes média-alta e alta das cidades, empurrando os antigos moradores para bairros pior localizados e/ou menos estruturados. Este processo colabora com a concentração de classes em determinadas áreas e seu afastamento em relação às outras classes sociais, constituindo-se, assim, como mais um dos instrumentos geradores de segregação socioespacial.

Todos esses processos, formas e fenômenos mencionados e explicados no presente texto contribuem, no limite, para a reiterada alienação do espaço e da sociedade.

(...) as cidades como territórios de exceção, pelos quais passam os processos de concentração de renda, os novos modos de separação socioterritorial que isolam e expulsam 'a sociabilidade indesejável das classes 'perigosas', o controle policial, as altas taxas de homicídios, ou seja, as cidades são o território onde ganha materialidade e visibilidade $o$ retrato sem retoques de uma sociedade derrotada (RIZEK, 2006, p.221)

Resumidamente, o presente texto buscou mostrar, além das compreensões mais utilizadas nos estudos do tema, as consequências sociais da segregação: restrição das redes de sociabilidade; redução das chances de emprego e renda; externalidades mostradas, sobretudo, por Torres (2005) e Marques (2005), com a redução das chances de escolarização, emprego, redes sociais, etc); redução da mobilidade, com consequente redução das possibilidades de lazer, cultura, sociabilidades e apropriações, segundo Netto (2014). O controle dos corpos nos espaços é também um "efeito do espaço sobre o social” (VILLAÇA apud NEGRI). "(...) evidentemente esse espaço produzido é,

\footnotetext{
${ }^{31}$ Bairro que passou por um gradual processo de abandono seguido de uma massiva ocupação por artistas e intelectuais, tornando a área novamente atrativa à investimentos imobiliários e, consequentemente, expulsando os artistas e população remanescente para a ocupação de uma classe média alta nova-iorquina.
} 
ele próprio, social. Só o social pode constranger ou condicionar o social" (VILLAÇA apud NEGRI, 2010).

Portanto, a segregação em um sistema de interdependência social como uma cidade visa determinar os lugares de cada um nesse sistema. A ausência de apropriações pode revelar desigualdades de possibilidades e de espaços para a apropriação, o que revela muito, por conseguinte, sobre a desigualdade espacial e a segregação como produto das dinâmicas dos capitais urbanos e da ação do Estado.

\subsection{Papel da HIS na produção do espaço segregado no Brasil}

Para o entendimento da diferenciação social expressa no espaço urbano é necessária a compreensão da questão habitacional no sistema capitalista. Mesmo antes da divisão social do trabalho no sistema capitalista, as cidades já eram diferencialmente apropriadas. Como afirma Rolnik "A origem da cidade se confunde (...) com a origem do binômio diferenciação social/centralização do poder" (2004. p. 17). Porém, sob a lógica do capitalismo as diferenciações espaciais se tornaram cada vez mais claras na medida em que a produção do espaço passa a ter protagonismo nas relações entre classes.

A diferenciação e segregação espaciais inerentes à lógica capitalista de controle de monopólios, passa pela segregação residencial. A habitação pensada como um direito universal é, também, uma necessidade com alto valor de uso. Porém, o trabalho coletivo individualmente apropriado da produção de um produto com valor de uso transforma-o em mercadoria através de seu valor de troca. Assim, a habitação pode ser vista tanto pela apropriação que os moradores fazem dela em seu valor de uso, quanto em sua sujeição à lógica de mercado, tornando-a passível de compra, venda e especulação.

Não somente o valor de uso, mas, pelo alto custos de construção e pela, exige também uma política de financiamento e/ou de promoção imobiliária visando o seu acesso. Dessa forma, o Estado, que é o principal mecanismo de mediação entre mercado e sociedade, acaba por ter uma atuação fundamental na regulação do mercado e na provisão habitacional, levando-se em conta os 
custos e o tempo de produção de cada unidade habitacional. Ao observarmos o quadro da produção habitacional, concluímos que os altos custos necessários na produção habitacional - bem como a retenção de capital por um longo período para o construtor - fazem com que essa "mercadoria" seja de difícil acesso para as camadas economicamente mais pobres. Passa a ser do Estado o papel de buscar promover a habitação para essas camadas da população.

Outra questão que atrela o Estado à produção habitacional é o seu papel prático de organizador da produção capitalista e da massa de trabalhadores. Esse papel estatal é objeto de debates que datam ainda do século XIX, quando o movimento de aproximação das indústrias do espaço urbano mudou sua estrutura e lógica de produção e organização dos espaços, como nos apontou Lefebvre (2013) e também Engels (2015).

Contudo, a atuação do poder público em diferentes esferas nem sempre condiz com as necessidades apresentadas pela população, aproximando-se mais dos agentes privados do setor imobiliário e da construção civil, que têm no valor de troca das habitações seu único interesse.

Em primeiro lugar, a ação destes agentes se faz dentro de um marco jurídico que regula a atuação deles. Este marco não é neutro, refletindo o interesse dominante de um dos agentes, e constituindo-se, em muitos casos, em uma retórica ambígua, que permite que haja transgressões de acordo com os interesses do agente dominante. (CORREA, 1989. p. 12)

Dessa forma, a habitação têm sido um dos principais problemas a serem enfrentados pelo Estado brasileiro desde o início do século XX. O problema das condições insalubres e/ou irregulares das habitações, as coabitações, ocupações, favelas e cortiços são temas recorrentes e ainda longe de serem esgotados e, ainda mais distantes de serem solucionados. Porém, como é sabido, diferentes governos em diferentes períodos da história do Brasil se propuseram a intervir a fim de diminuir tal problema, atacando os déficits habitacionais com programas muitas vezes grandiosos.

A questão da habitação, no entanto, não é um problema pontual e sim estrutural, proveniente da adoção do modelo de economia capitalista e agravado pelo tipo de capitalismo aqui desenvolvido. Como já havia afirmado Bolaffi: 
[...] estes, como tantos outros problemas no país, têm sido formulados falsamente; formulados não a partir das características intrínsecas ao problema, mas a partir das necessidades da estratégia do poder e das ideologias que foram elaboradas durante os últimos quinze ou vinte anos. (BOLAFFI, 1982, p. 40)

A mudança do meio agrário para o urbano tem efeitos objetivos e subjetivos na nova população urbana que têm, como resultado, uma mudança no padrão de consumo.

Aos poucos, atividades tradicionalmente associadas ao trabalho doméstico são trazidas para dentro da economia de mercado capitalista - panificação, fermentação, cocção, preparação de alimentos, lavagem, limpeza e até mesmo a criação e socialização das crianças. Com respeito ao ambiente construído, a construção e conservação da casa integram-se à economia de mercado. (HARVEY apud MARICATO, 1987, p. 20)

Não apenas de consumo direto de mercadorias, mas também no consumo de serviços. Dessa mudança um elemento crucial nos interessa aqui: a habitação. A aquisição da casa própria passa a ser o sonho de consumo das classes média e baixa urbanas, não só pelo desejo, mas também pelas próprias dinâmicas econômicas que encareceram o aluguel. Segundo estudo realizado em 1960 por Loyd A. Free, citado por Bolaffi: “[...] a casa própria era a principal aspiração das populações urbanas brasileiras" (BOLAFFI, 1982, p. 43, grifos meus). Algo que persistiu durante um longo período e ainda se constitui como uma das principais aspirações populares. Isso se deu, ou melhor, foi reforçado, ainda segundo Bolaffi, por motivos objetivos e subjetivos para essas populações:

Subjetivamente, a aquisição de um imóvel se constitui na principal evidência de sucesso e da conquista de uma posição social mais elevada. Objetivamente, a casa própria não só melhora as possibilidades de acesso ao crediário, como libera o orçamento familiar da obrigação mensal inexorável do aluguel. (BOLAFFI, 1982, p. 43-44)

A política habitacional baseada na casa própria foi, então, retroalimentada: motivo de aumento da percepção da casa própria como elemento de desejo e, ao mesmo tempo, motivada por esse desejo crescente. O resultado pode ser lido nos números brasileiros apresentados por Maricato: "Em 1940, $64 \%$ dos domicílios urbanos eram alugados. Em 1991, essa proporção é de apenas 16\%" (MARICATO, 1987, p. 49). 
Mesmo a habitação sendo um elemento de tamanha importância para dinâmicas políticas, sociais e econômicas, a produção dessa mercadoria abrange ainda outros aspectos específicos que acabem exigindo a atuação do Estado na sua promoção para as camadas de renda mais baixa. Além de ser uma necessidade básica, Santos (1999) aponta ainda outros dois fatores que justificam tal atuação: a) tem custo elevado de produção, com baixa produtividade (BALL apud MARICATO, 1987; SANTOS, 1999; MARICATO, 2011b) e; b) a construção civil é um dos setores de maior geração de empregos, sobretudo os voltados à mão-de-obra desqualificada. A indústria da construção civil é uma das de maior impacto na econômico (FLORES apud MEDEIROS, 2010, p. 3), pois envolve diversos setores da produção e serviços urbanos, desde o mercado extrativista ao mercado imobiliário. A construção civil chegou a ocupar 7,2\% da população economicamente ativa em 1980 (MARICATO, 1987, p. 15) e é responsável pelo crescimento em cadeia de setores fabris e de serviços (MARICATO, 2011b).

Desta forma, devido às suas características específicas a habitação popular é objeto de ação de diferentes governos. A partir do acima descrito, têmse o panorama estabelecido para a criação da Política Nacional de Habitação (PNH) da Ditadura Militar brasileira, através da criação do banco que chegou a ser o segundo mais forte do país (BOLAFFI, 1982; VILLAÇA, 1986; MARICATO, 1987), o Banco Nacional de Habitação (BNH).

Não está no escopo do presente trabalho se estender no entendimento da política habitacional do último Período Militar. Contudo, vale apontar para seu caráter desenvolvimentista (ver MANTEGA, 1986; SANTOS, 2008; MARICATO, 2011b; ROLNIK, 2015) e populista, bem como para suas consequências na produção do espaço segregado. Segundo Rolnik (2015, p. 313-314):

A política habitacional desempenhou historicamente um papel central na consolidação do modelo urbano dessas regiões metropolitanas, assim como na reprodução de seu padrão de segregação socioespacial. A construção de grandes conjuntos habitacionais em áreas periféricas onde a terra é mais barata forma de provisão habitacional predominante ao longo de décadas - contribuiu substancialmente para impulsionar 0 espraiamento urbano, a proliferação de um padrão urbanístico monofuncional e o estabelecimento de uma divisão territorial entre ricos e pobres. 
O país chega em 1964 apresentando um quadro de intensa desvalorização da força de trabalho ${ }^{32}$ (ver tabela 2), de um processo já intenso de favelização e com uma grave crise inflacionária. Além disso, um ritmo de crescimento ainda acelerado dos centros urbanos, com característica de espraiamento da mancha urbana como resultado, sobretudo, do modelo rodoviário adotado pelo país (SANTOS, 2008), como parte do incentivo ao uso do automóvel e para a integração nacional, abrindo novos mercados. A forma espraiada de ocupação influenciou no crescimento do problema fundiário das cidades, suscitando especulação e segregação socioespacial.

A política habitacional do BNH teve sua importância para o Regime imposto em 1964 justamente por conseguir atingir uma camada da população brasileira já espoliada e as classes médias. O Golpe Civil-Militar aconteceu em um período de rápida urbanização e adensamento das grandes cidades brasileiras, que recebiam diariamente aportes de migrantes advindos de zonas rurais de todo o país, sobretudo em São Paulo e Rio de Janeiro.

A acelerada e desordenada expansão e adensamento dos grandes centros urbano no Brasil levou ao agravamento da questão habitacional. Levando-se em conta as devidas proporções e contextos históricos, podemos observar o comentário de Engels sobre a Alemanha do séc. XIX, revelando a relação intrínseca entre a rápida industrialização e a escassez de moradia:

A época em que um velho país agrícola passa por tal transição - e, ainda por cima, acelerada por circunstâncias tão favoráveis - da manufatura e da pequena empresa para a grande indústria é também predominantemente um tempo de 'escassez de moradia' (ENGELS, 1887, Prefácio para Sobre a questão da moradia, 2015).

Devido à ruptura repentina no poder central e as condições de exploração no trabalho e urbanas, o BNH representava uma tentativa do governo federal de dirimir descontentamentos e protestos populares. O desenho institucional e financeiro da política, no entanto, não permitiu, ou não foi estruturado para que ela alcançasse a classe trabalhadora da forma prometida, classe que compunha

\footnotetext{
${ }^{32}$ Recomenda-se aqui a leitura de Francisco de Oliveira (2011), bem como Milton Santos (2008), que caracterizam pontualmente e esclarecem a questão da desvalorização do trabalhador assalariado.
} 
o maior volume do déficit habitacional. $\mathrm{O} B N H$ tornou-se uma política voltada principalmente para as classes médias. "Em 1975, o BNH só dedicava só 3\% dos seus financiamentos para famílias com rendimentos abaixo de cinco salários mínimos" (BOLAFFI apud MEDEIROS, 2010, p. 7) e, ao final de sua atuação, teve como resultado que apenas $33,5 \%$ das unidades foram destinadas à baixa renda.

O BNH, portanto, não cumpriu metade das metas iniciais de provimento de habitação que atingisse a classe trabalhadora mais pobre. Teve seus primeiros anos com uma atuação proporcionalmente mais equilibrada para as habitações de interesse social. Porém, esse relativo equilíbrio foi sendo corrompido com o aumento da atuação do Banco nos anos seguintes. Em 1971, segundo relatório do próprio banco: "os recursos utilizados pelo Sistema Financeiro da Habitação só foram suficientes para atender a 24 por cento da demanda populacional" (BOLAFFI, 1987, p. 53). Segundo Bolaffi:

Isto significa que, seis anos após a criação do $\mathrm{BNH}$, toda a sua contribuição para atender ou diminuir o déficit que ele se propôs eliminar constituiu em que esse mesmo déficit aumentasse em 76 por cento. De acordo com as previsões do BNH, em 1971 o atendimento percentual teria sido de 25,3 por cento e, embora deva aumentar ligeiramente em cada ano até 1980, o déficit deverá exceder 37,8 por cento do incremento da necessidade. (BOLAFFI, 1987, p. 53)

. Levando-se em conta que as unidades para a faixa economicamente mais pobre da população custam sensivelmente menos que as destinadas às classes média e alta, têm-se como resultado uma porção muito pequena dos financiamentos voltados para essa população (SANTOS, 1999). Sendo que 55\% do déficit encontra-se nessa faixa de menor renda (BOTEGA, 2008).

Maricato, baseado nos pronunciamentos da direção do próprio BNH em janeiro de 1975, onde foi anunciada a reformulação do financiamento, fixa em cinco salários mínimos a renda limite para se tornar um beneficiário dos financiamentos do banco, o que excluía, portanto, a maioria da população assalariada que era a principal afetada pelo déficit habitacional (Botega, 2008, p 7).

Programas como o do BNH (Banco Nacional de Habitação, 1964-1986) constituem-se a partir da lógica de subordinação da política aos interesses do mercado "[...]acima das próprias necessidades de superar o déficit habitacional 
das camadas populares gerado pelo processo de urbanização brasileiro" (BOTEGA, 2008, p 65).

No âmbito urbano, na lacuna do atendimento ao déficit habitacional, as favelas e loteamentos irregulares apresentaram grande crescimento nesse período e poucas foram as iniciativas governamentais que amenizaram os problemas desse tipo de ocupação (VALLADARES, 1983), como programas de urbanização de favelas (MEDEIROS, 2010). Na questão da infraestrutura, apesar de ser um dos objetivos da política urbana do desenvolvimentismo militar, os recursos do $\mathrm{BNH}$ foram mal direcionados, deixando as periferias pobres de lado em detrimento de obras que beneficiaram as porções já estruturadas do território (BOLAFFI, 1982; MEDEIROS, 2010).

Os problemas urbanos foram, em grande medida, agravados. O modelo rodoviário adotado associado ao Milagre Econômico, visando um "Brasil potência" através da expansão do capital pela integração nacional e abertura de novos mercados, mas sustentado pelo arrocho salarial, impediu bons resultados em relação ao desenvolvimento urbano, consolidando uma situação oposta. Tal modelo foi essencial na expansão da malha urbana e, concomitante aos investimentos em infraestrutura voltados às porções já privilegiadas e estruturadas das metrópoles, fez com que a especulação imobiliária crescesse e, como resultado, o processo de periferização, de ocupações ilegais e autoconstruções aumentaram e a infraestrutura urbana permaneceu sobrecarregada.

Com a habitação social localizada fora do tecido urbano, de um modo geral, o BNH e seu sistema financeiro não só contribuíram para segregar as camadas sociais de menor renda, como impediram o mercado de terras urbanas, potencializado pelos recursos do financiamento residencial oriundos da poupança privada (Sistema Brasileiro de Poupança e Empréstimo - SBPE) e da poupança compulsória (Fundo de Garantia por Tempo de Serviço - FGTS), de operar de forma sustentável (MARICATO, 2011b, p. 11-12).

Como resultado mais direto da atuação do BNH podemos citar: o incremento na especulação imobiliária, através tanto da distribuição desigual de recursos, quanto pela pressão exercida no mercado (SANTOS, 2008, p.107); o aumento da segregação pela localização da implantação dos conjuntos habitacionais (CANO, 2011, p. 204); a verticalização das áreas residenciais 
centrais (MARICATO, 1997, p. 22) e; a periferização e favelização decorrentes da especulação e das dificuldades de acesso à terra urbanizada. Dessa forma, a implementação do BNH foi realizada "[...] agravando os problemas de isolamento social e induzindo à constituição de padrões de sociabilidade muito negativos" (MARQUES, SARAIVA, 2005, p. 270). Segundo a pesquisadora Raquel Rolnik (2015, p. 267): "Não surpreende que o direito à moradia e, num sentido mais amplo, o direito à cidade tenham se tornado uma das mais importantes demandas dos movimentos sociais e de outros atores progressistas no processo de democratização que seguiu os anos da Ditadura Militar".

Com o fim de um ciclo nacional-desenvolvimentista e início do processo de redemocratização do Estado, o BNH tem suas atividades definitivamente encerradas em 1986, sendo incorporado pela Caixa Econômica Federal. O Estado encontra-se, então, sob sérias dificuldades financeiras herdadas da política econômica adotada pelos militares. Por um lado, a década de 1980 fica conhecida pela ótica econômica em grande parte conservadora ${ }^{33}$ e, por outro, é a década na qual ganham destaque pautas ligadas aos movimentos sociais urbanos e se avultam os debates acerca dos rumos políticos e institucionais do país. Assim, na década de 1980, havia um espaço político em disputa, destacando-se duas narrativas opostas: a) dos movimentos sociais envolvidos com a redemocratização e da população em geral, que apontavam os problemas agravados na ditadura e reivindicavam a ampliação de direitos sociais e acesso a bens e serviços públicos (até então usufruídos por uma pequena parcela); b) das elites econômicas e políticas, que, inspiradas na cartilha neoliberal, apregoavam a diminuição do Estado como forma de torná-lo mais "leve" e "eficaz".

Concomitantemente, com a democratização e a descentralização do poder, as cidades ganham maior autonomia. Isso permite com que algumas delas tenham períodos de experiências positivas no campo dos direitos sociais, como no governo de Luiza Erundina (1989-1992), em São Paulo, quando emergem os mutirões autogestionados para a construção de moradias de

${ }^{33}$ Certamente houve problemas e momentos de retração econômica, mas naquele período, o país não acompanhou as políticas neoliberais, e sob essa ótica seria uma "década perdida". 
interesse social. Segundo Rolnik (2015), outras iniciativas urbanas "inovadoras" foram tomadas com base na Agenda pela Reforma Urbana, retomada com o processo de redemocratização do país. Dentre as iniciativas, Rolnik (2015) aponta para participação popular direta em conselhos decisórios, programas de regularização, dentre outras. A mesma autora afirma que, contudo, essas iniciativas permaneceram "muito limitadas, em razão da frágil base fiscal dos governos locais e dos cortes drásticos nos repasses do governo federal" (ROLNIK, 2015, p. 270). Mesmo combatidas pelas elites urbanas e grande mídia local de cada cidade, as iniciativas inovadoras e populares sustentaram a pauta da agenda pela reforma urbana e congregaram movimentos e militantes na construção de uma base política que teve como resultado a eleição do PT em 2002 para o governo nacional. Além disso, foram responsáveis também por propostas de programa e agenda política alternativas (ROLNIK, 2015, p. 270)

A esperança depositada na Constituição de 1988 (a Constituição Cidadã) para a instauração de instrumentos e políticas voltadas à provisão de direitos e serviços pelo Estado contrasta com a crise econômica e com a ascensão de governos pautados pelos ideários neoliberais (ou com políticas e ações que se aproximaram desse tipo de política econômica), como o governo Collor (PRN, 1990-1992). Com a ascensão do pensamento neoliberal, inicialmente com a eleição de Fernando Collor (1989) e depois com a eleição e reeleição de Fernando Henrique Cardoso, para presidente (1995 / 2002), o Estado funciona como um agente que visa "lubrificar a máquina econômica" (ROUGIER apud DARDOT; LAVAL, 2016, p. 87).

A gestão do Estado passa a ter como principal frente o combate à crise econômica e à inflação, valendo-se de privatizações e acenando ao mercado internacional a abertura da economia. O mercado imobiliário e o financiamento habitacional ficam estagnados. A universalização de serviços e direitos sociais não tem prioridade e a política urbana passa por um período de estagnação até os anos 2000, com a retomada do crescimento econômico e das taxas de emprego, aumentado as contribuições ao FGTS, fonte de recursos para a HIS (ROLNIK, 2015). Há também a criação do Ministério das Cidades, em 2003, e 
uma crescente atenção para a construção de uma política habitacional de abrangência nacional.

A primeira sinalização de que a política habitacional não seria alavancada no governo Collor se deu com o confisco das cadernetas de poupança, comprometendo o FGTS, principal fonte de recursos para a promoção da HIS. Houve ainda no governo Collor uma tentativa de construção de HIS em caráter emergencial envolvendo empresas privadas, o Plano de Ação Imediata para a Habitação, que não foi realizado (AZEVEDO, 1988, p. 85).

Com o impeachment de Collor (1992), Itamar Franco (PMDB, 1992-1993) assume sob a responsabilidade de dar estabilidade política e econômica ao país. Em seu curto mandato, Itamar realiza modificações na política habitacional e instaura dois planos semelhantes para as HIS: o Plano Morar Município e o Habitar Brasil, voltados aos municípios com menos e com mais de 50 mil habitantes, respectivamente. Apesar de representarem avanços no desenho institucional, estes programas tiveram pouco impacto sobre o déficit habitacional ou no desenvolvimento urbano.

Em 1995 Fernando Henrique Cardoso (PSDB, 1995-2002) assume a presidência da República. No campo da política urbana, implementou a Secretaria de Política Urbana dentro do Ministério do Planejamento e Orçamento. Sua política habitacional, mesmo que de maior efetividade com relação aos seus antecessores imediatos, não obteve grande amplitude e pouco inovou nas implantações das HIS.

FHC demonstrou avanços no sentido da articulação entre diferentes esferas governamentais para o provimento de habitação, sobretudo a partir da pressão de movimento de luta por moradia digna. Contudo, a aproximação de seu governo com o ideário neoliberal resultou em uma diminuição do campo de atuação estatal em políticas urbanas, dentre elas as relacionadas à habitação de interesse social. A política habitacional se vê atrelada ao capital internacional quando o Programa Habitar Brasil passa a receber financiamento do Banco Interamericano de Desenvolvimento, o BID. Apesar de ter lançado um pacote de programas, Carta de Crédito Associativo, Apoio a Produção, Carta de Crédito 
Individual (Aquisição, Reforma e Construção), além de um Programa exclusivo para órgãos públicos, o Pró-Moradia, a promoção da habitação permaneceu em grande parte restrita ao mercado privado, sem nenhuma efetividade em relação a regulação da terra urbana, e a financiamentos voltados à classe média e as camadas sociais a partir de 3 Salários mínimos (com exceção do Pró-Moradia, que de todo modo, teve um desempenho muito baixo), não atingindo ainda as classes sociais de menor renda. Em seu último ano de mandato, $\mathrm{FHC}$ destinou cerca de 7 bilhões de reais ao SBPE e FGTS, principais fundos de recursos para a habitação no Brasil (MARICATO, 2011b, p. 65).

O período de privatizações e recuo do Estado com relação às políticas urbanas tem sua mudança em 2003, com o início da gestão de Lula (PT, 20032010). Ainda em 2003 é criado o Ministério das Cidades, responsável então pelo desenvolvimento de política habitacional condizente com o tamanho da problemática urbana. Apesar de representar uma ruptura às privatizações e aos governos anteriores, as gestões petistas (2003-2016, incluindo o primeiro e o interrompido segundo mandato de Dilma Roussef) deram, em parte, continuidade à política neoliberal, adotando também o tripé macroeconômico de superávit primário, câmbio flutuante e controle da inflação. Alves (2013) chama de neodesenvolvimentismo a articulação entre um Estado mais forte e de maior ação em políticas públicas e sociais focadas, com políticas de características neoliberais. Ainda segundo Alves (2013, s/p), "apesar do caráter pós-neoliberal da intencionalidade política do governo Lula, preservou-se a morfologia política e social do Estado neoliberal no Brasil, herdado da ditadura militar e dos governos neoliberais".

Inicia-se um período de pacificação dos movimentos políticos, por meio da negociação de conflitos, e de gradual mercadorização de direitos sociais, principalmente por meio de ações e políticas públicas alinhadas aos anseios do mercado, tais como: o ProUni (Programa Universidade para Todos), responsável pelo crescimento exponencial das universidades particulares no país, transferindo parte do direito à educação superior ao mercado; e o PMCMV (Programa Minha Casa Minha Vida) que, como veremos a seguir, foi o carrochefe no combate à crise econômica de 2008, com raízes nos mercados 
financeiro e imobiliário, e cujas moradias, como disse Milton Santos sobre a produção de HIS no Brasil, continuam nascendo "subnormais" (SANTOS, 2014, p. 62).

\subsection{MCMV: habitação, segregação e mercado}

A partir da criação do Ministério das Cidades (MCidades) em 2003 - um marco para a política urbana no Brasil contemporâneo, junto com a Constituição de 1988 e o Estatuto da Cidade (lei n 10257 de 2001) - tem-se a confluência de diferentes políticas visando uma abordagem territorial dos problemas urbanos. Assim o Ministério das Cidades procurou a articulação entre o governo federal e os municípios a fim de promoverem programas que auxiliassem as cidades em suas atribuições locais, como o saneamento e o transporte, que são essenciais na compreensão da cidade em sua totalidade. Apesar de avanços, sobretudo nos métodos de desenvolvimento de políticas, contando com participação do Conselho das Cidades (o ConCidades), o Ministério teve sua atuação subordinada à política de articulações partidárias (MARICATO, 2011b, p. 42) e foi gradualmente esvaziado na construção democrática das políticas e na compreensão global da problemática urbana.

Para a política habitacional, o governo Lula viu aprovada a lei $11.124 \mathrm{em}$ 2005, que dava origem ao Fundo Nacional de Habitação de Interesse Social (FNHIS). Essa lei teve origem nos movimentos sociais de luta por moradia ainda na década de 1990. Sua aprovação representaria um avanço no envolvimento de grupos sociais e políticos e diferentes esferas governamentais, e tinha como propósito a provisão de habitação digna à população de menor poder aquisitivo. A efetivação do Fundo, contudo, não foi prioridade para o governo Lula e não se pode afirmar que os movimentos sociais se articularam na consolidação do FNHIS como ferramenta de provisão de HIS, tendo em vista disputas dos recursos (MARICATO, 2011b, p.56). Com sua efetivação tutelada pela política orçamentária de controle de gastos e investimentos públicos, o Fundo Nacional de Habitação de Interesse Social teve seus recursos de 2006 a 2008 destinados basicamente para a elaboração de Planos de Habitação nos municípios (ROLNIK, 2015, p. 298) 
Outras importantes medidas legislativas foram: a) a obrigatoriedade de destinação de parte das verbas do SBPE (Sistema Brasileiro de Poupança e Empréstimos) e do FCVS (Fundo de Compensação das Variações Salariais) ao financiamento imobiliário (ROLNIK, 2015, p. 289); b) a garantia da alienação fiduciária que, segundo Maricato (2011b, p. 60), poderia levar o mercado imobiliário a dirigir parte de sua atenção às classes médias e; c) uma resolução do Conselho Gestor do FGTS que "permitiu ampliar os subsídios oferecidos pelo governo federal", praticamente dobrando o orçamento para habitação (ROLNIK, 2015, p. 290). Essas medidas foram tomadas entre 2004 e 2005 junto a outras com implicações para o financiamento e mercado imobiliários (MARICATO, 2011b, p.59).

O MCidades foi responsável ainda pelo Projeto Moradia, realizado a pedido do presidente Lula e que procurava articular a HIS com as políticas fundiária e urbana (MARICATO, 2011b, p. 55), tendo em vista a relação intrínseca entre elas. Não se pode procurar uma solução realmente eficiente na questão habitacional sem se alterar a estrutura jurídica e de aplicação das leis fundiárias nos municípios; assim como a habitação é central na problemática urbana, sobretudo em regiões metropolitanas.

Rolnik (2015, p. 295) afirma que o programa já havia iniciado seu desenvolvimento ainda antes da posse do presidente Lula, fazendo parte de um conjunto de políticas denominado Instituto Cidadania. O Projeto Moradia foi ainda discutido nos Conselhos de Habitação e incorporado em quase todos os itens ao Plano Nacional de Habitação (PNH) de 2004. Segundo Maricato (2011b), o Ministério das Cidades encomendou o desenvolvimento do Plano Nacional de Habitação (PlanHab), desenhado para realizar a articulação entre as questões fundiária, urbana e habitacional. O Plano foi finalizado em 2010, mas, antes que pudesse ter sua efetivação foi sobreposto pelo PAC (Programa de Aceleração do Crescimento, de 2007) e pelo PMCMV lançado em 2009.

Cabe atentar para o fato de que esses dois programas foram os maiores responsáveis diretos pela reconfiguração do tecido urbano de diversas cidades e que, apesar disso, foram gestados fora do MCidades. Ambos nasceram na Casa Civil em 2007 e 2009, respectivamente, e foram posteriormente realocados 
para o Ministério do Planejamento, Orçamento e Gestão. Tiveram como narrativa principal a provisão de serviços e direitos sociais essenciais que há muito eram negados à grande parte da população, como acesso ao saneamento adequado e à moradia.

O país chega a 2009, então, com um quadro de gradual e expressivo aumento de recursos destinados à habitação. Segundo Maricato (2011b, p. 6061), foram destinados à habitação um montante de 68,5 bilhões de reais entre 2003 e 2009, impactando mais de 3,6 milhões de famílias. Cabe ressaltar que o PMCMV foi elaborado logo após a crise econômica de 2008, que teve seu início no capital financeiro imobiliário norte-americano de hipotecas em outubro daquele ano. Dessa forma, o PCMV teve como um de seus principais objetivos se constituir enquanto uma política anticíclica, injetando recursos em um mercado com grande cadeia econômica e capilaridade em todo o país. Além disso, a construção civil é a responsável pela contratação de mão-de-obra pouco ou não especializada, e por isso poderia ter um grande impacto positivo sobre as taxas de emprego.

A narrativa oficial, contudo, apregoava a prioridade de combate ao déficit habitacional, que indicavam o número de 5,19 milhões de famílias (segundo o IPEA, Instituto de Pesquisa Econômica Aplicada) que tinham a mudança para uma moradia digna como necessária em 2008. Assim como à época do $B N H, o$ MCMV parte da compreensão (pelo menos em sua narrativa) de que o déficit habitacional está vinculado com uma "demanda reprimida" de moradias a serem construídas e com a ineficácia do mercado imobiliário de alcançar a população de menor renda. Releva-se o fato de haver mais moradias desocupadas do que pessoas precisando de moradia.

Cabe-nos ressaltar que mesmo a questão do déficit habitacional tem sido manipulada de forma a gerar números que possam ser ideologicamente utilizados no campo político (TONIN, 2015). O déficit, diferentemente da demanda por habitações, muda dissimuladamente o foco do principal fator que determina o problema habitacional no país, qual seja, o controle monopolista das terras urbanas, geridas como raridades (concentração fundiária, especulação imobiliária). Como nos mostra Rizek (2017, p. 12), o déficit, assinalado pelo 
governo no período de implementação do MCMV, ignora "a quantidade de imóveis vazios em áreas metropolitanas"34. Ignora até mesmo os números de composição do próprio déficit, como o aumento do ônus excessivo com aluguel (Tabela 01), o que demonstra claramente que o problema da habitação está ligado com os custos estipulados pelo mercado imobiliário e, consequentemente, diretamente ligado ao acesso à terra urbanizada. Segundo Luiza Souza ${ }^{35} \mathrm{da}$ Fundação João Pinheiro (instituição responsável por estudos de déficit habitacional há duas décadas), o ônus excessivo com o aluguel tende a "se acentuar ainda mais nos próximos anos, principalmente com a crise recente".

Tabela 01 - Déficit habitacional decomposto, em milhões, com destaque para o Ônus excessivo com o aluguel.

\begin{tabular}{|c|c|c|c|c|c|c|c|}
\hline & 2008 & 2009 & 2011 & 2012 & 2013 & 2014 & 2015 \\
\hline $\begin{array}{l}\text { Habitações } \\
\text { precárias }\end{array}$ & 1,139 & 1,074 & 1,163 & 0,870 & 0,997 & 0,863 & 0,924 \\
\hline Coabitação & 2,307 & 2,032 & 1,808 & 1,757 & 1,905 & 1,911 & 1,757 \\
\hline $\begin{array}{l}\text { Onus excessivo } \\
\text { com aluguel }\end{array}$ & 1,735 & 2,020 & 2,110 & 2,293 & 2,553 & 2,926 & 3,189 \\
\hline $\begin{array}{l}\text { Adensamento e } \\
\text { aluguel }\end{array}$ & 0,500 & 0,539 & 0,512 & 0,510 & 0,390 & 0,366 & 0,314 \\
\hline $\begin{array}{l}\text { Déficit habitacional } \\
\text { total }\end{array}$ & 5,191 & 5,703 & 5,409 & 5,244 & 5,846 & 6,068 & 6,186 \\
\hline
\end{tabular}

Fonte: PNAD/IBGE (2008 a 2012) e FJP (2013 a 2015)

Mesmo se utilizarmos somente os dados oficiais do governo, há uma discrepância entre o número de moradias construídas e o saldo do déficit nos anos de vigência do MCMV. Dessa forma, visando ainda a utilização políticopublicitária do PCMV, o governo federal instituiu um novo índice para o cálculo de déficit habitacional, no qual faz-se a proporção entre as unidades habitacionais totais do país e a demanda de famílias por moradia, criando-se o "déficit habitacional relativo". Nesse caso, o número do déficit relativo apresentou pequena queda desde a implementação do PMCMV até o ano de 2013, período

\footnotetext{
${ }^{34}$ No Brasil, em 2014, havia mais de 5,7 milhões de domicílios vagos em condições de serem ocupados apenas em áreas urbanas, segundo estudo da Fundação João Pinheiro. Ver mais em: Fundação João Pinheiro. Déficit habitacional no Brasil 2013-2014. Belo Horizonte: FJP, 2016. ${ }^{35}$ Visto em: <http://www.fjp.mg.gov.br/index.php/fjp-na-midia/3785-1-3-2017-deficithabitacional-aumenta-com-a-recessao> Acesso em: 03 dez. 2017.
} 
de maior produção do programa e que antecedia as eleições presidenciais de 2014. O índice relativo pode ser contestado se levarmos em conta que o setor da construção civil teve grande aporte de recursos e esteve aquecida nos anos 2000, o que pode explicar parte do aumento do número de domicílios construídos e com isso a queda do déficit habitacional relativo (Tabela 02).

Tabela 02 - Déficit habitacional relativo

\begin{tabular}{|l|c|c|c|c|c|c|c|c|}
\hline & 2007 & 2008 & 2009 & 2011 & 2012 & 2013 & 2014 & 2015 \\
\hline Déficit hab. relativo & $10,4 \%$ & $9,4 \%$ & $10,1 \%$ & $9 \%$ & $8,5 \%$ & $8,9 \%$ & $9,1 \%$ & $9,3 \%$ \\
\hline
\end{tabular}

Fonte: Fundação João Pinheiro, 2017

Em 2009 o PMCMV foi, então, gestado como política pública voltada ao mercado imobiliário. O cenário econômico para as grandes empresas da construção civil no país em 2008 apontava para possibilidades de quebras, o que de fato veio a acontecer em alguns casos. Isso se deu por conta da descapitalização das empresas que tiveram a abertura de capitais no início dos anos 2000. Estas empresas adquiriram estoque de terrenos (landbanks) e, com a crise de 2008, "encontraram dificuldade para sustentar a produção em seguida, e parte apresentou dificuldade para escoar o excesso de produção" (MARICATO, 2011b, p. 63).

Ainda segundo Maricato (2011b, p. 63), 11 das 25 empresas que abriram seus capitais na Bolsa de Valores de São Paulo participaram da elaboração do PMCMV e por isso, certamente, o programa foi desenhado também a partir das pretensões desse empresariado. Já em 2014, 9 das 22 empresas com capital na Bovespa "concentravam 100 bilhões de reais em terra, o que representa 620 mil quilômetros quadrados de solo urbano, em várias cidades do país" (ROLNIK, 2015, p. 292), apontando para a concentração fundiária e para uma crise habitacional distante de ser verdadeiramente combatida.

Segundo Mariana Fix (apud ROLNIK, 2015, p. 300), o governo federal propôs a compra de ações de empresas do setor, o que foi rechaçado por elas. O setor imobiliário passa, então, a fazer lobby requisitando apoio do governo para a produção de habitação de baixo custo em condições favoráveis às empresas. Segundo Rolnik (2015, p. 300), o lobby e as negociações se deram 
no interior do Ministério da Fazenda, sem a participação do MCidades, do Conselho das Cidades ou da equipe do Plano Nacional de Habitação.

Com o MCMV há um forte aporte de recursos para o setor imobiliário do país. O Programa procura, então, destinar seus recursos para as famílias com renda de até 5 mil reais (em 2009), com prioridade para as famílias com renda de 0 a 3 salários mínimos (1,6 mil reais em $\left.2009^{36}\right)$. As unidades são construídas de forma rápida para os padrões brasileiros de HIS, de forma que o Programa pôde ser usado como plataforma política para a eleição seguinte, na qual o volume de recursos destinados (cerca de 240 bilhões de reais) e de unidades construídas até então (cerca de 2 milhões) foi publicitariamente explorado.

Inicialmente o MCMV seria realizado apenas em regiões metropolitanas e cidade com mais de 100 mil habitantes, tendo em vista que nelas se encontram as maiores demandas por habitação, como já citado. Contudo, durante o processo de aprovação da lei que institui o Programa, os deputados com base eleitoral em cidades menores pressionaram pela mudança e, assim, o MCMV passou a atender também cidades com menos de 50 mil habitantes (ROLNIK, 2015, p. 302). O processo de aprovação ainda contou com rodadas de negociação com movimentos sociais de luta por moradia e pela reforma agrária. O resultado das negociações foi a ampliação do Programa e a criação de categorias específicas para as demandas desses grupos, como o MCMV Entidades e o PNH Rural (ROLNIK, 2015). Imediatamente após o lançamento do MCMV, as principais empresas do ramo imobiliário com ação na Bovespa recuperaram seus valores de mercado (ROLNIK, 2015, p. 304-305). Articulandose o PCMV com o Bolsa Família ${ }^{37}$, a intenção inicial do governo federal era constituir as bases para a cidadania de famílias que até então viviam em condições de precariedade de moradia e renda, respectivamente. Grande parte das famílias moradoras dos apartamentos e casas construídas pelo PCMV contam também com o auxílio do Bolsa Família e em ambos os programas as

\footnotetext{
${ }^{36}$ Salário mínimo de $\mathrm{R} \$ 465,00$ em 2009, Lei 11.944/2009.

${ }^{37}$ Programa de distribuição de renda responsável por uma grande reconfiguração da economia de pequenos municípios e, principalmente, para a vida de mulheres e suas famílias beneficiárias, como poderemos ver adiante neste trabalho. Ver mais em Walquíria Rego, 2013.
} 
mulheres das famílias detêm a titularidade do cartão e da habitação. Desta forma, os programas tiveram um impacto forte sobre a vida de mulheres até então dependentes de seus companheiros, sobretudo as que sofriam de violência doméstica ou não queriam permanecer junto a eles por qualquer motivo. A articulação dos programas resulta ainda na possibilidade das famílias se consolidarem em um endereço e seu entorno, algo incomum para parte das famílias que viviam sob a insegurança de permanência ou não na moradia e/ou que apresentavam longa trajetória de mudanças de local de moradia ou ocupação, como mostrado por Thaís Rosa (2014). Ademais, o MCMV conseguiu em grande parte vencer uma importante barreira para o acesso aos serviços básicos que são, em tese, direitos universais, tais como à saúde e educação (em implantações com esses equipamentos ou próximas a eles).

O acesso à casa própria para as famílias cadastradas junto às Secretarias de Assistência Social dos municípios (ou semelhante) se deu através do financiamento da habitação junto à Caixa Econômica Federal. As famílias de menor renda, pertencentes à Faixa 1 do Programa, recebem uma moradia com subsídio governamental chegando a até $90 \%$ do valor do imóvel. O financiamento é pago em prestações pequenas de modo a não comprometerem a renda familiar, tendo em vista que o déficit habitacional tem no comprometimento excessivo da renda com o aluguel o seu maior índice. As parcelas eram fixadas em $5 \%$ da renda familiar e, posteriormente, designou-se que as prestações para as famílias da Faixa 1 seriam de 50 reais mensais.

Apesar dos baixos valores das prestações do financiamento, muitas famílias se encontraram em situação financeira difícil decorrente do comprometimento da renda com outras despesas que antes não compunham o cotidiano delas, como contas de condomínio, gás, água e luz, podendo chegar a $77 \%$ de comprometimento da renda mensal, segundo estudo elaborado pelo Instituto Pólis, LabCidade (FAU-USP), PUC-SP e IAU-USP (apud ROLNIK, 2015, p. 315). Por isso o Programa recebeu o apelido crítico de "Minha Casa, Minha Dívida"38. Cabe lembrar que parte das famílias participantes do programa

${ }^{38}$ Como pode ser visto em: <http://economia.estadao.com.br/noticias/geral,aqui-devia-sechamar-minha-casa-minha-divida,1765398> Acesso em: 12 dez 2017. 
estavam em situação de ocupação ou em moradias cujo abastecimento de água e luz eram realizados através de "gatos", arranjos ilegais na rede pública de distribuição desses serviços.

O caminho mais comum para receberem a moradia foi o cadastro junto às prefeituras municipais nas Secretarias de Assistência Social. Outras formas foram intermediadas por movimentos sociais de luta por moradia, por algumas ONG (algumas originalmente não ligadas à pauta da habitação popular) ou diretamente pelo poder público no caso de remoções. Operam-se, assim, formas despolitizadas de requerimento do acesso ao direito à moradia. Este direito passou a ser visto como um benefício, obedecendo também à linguagem oficial do governo, que se refere aos moradores dos MCMV como "beneficiários" não só deste, mas de outros programas com amplitude social implementados pelo governo federal na era petista. Assim como em outras políticas habitacionais, novamente confunde-se o direito à moradia com o direito de ser proprietário (SANTOS, 2014, p. 154)

Esse foi o panorama geral de implantação do Programa na esfera institucional e pública. Não é escopo deste trabalho aprofundar nas questões institucionais e nas subdivisões e evoluções características do Programa ao longo de seus 8 anos de funcionamento até então (ao final de 2017); sobretudo se tomarmos para análise as recentes alterações perpetradas pelo atual governo, responsável pelo desmanche do MCMV em sua vertente que provia habitação para as famílias de faixa de mais baixa renda.

Com relação à construção das moradias, de modo geral obedecem a uma variedade de modelos: em conjuntos habitacionais abertos, fechados (na tipologia condominial); em larga escala ou em escala menor (conjuntos com dezenas de apartamentos ou casas contrastando com implantações que chegam às milhares de habitações); horizontalizados ou verticalizados; com ou sem a implantação de equipamentos públicos de lazer, saúde e educação; próximos ou distantes da malha urbana consolidada e dos meios de transporte. Mesmo que as implantações das moradias obedeçam a diferentes combinações entre essas características, encontramos em comum entre elas a falta de qualidade arquitetônica e urbanística e a ausência de participação dos moradores nos 
processos relativos à implementação e construção das moradias (salvo exceções, como algumas da modalidade MCMV Entidades, sendo essa a modalidade que recebe o menor volume de recursos, menos de $1 \%$ do total ${ }^{39}$ ).

O poder decisório sobre a localização dos empreendimentos ficou a cargo, sobretudo, das empresas construtoras. Visando a rentabilidade na construção dos empreendimentos, as empresas não tinham como fator preponderante a urbanidade, as qualidades arquitetônicas e urbanísticas, a localização que não gerasse ônus e tempo excessivos com transporte, como exemplos. Dessa forma, os empreendimentos nasceram fadados a apresentarem problemas de diversas naturezas e ordens. Segundo Maricato (2011b, p. 68-69), ao analisarmos a proposta do Programa, sabendo-se das características da experiência de provimento de HIS na Ditadura Militar:

(...) foi possível prever o que a experiência recente já mostra: o impacto negativo sobre as cidades devido à localização inadequada de grandes conjuntos habitacionais e ao aumento do preço da terra e dos imóveis.

A maior parte da localização das novas moradias - grandes conjuntos sendo alguns, verdadeiras cidades - será definida nos municípios e metrópoles, por agentes do mercado imobiliário sem obedecer a uma orientação pública, mas à lógica do mercado. Não podemos afirmar que prefeituras e governos estaduais garantam, usualmente, melhores localizações. Essa não tem disso a regra.

A localização em terras urbanas (ou urbanizáveis) e a padronização dos tipos arquitetônicos em cada conjunto que conferiam lucros às empresas, além da rapidez e racionalização do canteiro de obras. Assim, as moradias foram dispostas sem estudos das condicionantes ambientais locais, como insolação e ventilação; sem cuidados quanto à implantação dos equipamentos, dispondo-os nas porções do terreno que gerariam menores custos; sem se levar em consideração os arranjos familiares mais comuns e a cultura de extensão da residência para abrigar o crescimento da família e, ainda menos, arranjos familiares particulares; não houve preocupação, de modo geral, com as relações de vizinhança anteriores; e não houve, de modo geral, a participação das famílias em decisões arquitetônicas ou urbanísticas quanto às moradias e aos

${ }^{39}$ ROLNIK, 2015, p. 302. 
empreendimentos. Parte dos empreendimentos desconsideraram ainda a possibilidade de implantação de serviços como mercados e farmácias, obrigando os moradores a deslocamentos para realizarem suas compras ou, como é comum, a improvisação de mercadinhos e bares nas garagens e quintais das moradias.

De acordo com o parâmetro da lucratividade, "observa-se a aglomeração de diversos empreendimentos em uma mesma região, formando verdadeiros bolsões de moradia popular, bastante semelhantes às cidades-dormitório que foram constituídas pela produção habitacional pública em décadas anteriores" (ROLNIK, 2015, p. 311). Assim como Raquel Rolnik (2015), outras(os) pesquisadoras(es) têm alertado para a latente segregação perpetrada pelo Estado por meio do MCMV (MARICATO, 2011b; SHIMBO, 2010; PEQUENO, 2015; ROLNIK, 2015; entre outros).

(...) primeiro, por conta de uma localização em que o direito à cidade não é garantido, ou seja onde a acessibilidade às redes de infraestrutura e aos serviços urbanos sejam negados; em seguida, quanto a sua localização periférica, complementando espaços residuais ou mesmo abrindo novas frentes de expansão, observa-se o agravamento da segregação pela fragmentação territorial e pela vulnerabilidade socioambiental; por fim, a abordagem se dá pela homogeneidade do tecido social produzido, onde os efeitos perversos da monofuncionalidade e da guetificação se entrelaçam e atingem de modo nefasto aqueles que foram deslocados para estas áreas." (PEQUENO, 2015, p. 9-10, grifos meus).

O MCMV, portanto, agudiza o problema da segregação socioespacial e dos espaços monofuncionais já verificados no período do BNH. Reforça também os padrões segregacionistas de ocupação do território, pois os empreendimentos verticais são, obrigatoriamente, cercados e fechados em si. Ademais, muitos dos empreendimentos horizontalizados também se fecharam no formato de condomínios, criando novas áreas de desconexão entre as pessoas e a malha e vivência urbanas. Mesmo em conjuntos habitacionais horizontais e de pequeno porte se observa que a primeira modificação realizada pelos moradores é murar suas divisas, inspirados na narrativa da insegurança midiatizada cotidianamente. 
Como nos apontou Lefebvre (1971, p. 176, tradução minha): "Nos grandes conjuntos urbanos, e sem que nada ajude a frear uma certa potência negativa (a da análise, unida a da tecnicidade), a segregação levada a suas últimas consequências está na ordem do dia".

Não cabe a este trabalho fazer um levantamento dos pontos positivos e negativos do Programa, desde os seus antecedentes históricos e políticos, passando pelo desenho institucional até a aplicação do Programa e construção das moradias em todo o país. Certamente o MCMV como um programa desenvolvido por um conjunto de agente técnicos e políticos de diferentes áreas e com diferentes interesses vai resultar em longas listas de pontos positivos e negativos - mais negativos, como apontamos. Procuremos, então, pensar em como os principais desses pontos trabalham em conjunto, ou seja, compondo um sistema de contradições e conflitos internos inerentes e que, apesar disso, funciona. Como veremos nas partes finais desta pesquisa, o MCMV quando construído gera ainda novas situações, conflitos e contradições entre seus moradores, reafirmando a complexidade da problemática habitacional e, concluiremos, as relações com os territórios que esse tipo de política não pode ignorar, como infelizmente se mostra a realidade do Minha Casa, Minha Vida em seus anos de aplicação.

Podemos concluir, por hora, que a questão habitacional historicamente e atualmente tem sido utilizada, sobretudo, como fator de incentivo ao mercado da construção civil e como moeda política de governança, em formatos institucionais e políticos que resultam ainda na expansão da malha urbana e no reforço à segregação socioespacial. A obviedade da necessidade humana básica de se ter uma moradia não explica, sozinha, o formato das políticas habitacionais. Deve-se entender também que a questão habitacional faz parte: i) dos custos da reprodução da força de trabalho; ii) do mercado, como um produto resultado de extração de mais-valia e, portanto, inteiramente integrado ao capitalismo; iii) das dinâmicas de valorização de terras urbanas, ou seja, da especulação imobiliária; iv) do direcionamento do crescimento urbano, através de políticas e legislações; v) das aspirações de crescimento econômico das classes de renda mais baixa; vi) das aspirações de gozo da cidadania (mesmo 
que uma cidadania mercadorizada), pois a moradia fixa possibilita o usufruto de serviços e infraestrutura urbanas. Deve-se compreender com relação à "vi" que o enraizamento das famílias em moradias pode ser também condição de estagnação e controle social, tendo em vista a experiência histórica como, por exemplo, de vilas operárias que tinham caráter disciplinador.

Portanto, tem-se como resultado do período petista (Lula e Dilma, 20032015) a utilização de um sistema no qual as políticas públicas servem para aquecer setores da economia, manter a governança, e fazer uma espécie de terceirização, já que o Estado transfere para empresas e organizações sociais os serviços originalmente de responsabilidade estatal. Têm-se no incentivo ao consumo uma das principais agendas dos governos, que acreditava no desenvolvimento econômico a partir de políticas de distribuição de renda e acesso ao crédito e a bens de consumo duráveis. Como declarou a primeira presidenta do BNH, Sandra Cavalcanti: "a casa própria faz do trabalhador um conservador que defende o direito à propriedade" (ROLNIK, 2015, p. 282).

Nas políticas públicas e sociais, observamos a "fetichização" dos números que não conseguiu se efetivar em melhorias reais, como acontece em Estados cuja gestão obedece à racionalidade neoliberal (LAVAL; DARDOT, 2016, p. 318). Dessa forma, o acesso aos direitos tem por intermédio o mercado, contribuindo para a compreensão de uma cidadania meritocrática e alcançada individualmente, destituindo o caráter coletivo e político dos fundos públicos, aqueles que dão materialidade aos direitos sociais. Acrescenta-se a negociação dos conflitos pela adoção de políticas que atendem somente em parte as "demandas sociais", arrefecendo os movimentos sociais e fazendo emergir entidades mediadoras que ocupam o lugar da participação (RIZEK, 2017)

Assim, os direitos sociais historicamente instituídos, frutos de um pacto social em constante transformação (LAVALLE, 1997), passam para a esfera burocrática empresarial e são ligados diretamente ao consumo. Para acessá-los, deve-se pagar. Desenraiza-se da esfera pública a construção desses direitos. "Quando se confunde cidadão e consumidor, a educação, a moradia, a saúde, o lazer aparecem como conquistas pessoais e não como direitos sociais" (SANTOS, 2014, p. 155). Com a individualização das políticas públicas, "é a 
própria definição de sujeito político que é radicalmente alterada" (LAVAL; DARDOT, 2016, p. 320). Reiterou-se, nos últimos anos, o "encolhimento do conflito" ao se colocar a lógica empresarial como "valor dominante e, principalmente, estruturante" (RIZEK, 2017, p. 134). 


\section{APROPRIAÇÃO E DINÂMICAS SOCIOESPACIAIS}

Este capítulo tem como objetivo demonstrar como a apropriação do espaço passa a ser objeto de análise, desenvolvimento teórico e colocada como questão à arquitetura e urbanismo sobretudo após a ascensão do pensamento modernista de inspiração corbusiana. Pretendemos mostrar algumas das principais abordagens sobre a manifesta problemática urbana, ampliada, em parte, pela prática do ideário funcionalista descrito na Carta de Atenas e na difusão do modelo de cidades-jardim (criado por Ebenezer Howard, 1850-1928).

No âmbito das críticas às compreensões e realizações da arquitetura e do urbanismo proposto pelos CIAM (Congresso Internacional de Arquitetura Moderna $^{40}$ ) do período entre guerras, sob uma pretensa "racionalidade urbanística", um dos críticos mais duros e de maior expressão foi o filósofo e sociólogo francês Henri Lefebvre (1901-1991). Tendo em vista a importância das questões urbanas desenvolvidas por Lefebvre para o presente trabalho, procuramos também apresentar parte do contexto histórico (e intelectual) do qual Lefebvre se utilizou para a formulação de sua teoria crítica, quais sejam, as cidades e sociedades submetidas à lógica industrial e, ademais, a sociedade de consumo dirigido e seu cotidiano alienado.

\subsection{Crítica à arquitetura e urbanismo funcionalistas: apropriação do espaço como questão}

Desde a ascensão das ideias dos modernismos na arquitetura e no urbanismo, com sua principal corrente ideológica sintetizada na Carta de Atenas (1933) e na figura dos CIAM, e com a sujeição desses campos da prática social a uma racionalidade funcionalista, emergem também os estudos e críticas aos espaços criados sob essa racionalidade. Os CIAM foram símbolo de uma geração que acreditava em uma linguagem arquitetônica que pudesse exprimir

${ }^{40}$ Congrès Internationaux d'Architecture Moderne. 
o espírito da "civilização maquinista", resultado das recentes transformações dos processos de industrialização e urbanização na virada do séc. XIX para o séc. XX (BARONE, 2000).

Esta racionalidade foi aplicada à arquitetura e ao urbanismo de maneira hegemônica na primeira metade do século XX e foi descrita por Lamas (2004, p. 234), mais especificamente ao urbanismo de inspiração na Carta de Atenas, como urbanística formal. A Carta procura reduzir as funções da cidade a quatro consideradas essenciais: habitação, recreação, circulação e trabalho. Por isso, sobretudo, a esta racionalidade modernista chamaremos funcionalista, abordando-a de maneira mais ampla, como o fez Lefebvre (1999), que chamou este modelo de urbanismo operatório, principalmente.

Podemos ver claramente que o movimento moderno importou para a arquitetura a lógica industrial, procurando equiparar a arquitetura para habitação e o urbanismo para a cidade com as peças para o funcionamento de uma máquina. Para tanto, a Carta tinha como instrução "dar a cada função e a cada indivíduo seu justo lugar" (RABELO et al., 2016)

Essa lógica industrial explica também a fixação pela unidade habitacional, vista como um bloco primordial no qual outros blocos se unem para, então, a partir da organização dos blocos se chegar à "cidade funcional". Procurou-se, com a habitação, "estabelecer padrões para a indústria da construção" (BARONE, 2000, p. 21). Os critérios para a habitação passam a ter quase um caráter "científico", com a busca pela "racionalização, economia e padronização" (BARONE, 2000, p. 23).

$\mathrm{Na}$ verdade, essa suposta cientificidade esconde um pensamento ideológico que credita às práticas arquitetônicas um grande determinismo social, colocando os desenhos arquitetônicos e urbanísticos como capazes de direcionar a sociedade a novos rumos.

A partir das discussões sobre a habitação, pode-se aumentar a escala e discutir a cidade funcional, tendo em vista que a organização dos blocos deveria prezar por uma organização e densidade ótimas, relacionando-os às vias de acesso, alocação e espaços livres. A "máquina de morar" e a "cidade funcional", 
segundo a crítica à Carta de Atenas, não abarcavam a compreensão das experiências urbanas reais e diversas, das culturas locais, das questões relativas ao que conforma uma comunidade (Figura 01). Como afirma Barone, a Carta de Atenas tentou renomear elementos urbanos a fim de resignificá-los, o que acabou por retirar o conteúdo concreto que esses elementos carregavam: "A habitação era chamada de alojamento, a rua era percurso, o parque era espaço verde, a rua-corredor (...) era transportada para o corredor das habitações do edifício" (BARONE, 2000, p. 35)

Figura 01: Maquete do Plan Voisin (1925) de Le Corbusier para Paris. Exemplo do pensamento corbusiano para o urbanismo modernista.

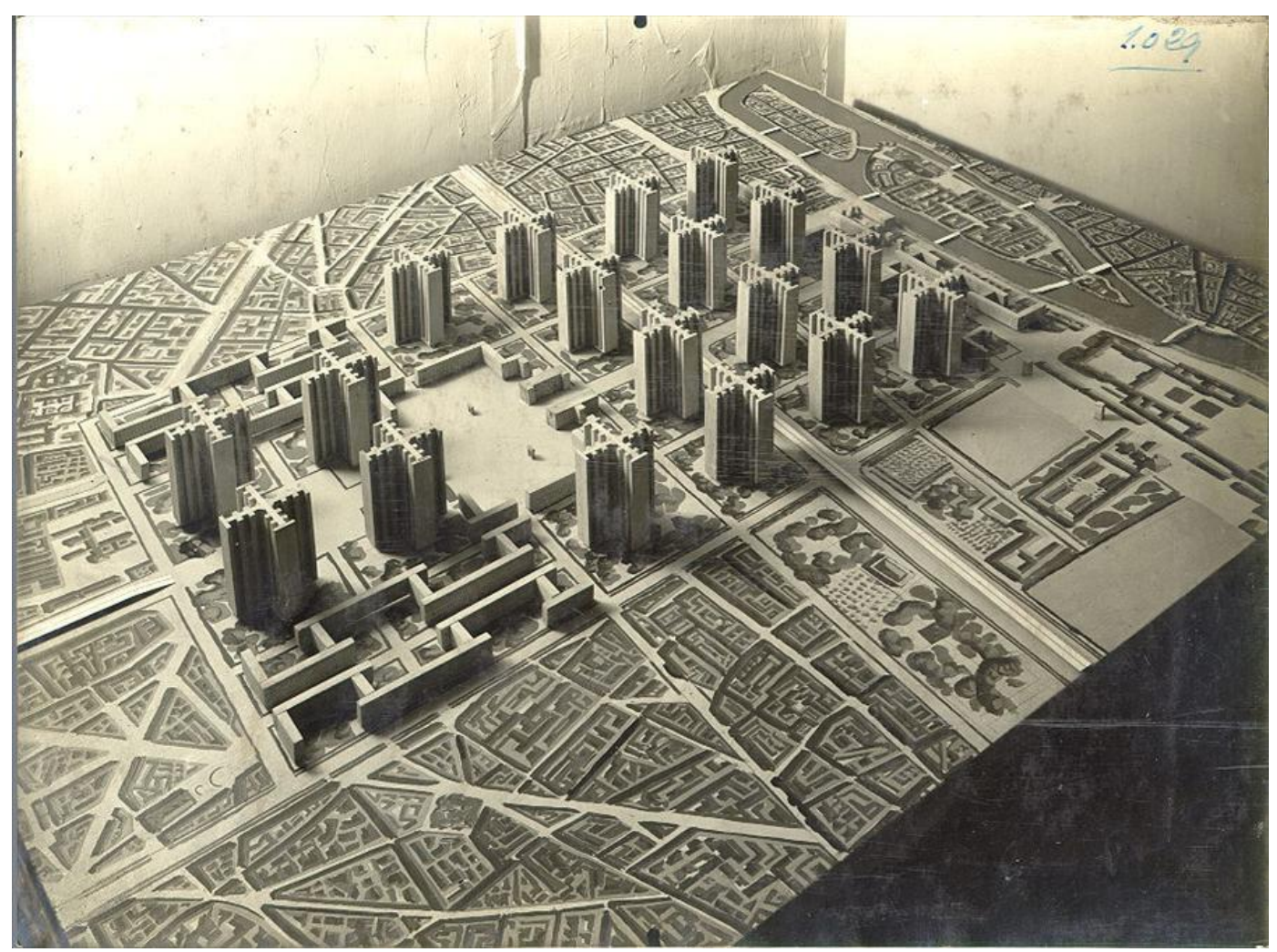

Disponível em:

<http://www.fondationlecorbusier.fr/corbuweb/morpheus.aspx? sysld=13\&/risObjectld=6159\&s ysLanguage $=$ en-en\&itemPos=2\&item Count $=2 \&$ sysParentName=Home\&sysParentld $=65>$ Acesso em: 18 ago 2017.

Contudo, o pensamento moderno ainda era predominante no pós-guerra e serviu como base para grandes projetos de arquitetura e de urbanismo. Nessa época, bairros e cidades inteiras foram construídos a partir do zero em boa parte da Europa. Na Inglaterra, apenas uma década após o fim da Segunda Grande 
Guerra, havia cerca de dez novas cidades, as New Towns ${ }^{41}$. No caso dessas cidades, observa-se a confluência de três fatores determinantes: o relativo sucesso dos subúrbios inspirados nos ideais de cidade-jardim ${ }^{42}$ de Ebenezer Howard; o desenvolvimento de processos industrializados na construção civil, impulsionados pela arquitetura modernista; e o contexto político do Estado keynesiano conhecido como Welfare State (Estado de Bem-Estar Social).

Tanto as new towns quanto outros grandes projetos de bairros e cidades, baseados nos modelos das cidades jardim ou do modernismo funcionalista, despertaram o interesse para estudos sobre a vida urbana desses locais. Mesmo dispondo de urbanismo e equipamentos de qualidade, muitos de seus habitantes apresentavam reclamações sobre a falta de urbanidade. Às cidades faltavam relações sociais, cultura e vitalidade vistas nos centros urbanos históricos. Afora isso, dizia-se que sua arquitetura era entediante, sem sentimento (HALL, 1996, p. 135). "A cidade que não tem coração" e de "planejamento perfeito e monotonia perfeita", segundo o jornalista britânico Merrick Winn (The Daily Express, 1957) 43 sobre Newton Aycliffe, uma das primeiras new town inglesa.

Foi nesse contexto que as críticas ao movimento moderno em arquitetura se agravam inclusive internamente ao CIAM, com a participação de arquitetos mais jovens, que diziam analisar o pensamento e a produção da arquitetura moderna para além do funcionalismo. Cabe ressaltar também que esses arquitetos conviveram - concomitantemente às reclamações e desconfianças sobre as new towns - com as ruas das cidades tradicionais apropriadas por crianças e jovens nascidos no baby boom do pós-guerra. Apropriações tais que levaram os dissidentes do CIAM a proporem novas formas de abordagem para as arquiteturas e espaços que proporcionavam situações de uso e apropriação. Nas palavras de um desses arquitetos da nova geração dos CIAM:

O homem pode se identificar de imediato com seu próprio lar, mas não se identifica facilmente com a cidade em que está

\footnotetext{
41 Áreas designadas para serem planejadas e construídas sob legislação aprovada pelo parlamento do Reino Unido (New Towns Act, 1946). A legislação teve duas reformulações mais importantes (New Towns Act de 1965 e de 1981).

${ }^{42}$ Modelo urbanístico largamente difundidos no séc. XX e que inspira a produção de subúrbios de classe média e alta ainda hoje.

${ }^{43}$ Visto em: <http://www.thebubble.org.uk/culture/history/new-town-blues-town-planning-20thcentury-psyche/> Acessado em : 16 ago. 2017.
} 
situado. "Pertencer" é uma necessidade emocional básica suas associações são da ordem mais simples. Do "pertencer" identidade - provém o sentido enriquecedor da urbanidade. A ruazinha estreita da favela funciona muito bem exatamente onde fracassa com frequência o redesenvolvimento espaçoso (SMITHSON, 1968 apud FRAMPTON, 1997, p. 330).

Após os embates de ideias entre o grupo mais jovem (Alison e Peter Smithson, Aldo Van Eyck, Jacob Bakema, entre outros ${ }^{44}$ ) e o grupo encabeçado por Le Corbusier (composto por Ernesto Rogers, Sert, Van Eesteren, entre outros ${ }^{45}$ ), ficou evidente que o segundo grupo estava sendo colocado à prova. Visando retomar a força de seu grupo nos CIAM, Le Corbusier propõe o tema "Habitat" para o encontro seguinte.

O tema Habitat foi sugerido pelo próprio Le Corbusier, que pretendia com isso voltar a reforçar a ideia de habitação como função social urbana primordial. Mas a geração mais jovem estava interessada em uma discussão que refletisse seus interesses na questão das relações sociais engendradas a partir do desenho do espaço urbano. (BARONE, 2000, p. 43).

O grupo de Le Corbusier considerava o Habitat a unidade habitacional, desprezando os espaços do entorno. Em contrapartida, o grupo dos mais jovens, conhecido posteriormente como Team $X^{46}$ (ou Team 10), fazia uma leitura do Habitat como uma espécie de "espaço vital", um conjunto de espaços necessários para a vida na coletividade, o que incluía, naturalmente, espaços públicos e de convívio (BARONE, 2000, p. 50).

Na mesma época (1942-1948), Le Corbusier continua sua busca pela unidade e desenvolve um conjunto de parâmetros chamados Modulor, cuja função seria a de determinar práticas projetuais para dimensões humanas universais, tomando como base um corpo - quase arbitrariamente - tido como de estatura média (1,73 metros e posteriormente 1,85 metros) que "corresponderia ao homem-padrão para habitar a sua 'cidade ideal', racionalfuncionalista" (RABELO et al., 2016). O Modulor, de certa forma, naturalizava o

\footnotetext{
${ }^{44}$ Idem, p. 329

${ }^{45}$ FRAMPTON, 1997, p. 329

${ }^{46} \mathrm{O}$ Team 10 era composto por jovens arquitetos europeus que participaram de encontros do CIAM e divergiam do pensamento funcionalista hegemônico até então. As críticas deles levaram ao fim do CIAM após o seu décimo encontro, em 1956, em Dubrovinik. Por isso, esse grupo dissidente passou a ser conhecido como Team 10.
} 
espaço produzido sob a lógica industrial de padronização imposta por intermédio do funcionalismo aos modos de viver na cidade (LEFEBVRE, 2013, p. 372)

(...) Mas qual é a realidade que sobreveio dessas novas cidades? Se você lê os jornais de nossos países, sobre o que você está lendo? Sobre uma sociedade que tem um novo padrão? Sobre uma sociedade que tem agora novas cidades? Ou você lê sobre os jovens que estão crescendo nessas cidades? Os jovens que estão vivendo nessas casas e se lavando nesses banheiros, esses são talvez os jovens mais problemáticos que nossa sociedade já teve. (BAKEMA apud BARONE, p. 61. Grifos nossos)

Observa-se, a partir da afirmação de Bakema, a centralidade da questão da juventude para as cidades, relatada por arquitetos do Team 10. Tomando a questão infanto-juvenil mais a fundo, pode-se considerar a ação transgressora desses grupos nas cidades como símbolo de uma desobediência natural e orgânica à ordem estabelecida, indo de encontro às formas propostas verticalmente pelos arquitetos e urbanistas funcionalistas. Escancara, dessa forma, o descontrole e a inadequação do funcionalismo moderno à organicidade, multiplicidade e vitalidade dos espaços urbanos "tradicionais", historicamente construídos e constituídos.

Segundo Aldo Van Eyck, um dos arquitetos de maior destaque da nova geração dos CIAM, "o funcionalismo matou a criatividade" (RABELO et al., 2016). O arquiteto foi o responsável pelos projetos de centenas de parques e playgrounds ao longo de sua carreira e despertou para a importância das "preexistências" urbanas na prática projetual já no início dos trabalhos nesse campo (OUDENAMPSEN, 2011), procurando estabelecer relações entre sua arquitetura e o ambiente no qual ela seria inserida.

Van Eyck tornou-se, posteriormente, referência na abordagem e prática para intervenção em espaços considerados residuais. Percebe-se que a preocupação em relação ao púbico infanto-juvenil, que ocupava as ruas, praças e becos das cidades, foi uma chave de mudança na abordagem de Van Eyck sobre a arquitetura que produzia até então, no final dos anos de 1940. "Van Eyck desenhava conscientemente os equipamentos de forma mínima para estimular a imaginação de seus usuários: as crianças. O objetivo era que pudessem 
apropriar-se do espaço, deixando as interpretações em aberto" (OUDENAMPSEN, 2011).

No mesmo período, o casal de arquitetos ingleses Alison e Peter Smithson também observava a vitalidade das ruas e as relações entre pessoas e espaços. O casal extraiu "suas primeiras noções de identidade e associação" (ABRAHÃO, 2008 , p. 92) por meio do contato direto com as ruas londrinas e com o fotógrafo Nigel Henderson - cujo trabalho revelou o cotidiano da cidade inglesa - e pelo contato com o existencialismo parisiense, dominante na capital francesa (FRAMPTON, 1997, p. 330). As fotos de Henderson (Figura 02) foram expostas pelo casal no nono CIAM, em Aix-en-Provence, em 1953, e revelaram apropriações espontâneas dos espaços e relações sociais que dão forma à identidade dos lugares, como pode ser visto na capa do livro com as fotografias de Henderson.

Figura 02: Capa do livro de fotografias de Nigel Henderson.

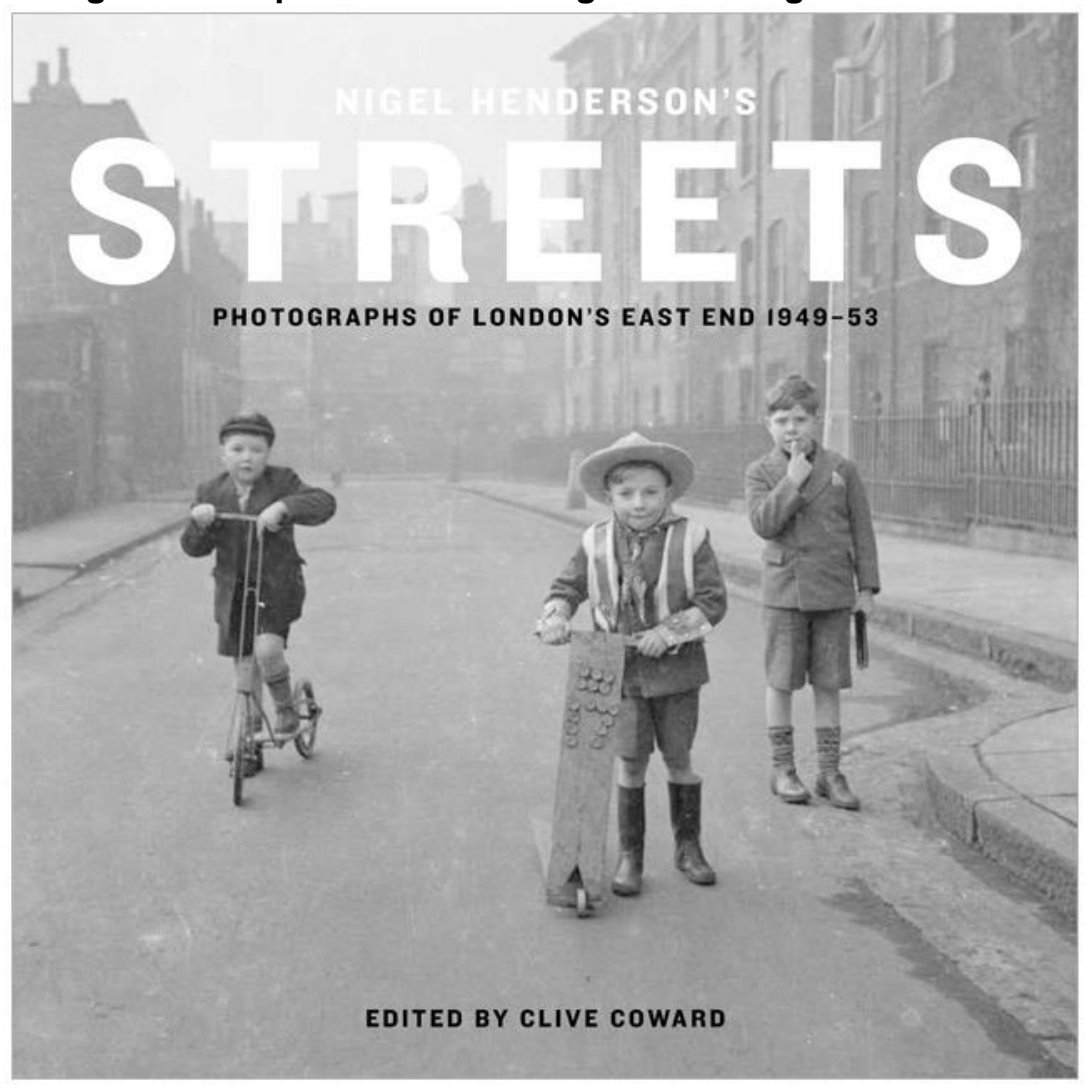

Disponível em: <http://shop.tate.org.uk/content/ebiz/shop/invt/19180/nigel-henderson-streetslondon1-19180-large.jpg> Acesso em: 17 ago 2017. 
A importância da questão do encontro entre as pessoas é comum entre os arquitetos e a arquiteta supracitados. Assim, percebe-se que a apropriação para os integrantes do Team 10 era uma questão, algo a ser colocado em pauta e estudado e que gerasse propostas projetuais mesmo que tais propostas revelassem notórias contradições com os discursos. Portanto, há limitações para as propostas arquitetônicas quanto à apropriação, talvez precisamente por ela ser encarada de forma superficial, como uma questão não desenvolvida ${ }^{47}$.

No leque das teorias relacionadas às apropriações, insere-se também os estudos de Cullen (1983) sobre a "Paisagem Urbana", título de seu livro de 1971. Nesta obra, o autor busca colocar a apropriação dos espaços como um dos critérios a serem observados nos estudos das cidades, ou no escopo de projetos de arquitetura e urbanismo. Cullen observou o comportamento das pessoas na utilização dos espaços, notando que elas não realizavam, necessariamente, as funções para as quais os espaços foram desenhados (ou as destinações esperadas para esses espaços). Para ele, além das ocupações dos espaços em seus fins designados, são formas de apropriação "A ocupação de determinados espaços ou linhas privilegiadas no exterior, os recintos, pontos focais, paisagens interiores, etc." (CULLEN, 1983, p. 23)

Na prática, o entendimento que Cullen (1983) faz da apropriação está próximo de uma adaptação e uso, restringindo-a às possibilidades de uso e fruição dos espaços. Assim, um espaço "apropriável” não necessariamente será apropriado, mas será propício para os usos e sociabilidades. Isso aconteceria na medida em que o espaço se localizar em uma área aprazível, segura, que privilegie uma visada interessante da cidade ou de um elemento natural; que

\footnotetext{
${ }^{47}$ Recentemente um dos ícones da arquitetura inglesa brutalista, projetada pelo casal Smithson, esteve no centro de uma polêmica. O conjunto Robin Hood Gardens teve sua demolição aprovada depois de anos de embates entre a narrativa governamental sobre a visível deterioração dos edifícios em contraponto à narrativa de grandes nomes da arquitetura (Zaha Hadid, Richard Rogers, Robert Venturi, entre outros) sobre a função histórica e social dos edifícios. Deste embate, nem a história da arquitetura e nem a função social da habitação saíram vitoriosos, visto que o conjunto dará lugar a uma sequência de torres para novos apartamentos que, como salientado pelas críticas, não serão baratos e não resolverão os problemas ignorados pelo casal Smithson, como a desconexão com a malha urbana imposta pelas vias de acesso que cercam o conjunto.

Visto em: < https://www.theguardian.com/artanddesign/2010/dec/05/robin-hood-gardens-eastlondon $>\mathrm{e}<\mathrm{https}$ ://www.archdaily.com.br/br/878712/robin-hood-gardens-de-alison-e-petersmithson-comeca-a-ser-demolido > Acesso em: 20 set. 2017.
} 
permita o descanso, o lazer, a contemplação e o encontro; que instigue a descoberta de novas rotas e elementos arquitetônicos, e etc.

Tanto para Cullen (1983) quanto para os arquitetos do Team 10, as apropriações pouco foram entendidas em seu potencial prospectivo, mas, sim, como forma de manter ou reforçar aspectos culturais e laços já estabelecidos. $O$ Team X não soube aplicar as questões das apropriações e do pertencimento aos seus projetos, perpetuando a compreensão verticalmente determinista da arquitetura e urbanismo sobre a sociedade. Cullen, por sua vez, também não se dedicou à questão das apropriações de forma a compreendê-las em profundidade.

Nesse sentido, observamos também no período pós 2a Guerra Mundial, uma das principais obras contestadoras do urbanismo modernista funcionalista, o "Morte e Vida das Grandes Cidades" (1961), da jornalista Jane Jacobs. A jornalista observou o gradual esvaziamento dos espaços urbanos à medida em que o urbanismo por ela chamado "ortodoxo" era introduzido na cidade de Nova lorque, destruindo e reformulando não somente os espaços, mas a vida urbana e as relações sociais estabelecidas.

Jacobs desenvolveu a ideia de que o desenho das ruas, calçadas e praças e a construção histórica das relações de vizinhança poderiam favorecer a vitalidade urbana, com a continuidade da cultura urbana por meio do reconhecimento de seus espaços como parte do cotidiano local. Assim, as formas e as possibilidades proporcionadas pelo desenho e distribuição dos espaços podem preservar a cultura, a diversidade arquitetônica, a vida e vitalidade das cidades através dos usos cotidianos dos espaços. A autora não trata especificamente de apropriação, mas aponta tanto para o rompimento do pertencimento e da cultura urbanas impulsionado pelo urbanismo e planejamento urbano, quanto para as formas de construção coletiva da sociedade nos espaços urbanos consolidados.

Percebemos que há um esforço intelectual, teórico e prático de compreensão e resolução dos evidentes problemas advindos da aplicação das ideias do modernismo funcionalista. As críticas, contudo, não atacaram 
diretamente o modo de produção capitalista do espaço que, como constatou Lefebvre, cria e recria constantemente contradições urbanas ${ }^{48}$. As críticas mais incisivas realizadas ao urbanismo funcionalista ou ao urbanismo em si foram realizadas por grupos e intelectuais de inspiração marxista e anarquista, pois compreenderam o papel do sistema econômico vigente na produção de espaços e sociedade cada vez mais distanciadas (ou alienadas) dos rumos que se desenham para eles.

\title{
3.2. O cotidiano, a apropriação do espaço e o direito à cidade: uma abordagem lefebvriana
}

\subsubsection{Dos Situacionistas a Lefebvre: crítica do cotidiano urbano}

As relações entre pessoas e seus espaços (pensados aqui de modo amplo) têm despertado o interesse de artistas, filósofos e outros estudiosos desde muito tempo. Há, contudo, uma mudança radical dessas relações no período pós Revolução Industrial, com a ascensão das cidades e Estados "modernos" no século XIX. Da cidade política à cidade comercial e, dela, à cidade industrial (LEFEBVRE, 1999).

\begin{abstract}
Nesse movimento, a realidade urbana, ao mesmo tempo amplificada e estilhaçada, perde os traços que a época anterior Ihe atribuía: totalidade orgânica, sentido de pertencer, imagem enaltecedora, espaço demarcado e dominado pelos esplendores monumentais (LEFEBVRE, 1999, p. 23).
\end{abstract}

Das referências mais conhecidas sobre espaço urbano, principalmente 0 espaço público, e sua dimensão social temos como exemplos os estudos de Richard Sennett (1988) sobre a perda do sentido e dos espaços para a realização do homem público; de Hannah Arendt (2010) sobre as alterações nos sentidos do espaço público e sua centralidade na configuração de uma sociedade e; no campo das artes, ficaram famosas as poesias de Baudelaire $(1985)^{49}$ repletas de metáforas sobre a moderna Paris no século XIX e os efeitos

\footnotetext{
${ }^{48}$ Cabe ressaltar que Lefebvre não critica apenas a produção do espaço em Estados capitalistas, mas também nos socialistas, acusando-os principalmente de não romperem com a lógica hierarquizada de intervir nas cidades.

${ }^{49}$ BAUDELAIRE, Charles. O cisne. In: As Flores do Mal. Rio de Janeiro: Nova Fronteira, 1985.
} 
emocionais causados pelas mudanças dos espaços e ritmo de vida. Destaca-se a referência do poeta às obras haussmannianas que remodelaram Paris, reconfigurando relações de identidade. O poema "O Cisne" 50 retrata a melancolia da modernidade urbana parisiense:

Fecundou-me de súbito

a fértil memória,

Quando eu cruzava a passo o novo Carrossel

Foi-se a velha Paris (de uma cidade a história

Depressa muda mais que um coração infiel)

(...)

Paris mudou! Porem minha melancolia

é sempre igual: torreões, andaimarias, blocos,

Arrabaldes, em tudo eu vejo alegoria,

Minhas lembranças são mais pesadas que socos.

Com a alteração dos modos de produção e apropriação das cidades, mudam-se seus ritmos, símbolos e sociabilidades. A cidade histórica, palco de trocas e local privilegiado do público, perde lugar para a produção capitalista do espaço, com o protagonismo das fábricas e circulação de produtos e trabalhadores. Mesmo que num primeiro momento estivessem distantes da cidade e próximas das fontes de energia e das matérias-primas, as fábricas se aproximam gradativamente das cidades (e dos capitais, capitalistas e da profusa mão-de-obra barata), penetrando-a e a fazendo explodir (LEFEBVRE, 1999, p. 23). O processo de produção capitalista (indústria, trabalho, tempo e espaços) foi determinante, portanto, para o que conhecemos como o urbano atual.

Menciono as alterações sociais, econômicas e políticas (indissociáveis no entendimento do urbano), pois, segundo a interpretação de Lefebvre aqui utilizada, as dinâmicas provocadas pela industrialização das cidades culminam no que o autor considera a "fase crítica" para o urbano, além de constituir um período essencial no entendimento da produção e forma urbanas atuais. Há, claramente, um encadeamento entre a indústria (a industrialização e o pensamento industrial) e o "fenômeno urbano", tanto em forma quanto em conteúdo. A industrialização provoca alterações rápidas na dinâmica urbana que, por sua vez, altera-se e passa a ser a principal "indutora" de mudanças em

50 Idem, p. 326-327. 
escala mundial, ou seja, "o induzido torna-se dominante (indutor)" (LEFEBVRE, 1999, p. 24).

Cabe ressaltar que, mesmo sendo o foco de grande parte dos pesquisadores da arquitetura, urbanismo e sociedade modernos, as críticas às cidades não se restringiram apenas aos espaços projetados pelos modernistas, mas incidiram também sobre toda a sociedade moderna e mesmo em espaços urbanos historicamente consolidados. Isto porque a cultura e os tempos das cidades foram alterados, resultando em um cotidiano urbano cada vez mais voltado à produção capitalista e, por isso, com o seu valor de troca sobressaindo ao valor de $u^{51}$.

Nesse sentido, a arquitetura e urbanismo de corrente corbusiana, caracterizada pelo funcionalismo, foram instrumentos que colaboraram com a ampliação das diferenças sociais e espaciais e para a manutenção de uma sociedade alienada, pois organizada para a realização de funções determinadas, limitantes e politicamente esvaziadas, e localizando as pessoas distantes dos centros de decisão. A partir de uma leitura marxiasta e lefebvriana, podemos afirmar que o modernismo funcionalista via a população como a simples soma dos indivíduos, desprezando a historicidade e a coletividade que formam as classes; os sujeitos políticos e históricos.

A racionalidade funcionalista do modernismo contribuiu, consequentemente, para o esvaziamento das relações de pertencimento, de identidade e das possibilidades de fruição ou usos que não estivessem prédeterminados, ou seja, dos sentidos subjetivos presentes no cotidiano do urbano e das possibilidades de produção coletiva dos espaços. As críticas mais incisivas observaram, então, que a sociedade moderna, nos meados do século XX, aceitou com certa passividade a imposição de um cotidiano meramente operativo e no qual a cultura do consumo teve papel determinante nesta

\footnotetext{
51 Dessa forma, como veremos adiante, mesmo em se tratando de contextos históricos diferentes, as análises do cotidiano urbano de Lefebvre constituem-se como arcabouço teóricometodológico capaz de analisar e explicar o processo de alienação do espaço que acontece em Viçosa e, mais especificamente, nos conjuntos do Programa Minha Casa, Minha Vida estudados no presente trabalho.
} 
passividade. Cabe ressaltar que é de 1947 o livro de Theodor Adorno e Max Horkheimer intitulado "Dialética do Esclarecimento", no qual cunham o termo "indústria cultural” e apontam, no contexto histórico da época, para o uso de seus produtos na manutenção de uma sociedade excludente e alienada (ZUIN, 2001).

Observando essa espécie de controle a partir da cultura de massa sobre a sociedade, emerge o grupo chamado de Situacionista (1957-1972) composto por intelectuais e artistas (de inspirações dadaístas e surrealistas) que teciam críticas aos caminhos tomados pela arte contemporânea e que passaram e direcionar seus trabalhos para os problemas da sociedade urbana (LIMA, 2014; MONTE, 2015).

Tendo como um dos principais expoentes Guy Debord, autor do livro "A Sociedade do Espetáculo" (1967), os Situacionistas denunciaram a alienação social à qual estamos submetidos como resultado do modo de produção e organização social capitalistas, resignificados com o crescimento da indústria da cultura de massas, contribuindo diretamente no processo de reificação ${ }^{52}$ do cotidiano (MONTE, 2015). Segundo Debord (apud MONTE, 2015, p. 22) "o espetáculo na sociedade corresponde a uma fabricação concreta da alienação"

Os Situacionistas, portanto, tinham como foco o cotidiano da vida urbana, entendendo-a como uma espécie de gatilho no qual práticas revolucionárias poderiam disparar a compreensão e, posteriormente, a superação da sociedade capitalista de classes. Para tanto desenvolveram - com inspirações surrealistas e no flâneur descrito por Walter Benjamin sobre Baudelaire - teorias e práticas urbanas de modo a acessar a subjetividade escamoteada nas cidades fragmentadas. Como pode ser visto na mensagem escrita durante o Maio de $68^{53}$, pela perspectiva situacionista, "Aquele que fala da revolução sem querer

\footnotetext{
${ }^{52}$ Conceito marxiano que descreve o resultado do processo no qual a subjetividade humana e as relações sócias apresentam características de objetos inanimados (sem autonomia ou autoconsciência), submetida que estão aos modos de produção capitalista. Ao processo de dotar de características humanas às coisas também se chama reificação. "(...) as relações sociais entre seus trabalhos privados aparecem como aquilo que elas são, isto é, não como relações diretamente sociais entre pessoas em seus próprios trabalhos, mas como relações reificadas entre pessoas e relações sociais entre coisas" (MARX, Karl. O caráter fetichista da mercadoria e seu segredo. In: O Capital livro I. São Paulo: Boitempo Editorial, 2017. p. 148)

${ }^{53} \mathrm{Um}$ conjunto de protestos e greves realizadas na França no mês de maio de 1968 que chegou a mobilizar 10 milhões pessoas entre estudantes e trabalhadores. Contaram com a participação de diversos grupos organizados, como anarquistas, marxistas e os situacionistas.
} 
mudar a vida cotidiana tem na boca um cadáver"54 (Figura 03). Nas palavras de Lefebvre (apud NETTO, 2012, p. 50): "Seja o que vier, a mudança no cotidiano permanecerá o critério da mudança". Ou seja, nenhuma revolução se dará se não passar por mudanças revolucionárias no cotidiano, sendo esta a base sobre a qual a mudança acontecerá, seja ela qual for.

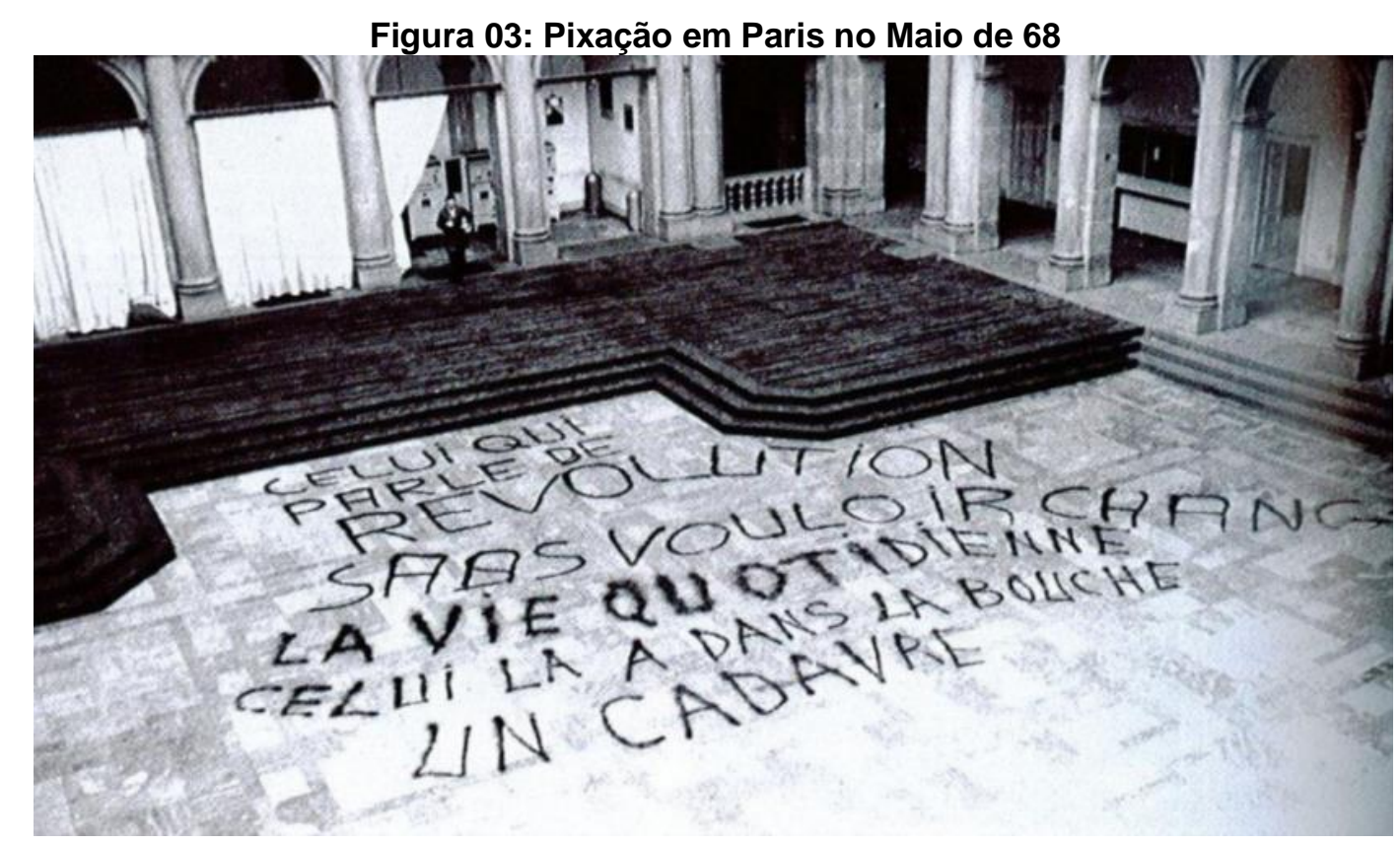

Disponível em: <https://inventin.lautre.net/graffiti.html> Acesso em: 19 ago 2017.

As cidades são, para os Situacionistas, a expressão dessa cultura industrializada que aliena as pessoas da luta de classes em um processo no qual o hábito operatório substitui as práticas cotidianas livres. O funcionalismo imposto pelas grandes reformas urbanas - com construções de novos bairros e cidades - reforçaram o controle e a hierarquização da sociedade. Segundo Jacques (apud MONTE, 2015, p.19), "enquanto os modernos acreditaram, num determinado momento, que a arquitetura e o urbanismo poderiam mudar a sociedade, os situacionistas estavam convictos de que a própria sociedade deveria mudar a arquitetura e o urbanismo".

54 Frase de provável inspiração em Raoul Vaneigem, um dos principais nomes entre os Situacionistas. Frase original traduzida: "Aqueles que falam de revolução e de luta de classes sem se referir à vida cotidiana, sem compreender aquilo que há de subversivo no amor, de positivo na recusa do constrangimento, estes carregam na boca um cadáver" Disponível em: <https://razaoinadequada.com/2014/11/10/vida-cotidiana/> Acesso em: 19 ago 2017. 
A forma de combater a excessiva racionalidade modernista seria, então, promover e resgatar a subjetividade cotidiana.

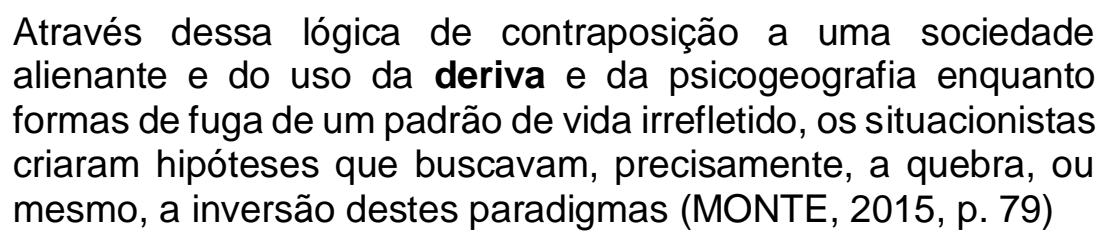

As teorias situacionistas são fonte e campo de debates para Lefebvre, que vem a construir também no cotidiano urbano o centro de um conjunto de ações que podem (devem) levar à chamada Revolução Urbana, título de sua obra mais conhecida. Em entrevista a Kristen Ross ${ }^{55}$, em 1983, Lefebvre revela que Debord eram próximos e dividiam questões teórica e práticas, corroborando com autores que apontam para a mútua influência entre os surrealistas, os situacionistas e Lefebvre no objetivo de entender a cidade e o cotidiano urbano (LIMA, 2014; VELLOSO, 2016; HARVEY, 2014, p. 12; GUTIÉRREZ, 2013, p. 34). Posteriormente, contudo, por discordâncias entre Lefebvre e Debord, há o rompimento da relação entre Lefebvre e os Situacionistas.

A prática da Deriva pode ser caracterizada como um tipo de errância observadora nos espaços urbanos e, segundo o que Lefebvre apontou para Ross, a Deriva teve grande importância pois "revelou a fragmentação crescente da cidade". Dessa forma, por meio da prática da Deriva situacionista, pode-se observar as rupturas entre a cidade histórica e a cidade industrial e também a fragmentação do tecido urbano e social, com as distinções intraurbanas cada vez mais manifestas, como afirma Lefebvre sobre a década de 1960 em Paris ${ }^{56}$.

Há, neste ponto, a convergência de entendimentos entre Lefebvre, Debord e Vaneigem no que diz respeito à fragmentação dos saberes, das práticas e do tecido urbano e social (VELLOSO, 2016). Lefebvre, então, defende a construção de uma ciência capaz de buscar a totalidade do fenômeno urbano e, com isso, combater a fragmentação e a ideologia urbanas resultantes da

\footnotetext{
55 Tradução disponível em: <https://politicadasensibilidade.wordpress.com/2015/02/26/henrilefebvre-e-a-internacional-situacionista/> Acesso em: 19 ago 2017.

56 Op. cit.
} 
parcialidade dos campos de atuação de arquitetos, urbanistas e outros profissionais que buscam ler e intervir no espaço urbano.

Com a rápida urbanização da França e o crescimento desmesurado de sua capital, rompendo laços históricos e direcionando-se à constituição de espaços alienados, Lefebvre se distancia dos Situacionistas e aprofunda seus estudos não apenas na crítica às cidades e organização econômica-social burguesa, mas na procura de um entendimento sobre o fenômeno urbano e suas possibilidades ${ }^{57}$.

Entendemos, portanto, que Lefebvre deu profundidade teórica e metodológica às questões colocadas pelo pensamento utópico situacionista, avançando em direção tanto no entendimento da produção do espaço e da sociedade alienados como para as possibilidades de superação dos mesmos. Superou, portanto, a visão pessimista do criticismo à cultura e arte modernas, indicando as contradições presentes no cotidiano tanto como sinais da alienação urbana da sociedade, quanto como contentoras das possibilidades de emancipação social (GUTIÉRREZ, 2013, p. 41). Para Lefebvre, a revolução urbana está nas resistências anticapitalistas e coletivas de usos dos espaços, como "forma política da práxis" (VELLOSO, 2016).

Dessa forma, devemos frisar que a compreensão lefebvriana das apropriações e do direito à cidade têm intrinsecamente um horizonte utópico de realização plena do trabalho e do ser na história. O Direito à Cidade se concretizaria, então, quando o poder de decisão sobre os bens coletivos estiver nas mãos do próprio coletivo, o que aproxima Lefebvre novamente das compreensões marxianas. Partimos do entendimento, então, de que os processos "gêmeos" de apropriação e de desalienação dos espaços urbanos são rupturas nos modos de produção alienados e segregadores. É tal a centralidade do espaço urbano na realização ou não das possibilidades humanas de cidadania e emancipação que esses processos, mesmo quando não levados ao horizonte revolucionário proposto por Lefebvre, constituem-se como mostras da

\footnotetext{
57 Lefebvre ataca apenas o trabalho alienado e defende a cidade como obra, resultado dos trabalhos e apropriações livres e coletivos, os Situacionistas chegam a defender o fim de qualquer espécie de trabalho, colocando apenas a arte como forma superior de trabalho e que, mesmo assim, não deveria ser especializada, mas realizada por todos.
} 
tomada dos espaços pelo coletivo que, no caso dos moradores do MCMV, fazem parte da classe trabalhadora espoliada das possibilidades de realização de sua cidadania.

3.2.2. Crítica lefebvriana: o cotidiano alienado e a produção funcionalista do espaço urbano

Em algumas das obras de Lefebvre $(1962 ; 1964 ; 1971 ; 1999 ; 2001 ; 2013)$ fica claro a disparidade de pensamentos e o descontentamento do francês em relação ao entendimento hegemônico na arquitetura e urbanismos sobre a moradia e a cidade. Para o francês, o pensamento de Le Corbusier e "sua escola" propõem um positivismo sociológico "que ocasionam mais problemas do que os resolvem" (LEFEBVRE, 1971, p. 151, tradução nossa).

As críticas lefebvrianas ao cotidiano e ao urbano partem de sua observação do contexto francês de industrialização e urbanização acelerados no período pós Segunda Guerra Mundial. Era o início dos chamados "trinta gloriosos" 58 , quando Lefebvre publica seu livro "Crítica da vida cotidiana"59, em 1947. Em sua crítica ao cotidiano, Lefebvre aponta para como a divisão do trabalho e a lógica industrial (funcionalista e fragmentária) estão presentes na vida das pessoas nas cidades, modificando as relações sociais. $O$ autor questiona até mesmo qual seria a consciência de uma vida que é quase alienada $^{60}$ e reificada (NETTO, 2012, p. 39; LEFEBVRE, 1964; 1971, p. 101)

Neste contexto Lefebvre observa a ascensão das ideias e práticas de um urbanismo moderno "operatório" (LEFEBVRE, 1999), que materializa a divisão técnica e social do trabalho no campo das cidades, segregando funções e populações e alienando as pessoas da produção dos espaços, colocando-os sob a afirmação do valor de troca característico da sociedade capitalista. Lefebvre,

\footnotetext{
58 Período referente às três décadas (1945 a 1975) de prosperidade sobretudo de países europeus - como França, Inglaterra e Itália -, quando passaram por grandes transformações espaciais, produtivas, sociais e econômicas. Parte deles com inspiração da política econômica keynesiana.

59 O primeiro de três livros do autor com o mesmo título $(1947 ; 1961 ; 1981)$.

${ }^{60}$ Para Lefebvre (1971, p. 101, tradução minha): "Toda atividade viva e consciente que se perde, se extravia, se deixa arrancar de si mesma, e por conseguinte se separa de sua plenitude, está alienada"
} 
portanto, não tem apenas fontes teóricas para seus questionamentos (sobre as quais escreveu durante toda a carreira), mas, além de seu conhecimento da dialética hegeliana e marxista e dos estudos de Heidegger e Nietzsche (GUTIÉRREZ, 2013, p. 40; SCHMID, 2012, p. 90), teve como base estudos empíricos realizados, sobretudo na década de 1960, tanto no meio rural francês ${ }^{61}$ (quando observou a extensão do urbano sobre o rural) como em novos conjuntos habitacionais e cidades operárias ${ }^{62}$, construídas na França industrial a partir do ideário modernista.

Este modelo de arquitetura e urbanismo proporcionou o arcabouço teórico para a realização de reformas urbanas, construção de conjuntos habitacionais (grands ensembles), de bairros e até de cidades inteiras (villes nouvelles) onde prevalece a compreensão de hierarquização da sociedade, fragmentação e especialização espaciais, e de funcionalismo determinista da vida, conjugados e engessados - nas quatro funções primordiais urbanas colocadas na Carta de Atenas. Segundo Netto (2012, p. 45), Lefebvre aponta para a transformação lenta, mas profunda do cotidiano a partir da transformação do espaço. "O problema do novo urbanismo, filosoficamente colocado, consiste em criar intencional e racionalmente (...) uma vida social igual ou superior à vida nascida da história" (LEFEBVRE, 1971, p. 174).

Lefebvre sugere que as cidades historicamente construídas e consolidadas tinham unicidade, como se seus elementos compusessem uma unidade na qual há mudanças espaciais suaves, obedecendo ao ritmo e à história de cada casa, rua, praça, etc. Segundo Lefebvre (1962, tradução minha) sobre uma pequena cidade tradicional francesa, "Embora existam em Navarrenx esboços de diferentes bairros (em torno da feira, da igreja e da prefeitura e fora das muralhas, nos subúrbios), nenhum desses bairros se separa dos outros".

Já os novos espaços (conjuntos habitacionais, bairros e cidades) são planejados a partir da lógica fabril para resultarem na forma de menor custo de vida (LEFEBVRE, 1971, p. 184); com o intuito de ordenar a vida antes mesmo

${ }^{61}$ Cf. LEFEBVRE, 1971; LEFEBVRE, Henri. La vallée de Campan - Étude de sociologie rurale. Paris, 1963

62 Cf. LEFEBVRE, 1964 
que ela os habite. Dos estudos empíricos de Lefebvre, destacam-se os realizados em Aix-en-Provence e em Lacq-Mourenx. Nestas cidades, o autor observou nos espaços construídos do zero um vazio de significados, de símbolos; têm no aborrecimento e no tédio seus sintomas de mal-estar mais aparentes (LEFEBVRE, 1964; 1971). No primeiro caso, em Aix-em-Provence, há a construção de bairros novos voltados a determinadas classes sociais e anexados a uma antiga cidade. O segundo, Mourenx, uma pequena cidade modernista construída do zero para abrigar funcionários do complexo industrial construído em Lacq, nas proximidades de Mourenx (Figura 04).

Figura 04: Vista de Mourenx e o complexo industrial de Lacq

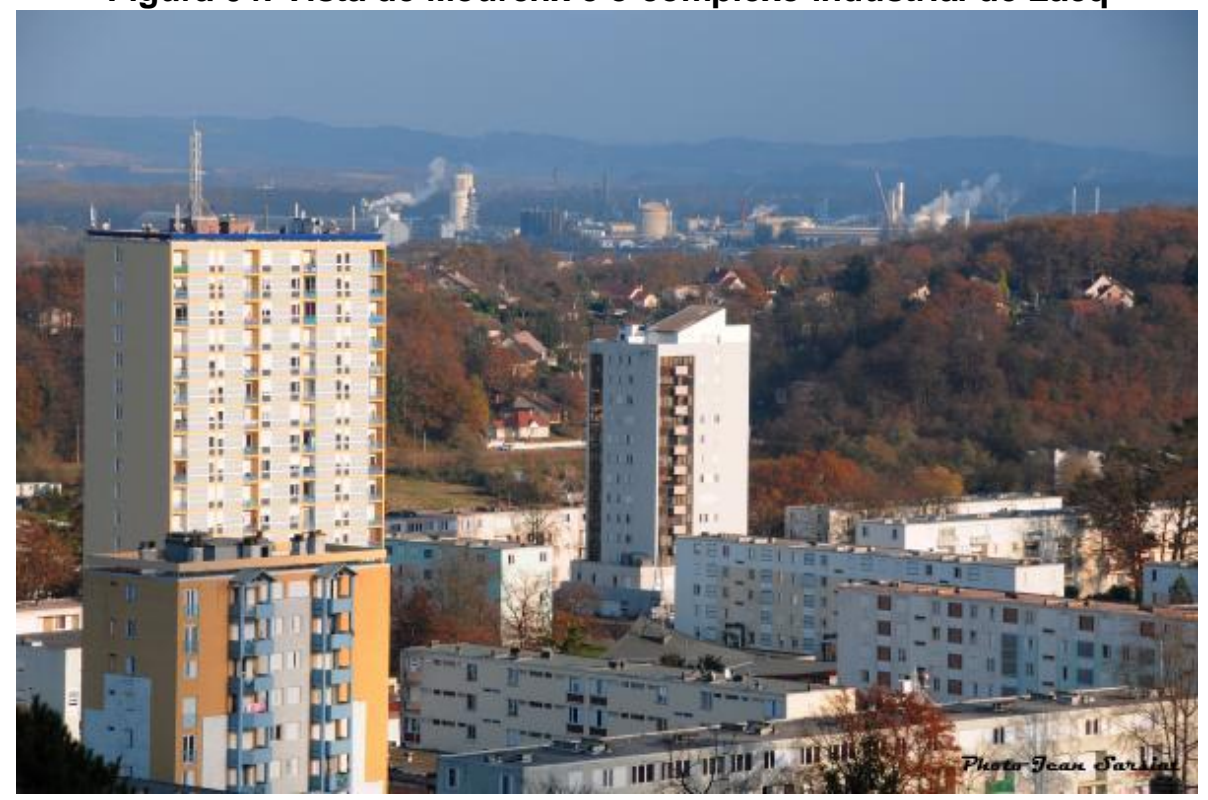

Em primeiro plano, Mourenx. Em segundo, fábricas de Lacq. Foto sem data e autor. Disponível em: <http://www.paysdesgaves.com/tag/mourenx-pays\%20de\%20lacq/> Acesso em: 02 out 2017.

O plano de massas de Mourenx foi inteiramente concebido entre o Estado e o arquiteto responsável, René Coulon. A implantação não desarmoniza com o entorno de colinas e vinhedos e as edificações são bem projetadas e construídas $^{63}$ (LEFEBVRE, 1962). A cidade tem seus edifícios compondo um ritmo de planos horizontais e torres verticais (Figura 05); uma variedade arquitetônica para combater a monotonia (LEFEBVRE, 1964, p. 8). Assim, busca-se evitar improficuamente, como em outros projetos modernistas, 0

${ }^{63}$ Apesar das queixas relatadas por Lefebvre (1964, p. 10 e 11) sobre a falta de isolamento acústico das unidades habitacionais. 
aborrecimento por meio de uma variedade simplesmente "plástica" (LEFEBVRE, 1971, p. 129).

Figura 05: Mourenx e o complexo industrial de Lacq

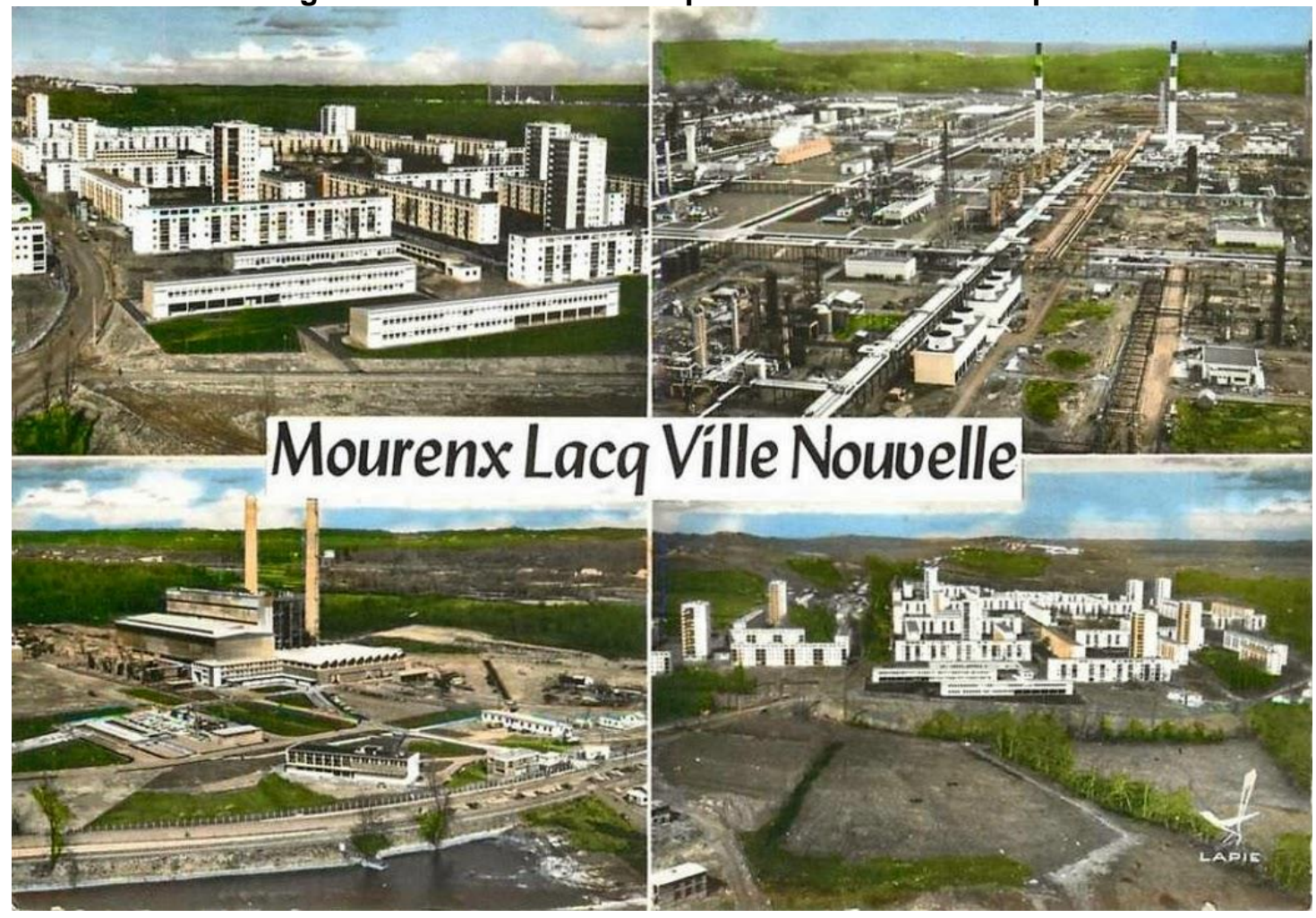

Montagem de um cartão postal

Disponível em: <http://2.bp.blogspot.com/-

iMRInEuG2p0/Um1fC3Kp4wl/AAAAAAAAEtt/wK39YyeFBlo/s1600/mourenx-carte-postale23.jpg>

Acesso em: 02 out 2017.

A velocidade da sociedade moderna, somada à violência da prática impositiva modernista da arquitetura e do urbanismo, contribuem para que os espaços resultantes imponham à vida os ritmos "lineares e descontínuos exigidos pela técnica" (LEFEBVRE, 1971, p. 131, tradução minha) que aumentam a sensação de perda de referências.

Sobre a questão simbólica e identitária, Lefebvre (1964, p. 9-12) observou em Mourenx um problema curioso que exemplifica a desconexão com o passado - inexistente - da cidade: à ela faltava um cemitério e mortos. Na ocasião, os representantes políticos locais planejavam uma cerimônia acompanhada de um baile, o que poderia "cimentar a comunidade recentemente estabelecida" (LEFEBVRE, 1964, p. 9). Contudo, à cidade nova falta história e a cerimônia teve seu local alterado para a "cidade velha" mais próxima. A mesma, observa 
Lefebvre, à qual a cidade nova "está desintegrando e negando pelo simples fato de sua existência" (LEFEBVRE, 1964, p. 10) Na sociedade moderna, com seus novos conjuntos e cidades, como afirma Netto (2012, p. 38): "(..) parece que nada de antigo se mantém e nada de novo chega a criar raízes"

Sentir falta de símbolos e monumentos é apenas a aparência de uma cidade tediosa. Como tudo é "funcional", não há espaços para a surpresa exigida pela vida (LEFEBVRE, 1971). Todos os signos são inteiramente legíveis e, por isso, desinteressantes. Lefebvre (1964) observa que depoimentos de moradores sentindo falta de um cemitério é sintomático da ausência de elementos "suprafuncionais", contentores de possibilidades para além dos caminhos prédeterminados pelo cotidiano da produção capitalista e funcionalismo espacial. "A função do cemitério é abrigar defuntos. Mas ele possui para os membros do grupo (...) um valor simbólico. Ele exprime a continuidade, as ligações com o passado, com o tempo e com o espaço" (LEFEBVRE, 1964, p. 12)

Sob a égide da divisão social e técnica do trabalho, ao urbanismo funcionalista "escapam algumas das mais importantes funções, em particular a animação completa da vida, as condições de uma certa felicidade, a luta conta a monotonia e o aborrecimento" (LEFEBVRE, 1971, p. 137, tradução minha). O lúdico, que é função essencial da cidade (LEFEBVRE, 1971, p. 144), é apartado das ruas e calçadas (algo observado também por Jacobs e, em certa medida, pelo Team X) e posto em espaços próprios.

Reitera-se, assim, o esvaziamento da rua no que a dota de sentido para além da mera circulação (LEFEBVRE, 1971, p. 182). Em um exercício de crítica ${ }^{64}$ à rua na sociedade de consumo dirigido, Lefebvre (1999, p. 28-29) aponta que:

A rua regula o tempo além do tempo de trabalho: ela o submete ao mesmo sistema, o do rendimento e do lucro. Ela não é mais que a transição obrigatória entre o trabalho forçado, os lazeres programados e a habitação como lugar de consumo.

Segundo Lefebvre, os novos conjuntos de arquitetura e urbanismo corbusiano suprimiram a rua e tiveram como consequência a "redução da cidade

\footnotetext{
${ }^{64}$ Ressalta-se que Lefebvre, nesse ponto de seu trabalho, está ponderando pontos a favor e contra a rua. Contudo, a compreensão sobre a rua para Lefebvre vai além da crítica, conseguindo também vislumbrar seu potencial de encontro e de apropriação coletiva.
} 
a dormitório" em uma "aberrante funcionalização da existência" (1999, p. 27). Assim, as possibilidades de realização da vida social espontânea por meio do cotidiano e do jogo diminuem, pressionando as pessoas ao recolhimento para a esfera privada. Soma-se a isso um quadro de evidente segregação social e fragmentação espacial, além das perdas dos laços de sociabilidade anteriormente estabelecidos pelas famílias moradoras desses novos conjuntos e cidades ${ }^{65}$. Nas palavras de Adorno e Horkheimer, a compreensão funcionalista destina-se "a perpetuar o indivíduo como se ele fosse independente"66, isolandoo de seu contexto urbano e social. Resulta, pois, no "extremo de uma tendência geral”, qual seja, a privatividade da vida que, como ressalta Lefebvre (1964, p. 10-11), não é acompanhada de privacidade nesses novos conjuntos. Ainda segundo o autor, então, "se converte em vida privada no sentido mais duro da expressão, ou seja, privação e frustação toleradas graças a uma espécie de embotamento do ser social humano" (LEFEBVRE, 1971, p. 180)

A inserção social caracteriza-se, segundo Lefebvre (1962), como mera e forçada adaptação. A vida, afinal, deve acontecer e "Não se adaptar é sofrer de um sofrimento obscuro e constante" (LEFEBVRE, 1962, tradução minha) Contudo, compreende-se que as pessoas têm necessidade de se apropriarem de espaços pela necessidade de socialização, pois através da exposição do indivíduo para o grupo é que ele se faz sujeito. Só existe na sociedade aquele que foi visto e ouvido por ela (ARENDT, 2010). Lefebvre relata sobre a rua como local de confirmação do eu perante o outro, da passagem da vida privada à vida social: "Ando contente ou descontente, preocupado ou relaxado, desgostoso ou distraído, e minha situação se revela mais claramente, para mim mesmo, desde o momento em que saio do escritório, da fábrica ou da minha casa. Estou de novo disponível (...)" (LEFEBVRE, 1971, p. 95)

Cabe-nos destacar que, para Lefebvre (2013, p. 323), não basta estritamente ser visto e ouvido, pois esses sentidos podem, em determinados

\footnotetext{
${ }^{65}$ Como relatado anteriormente neste trabalho sobre as new towns blues.

66 HORKHEIMER, Max; ADORNO, Theodor W. A indústria cultural: o esclarecimento como mistificação das massas. Dialética do esclarecimento, p. 113-156, 1985.
} 
casos, afirmar o fetiche ${ }^{67}$ do espaço pela mera imagem que apresenta: "O predomínio do visível ocasiona um conjunto de substituições e deslocamentos mediante os quais o visual suplanta e supre ao corpo inteiro". Para Lefebvre, então, a fragmentação do urbano tem ainda outra consequência que seria a perda do espaço sensorial, do "não-visual" (2013, p. 395), das possibilidades de realização corporal completa, sensível.

Não é menos verdadeiro que o urbano se define como lugar onde as diferenças são conhecidas e, ao serem reconhecidas, postas à prova. Portanto, confirmando-se ou anulando-se. Os ataques contra o urbano consideram, fria e alegremente, 0 desaparecimento das diferenças, não raro identificadas ou confundidas com as particularidades folclóricas. A ideologia industrial, tecnocrática ou individualista, é homogeneizante (LEFEBVRE, 1999, p. 90)

A funcionalização dos espaços leva ainda a um empobrecimento do texto social, configurando-se em uma das maiores contradições das cidades: 0 urbano, sinônimo de reunião e concentração, ao mesmo tempo em que reúne, separa. Ademais, "Tudo o que era separável foi distinguido e separado: não apenas os domínios e os gestos, mas os lugares e as pessoas" (LEFEBVRE, 1962, tradução minha).

A cidade inteiramente planejada de cima para baixo pelo Estado e seus técnicos de saberes parcelares mostra-se maçante. As possibilidades do/no cotidiano dificilmente propiciarão o trabalho enquanto força criativa que anima os humanos. Assim, a cidade como obra ${ }^{68}$ - objeto e objetivo orgânico coletivo - fica mais distante de se concretizar a partir de seus espaços. Reafirma-se a fragmentação, a alienação, a segregação e o individualismo.

Tudo se separa e, no entanto, totaliza. Tudo é reificado e ainda se move. O perigo triunfa. Paradoxos. Somos colocados na frente de um "mundo" em peças sobressalentes, quebradas em mil "mundos" pequenos. Ao mesmo tempo, essa deslocação -

${ }^{67}$ Fetiche é um conceito marxiano para explicar o domínio da imagem projetada socialmente para um objeto sobre o valor concreto dele mesmo. A aparência se sobrepõe à essência. Dessa forma há uma mistificação do objeto, que passa a ter o valor de sua imagem, projetando-se sobre as ações humanas.

68 Gutiérrez (2013, p. 42, tradução e grifo meus) na introdução para o livro "La producción del espacio" de Henri Lefebvre explica: "O termo obra não designa no pensamento lefebvrianomarxista um objeto de arte, mas se concebe como a atividade de um grupo que se apodera e assume o controle de seu papel e destino social; uma autogestão, em definitivo" 
que atinge os próprios fundamentos da prática, aos próprios fundamentos da consciência, às próprias raízes da atividade - é acompanhada por uma integração cada vez mais vigorosa (LEFEBVRE, 1962, tradução minha)

Contudo, como afirma o próprio Lefebvre (2001, p. 79): "Mesmo o cotidiano mais irrisório retém um vestígio de grandeza e de poesia espontânea (...)". Dessa forma, Lefebvre aponta para as formas de superação da alienação do espaço e da sociedade e, ainda vislumbra as possibilidades já latentes no presente da produção do urbano, espaço e texto social, que sejam reflexos diretos das apropriações, aspirações e trabalhos coletivos e autogestionados. A cidade, assim, seria como obra, figura do total desalienado, sem dominantes e dominados e passo final para a superação da sociedade de classes por meio da revolução urbana:

Ainda pode-se ir mais longe. Procurar imaginar uma cidade onde a vida cotidiana estaria completamente transformada, onde os homens seriam donos de sua vida cotidiana, que a transformariam em sua aspiração, seriam livres no sentido da cotidianidade, a dominariam completamente (LEFEBVRE, 1971, p. 145, tradução minha).

\subsubsection{A apropriação do espaço como noção lefebvriana}

Considera-se que Lefebvre, portanto, baseia sua teoria crítica e propositiva em dois problemas centrais: o cotidiano alienado e a produção ideologicamente funcionalista do espaço urbano. Estes problemas se alimentam mutuamente ou, mais precisamente, alimentam um urbano no qual o conflito é neutralizado pela passividade da cotidianidade e pela separação dos tempos, espaços e pessoas.

Assim como os problemas se alimentam, Lefebvre aponta para inversões práticas na vida cotidiana com potencial de alimentar uma prática urbana revolucionária que proporcionaria, ao contrário da alienação, um urbano como resultado do trabalho (não-alienado) coletivo emancipado (GUTIÉRREZ, 2013, P. 45). Dessa forma as cidades não seriam mais objeto de monopólios, especulações e apropriações individuais do mais-valor coletivo, mas seriam produzidas e reproduzidas obedecendo aos tempos, desejos e necessidades do corpo e das pessoas. 
Como vimos, o urbanismo funcionalista tem como centralidade ideológica a proposição do habitat, célula elementar de um organismo urbano organizado a partir da separação em funções ditas essenciais para se viver na cidade: habitação, lazer, circulação e trabalho. A cidade e o urbano seriam, portanto, a simples soma do habitat, o conjunto de funções básicas pré-determinadas pelo urbanismo funcionalista e pelo Estado burocrático. Esse reducionismo da vida individual e social, naturalmente complexa e diversa, faz, segundo Lefebvre, oposição ao habitar, pois este é entendido como parte da cidade, que o envolve (LEFEBVRE, 2001, p. 67). Lefebvre (2013, p. 344-345, tradução nossa) descreve o papel de arquitetos e urbanistas funcionalistas na produção do espaço (abstrato) da seguinte maneira:

Ao mesmo tempo, os arquitetos e urbanistas trazem - também como uma ideologia em ação - um espaço vazio, primordial, um continente que recebe conteúdos fragmentários, um meio neutro pronto para receber coisas separadas, pessoas e habitats. Em suma, a incoerência sob o signo da coerência, a separação e a disjunção na coesão, o fluido e o efêmero fazendo-se passar pelo estável, as relações conflituosas no seio da lógica aparente e do combinatório efetivo.

Essa produção do espaço mostra-se sob a lógica hierarquizada de imposições de cima para baixo, ou seja, do nível distante, Global (do Capital e do Estado) ao Misto (da cidade, mediador) ao nível Privado (das pessoas e do cotidiano) (LEFEBVRE, 1999). Deste modo, a esses problemas Lefebvre desenvolve, primeiramente, a noção de apropriação dos espaços como forma de desaliená-los e torná-los democráticos e verdadeiramente coletivos, pois com a apropriação dos espaços há, via de regra, a inversão dessa lógica de produção do espaço urbano. A apropriação é tratada por Lefebvre como mais do que uma questão a ser pensada, como para os arquitetos do Team 10, mas como uma categoria de análise. Para Lefebvre (1971, p. 210, tradução minha), "Habitar, para o indivíduo ou para o grupo, é apropriar-se de algo".

Segundo Lefebvre (2013, p. 346), a produção do espaço abstrato, estratégico, que contém a contradição inerente de ser homogeneizante e fragmentário, pode se tornar o local que engendra uma "falsa consciência" e, assim, "A Apropriação, que em qualquer forma, concreta e efetiva, deveria 
simbolizar-se (dar lugar a símbolos que a apresentem, que a façam presente) se vê significada e ilusória".

As apropriações cotidianas tornariam os espaços em lugares, retomando suas características supra e transfuncionais, o lúdico e o simbólico (GUTIÉRREZ, 2013, p. 45). Segundo Lefebvre (1971; 1999; 2001; 2013), há uma diferença clara entre habitar e habitat e que a lógica "operacional" com o qual a arquitetura tratou a questão da habitação a partir do final do século XIX fez com que o habitat se confirmasse em relação ao habitar. Para Lefebvre (2013), foi nesse período conhecido na França como belle époque (1871-1914, logo após a reestruturação haussmanniana de Paris) que há a desestruturação da forma tradicional de habitação que era, até então, configurada por edificações nas quais a burguesia ocupava os primeiros andares e o operariado o piso superior, sob os telhados. Essa forma implicava no compartilhamento de uma mesma localização por diferentes camadas sociais. Com a expulsão do operariado das áreas centrais, emerge o fenômeno de produção dos casebres nas periferias. Emergem também as fronteiras urbanas, as divisões territoriais da cidade e os limites "inferiores" da sociabilidade.

Foi então que se definiu o habitat com seus corolários: o volume mínimo habitável, quantificável em termos de módulos e trajetos; o equipamento igualmente mínimo e o entorno programado. $\mathrm{Na}$ verdade, o que se definiu assim, mediante aproximações sucessivas, foi o limite inferior de tolerância. Mais tarde, no século XX, os casebres tendem a desaparecer. No espaço das periferias, os chalés contrastam com os "conjuntos poligonais" tanto quanto as moradas opulentas se diferem dos sótãos dos pobres (LEFEBVRE, 2013, p. 352, tradução nossa).

O habitar, por sua vez, está ligado à vida cotidiana, ao uso que se dá dos espaços que complementem o sentido da habitação para além de sua função de abrigo. “O 'ser humano' (...) só pode habitar como poeta” (LEFEBVRE, 2001, p. 79), pois habitar significa mais do que ocupar o espaço, relaciona-se com a realização do próprio ser, é uma característica fundamental da condição humana (LEFEBVRE, 1971, p. 152). O habitar, portanto, pressupõe certa educabilidade, tendo em vista o caráter plástico dos seres humanos, sempre em desenvolvimento e aprendizagem (LEFEBVRE, 1999, p. 69). 
Ao comparar o habitar com a poesia Lefebvre pode parecer deslocar sua análise do ato de morar em direção ou com conotação mística, onírica, ou seja, com as características que comumente são atribuídas às artes. Ao lembrarmos de sua base metodológica materialista dialética baseada em Hegel, Marx e Nietzsche (LEFEBVRE, 2013; SCHMID, 2012), contudo, podemos inferir que Lefebvre, na realidade, vê a poesia como um conjunto de signos e significações que expressam a materialidade posta em ideias e palavras. Explicando de outra forma, o habitar, assim como a poesia, representa mais do que possuir algo, mas transformá-lo em uma expressão dos significados que aquela realidade concreta (socialmente produzida) tem para os seus moradores. O ato de habitar, assim como a realidade cambiante, deve ser observado como um movimento ao mesmo tempo próprio de quem habita (vive) e socialmente contextualizado e determinado, pois, como já vimos em relação à categoria trabalho, mesmo as necessidades e desejos são historicamente/socialmente determinados.

O habitat, em contrapartida, trata-se da habitação pensada apenas para o cumprimento de funções operativas básicas, que "nem ao mesmo se pode dizer que os atos funcionais elementares sejam animais", pois o habitat acaba "restringindo o ser humano a alguns atos elementares: comer, dormir, reproduzirse." (LEFEBVRE, 1999, p. 78). O habitat despreza ao que Lefebvre chama de o urbano, ou seja, o meio social em sua relação dialética com o espaço, tornandoos indissociáveis. Há, portanto, uma superficialidade de tratamento da complexidade do fenômeno humano e urbano (LEFEBVRE, 1971, p. 151).

Os objetos de bom ou mau gosto, saturando ou não o espaço da habitação, formando ou não um sistema, até os mais horrorosos bibelôs (o kitch), são a irrisória poesia que o ser humano oferece a si próprio para não deixar de ser poeta. Não é menos verdadeiro que essa relação do "ser humano" com o mundo, com a "natureza" e sua própria natureza (com o desejo, com seu próprio corpo) jamais foi imersa numa miséria tão profunda como sob o reino do habitat e da racionalidade pretensamente "urbanística". (LEFEBVRE, 2001, p. 80)

O habitat, ressalta Lefebvre, como "ideologia e prática", chega a negar a diversidade das maneiras de viver (LEFEBVRE, 2001, p. 78). Sua crítica é muito clara ao dizer que "O habitat foi instaurado pelo alto: aplicação de um espaço global homogêneo e quantitativo obrigando o 'vivido' a encerrar-se em caixas, 
gaiolas, ou 'máquinas de habitar'” (LEFEBVRE, 2001, p. 79). O habitat permite que a moradia seja apenas mercadoria, vista pelo seu valor de troca em detrimento de seu valor de uso. Resumidamente: "O habitat surge de uma descrição morfológica, é um quadro. Habitar é uma atividade, uma situação" (LEFEBVRE, 1971, p. 209, tradução minha).

Assim, a apropriação tem um sentido maior do que instrumental, o de reconhecimento do ser no objeto/espaço. Exemplificando de maneira simples, um objeto pode ser usado de diferentes formas com diferentes finalidades adaptação - porém a apropriação é fazer parte da construção daquele objeto, tendo o conhecimento de seu funcionamento e ver nele o reflexo de suas ações de forma que seja parte de sua identidade.

A apropriação chega a um novo patamar com o aumento da desigualdade social e da segregação socioespacial, reforçando a esfera política que permeia algumas de suas concepções, resultando em uma série de debates com revisões dos autores supracitados. É neste esteio que procuramos, a seguir, delinear um entendimento sobre a apropriação do espaço na atualidade.

Entende-se a apropriação como o processo dialético que vincula pessoas e espaços, dentro de um contexto sociocultural, e que parte dos níveis do indivíduo, do grupo e da comunidade até o da sociedade. Assim, quando existem relações e experiências com o espaço que desencadeiam significados, identidades e participações, dá-se a apropriação do espaço.

O uso reaparece em acentuado conflito com a troca no espaço, pois ele implica 'apropriação' e não 'propriedade'. Ora, a própria apropriação implica tempo e tempos, um ritmo ou ritmos, símbolos e uma prática. Tanto mais o espaço é funcionalizado, tanto mais ele é dominado pelos 'agentes' que o manipulam tornando-o unifuncional, menos ele se presta à apropriação. Por quê? Porque ele se coloca fora do tempo vivido, aquele dos usuários, tempo diverso e complexo. (LEFEBVRE, 2013, p. 389)

Há de se considerar que a multifuncionalidade pode se configurar em um fator de normatização de um espaço, tornando-o menos suscetível às apropriações novas. Contudo, a multifuncionalidade, levando-se em conta diferentes "ritmos" e "tempos", implica, via de regra, em um espaço mais propício às alterações de apropriações que os espaços venham a passar. A apropriação 
é, em si, um processo que se decorre no tempo e, por isso, mutável. Não se pode falar em apropriação de forma estática (a não ser em análises quantitativas que se proponham, de início, a limitarem-se à descrição de uma imagem do espaço). A apropriação é ação, é um movimento tanto para o indivíduo quanto para o espaço.

Vê-se, assim, que Lefebvre impõe um sentido simbólico para apropriação, no qual só pode ser estabelecido através do uso em um tempo, ou seja: só há apropriação quando há, no território, práticas sociais e, quanto maior a multifuncionalidade, maior a apropriação - para um grupo social - por atender a mais 'tempos' e proporcionar um sentido maior de obra. Não apenas isso, mas também por proporcionar o conflito democrático constante, dotando o espaço de conteúdo político. O contrário acontece com o valor de troca, de propriedade, em que prevalece a posse independente do uso e da identificação. O território no sentido de propriedade é um domínio que, como qualquer objeto, tem valor de compra e de venda.

O produto do trabalho que atenda às necessidades e possibilidades de uso são, pela mediação do dinheiro, transformados em mercadoria e adquirem valor de troca. Dessa forma, o dinheiro acaba por mediar a relação social de produção, alienando o trabalho que, como supracitado, é a força motriz de humanização segundo a teoria marxiana (FREITAS, 2015).

No âmbito da habitação, sobretudo a chamada Habitação de Interesse Social, a relação entre o valor de uso e o valor de troca ganham maior destaque. A habitação tem um valor de uso que realiza o valor de troca, com este último subordinando o primeiro na colocação da habitação como mercadoria. Este fato coloca o acesso à moradia como um direito, porém, ao mesmo tempo, o protagonismo da terra urbana nas dinâmicas do capital faz com que esse direito esteja submetido às questões de mercado e da economia política. A habitação, para o capital, é mera mercadoria, e seu valor de uso torna-a uma mercadoria de ainda maior valor. Portanto, a apropriação se coloca fora da questão da propriedade do espaço. O lugar apropriado não necessariamente é de propriedade do indivíduo ou grupo que dele se apropria. 
Aqui vista em sua aplicação positiva, a apropriação dos espaços deve ser democrática e coletiva. Contudo, há a apropriação no sentido negativo, quando há proibições objetivas ou subjetivas que delimitam territórios como pertencentes à um grupo ou classe social específico, como nos casos de espaços gentrificados e/ou elitizados. Segundo Lefebvre (2013, p. 355, tradução nossa), "A proibição é o reverso e o acobertamento da propriedade, da apropriação negativa do espaço sob um regime de propriedade privada".

A questão dos usos e pertencimentos a múltiplas temporalidades coloca o espaço público como local potencial de apropriação. Ele não está sujeito (teoricamente) a vontades de empreendedores individuais, mas submetido à ação das pessoas e do Estado ao qual determinado espaço faz parte. Um espaço apropriado, contudo, inverte a direção dos comandos e tem o potencial de fazer com que o Estado se submeta às vontades coletivas daqueles que de fato produzem esse espaço.

Como vimos no capítulo anterior, Lefebvre (2013) tem a compreensão da cidade como um espaço construído sobre o espaço natural. O autor nos lembra da compreensão de Marx sobre a natureza como uma "entre as forças produtivas" mas ressalta que Marx não caracterizou que o trabalho sobre a natureza pode ter duas formas: a da dominação e a da apropriação. A dominação da natureza implica a sua destruição, que não é inevitável, pois está em constante conflito com a apropriação, frisa Lefebvre (2013, p. 377).

Explicitando melhor, Lefebvre nos mostra que o espaço urbano e suas instalações constituem-se também como capital constante, ou seja, morto. Isso se dá assim como uma máquina para uma fábrica e, seguindo este raciocínio, assim como o capital constante é visto como um investimento, como um trabalho "morto" prestes a ser reapropriado pelo trabalho "vivo" (animado) para a produção de novas mercadorias, a cidade quando tomada como obra, quando apropriada, pode inverter a lógica da dominação do espaço e sobrepor o valor de uso ao valor de troca. Ademais, para o autor o espaço urbano contém a virtualidade de sua superação enquanto mercadoria, transformando-se pelas "exigências do corpo" em um "espaço diferente" (LEFEBVRE, 2013, p. 382), lúdico, utópico, compreendido finalmente enquanto obra. 
A "superação" é um item também importante de ser entendido na obra lefebvriana. Assim como Marx, Lefebvre se utiliza do termo Aufheben da língua alemã para explicar a profundidade do método dialético. Esse termo é uma palavra-conceito que tem um significado aparentemente dúbio, mas faz sentido dentro da teoria lefebvriana (SCHMID, 2012), pois Aufheben significa, ao mesmo tempo, "negação e superação; (...) preservação e colocação em um nível superior" (SCHMID, 2012, s/p). Lefebvre (apud SCHMID, 2012, s/p) afirmou:

É óbvio que este conceito não tem aquela simplicidade, clareza e sofisticação que o pensamento cartesiano nos leva a procurar nos conceitos. O que nós encontramos na origem desse conceito essencial? Um jogo de palavras e um trocadilho que não se traduz, nada formal, e talvez também nada que possa ser formalizado em um discurso perfeitamente coerente.

Dessa forma, a superação encontra-se no interior daquilo a ser superado. A teoria do espaço urbano sob a dialética lefebvriana conhece mas não necessariamente aceita a realidade como tal e, sabendo-se que toda ideia parte dos meios materiais (materialismo), procura demonstrar que a sua superação ou "colocação em um nível superior" se constituirá de dentro dessa realidade material (formada e reformulada em um constante processo dialético de significações); e se é a partir da realidade que a superação pode acontecer, podemos concluir que a realidade carrega consigo os meios de sua própria preservação, negação e superação.

Voltando ao termo obra podemos compreender que a obra ou o urbano como obra só pode se realizar a partir do uso, da apropriação (do resultado do trabalho não-alienado sem um agente particular determinante; trabalho este que inclui o planejamento, ou seja, as ideias sobre o que será realizado). Os usos, ou "as práticas espaciais" (LEFEBVRE, 2013), não são necessariamente o espaço apropriado. Essas práticas conformam o espaço material, mas podem ser "desvios" das funções para as quais os espaços foram designados sem que, contudo, seja verdadeiramente apropriado pelos usuários (LEFEBVRE, 2013, p. 215-216). Essas "desviações" podem tanto ser utilizadas como base para reformulações hierarquizadas dos espaços, aproveitando-se de um potencial mercadológico das novas funções "desviadas"; como também podem desencadear reapropriações, que são práticas espaciais geradoras de uma 
territorialidade coletiva independente do espaço enquanto mercadoria (idealizado e construído por e para a manutenção dos poderes instituídos, 0 Estado e as classes sociais dominantes). Tornam-se "espaços de prazer", mas somente de forma provisória as desviações põe fim à dominação (LEFEBVRE, 2013, p. 216)

Ou seja, somente a apropriação tira o caráter de produção e consumo mercadológicos do espaço urbano e torna-o próprio (apropriado, em um jogo de palavras) à população que exerce sobre ele suas práticas. A partir da apropriação pode-se idealizar que o espaço se torne cada vez mais próprio daqueles e para aqueles que o usam e, ao mesmo tempo, mais livres, pois retirados do domínio de agentes e classes sociais específicas. A idealização sozinha, contudo, representa a dotação de sentido, mas não a sua "colocação em um nível superior", o que só será alcançado com a aplicação do trabalho nãoalienado, ou seja, a materialização das ideias no sentido das necessidades e desejos daqueles que o idealizam e de seus corpos.

Podemos agora compreender que o espaço urbano pode ser utilizado como forma de preservação do status quo, como instrumento de manutenção das dominações de classe e das espaciais (lembrando da relação dialética conflituosa entre dominação e apropriação) ou, ainda, pode ser instrumento de sua própria superação, apropriado e tornado verdadeiramente próprio para a sociedade que o produziu e o reproduz constantemente. A apropriação, assim, é a forma das práticas espaciais que sinaliza para as possibilidades de tomada do espaço apropriado pela e para as pessoas, sendo elas a partir de então as idealizadoras e produtoras do espaço a partir dos conflitos constantes, construtivos e constitutivos de suas necessidades e desejos.

Atualmente o tema da apropriação do espaço é estudado dentro do campo da psicologia ambiental, desenvolvido dentro dos saberes da psicologia 69 (POL, 2016), a partir dos quais os estudos têm enfoque na influência dos

\footnotetext{
${ }^{69}$ Seu desenvolvimento, na verdade, pode ser separado em 3 ou 4 etapas, sendo a primeira do início do século XX (POL, 2016l).
} 
espaços nos comportamentos. Segundo Heimstra e McFarling (1978), a psicologia ambiental se preocupa com:

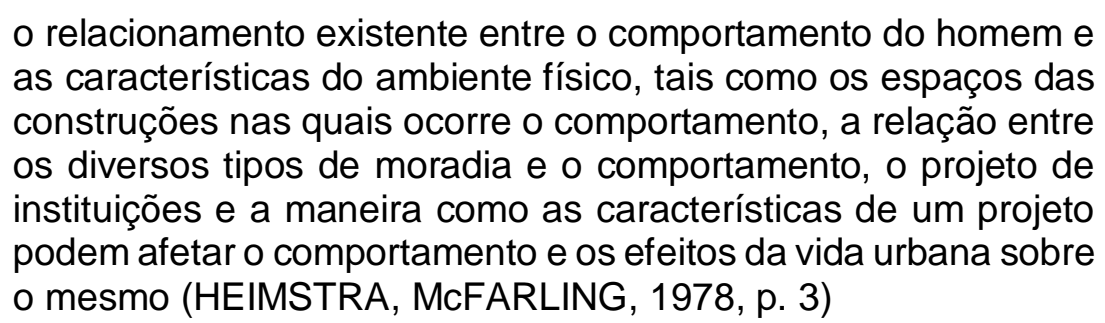

Pode-se considerar que, enquanto a psicologia ambiental se preocupa com as relações de causa-consequência psíquicas imediatas entre espaços e sujeitos, a apropriação trata das relações entre as pessoas e os espaços a partir da ação delas no espaço e em consequência dele em um movimento de produção e reprodução constante. Não nos deixa de interessar, obviamente, a influência da forma espacial (e todo o contexto histórico-social-cultural nela envolvidos) no comportamento humano, mas esta influência só nos interessa na medida em que propicia ou limita formas e processos de apropriação, de dar forma e sentido aos espaços pelos usuários, de tratá-lo com domínio significante, ou melhor dizendo: como obra.

Pela perspectiva da psicologia ambiental, no resultado provável da apropriação há a construção do "apego ao lugar". Esses espaços virtuais construídos, que são materializados no (ou pelo) espaço físico, explicam comportamentos respeitosos e perspectivas de futuro em relação aos lugares. Esse último é um elemento chave na análise pós-ocupação de pessoas em um conjunto habitacional, sobretudo para a HIS. Desta maneira, “(...) a apropriação do espaço é uma forma de entender a geração de vínculos com os 'lugares', o que facilita comportamentos ecologicamente responsáveis e a relação e a participação no próprio entorno." (MORANTA, POL, 2005. p.284, tradução nossa)

A psicologia ambiental, portanto, ao esmiuçar a apropriação, consegue determinar ações individuais como possibilidades de permanência e trabalho de melhoria dos lugares, algo importante de ser compreendido tendo em vista, sobretudo, a constante produção estatal de espaços habitacionais de massa, ou seja, de habitat. Deve-se fazer a ressalva de que para Lefebvre as 
determinações espaciais a partir das práticas e idealizações das pessoas que se apropriam dos lugares estão em condição sine qua non para a cidade como obra verdadeira de sua população, fruto do trabalho coletivo desalienado.

Assim, tendo em vista o contexto da inserção dessas pessoas em uma nova localidade e realidade, além do propósito da inclusão desses moradores como cidadãos de direitos por parte de uma ação que está dentro de uma política pública, estudos da natureza aqui proposta mostram-se importantes elementos de análise e compreensão de comportamentos socioespaciais e dos resultados de uma ação pública ligada tanto à promoção do acesso a direitos e à cidadania nas acepções contemporâneas inseridas no contexto de um Estado Democrático de Direito, quanto na promoção de uma sociedade mais próxima de entender e produzir sua própria realidade, revolucionária.

Hoje em dia já não bastam essas definições limitadas da revolução. Uma transformação da sociedade supõe a possessão e a gestão coletivas do espaço mediante uma intervenção constante dos 'interessados', com seus múltiplos, diversos e contraditórios interesses. Assim, pois, mediante a confrontação. Este já é patente nos denominados problemas do 'meio-ambiente', não sem risco de desvios e alterações (LEFEBVRE, 2013, p. 450451)

Assim, deve-se procurar relacionar os elementos propulsores (características culturais, sociabilidades, identificação simbólica e etc.) de apropriação e seus correspondentes espaços apropriados (a moradia, a rua, a praça, a escola, etc.) para um entendimento do processo em sua totalidade. Neste contexto dos processos de interação, o uso e a temporalidade do uso ganham papel central no processo de apropriação. Isso se dá pela qualidade do espaço de fazer parte da vida urbana. 


\section{4 viçosa: habitação e cidade}

A cidade de Viçosa é nacionalmente conhecida, sobretudo, por abrigar a Universidade Federal de Viçosa (UFV). O município faz parte da mesorregião da Zona da Mata mineira e dista cerca de 220 quilômetros da capital do estado, Belo Horizonte. Estima-se que a população viçosense tenha alcançado os 77 mil habitantes no ano de 2015 (IBGE, 2010). Contudo, por sua especialização funcional no setor de serviços (CARVALHO, 2014, p. 102), com destaque para o oferecimento de educação de qualidade nos níveis médio e superior através de suas instituições públicas e privadas, a cidade recebe diariamente um grande número de estudantes e profissionais do terceiro setor que residem em pequenas cidades da macrorregião de Viçosa. As instituições de ensino são o principal fator de atração da cidade, o que explica a população "flutuante", estimada em quase 20 mil pessoas (MARIA; FARIA; STEPHAN, 2014). É também o setor responsável por movimentar a economia local. A UFV sozinha conta com mais de mil professores e cerca de 18 mil estudantes.

Estima-se ainda que cerca de um terço da população esteja matriculada em instituições de ensino de diferentes níveis, sendo este o principal motivador do lema "Viçosa, Cidade Educadora", utilizado por gestões da prefeitura municipal e disseminado entre a população. A população flutuante configura um grave problema para o município, que tem seus serviços superlotados sem um repasse proporcional do Fundo de Participação dos Municípios (FPM - uma das principais fontes de verba para o município), o que gerou, recentemente, reclamações por parte da administração pública frente ao $\mathrm{IBGE}^{70}$.

Apesar do número de habitantes enquadrá-la como cidade pequena, de acordo com a literatura que venha a ser utilizada para a análise, a centralidade

\footnotetext{
70 A atual gestão da PMV pleiteou um encontro com representantes do IBGE para requisitar a adição da população flutuante na contagem dos munícipes, tendo em vista um repasse maior por parte do FPM, que é balizado pelos números divulgados pelo IBGE. Ver mais em: <http://www.vicosa.mg.gov.br/arquivos/imprensa/prefeito-de-vicosa-requer-que-flutuantessejam-considerados-nas-estimativas-do-ibge> Acessado em: 11 ago 2016.
} 
sub-regional protagonizada pela cidade faz dela uma cidade média propriamente dita, como esclarece Carvalho (2014). Ainda segundo o autor, a influência exercida pela cidade que a "eleva" à categoria de cidade média deve-se, sobretudo, à sua oferta de serviços no setor educacional de ensino superior e de pós-graduação, tendo em vista que as características técnico-informacionais, bem como o nível médio de educação de sua população são dois importantes fatores que compõe diferentes critérios de avaliação do papel de uma cidade em relação à sua rede (CARVALHO, 2014).

$\mathrm{O}$ destaque aqui reservado à UFV deve-se à centralidade dessa instituição na produção do espaço urbano da cidade. A instituição tem em seu histórico um processo de expansão que foi acompanhado - não acidentalmente - pelo crescimento populacional e expansão da malha urbana da cidade, como veremos adiante. "Em Viçosa são as exterioridades da atividade universitária que potencializam o seu processo de urbanização" (HONÓRIO, p. 40)

Devido às características morfológicas da região e aos interesses imobiliários, a expansão da UFV e da cidade resultou em um espaço urbano de caráter geral socialmente segregado (RIBEIRO FILHO, 1997; COELHO e CHRYSOSTOMO, 2015), com a expansão da malha para regiões periféricas e de encostas, em ocupações populares em grande parte ilegais, contrastando com áreas de grande adensamento e posterior verticalização, como no centro da cidade (ZACCHI, 2014; PAULA, 2013). Resultou também na permanência ou agravamento de carências de serviços e de qualidade de vida para os bairros mais pobres. Até mesmo os bairros com estruturas melhores sofrem com o trânsito intenso diariamente e até mesmo com a falta d'água em certos períodos. Como resultado de más administrações públicas, temos o setor imobiliário como principal agente transformador do espaço urbano e, em consequência, há especulação imobiliária e perde-se em qualidade edílica e urbana com construções que não obedecem nem mesmo as legislações federais. 


\subsection{Viçosa e a UFV: um breve histórico}

A história de ocupação da área que hoje compõe a cidade de Viçosa é relativamente recente. Isso aconteceu, segundo Carneiro (2008) pelo fato de a região ter sido considerada pela Coroa, durante o período colonial, como local hostil, de modo a desestimular a ocupação das terras próximas à zona de extração aurífera, conferindo, assim, maior controle da saída de pessoas e do ouro minerado. A região era, então, ocupada por população indígena (os Puris) considerada agressiva, o que facilitava a obediência aos desígnios da Coroa. Outro fator que ajudou a Coroa foi a geografia da Zona da Mata, que pertence aos "mares de morros" mineiros, com densa floresta de Mata Atlântica em boa parte de seu território. A ocupação da região da Zona da Mata deu-se, portanto, de modo lento e apenas a partir do declínio do ciclo do ouro, em meados do século XVIII.

Como afirma Ribeiro Filho (1997), não se tem registro das ocupações que deram origem à vila que viria a ser Viçosa até o final do século XIX, quando se tem as primeiras documentações. Especula-se, porém, que a partir da doação de terras à Igreja estabeleceu-se o loteamento e ocupação de áreas próximas às edificações religiosas. A primeira dessas edificações onde hoje é a Rua do Passos (em referência à Capela do Senhor dos Passos) e a segunda ao lado da atual Igreja Matriz de Santa Rita. A segunda edificação, por ocupar área plana, propiciou o traçado de ruas em um esquema de castrum (acampamento militar romano), formando uma pequena centralidade que atraiu a construção de residências, tendo em vista que morar próximo a uma igreja conferia importância às famílias (VALVERDE apud CARVALHO, 2014, p. 54). Uma dessas residências veio a ser da família Bernardes e hoje abriga o Museu Casa Arthur Bernardes ${ }^{71}$, guardando a memória do filho ilustre da cidade que se tornou presidente do país entre 1922 e 1926, Arthur da Silva Bernardes (1875 - 1955).

Apenas em 1876 a vila de Santa Rita do Turvo (rio que corta parte do município) foi elevada à categoria de cidade, tendo como primeiro nome o de Viçosa de Santa Rita (Lei Provincial n².216, de 03-06-1876). A origem do nome

71 O Museu está atualmente sob o controle da Universidade Federal de Viçosa. 
é motivo de debate, não havendo uma versão definitiva para a adição do "Viçosa" ao nome. Especula-se que possa ser pela visita de Dom Viçoso, bispo de Mariana-MG, ou ainda uma homenagem à Viçosa de Portugal, localidade de origem de parte dos colonos (CRUZ, 2014).

A cidade (Figura 06) estabeleceu-se como um pequeno núcleo de produção agrária, com a base da economia na produção de café e sem maior destaque regional, pertencendo perifericamente à rede de cidades ligadas à capital Rio de Janeiro através de Juiz de Fora (CARVALHO, 2014). Em 1885 a Estrada de Ferro Leopoldina chega à cidade, conectando sua produção cafeeira à economia regional. A estrada de ferro foi prolongada, segundo Carneiro (2008, p. 38) e Rangel ${ }^{72}$, por influência do então deputado liberal Carlos Vaz de Mello (feito que the rendeu homenagens como seu nome em uma das principais ruas da cidade).

Figura 06: Vista do centro de Viçosa em 1898

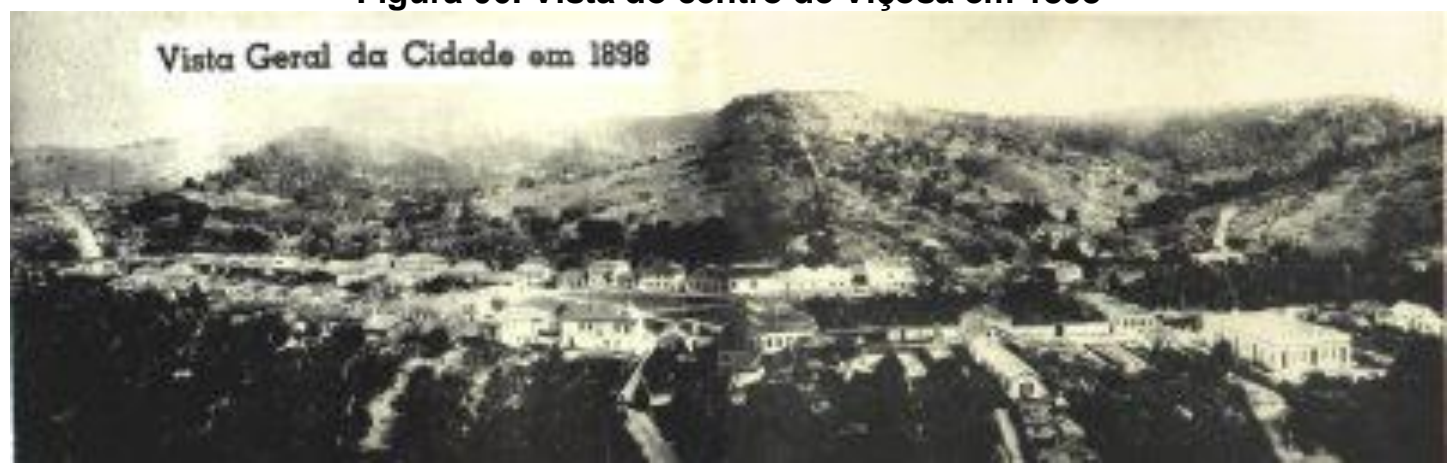

Fonte: <http://www.dpi.ufv.br/funcion/altino/fotos_vicosa.htm> Acesso em: 18 ago 2016.

A estrada de ferro foi um fator de conexão não apenas comercial, mas também para o intercâmbio de pessoas, o que permitiu a atração de trabalhadores e comerciantes migrantes italianos e libaneses (PANIAGO, 1990), através do incentivo do Estado à interiorização do país e da recente conexão da produção agroexportadora. À época, existiam duas fábricas de tecido. Contudo, a industrialização da cidade não vingou e as duas fábricas foram fechadas e a economia foi regida pela produção agrária cafeeira, ainda forte na época e que era refletida no desenvolvimento urbano da cidade (CARVALHO, 2014). A

72 Publicado em: < http://opassadocompassadodevicosa.blogspot.com.br/> Acesso em: 11 ago 2016. 
estrada teve seu alcance ampliado em 1914, com a construção da ferrovia dentro da atual região central, pois anteriormente distava seis quilômetros do centro.

A estrada de ferro constituiu-se com um fator de atração para a ocupação do espaço urbano da região central, influenciando no desenho do espaço urbano juntamente com os elementos naturais, como o Ribeirão São Bartolomeu e a conformação geomorfológica da cidade. Como é comum em cidades mineiras que cresceram sob a influência de estradas de ferro e suas estações, em Viçosa também pode-se observar a ocupação linear na região de fundo do vale, acompanhando o traçado da linha férrea e dos principais cursos d'água.

Assim como em outras cidades do país, a urbanização da cidade foi um meio de concentrar a produção cafeeira que seria escoada para o exterior através da estrada de ferro. A cultura cafeeira, contudo, teve grande declínio no primeiro quadrante do século $X X$, o que se refletiu no desenvolvimento de Viçosa. Exemplo disso é que a Igreja Matriz que teve o início de sua construção ainda no auge do café, ficou por quatro décadas inacabada (PANIAGO, 1990). Anos mais tarde, veio a ser demolida para a construção da atual Igreja Matriz de Santa Rita, elemento urbano de destaque no centro da cidade ainda hoje, mesmo com a intensa verticalização pela qual o centro da cidade tem passado.

Segundo Paniago (1990), a primeira intervenção urbana de expressão depois da emancipação da cidade foi a construção da Avenida Santa Rita, em 1900. A abertura da via foi inspirada em conceitos urbanísticos considerados modernos, com o caráter de boulevard aplicado na então capital do país, o Rio de Janeiro, e também na construção da recente capital do estado de Minas Gerais, Belo Horizonte (CARVALHO, 2014). É importante salientar que a abertura da via se deu juntamente com o loteamento do terreno e a imediata doação dos lotes às famílias que estivessem em condições financeiras de iniciar a ocupação no prazo de três meses. Esse fato indica, segundo Ribeiro Filho (1997), uma troca de favores políticos entre as elites locais. A Santa Rita também pode ser considerada a primeira intervenção pública geradora de segregação, visto que a doação de terrenos estava condicionada às famílias de maior poder econômico. 
A chegada da estrada de ferro ao centro da cidade, em 1914, e a construção do Patronato Agrícola (futura Escola Superior de Agricultura e Veterinária, a ESAV), em 1926, foram os principais fatores de crescimento da cidade no início do século XX. À época, em 1916, a cidade contava com uma população de dois mil habitantes distribuídos em cerca de 330 edifícios. Contava ainda, em seu pequeno inventário urbano, com cinco praças e nove ruas (RIBEIRO FILHO, 1997, p. 110). Ainda em 1916 foi criado o Colégio Viçosa, importante instituição de ensino básico que acolhia estudantes de Viçosa e região, atraindo pessoas até mesmo de outros estados, devido sua qualidade e proximidade com a ESAV. A população era majoritariamente rural e em 19300 município apresentava 800 edificações concluídas ou em construção.

A construção da ESAV se deu a partir do decreto Lei ํo 761 do então Presidente do Estado de Minas Gerais, Arthur Bernardes, em 1920 (Figura 07). A construção ocorreu entre 1922 e 1926 e, para o planejamento e administração da escola, foi convidado o Professor Dr. Peter Henry Rolfs, da Universidade da Flórida. O funcionamento da instituição deu-se a partir da criação do curso de Agricultura e do início das atividades no ensino fundamental e médio que também ocorriam na ESAV, ainda em 1927. Em 1932 o curso de Veterinária teria o seu início.

Em 1948 a ESAV foi ampliada e passou a fazer parte da UREMG (Universidade Rural do Estado de Minas Gerais), junto com cursos oferecidos em Belo Horizonte. Em 1958, firmou parceria com a Universidade de Purdue, dos EUA. Essa parceria foi responsável pela ideia pioneira de criação dos primeiros cursos de "pós-graduação stricto sensu, no modelo norte-americano do Master of Science ou Magister Scientiae (MS), o qual veio a ser posteriormente adotado, com algumas modificações, no país" (PDI, 2011, p. 15), em 1961.

Em 1965 a UFV cria o Colégio Universitário (COLUNI-UFV), que em 2001 passou a chamar-se Colégio de Aplicação. Essa escola tem suas atividades direcionadas ao ensino médio gratuito e foi por diversas vezes considerada a melhor instituição de ensino médio pública do país. Os 150 alunos que são admitidos todo ano (nos números atuais) são, em grande parte, provenientes de 
fora de Viçosa, fazendo do COLUNI outro fator de atração e participante da economia local, pois é o responsável pela abertura de "cursinhos" preparatórios visando o processo seletivo do Colégio.

Figura 07: Vista para os principais edifícios da UFV na década de 1920

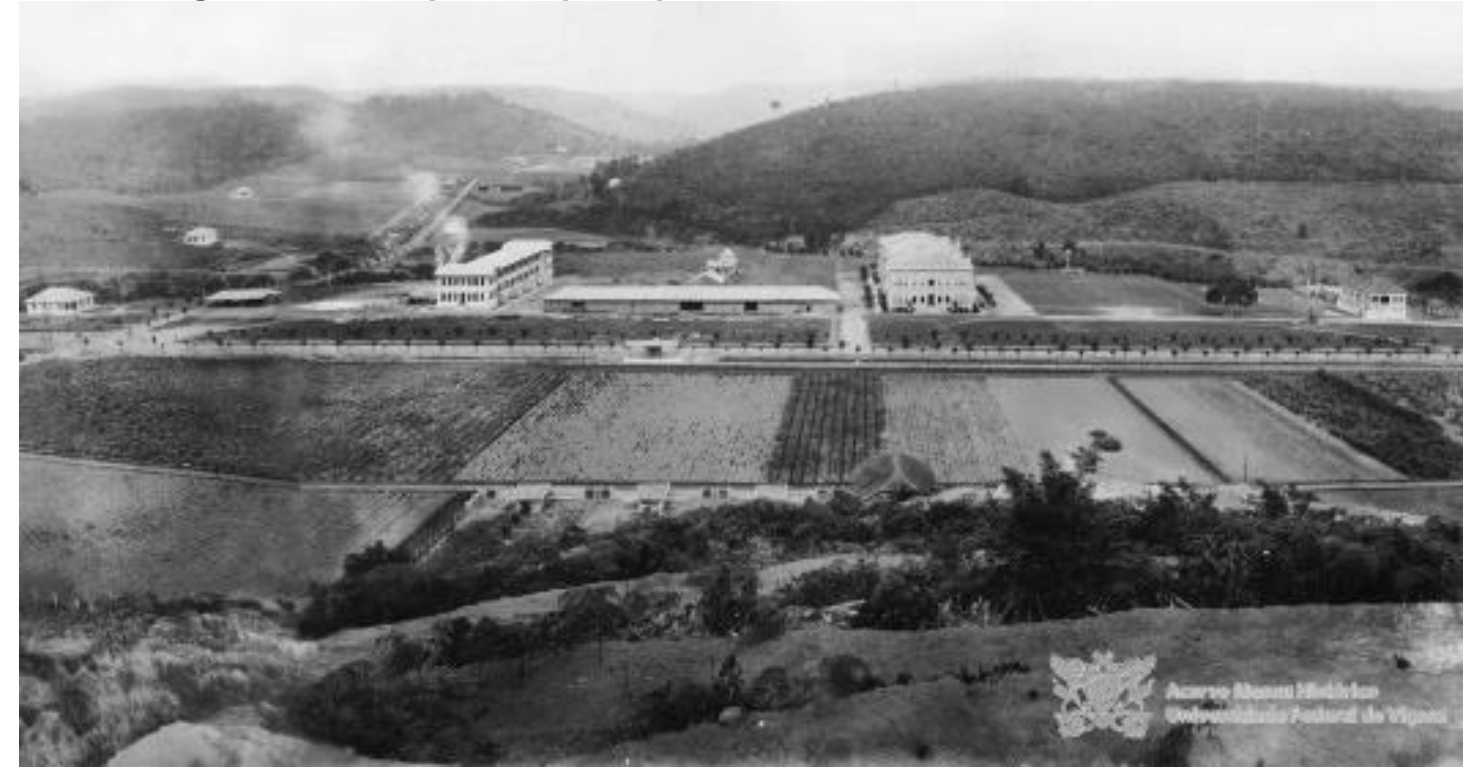

Fonte: <http://www.vitruvius.com.br/revistas/read/arquitextos/11.132/3881> Acesso em: 18 ago 2016.

Figura 08: Vista da Praça central Silviano Brandão, na década de 1940

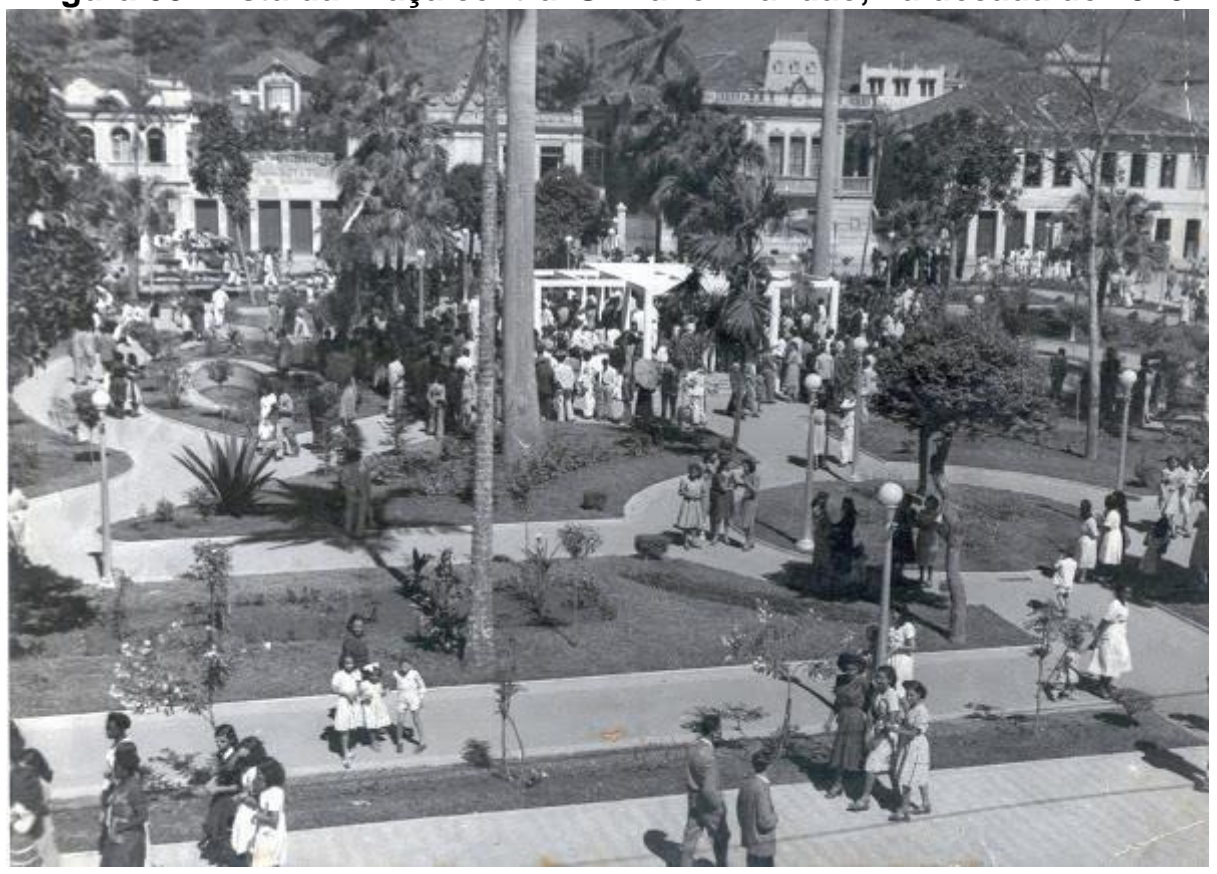

Fonte: Foto publicada no Museu Virtual de Viçosa (plataforma online colaborativa de fotos da cidade)

Acesso em: 18 ago 2016. 
Temos, ao final da década de 1960, um fato histórico de maior importância para a UFV na sua relação com a cidade. Até então, a instituição contava com "três cursos de graduação e oito de pós-graduação em nível de mestrado, totalizando 236 alunos. O doutorado foi iniciado em 1972" (PDI, 2011, p. 15). Em 1969 a UREMG torna-se Universidade Federal de Viçosa a partir de decreto (no 64.825) do então presidente Arthur da Costa e Silva, no início do último período militar. A partir de então, a UFV passa por um rápido processo de expansão, criando 16 cursos de graduação, sete de mestrado e quatro de doutorado, o que levou ao resultado de 4.152 alunos em cerca de 10 anos (PDI, 2011, p. 15). Soma-se a isso a ampliação do quadro de professores e técnicos administrativos. O processo de expansão da UFV foi continuado nas décadas de 1980 e 1990 sem, contudo, gerar impacto tão grande e rápido quanto na década de 1970.

Já nos anos 2000 a UFV passou por outro grande processo de expansão com a criação de 12 cursos de graduação no início da década, além de seis de mestrado e outros seis de doutorado. Ao final da década, com o programa do Governo Federal de Apoio a Planos de Reestruturação e Expansão das Universidades Federais, o REUNI, a UFV teve seu quadro de alunos ampliado nos cursos já existentes e com novos cursos, sobretudo das áreas da licenciatura. A expansão deu origem aos campi universitários situados em outras cidades.

Atualmente, cerca de 18 mil alunos (UFV, 2017) 73 $^{73}$ estão matriculados na universidade, a grande parte desses reside ou exerce suas atividades rotineiras em Viçosa. Se observarmos, então, a proporção da população estudantil apenas dessa instituição, podemos apontar para alguns impactos gerados por ela para o tecido urbano e social da cidade (Figura 09). Veremos, a seguir, a produção do espaço urbano viçosense e sua relação com a UFV e seus períodos de expansão.

${ }^{73}$ Dados de 2016. Estudantes de ensino médio, superior, pós-graduação e pós-doutorado apenas no campus de Viçosa. Disponível: <http://ruf.folha.uol.com.br/2013/perfil/universidadefederal-de-vicosa-ufv-31840.shtml> Acessado em: 11 jun. 2018. 
Figura 09: Vista aérea da cidade para a UFV. Foto do início dos anos 2000.

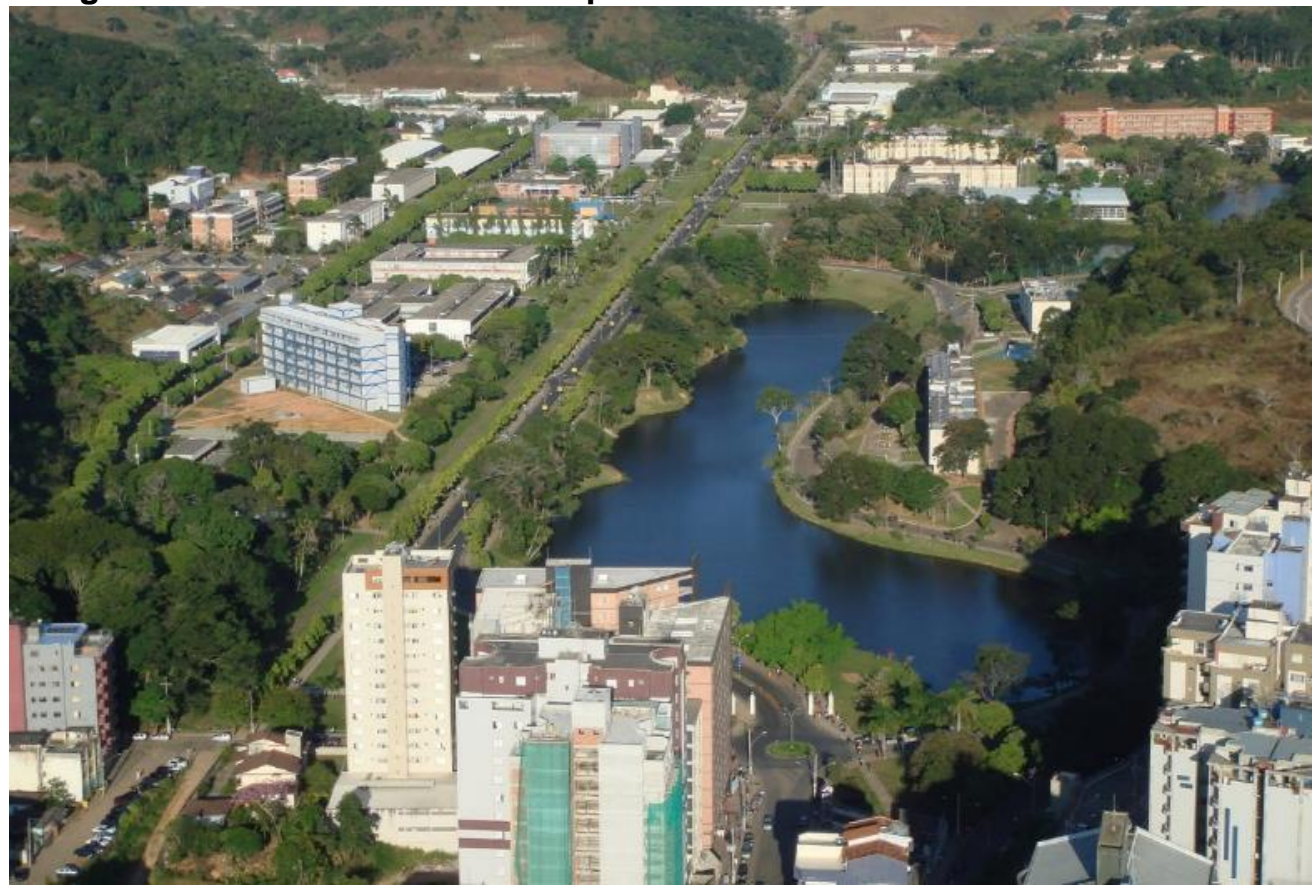

Fonte: <http://www.skyscrapercity.com/showthread.php?t=1518228> Acesso em: 18 ago 2016.

\subsection{Mercado imobiliário e a produção do espaço segregado}

A criação da Universidade Federal de Viçosa impactou sobremaneira no crescimento urbano do município. A instituição escolheu como terreno uma das poucas áreas planas próximas ao centro da cidade (Figura 10 e Mapa dos bairros do entorno) que, como supracitado, contava com uma pequena população urbana à época. Assim, a UFV constituiu-se em uma barreira à expansão da cidade em uma área privilegiada, que permitiria uma distribuição melhor dos espaços habitados. Com isso, e a partir da centralidade da instituição na vida urbana de Viçosa, as expansões urbanas, tanto legais quanto ilegais, passaram a ocupar áreas de encostas, muitas delas com inclinação superior ao que hoje considera-se como limite (30\%, por lei federal $n^{\circ} 6766$, de 1979).

Viçosa apresenta um histórico de intervenções urbanas e legislativas da municipalidade ou de particulares que podem ser colocados como modificadores da configuração urbana (Viçosa apresenta um histórico de intervenções urbanas do executivo e do legislativo ou, mesmo, de inciativa de agentes privados e particulares avulsos que conformaram e interferiram na configuração urbana) e 
como fatores que geraram espaços de segregação imposta ou desejada (nesse caso, tem-se os condomínios e bairros voltados às famílias de alta renda). Ribeiro Filho (1997) demonstra que desde o início do século XX podemos observar medidas que geraram segregação urbana.

Figura 10: Imagem de satélite destacando a fronteira entre a malha urbana de Viçosa e a UFV

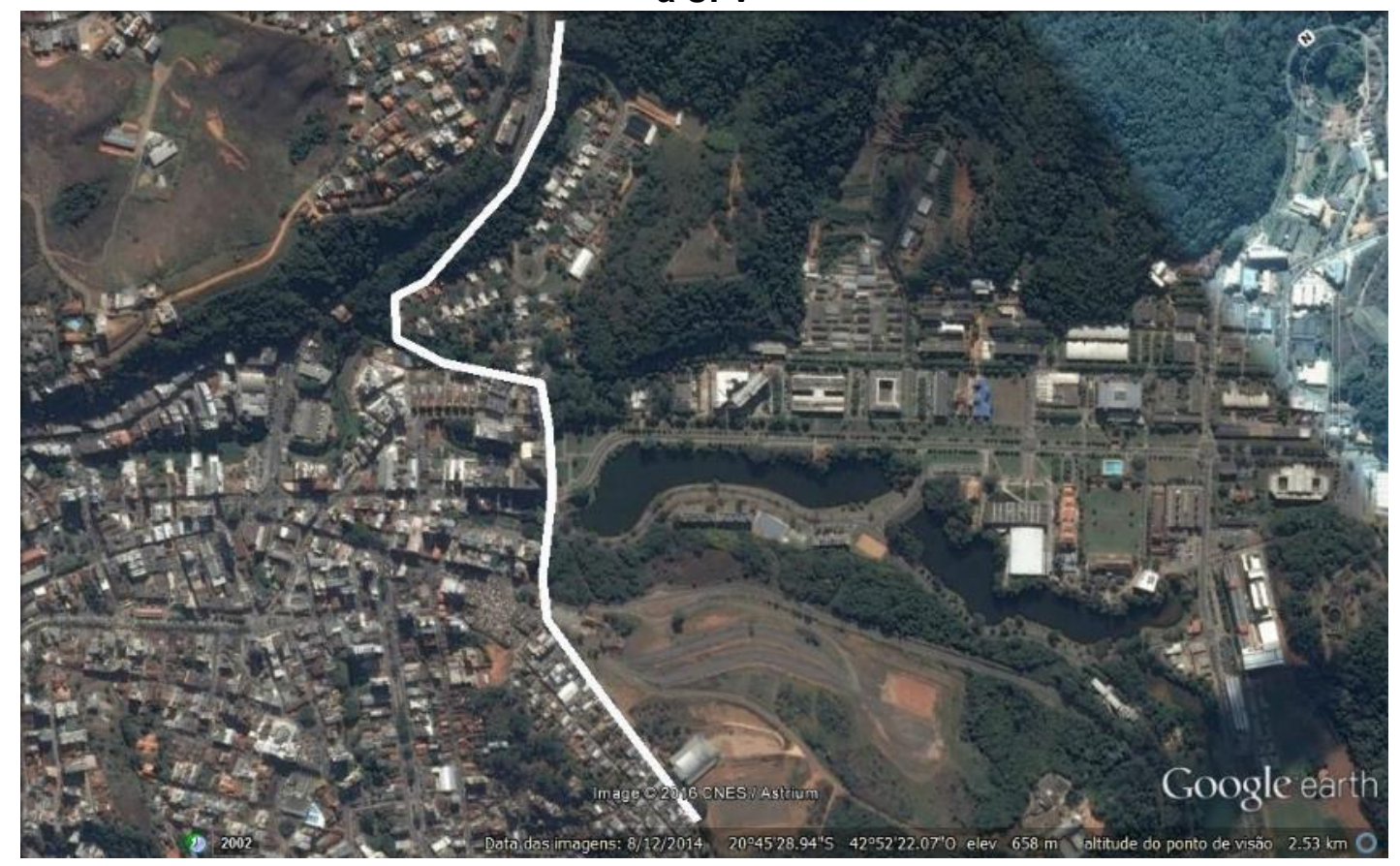

À esquerda da linha branca, parte da cidade. À direita, parte do campus da UFV. Fonte: Montagem do autor a partir de imagem do Google Earth Acesso em: 18 ago 2016.

Ainda na década de 1910, têm-se a abertura da Avenida Bueno Brandão, conhecida atualmente como "Balaústre", devido à balaustrada que compõe o guarda-corpo de um lado da avenida. Do outro lado houve um loteamento destinado à construção de residências, mediante certo padrão construtivo designado por resolução municipal. A resolução demonstra dois aspectos interessantes: a tentativa de se instituir um padrão arquitetônico para compor a paisagem urbana do centro da cidade, além de selecionar os moradores (ainda mais) pela renda, tendo em vista que deveriam obedecer aos parâmetros estéticos.

Na década de 1920, podemos destacar as resoluções dispostas pela municipalidade sobre aspectos de salubridade e sua fiscalização nos imóveis da 
cidade, claramente inspiradas no urbanismo higienista em voga no Brasil da época. "Nesta época, a distribuição dos serviços públicos já se mostrava deficiente, principalmente para os segmentos sociais mais pobres, visto que nem todas as edificações eram servidas por água e esgoto" (RIBEIRO FILHO, 1997, p. 110). Nas décadas seguintes (1930 a 1950), ainda não houve intervenções urbanas relevantes, sendo um período no qual apenas se destacam desmembramentos da área do município, que passaram a fazer parte dos municípios vizinhos (CARVALHO, 2014). A cidade teve apenas a abertura de novos logradouros e a consolidação dos largos, praças, ruas e avenidas já existentes e recém-abertas. Ribeiro Filho destaca os motivos econômicos e políticos que levaram a cidade a uma estagnação em seu crescimento e desenvolvimento:

[...] o esgotamento da produção cafeeira - base da economia local - não só na cidade como em todo o Brasil e a derrota política do ex-presidente, que o levou ao exílio ${ }^{74}$ e ao desprestígio político, por todo o período Vargas. Estes fatores, com certeza, contribuíram para o isolamento e a estagnação da cidade. (RIBEIRO FILHO, 1997, p. 116)

A estagnação também teve reflexos na desigualdade espacial. Em meados do século XX a cidade apresentava dois terços de suas ruas e avenidas sem pavimentação e quase a metade dos 1.480 edifícios não contavam com o abastecimento de água. Ou seja, não houve urbanização ou ampliação dos serviços e infraestruturas públicas que alterassem a realidade de desigualdade espacial vivida no município. Mesmo com a presença de pequenas indústrias, o município continuava com sua base econômica voltada à agricultura, predominantemente de característica familiar de subsistência (RIBEIRO FILHO, 1997). Dessa forma, o êxodo rural característico do Brasil das décadas de 1950 e 1960 não teve desdobramentos dentro da porção urbana da cidade, não alterando o quadro urbano viçosense até o início da década de 1970.

Cabe destacar, também, a primeira lei municipal de parcelamento do solo ( $n^{\circ} 280$ de 1956), aprovada em 1956 que, segundo Ribeiro Filho (1997, p. 126-

\footnotetext{
$74 \quad$ Arthur Bernardes participou de movimentos políticos combatidos por Getúlio Vargas. Fato que ainda hoje faz parte do imaginário da população viçosense, pois Arthur Bernardes, dizse, foi obrigado a procurar abrigo em fazendas de amigos pela região. Segundo Paniago (1990), o exílio aconteceu em dezembro de 1932.
} 
127) abriu brecha para que a prefeitura decidisse se exigiria ou não contrapartidas dos loteadores para a municipalidade. Desta maneira, as elites econômicas poderiam negociar diretamente com os representantes políticos, dando espaço para um descumprimento "legal" da legislação. Foi averiguado pelo autor que grande parte dos loteamentos realizados sob a vigência dessa legislação não destinou espaços para a implantação de serviços, equipamentos e infraestruturas urbanas públicas. Há casos de não cumprimento da legislação até mesmo em relação à largura dos logradouros. Fato que deixou como herança a exígua dimensão dos espaços para a circulação de automóveis e, principalmente, pedestres no município. Como revela ainda Ribeiro Filho (1997, p. 127), as consequências do descumprimento dessa e de outras legislações de diferentes esferas (municipal, estadual ou federal) são vistas ainda hoje:

O descumprimento desses artigos acarretou em graves prejuízos para a cidade, na medida em que a proporção entre espaços públicos e privados ficou ainda mais desequilibrada. A quantidade de espaços privados ficou muito maior do que a de espaços públicos, e os poucos espaços públicos que já existiam na cidade foram apropriados ao longo dos anos, em parte pelo privado, com a conivência do poder público.

Essa permissividade e/ou ineficiência da gestão pública no cumprimento da lei acarretou ainda outros problemas, como a falta de espaços para a implantação de equipamentos públicos necessários para o atendimento das populações dos bairros loteados sob a vigência dessa legislação:

A inexistência de áreas públicas nos bairros Santo Antônio e Arduíno Bolívar, por exemplo, levaram o poder público a comprar lotes de particulares para instalação de equipamento público. De acordo com a legislação que estava em vigor, os loteadores destes dois bairros deveriam ter destinado ao poder público áreas para instalação de equipamentos de lazer; no entanto, o poder público não as exigiu, ou, se exigiu, não as recebeu, e, mais tarde, teve que comprá-las para atender reivindicações da própria comunidade. (RIBEIRO FILHO, 1997, p. 169)

Ainda em 1956, foi publicado o primeiro Código de Obras da cidade (lei no 283 de 1956) que também não considerava as desigualdades espaciais e a diversidade funcional das áreas urbanizadas, caracterizando um instrumento que não refletia sobre a realidade urbana e nela não foi efetivada. Somado a isso observa-se a falta de rigor pela municipalidade no cumprimento das legislações, o que permitiu abusos por parte de loteadores e construtores, destituindo o poder 
real do instrumento. Dessa forma, "a expansão horizontal da cidade se deu à revelia da lei e com a conivência do poder público, que aprovou os projetos de loteamento, mesmo em desacordo com as suas determinações" (RIBEIRO FILHO, 1997, p. 127).

As décadas de 1950 e 1960 apresentam ainda a abertura de logradouros, pequenas intervenções urbanas de calçamento e alargamento de vias e a consolidação de logradouros existentes através da ocupação e conexão destes aos logradouros mais antigos (Figura 11). Porém, o fato de maior relevância cabe ao final da década de 1960, quando a Universidade foi federalizada. O quadro de alunos da instituição foi multiplicado em poucos anos (PDI, 2011), o que gerou mudanças não só dentro da UFV, mas também para a cidade. O mercado imobiliário foi aquecido, assim como a economia interna.

Figura 11: Imagem aérea de Viçosa na década de 1950

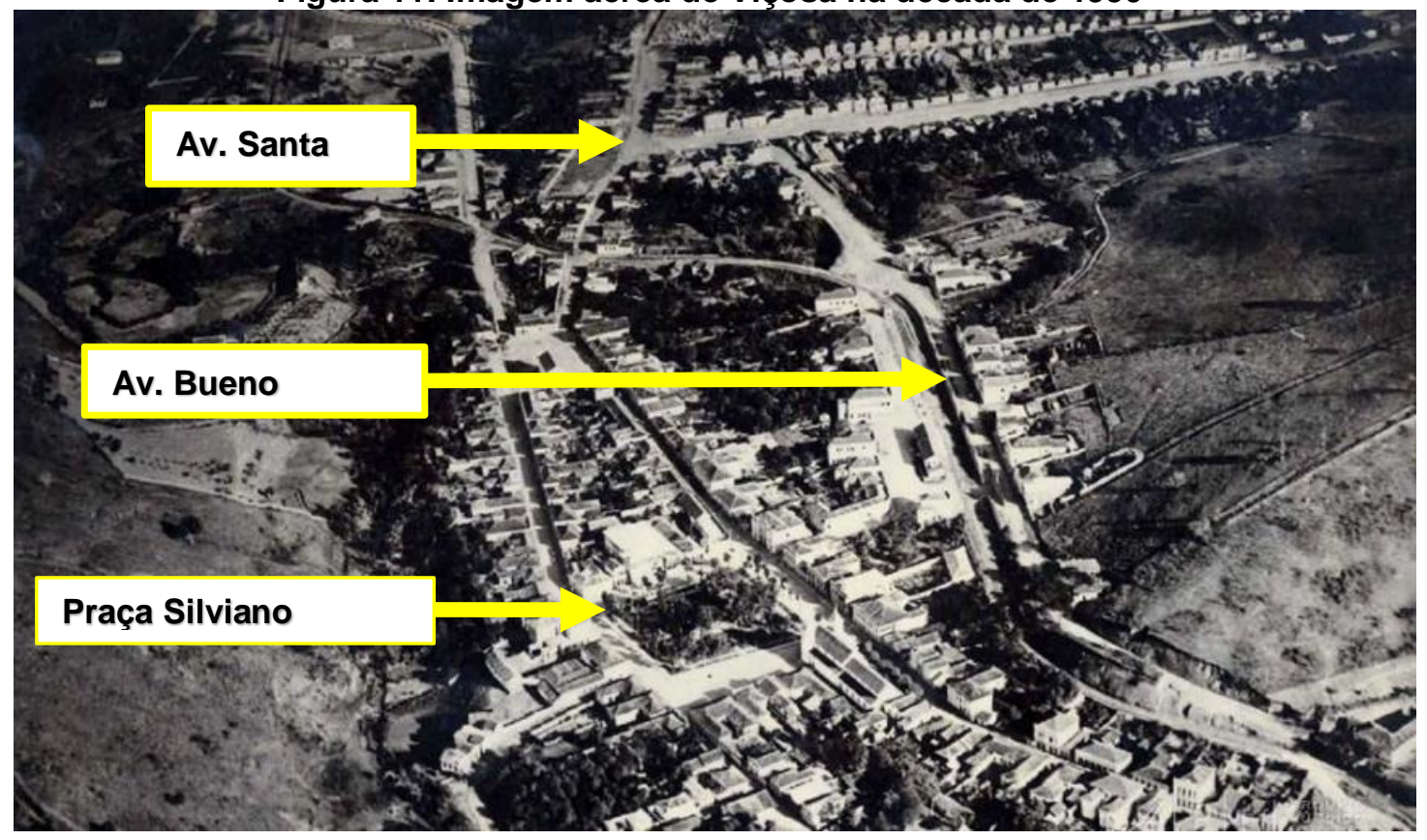

Fonte: Autor, modificado de foto publicada no Museu Virtual de Viçosa Acesso em: 18 ago 2016.

Observa-se um acréscimo de 65,5\% da população urbana na década de 1960 (RIBEIRO FILHO, 1997, p. 137) e um crescimento próximo a 50\% na população total da cidade entre as décadas de 1970 e 1980. No mesmo período a população urbana quase dobrou, devido à movimentação da economia que atraiu parte da população rural local, como pode ser observado nas Tabelas 03 e 04 a seguir. Fatos que se deram concomitantes a uma mudança estrutural a 
nível nacional da década de 1960, com a mudança de grande parte da população do meio rural para o urbano, principalmente para grandes centros urbanos, Viçosa também contou com um esvaziamento do campo e incremento da população urbana. Contudo, diferentemente do contexto dos grandes centros, 0 acréscimo se deu pela expansão das atividades do setor de serviços, com a federalização da UFV.

Tabela 03: Crescimento populacional de Viçosa

\begin{tabular}{|c|c|c|c|c|c|c|}
\hline \multirow{2}{*}{ Ano } & \multicolumn{2}{|c|}{ População Urbana } & \multicolumn{2}{c|}{ População Rural } & Total & Aumento \\
& Absoluto & $\%$ & Absoluto & $\%$ & & total \\
\hline $\mathbf{1 9 6 0}$ & 9.221 & 44 & 11.625 & 56 & 20.846 & -------- \\
\hline $\mathbf{1 9 7 0}$ & 17.000 & 66 & 8.784 & 34 & 25.784 & $24 \%$ \\
\hline $\mathbf{1 9 8 0}$ & 31.179 & 81 & 7.507 & 19 & 38.686 & $50 \%$ \\
\hline $\mathbf{1 9 9 1}$ & 46.456 & 90 & 5.202 & 10 & 51.658 & $33 \%$ \\
\hline $\mathbf{2 0 0 0}$ & 59.792 & 92 & 5.062 & 8 & 64.854 & $25 \%$ \\
\hline $\mathbf{2 0 1 0}$ & 67.305 & 93 & 4.915 & 7 & 72.220 & $11 \%$ \\
\hline $\mathbf{2 0 1 5}$ & -------- & ------- & ------- & ------- & 77.318 & $7 \%$ \\
\hline
\end{tabular}

${ }^{\star}$ Estimada

Fonte: Autor, baseado em dados do IBGE Cidades. 2015.

Ver mais em:

$<$ http://cidades.ibge.gov.br/xtras/perfil.php?lang=\&codmun=3171303>

Para se ter uma ideia do impacto econômico para o município, os funcionários da UFV correspondiam no início da década de 1970 a 27,6\% da população economicamente ativa (PEA) urbana (RIBEIRO FILHO, 1997, p. 141). Esta década foi, portanto, marcada por grandes mudanças territoriais urbanas. O crescimento da UFV também atraiu pessoas para os trabalhos de base, trabalhadores necessários para a construção de novas instalações na universidade e de novos edifícios na cidade. Essas pessoas, por não disporem de renda adequada, passaram a ocupar de forma irregular as encostas de morros situados o mais próximo possível do centro da cidade e da Universidade, configurando o crescimento também de bairros populares e favelas.

Tabela 04: Loteamentos e expansões de bairros registrados na cidade da década de 1950 a 1980 


\begin{tabular}{|c|c|}
\hline LOTEAMENTOS/BAIRROS & LEI E DATA DE APROVAÇÃO \\
\hline Bairro de Fátima ${ }^{80}$ & Década de 50 \\
\hline Bairro do Carmo & Lei $n^{\circ} 363 / 60$ de $28 / 06 / 60$ \\
\hline Bairro Ramos & Lei $n^{\circ} 504 / 68$ de $14 / 05 / 68$ \\
\hline Bairro Bom Jesus & Lei $\mathrm{n}^{0} 508 / 68$ de $18 / 06 / 68$ \\
\hline Expansão do Bairro Cantinho do Céu & Lei $\mathrm{n}^{\circ} 511 / 68$ de $11 / 07 / 68$ \\
\hline Expansão do Bairro do Carmo & Lei $\mathrm{n}^{\circ} 530 / 69$ de $04 / 08 / 69$ \\
\hline Bairro Clélia Bernardes & Lei $n^{0} 615 / 72$ de $04 / 07 / 72$ \\
\hline Expansão do Bairro Ramos & Lei $n^{\circ} 625 / 72$ de $04 / 07 / 72$ \\
\hline Loteamento próximo à Barrinha & Lei $n^{\circ} 627 / 72$ de $04 / 07 / 72$ \\
\hline Loteamento próximo à R. Gomes Barbosa & Lei $n^{\circ} 629 / 72$ de $04 / 07 / 72$ \\
\hline Condomínio horizontal Parque do Ipê & Lei $n^{\circ} 642 / 72$ de $05 / 12 / 72$ \\
\hline Expansão do Bairro Santo Antônio & Lei n ${ }^{\circ} 645 / 73$ de $29 / 01 / 73$ \\
\hline Expansão do Bairro de Fátima & Lei $^{\circ} 50 / 74$ de $09 / 05 / 74$ \\
\hline Prolongamento da rua Floriano Peixoto & Lei ${ }^{\circ} 55 / 74$ de $23 / 05 / 74$ \\
\hline Expansão do Bairro Santo Antônio & Lei ${ }^{\circ} 58 / 74$ de $23 / 05 / 74$ \\
\hline Expansão do Bairro Santo Antônio & Lei ${ }^{\circ} 67 / 74$ de $01 / 07 / 74$ \\
\hline Loteamento em Silvestre & Lei ${ }^{\circ} 81 / 74$ de $01 / 10 / 74$ \\
\hline Expansão do Bairro Nova Era & Lei ${ }^{\circ} 86 / 74$ de $23 / 10 / 74$ \\
\hline Bairro João Braz & Lei $n^{\circ} 108 / 75$ de $18 / 03 / 75$ \\
\hline Bairro Arduíno Bolívar (Amoras) & Lei $n^{\circ} 125 / 75$ de $28 / 04 / 75$ \\
\hline Condomínio Júlia Mollá & Lei $\mathrm{n}^{0} 158 / 75$ de $01 / 12 / 75$ \\
\hline Expansão do Bairro Santo Antônio & Lei $\mathrm{n}^{\circ} 159 / 75$ de $01 / 12 / 75$ \\
\hline Loteamento em Silvestre (Indumel) & Lei $\mathrm{n}^{\circ} 160 / 75$ de $01 / 12 / 75$ \\
\hline Nova expansão do Bairro de Fátima & Lei $n^{\circ} 197 / 76$ de $22 / 03 / 76$ \\
\hline Alameda Fábio Ribeiro Gomes & Lei $n^{\circ} 204 / 76$ de $22 / 09 / 76$ \\
\hline Bairro Santa Clara & Lei $n^{\circ} 241 / 77$ de $23 / 09 / 77$ \\
\hline Bairro J. K. & Lei $n^{\circ} 243 / 77$ de $11 / 10 / 77$ \\
\hline Bairro Nova Viçosa ${ }^{81}$ & Clandestino \\
\hline Bairro Inconfidência & $\begin{array}{l}\text { Aprovado pelo Exec. Municipal: } \\
26 / 11 / 79\end{array}$ \\
\hline
\end{tabular}

Fonte: Câmara Municipal de Viçosa.

Os loteamentos inseridos no quadrado foram realizados após a federalização da UFV. Fonte: Modificado de RIBEIRO FILHO, 1997, p. 129.

O processo de crescimento das ocupações irregulares em encostas e o modo como o problema foi - e ainda é - encarado pela municipalidade e população local é também determinante no entendimento do processo de segregação com a expansão da malha urbana. Ainda no início da década de 1970, o crescimento de favelas em parte das áreas centrais da cidade foi motivo de debates que geraram a lei $n^{\circ} 609$ de dezembro de 1971, que proibiu o "Prolongamento de Favelas" (RIBEIRO FILHO, 1997, p. 142) e buscou "proteger o coração da cidade" através da proibição da construção de "casebres" no centro (COELHO e CHRYSOSTOMO, 2015). Desta forma a lei buscou evitar uma maior 
favelização justificando que as construções precárias provocariam "má impressão" aos turistas, tendo em vista a proximidade do centro com ocupações como o "Morro do Rebenta Rabicho" (primeira denominação ao hoje bairro Sagrado Coração de Jesus) (COELHO e CHRYSOSTOMO, 2015). Algumas delas continuam como favelas e ainda hoje são discriminadas reiteradamente nas mídias da cidade, colocando-as como lócus de tráfico de drogas e violência ${ }^{75}$.

As ideias de uma espécie de "limpeza" da paisagem de cidade foram colocadas em prática pela municipalidade com o apoio das elites urbanas. Com a cidade ganhando cada vez mais visibilidade e importância regional, os cortiços, barracões, ocupações irregulares e construções precárias foram vistas como problemas estéticos que afetariam o mercado imobiliário da região central, cada vez mais valorizada (COELHO e CHRYSOSTOMO, 2015).

A questão da irregularidade, vale frisar, não era empecilho para a municipalidade quando se tratava de construções das classes mais ricas. Estudos como o de Dias (et al., 2014) também mostram que a irregularidade de lotes e construções em Viçosa acontece tanto nas áreas centrais quanto nas periferias, por diferentes motivos, sendo o fator da busca pela extração máxima de renda o principal nas irregularidades do centro.

Essa ganância por parte de loteadores e construtores se concretiza em afastamentos irregulares, taxas de ocupação acima do permitido, desobediências às legislações ambientais, o não cumprimento de contrapartidas à municipalidade, em reiteradas pressões para mudanças na legislação urbana, etc. Ribeiro Filho (1997, p. 161) estimou uma taxa de 93,66\% de construções irregulares em toda a cidade ${ }^{76}$ para 1996.

75 Como apresentado em: SANTOS, Rafaela. O papel do jornalismo impresso na construção do sujeito violento: análise das páginas policiais do jornal folha da mata. Trabalho de Conclusão de Curso (Graduação em Comunicação Social/Jornalismo), Departamento de Artes e Humanidades - UFV, Viçosa, 2013.

${ }_{76}$ Ribeiro Filho (1997) utilizou como fonte de dados os números de licenças construtivas emitidos a cada ano de 1983 a 1996, comparando-os com o número de ligações de água efetuadas a cada ano pela autarquia responsável pela distribuição de água no município, o SAAE-Viçosa. O índice varia pouco, permanecendo próximo dos $90 \%$ durante todo o período por ele analisado. 
Ou seja, pelo histórico das medidas regulatórias percebemos que elas objetivaram apenas um marketing político de pró-atividade dos gestores e legisladores ou a manutenção do status social, seja por políticas higienistas e classistas, seja por ordenamento estético de ruas e até mesmo de fachadas, como vimos. Contudo, têm-se na década de 1970 o agravamento das práticas de agentes da construção civil nos loteamentos e construções, inclusive com práticas populistas que deixam claras as relações entre o poder político e econômico que privilegiaram o setor da construção civil (Figura 12).

Figura 12: Vista do centro a partir de área próxima da favela "Rebenta Rabicho", na década de 1970

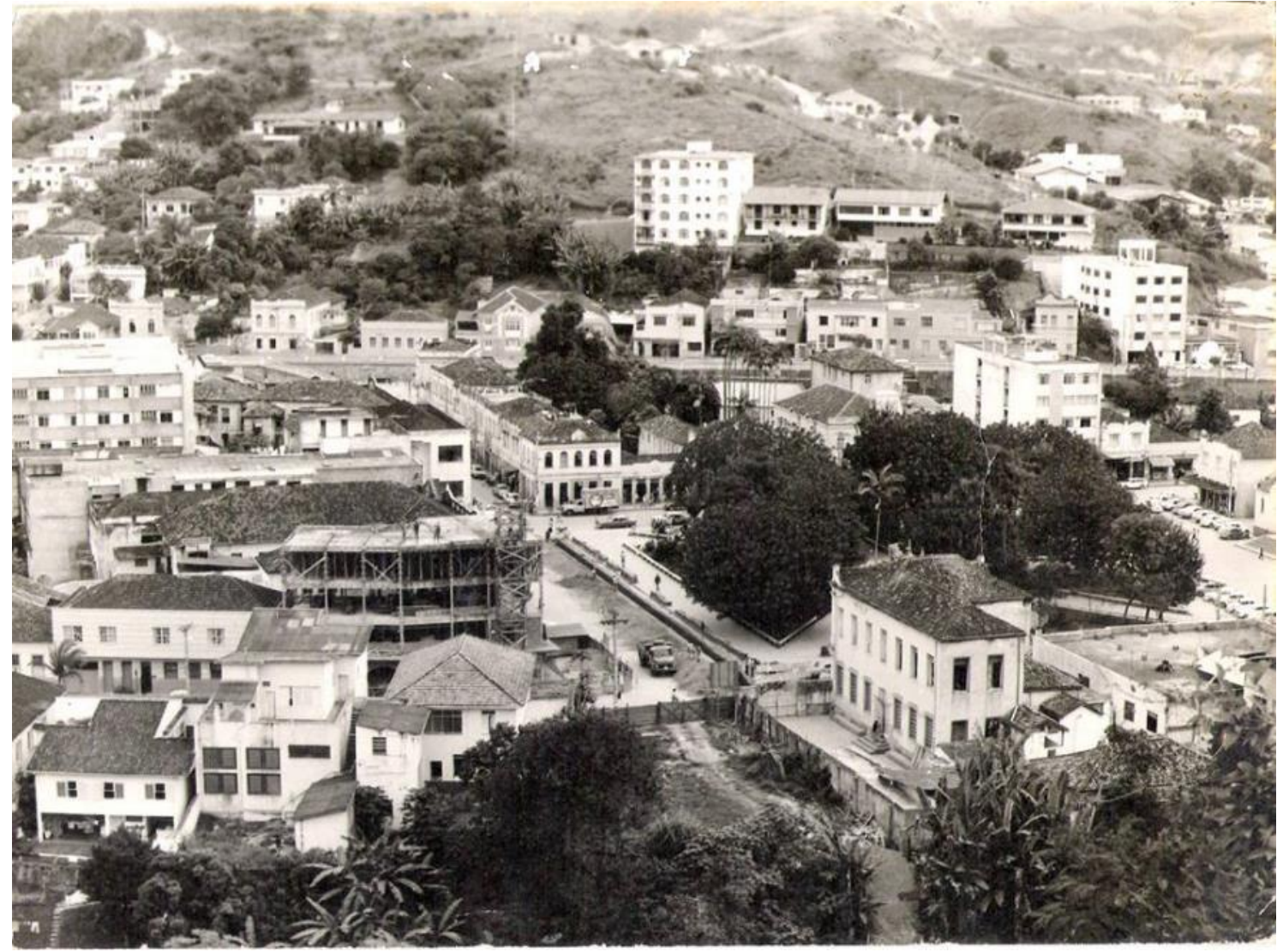

Fonte: Foto publicada no Museu Virtual de Viçosa (plataforma online colaborativa) Acesso em: 18 ago 2016.

Nessa época este setor já era o responsável por cerca de 16,9\% da População Economicamente Ativa urbana (RIBEIRO FILHO, 1997, p. 148) e, enquanto a UFV apresentava um rápido desenvolvimento, com construções e organização de seu espaço, a prefeitura municipal da cidade, em diferentes administrações, não acompanhou devidamente o crescimento da cidade, com 
pouca ou nenhuma atuação no sentido da organização da vida urbana, sobretudo nos bairros populares.

Dessa forma as administrações municipais abriram grandes brechas para que a tarefa da organização da vida urbana recaísse nas mãos de agentes particulares: construtoras; proprietários fundiários; e imobiliárias. Estes, obviamente, almejam primeiramente o lucro e, em muitos casos, desprezam os fatores ambientais e a qualidade de vida nos locais por eles 'ordenados'. Esses agentes agiram rápido de acordo com a oportunidade de expansão da cidade e contaram com a cumplicidade ou a omissão dos agentes políticos que, por sua vez, pertencem ao mesmo grupo social que os agentes imobiliários. Segundo COELHO e CHRYSOSTOMO (2015, p. 289):

Na maior parte dos casos, o crescimento imobiliário de Viçosa foi resultante da associação de diferentes capitais: o capital financeiro (bancos) e os capitais imobiliários e fundiários (construtoras, em especial, a Construtora e Incorporadora Chequer).

Maior exemplo do envolvimento entre política e empresas do ramo imobiliário na cidade está nas ações políticas e empresariais do Sr. Antônio Chequer. Ele foi três vezes vereador, presidiu a Câmara Municipal da cidade e foi, ainda, três vezes prefeito, nos mandatos de 1973-76, 1989-92 e em 1997, quando faleceu no primeiro ano de seu mandato. Além disso, atuou como empresário comandando a empresa da construção civil de Viçosa que é atualmente uma das maiores do ramo. Trabalhou com seus irmãos Elias e José Chequer, ambos também com vínculos políticos com a cidade. Conhecido como "o pai dos pobres" por muitos de seus admiradores, Antônio Chequer foi o responsável pelo loteamento de grande parte de Viçosa. Desde bairros hoje tidos como de classe média a bairros populares, sua atuação modificou a estrutura urbana da cidade no seu período de maior crescimento populacional.

A demanda por terrenos servidos de infraestrutura próximos ao centro aumentou muito. Porém os valores também cresceram, ocasionando a ocupação de lotes ou terras distantes do centro e, por consequência, distantes dos equipamentos e desprovidos de serviços urbanos básicos, como acesso aos sistemas de água e esgoto, ou até mesmo transporte urbano. Assim, as 
oportunidades para agentes imobiliários eram boas e o contexto político também. Antônio Chequer, então, decide aumentar sua atuação empresarial em loteamentos, e abre vias e bairros novos. Vendo a valorização ameaçada pela favelização e presença de sem-tetos, os agentes imobiliários concentram seus investimentos em terrenos situados na zona rural da cidade, visando a venda a preços baixos para uma população que não dispunha de verbas para pagamentos maiores.

Antônio Chequer, então, promove a compra de sítios e fazendas para a conversão destas terras rurais em terrenos urbanos, mesmo sem a disponibilidade de serviços básicos a alguns desses loteamentos. Um deles, e o mais icônico, é o bairro Nova Viçosa (Figura 13). O loteamento foi feito com o objetivo de, pelas palavras do próprio loteador, "impedir que as favelas da cidade crescessem" (SANTOS apud RIBEIRO FILHO, 1997, p. 129). As "favelas" que não poderiam crescer situavam-se muito próximas ao centro da cidade, como a ocupação do "Rebenta Rabicho" já mencionada.

Podemos observar pelo nome dado ao loteamento - posteriormente dado como bairro - que havia no local o depositário de esperanças para muitas famílias que necessitavam de um lote para darem início à suas vidas na cidade. Como os terrenos foram doados ou vendidos a preços muito baratos $\mathrm{e}$ proporcionaram o estabelecimento de famílias carentes na cidade (RIBEIRO FILHO, 1997; COELHO e CHRYSOSTOMO, 2015), este loteamento foi o principal responsável pela alcunha dada a Antônio Chequer como "o pai dos pobres". Estima-se que dos cerca de 4.000 lotes, um quarto destes tenham sido doados sem, contudo, os devidos documentos legais de posse ou o provimento das infraestruturas mínimas.

O referido loteamento foi realizado distante da malha urbana existente, e por trás de uma barreira geomorfológica que dificulta o acesso ao bairro ainda hoje, pois permanece espacialmente segregado da cidade (Ver Mapa de bairros, em anexo). Logo em seguida, devido às muitas carências do bairro, o local foi alvo de ações de filantropia, sobretudo ligadas à Igreja Católica local através da Madre Maria das Neves, freira carmelita que dirigia a principal escola particular 
da época ${ }^{77}$. O bairro é até hoje local estigmatizado pela violência e pobreza, apresentando os piores índices socioeconômicos da cidade, como o de renda per capita, que está em torno dos 384 reais (CRUZ, 2014).

Figura 13: Dia da "inauguração" do loteamento Nova Viçosa, em 1978

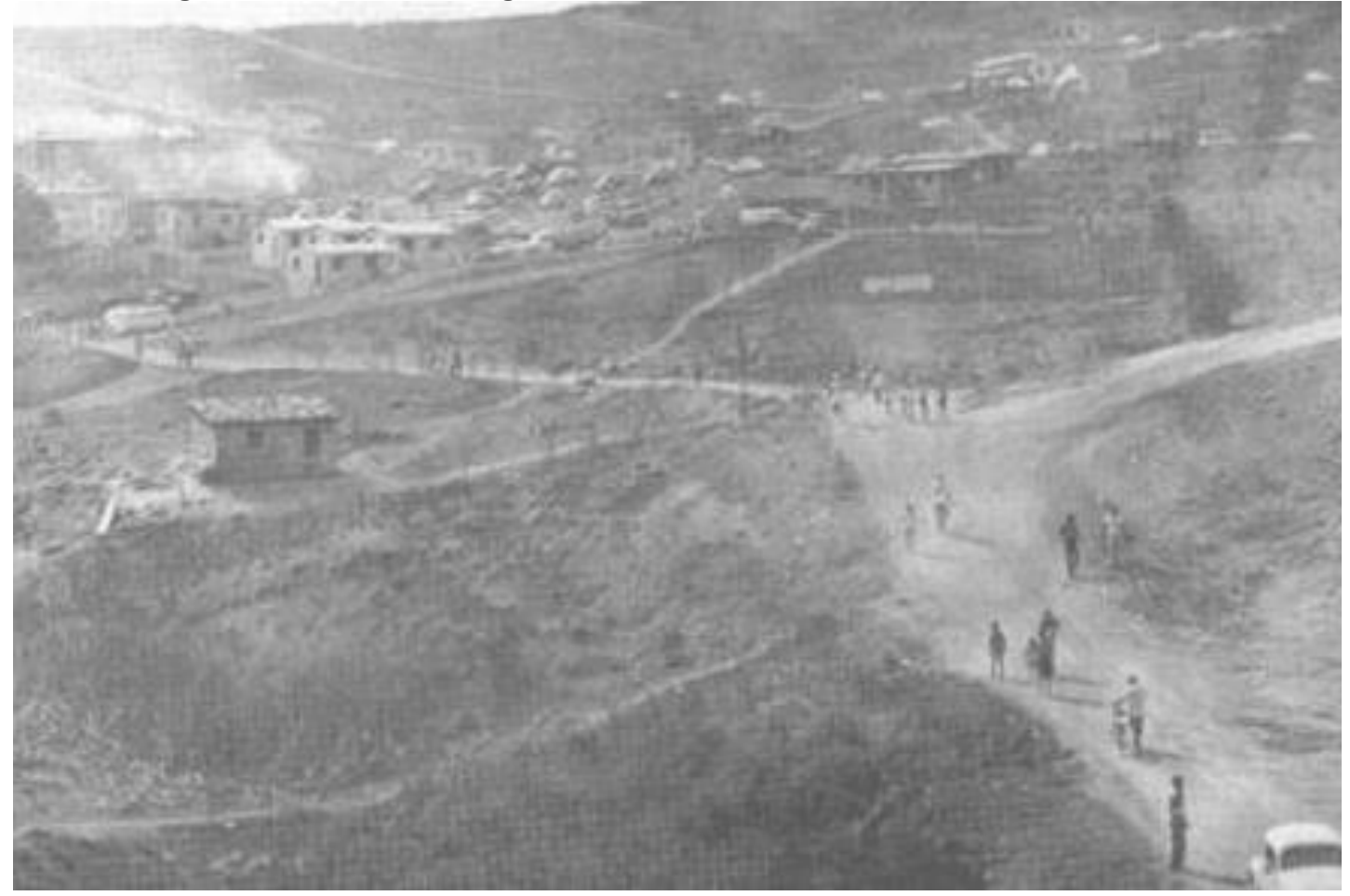

Fonte: <http://opassadocompassadodevicosa.blogspot.com.br/> Acesso em: 10 jun 2015.

Outros loteamentos que posteriormente se transformaram em bairros foram, segundo COELHO e CHRYSOSTOMO (2015): "Amoras, Betânia, Santo Antônio, Lourdes, Nova Viçosa, parte do Silvestre e Ramos." (p. 287). Além desses loteamentos, os dos bairros Clélia Bernardes, Prefeito João Braz e Santa Clara foram realizados ainda na década de 1970 pela família Chequer.

O processo de valorização imobiliária (que favoreceu alguns poucos proprietários), a estocagem de terras (o caso de Elias Chequer é ilustrativo já que obteve terrenos em Amoras que ficaram parados há onze anos) e os serviços e equipamentos concentrados nas áreas centrais, demonstram que a obra de alguns agentes foi apropriada de forma "seletiva e desigual". Desta forma, observamos que o movimento de expansão geográfica dos diferentes capitais levou a territorialização de várias áreas da cidade. (COELHO e CHRYSOSTOMO, 2015, p. 289)

77 Fonte: <http://opassadocompassadodevicosa.blogspot.com.br/> Acesso em: 18 ago 2016. 
Desta forma consolida-se a lógica de expulsão de famílias de baixa renda da área central, mantendo o objetivo de valorização das terras dessa área através do investimento em infraestrutura e da especulação de lotes vagos. Enquanto isso, por conta da venda a preços módicos de terrenos para as populações carentes, o poder político do empresário Antônio Chequer cresceu e, logo em seguida, foi eleito prefeito da cidade para seu primeiro mandato. Mesmo que a posse da terra ainda seja um problema do ponto de vista da legalidade nos bairros mais carentes loteados pelo empresário, o "mito" prevaleceu e com ele a influência política da família na cidade.

Posteriormente, algumas ações políticas de Antônio Chequer e de seus familiares foram responsáveis por mudanças na legislação de uso e ocupação do solo, proporcionando aos agentes imobiliários maior liberdade construtiva e, novamente, mudando a morfologia urbana de Viçosa. Temos, assim, no início da década de 1980, a mudança da legislação do Código de Obras do município. $\mathrm{Na}$ ocasião, houve uma tentativa da municipalidade de se fazer valer a legislação que vigorava sobre loteamentos e construções.

A situação de fiscalização da municipalidade sobre a produção do espaço urbano era tão evidentemente ineficiente (propositalmente ou não) que a imprensa local escreveu: "Se há uma determinação legal do município que se tem feito valer apenas no papel, esta é, sem dúvida, a que trata dos Código de Obras e de Posturas Municipais de Viçosa. Vários flagrantes de desrespeito a estes códigos (...) saltam aos olhos da população (...)" (JORNAL INTEGRAÇÃO apud RIBEIRO FILHO, 1997, p. 155). A partir de pressão do setor imobiliário sobre a prefeitura, a tentativa foi transformada em um "abrandamento" do referido Código, revogando dele as normativas mais restritivas e que mais eram desobedecidas pelo setor da construção civil na cidade. Um dos vereadores que apresentou as propostas de mudança da legislação foi Elias Chequer, "o maior empresário da construção civil da cidade" (RIBEIRO FILHO, 1997, p. 156). resultado, contudo, não foi uma maior obediência ao Código, mas a continuação de irregularidades construtivas por toda a malha urbana.

As ações perpetradas pelas famílias do setor imobiliário continuariam na década de 1990. Como nos mostra (RIBEIRO FILHO, 1997. p. 181): 
Ainda em 1991, foi aprovada nova lei de parcelamento do solo do município de Viçosa - lei n 783/91, de 27 de maio de 1991. Esta lei é originária de projeto de autoria do vereador José Chequer, irmão do prefeito da época - Antônio Chequer - e de um empresário da construção civil. Ela foi aprovada para ser uma lei complementar à lei federal no 6766/79, mas, na realidade, em vez de seguir as prescrições da lei maior ou determinar exigências maiores, ela impõe restrições menores do que as estabelecidas pela lei federal, que servem mais aos interesses daqueles empresários e da classe que representam do daqueles dos segmentos sociais de baixa renda.

Tem-se como exemplo na legislação municipal supracitada, de 1991, que deixa a cargo dos construtores e de decisões não padronizadas o respeito ou não à legislação federal. Como destaca Ribeiro Filho, isso acontece em dois pontos importantes das legislações:

Esses desencontros entre as duas leis podem ser verificados em pelo menos dois artigos. Enquanto a lei federal no 6766/79 proíbe não só o parcelamento do solo em terrenos com declividades iguais ou superiores a $30 \%$, mas também a edificação ao longo de uma faixa de 15 metros, contada a partir das margens de águas correntes e dormentes e das faixas de domínio de rodovias, ferrovias e dutos, denominada faixa non aedificandi, a lei municipal no 783/91 proíbe o parcelamento do solo somente em terrenos com declividades iguais ou superiores a $40 \%$, para os lotes que tenham frente mínima de 15 metros (art. 50, III).

Além disso, em relação à faixa non aedificandi, o poder público municipal substituiu a expressão, contida na lei no 6766/79, "será obrigatória a reserva de faixa non aedificand" por "poderá exigir a reserva de faixa non aedificandi", o que muda totalmente o sentido da lei. (RIBEIRO FILHO, 1997. p. 182)

Cabe ressaltar que não apenas em Viçosa, mas, como destacado por Maricato (2011a, p. 188), esse tipo de "parceria" entre poder público e mercado imobiliário não é raro no Brasil: "Ou seja, bem de acordo com a tradição nacional de aplicação da lei de acordo com as circunstâncias e o interesse dos donos do poder, aprova-se uma legislação ilegal". Dessa forma, podemos apontar para um poder público colonizado pelo empresariado local e suas práticas de tal forma que este setor da sociedade não apenas modifica a estrutura espacial e social com suas atividades regulares ligadas à ao mercado imobiliário, mas legisla e faz a gestão das fronteiras entre legalismos e ilegalidades no município; criam e administram o território e, não por acaso, eles conformam um oligopólio com relação ao acesso à terra urbanizada, como podemos observar no alto grau de 
concentração fundiária no qual quatro empreendedores individuais detinham $25 \%$ dos lotes vagos da cidade em 2003, dado revelado na pesquisa de Pinheiro (2004, p. 29).

Com o aquecimento da economia e intensa urbanização vivida pela cidade nos anos de 1980, os anos de 1990 recebem como herança um espaço urbano com o centro já adensado e a formação e consolidação de diversas ocupações em encostas. A escassez de espaços públicos na cidade faz com que a UFV passe a ser o principal local de lazer de grande parte dos moradores da região central, mesmo os provenientes de favelas e loteamentos irregulares (algo que permanece até hoje). A UFV tornou-se um parque urbano para a população.

A localização próxima da universidade é cada vez mais disputada e poucas empresas controlam o monopólio desse privilégio. Portanto, o processo de verticalização do centro iniciado timidamente na década de 1970 torna-se, vinte anos depois, o principal fator de mudança da paisagem urbana, adensando ainda mais o centro e provocando a piora na qualidade de vida. Esse fato é observado sobretudo em relação à mobilidade, pois a rede de ruas passa a apresentar congestionamentos e as calçadas deterioradas e estreitas representam dificuldades de locomoção no centro. Ou seja, problemas usualmente metropolitanos passam a fazer parte do cotidiano dos moradores de Viçosa, à época com pouco mais de 50 mil habitantes.

O avanço do mercado imobiliário nos anos de 1980 e 1990 passam a chamar a atenção de empresas de fora da cidade, que procuravam por campos de ampliação de mercado. Como salienta um corretor imobiliário em entrevista à Karine Paula (2013, p. 69): "No início (1990) os investidores eram pessoas daqui de Viçosa mesmo, e depois a notícia começa a se espalhar: 'investir em imóvel em Viçosa é um bom investimento'”. Dessa forma entram no mercado da cidade novas empreiteiras, como a ENCOL, uma das maiores empresas de construção para o mercado imobiliário da época no Brasil ${ }^{78}$. 0 poder público,

78 A empresa veio a pedir concordata em 1999, após escândalos de corrupção e estelionato e crescimento de sua dívida com bancos. O edifício inacabado da empresa em Viçosa foi comprado e terminado em meados dos anos 2000. 
ainda condescendente ou claramente direcionado, não foi empecilho para a verticalização e ocupação que avançou até mesmo sobre o principal curso d’água da cidade, o Ribeirão São Bartolomeu (Figura 14)

\section{Figura 14: Edifício Burle Marx II, em 2015}

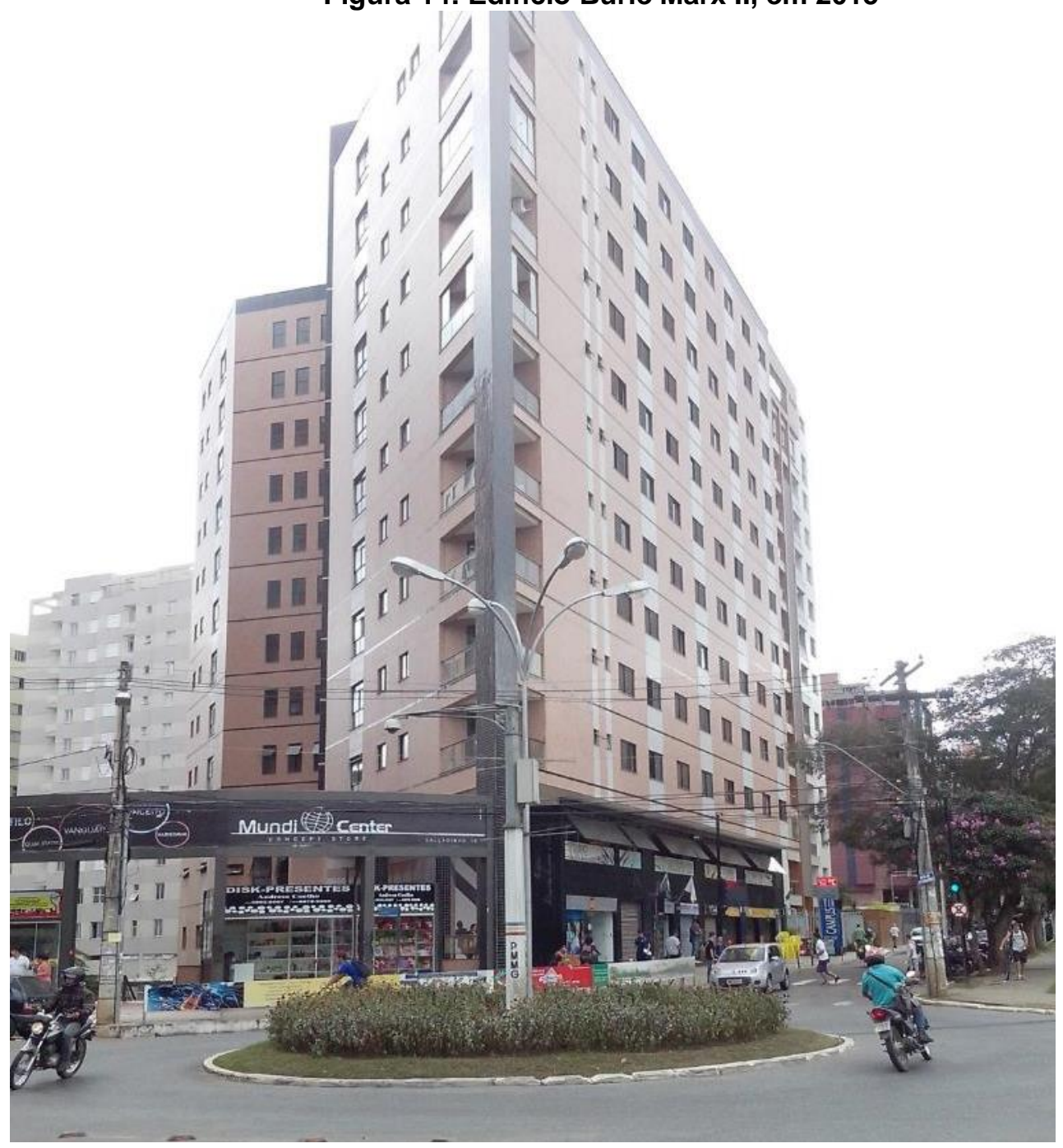

O Ribeirão São Bartolomeu foi canalizado nesse trecho após a grande enchente de 1947. 0 curso d'água passa por baixo da rotatória. À direita da rotatória está a entrada principal da UFV. Os edifícios Burle Marx I e II foram construídos um ao lado do outro, no final da década de 1990 e início dos anos 2000, respectivamente, ambos da Construtora Carvalho e Chequer. São chamados popularmente de "Carandiru", em alusão ao conhecido presídio paulista. Fonte: Arquivo do autor. 2015.

Já nos anos 2000 há um resgate e ampliação do processo de saída das elites urbanas do centro da cidade em direção às periferias bem estruturadas. $O$ mercado imobiliário passa a investir mais, então, na implantação de condomínios fechados. Ainda na década de 1970, Viçosa teve a implantação de seu primeiro condomínio fechado, o Parque do Ipê (1972). O empreendimento pode ter sido "inspirado" pela criação, anos antes, da Vila Gianetti dentro da UFV, um conjunto 
de casas construídas para abrigarem os professores convidados da Universidade de Purdue, dos EUA. O condomínio foi implantado com desenho baseado nas propostas norte-americanas de "clusters" e, devido ao alto rendimento dos professores que voltavam do exterior (segundo Ribeiro Filho, muito acima dos rendimentos dos professores e funcionários da cidade), virou sinônimo de status social morar naquela localidade. Assim, ocorreu a criação do condomínio Parque do Ipê e, posteriormente, do condomínio Acamari (1980), ambos voltados aos servidores da UFV de maior renda.

Dessa forma, criou-se na cidade um imaginário de status social fortemente ligado aos condomínios fechados, o que impulsionou a criação de outros empreendimentos do tipo nos anos 2000. Ao final da década, já havia sete condomínios fechados distribuídos pelas periferias da cidade com boa infraestrutura. Além dos dois citados, temos o Recanto da Serra, implantado nos anos de 1990 e, a partir dos anos 2000: Jardins do Vale (bairro que foi fechado a partir de 2000), Monte Verde, Caminho dos Lagos, Otávio Pacheco, Vereda do Bosque, Canto dos Sonhos, Vale das Acácias e Vale Verde (PORTUGAL, 2011; MARIA et al.; 2014).

\begin{abstract}
Além desses condomínios a cidade de Viçosa possui duas situações muito particulares quanto ao tipo de moradia em condomínios residenciais. Os casos do bairro Inconfidentes, Júlia Mollá, caracterizam-se como tentativas de se formar um condomínio fechado, porém, esses espaços não são fechados, ou seja, não possuem portaria que controla a entrada e saída de pessoas e não tem muro de divisas. Todavia são bairros de classe média alta. (PORTUGAL, 2011, p. 12)
\end{abstract}

Ao final dos anos 2000 têm-se um novo boom imobiliário, quando a UFV teve nova expansão significativa de cursos, a partir do programa do governo federal REUNI. Então, o mercado imobiliário volta a se dedicar com mais atenção ao centro e suas áreas próximas, visando o público estudantil (Figura 15).

Nessa época a cidade já contava também com outras instituições de ensino superior, o que ajudou a manter o mercado aquecido durante toda a década. São elas: a Faculdade de Viçosa (FDV), de 1999; a Escola de Ensino Superior de Viçosa (ESUV), de 2001; e a Universidade de Viçosa (UNIVIÇOSA), de 2005 e que posteriormente incorporou a ESUV. Somando-se os estudantes ingressantes de todas as instituições de ensino superior da cidade, temos um 
montante de 4174 mil novos alunos todos os anos só para os cursos de graduação (CARVALHO, 2014, p. 107).

Figura 15: Viçosa no início da década de 2010

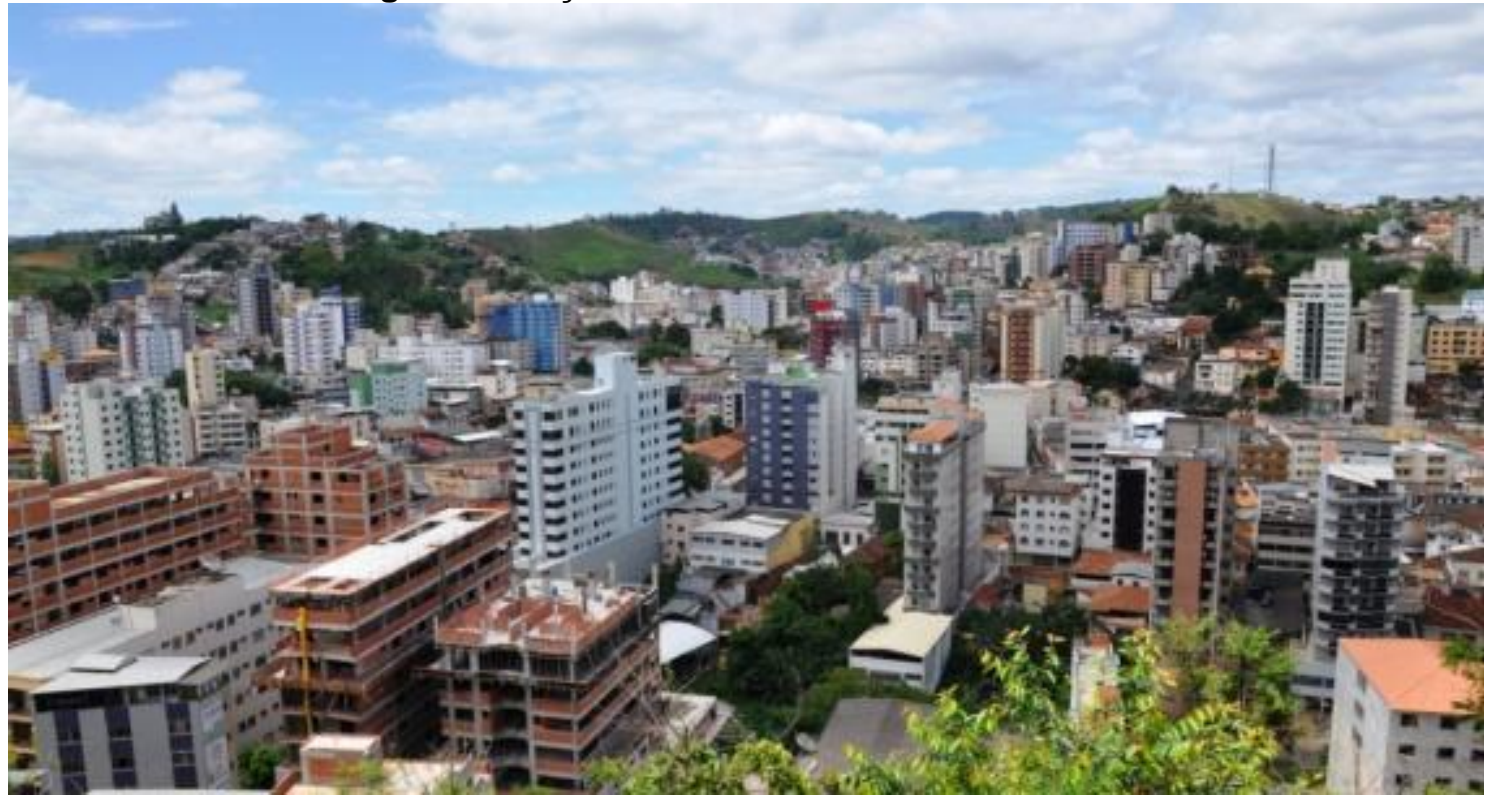

Observa-se na imagem alguns edifícios em construção. Todos eles, hoje, já finalizados. Ao fundo, vê-se algumas das ocupações de encostas de morros da cidade.

Fonte: < http://vicosanews.files.wordpress.com/2013/03/vic3a7osa-imagem-cc3b3pia.jpg > Acesso em: 19 ago 2016. 


\subsection{Contexto imobiliário}

Atualmente, o setor imobiliário da cidade vem rastreando novas terras para expansão horizontal da cidade, com reiteradas tentativas de municipalizar rodovias (que se tornaram urbanas, alterando afastamentos mínimos, gabaritos, etc.) e de transformar áreas rurais em urbanas, tendo em vista que a verticalização pela qual passou nos anos de 1990 e 2000 restringiram o número de lotes vazios no centro da cidade. Segundo estudo de Pinheiro (2004), em 2003 existiam 100 lotes vagos no centro. Como já citado, o mesmo estudo aponta para uma grande concentração fundiária na cidade: quase $25 \%$ de todos os lotes vagos na cidade pertenciam a quatro empreendedores imobiliários (PINHEIRO, 2004, p. 29).

No início da década de 2010, um lote ocupado por uma construção abandonada estava à venda destacando o fato de ser "o último terreno do centro", na Rua Milton Bandeira. O edifício que tomou o lugar da construção abandonada já teve sua obra concluída. Como já mencionado, o Programa Federal REUNI provocou uma nova onda de construções no Centro da cidade e, portanto, os terrenos nessa área estão ainda mais escassos.

O tipo de gestão urbana perpetrado por parte da prefeitura em diferentes mandatos do executivo fez com que os problemas territoriais aumentassem, assim como o problema da qualidade de vida que deve ser o objetivo das medidas legislativas e das práticas urbanísticas. Como consequência dessa gestão "diferencial" de territórios e de práticas irregulares, podemos observar na cidade o adensamento territorial do centro e de bairros centrais, a ponto de causar problemas na disponibilidade de serviços; e também a segregação socioespacial e a baixa qualidade de vida nos bairros populares e periféricos, onde faltam, sobretudo áreas de lazer e cultura (Mapa das Principais áreas públicas de lazer).

A vida urbana de Viçosa foi altamente impactada com a criação da UFV e suas ampliações. Observando as características econômicas, sociais e urbanas (cotidiano e físico-territorial) anteriores à federalização da Universidade e comparando-as com esses mesmos aspectos poucas décadas depois, podemos 
considerar que a UFV foi o principal elemento que estimulou a produção do espaço e a construção da vida urbana.

Em uma análise formal do espaço urbano da cidade, temos, de um lado, "periferias" espacialmente e/ou socialmente segregadas (próximas ou distantes da região central) e desabastecidas de serviços públicos, com habitações precárias ocupando encostas e margens dos cursos d'água (Figura 16); de outro, observamos um centro com oferta de serviços, mas extremamente adensado e sem qualidade físico-territorial, com graves problemas que são vistos, geralmente, em grades centros urbanos:

A qualidade de vida típica das cidades do interior mineiro foi se perdendo rapidamente com o aparecimento de uma série de problemas típicos das metrópoles brasileiras: poluição de seus córregos, engarrafamentos, violência urbana, áreas faveladas e acentuado processo de verticalização das suas edificações em determinadas áreas da cidade, ocasionando densificação excessiva ao se comparar com a infraestrutura e serviços urbanos disponíveis. (STEPHAN e RIBEIRO FILHO apud PORTUGAL, 2011. s/ p)

Podemos observar a extensão das áreas em situação urbana precária nos estudos realizados em 2012 para a elaboração de um Plano Local de Habitação de Interesse Social, o PLHIS ${ }^{79}$. Para a observação do mesmo mapa deve-se atentar para a área da UFV, que compõe grande parte da porção urbanisticamente "não precária" da cidade. Cabe ressaltar também que existem áreas pertencentes a bairros de classe média e média alta, mas que, mesmo assim, não apresentam elementos urbanísticos de forma satisfatória, segundo os arquitetos responsáveis pela elaboração do mapa.

Os bairros populares permanecem, em grande parte, segregados, com construções ilegais e pobremente servidas, o que só aumenta a sensação de distanciamento e segregação entre os cidadãos. Estas ocupações (hoje bairros) de populações de menor renda são utilizados como âncora para a narrativa do medo, o que justifica parte do intenso processo de auto-segregação das

79 Optamos por apresentar o mapa no texto, pois, mesmo que a resolução da imagem não permita uma análise detalhada, o propósito é a visualização da proporção das manchas indicativas de assentamentos de qualidade urbana precárias da cidade com relação às áreas "não precárias". 
camadas mais abastadas visto nos últimos anos. Ainda segundo Portugal (2011), além dos condomínios residenciais fechados há "(...) loteamentos que fatalmente se transformarão nessa tipologia" (2011. s/ p). São locais visados por camadas das classes média e média alta da cidade, que procuram fugir dos transtornos encontrados no centro. Condomínios fechados, verticais e horizontais, multiplicaram-se e atualmente ocupam áreas nas periferias, muitas vezes dentro áreas de preservação ambiental e/ou se apropriando de vias originalmente públicas, em evidentes casos de privatização do espaço público.

Figura 16: Mapa de assentamentos precários de Viçosa (2012).

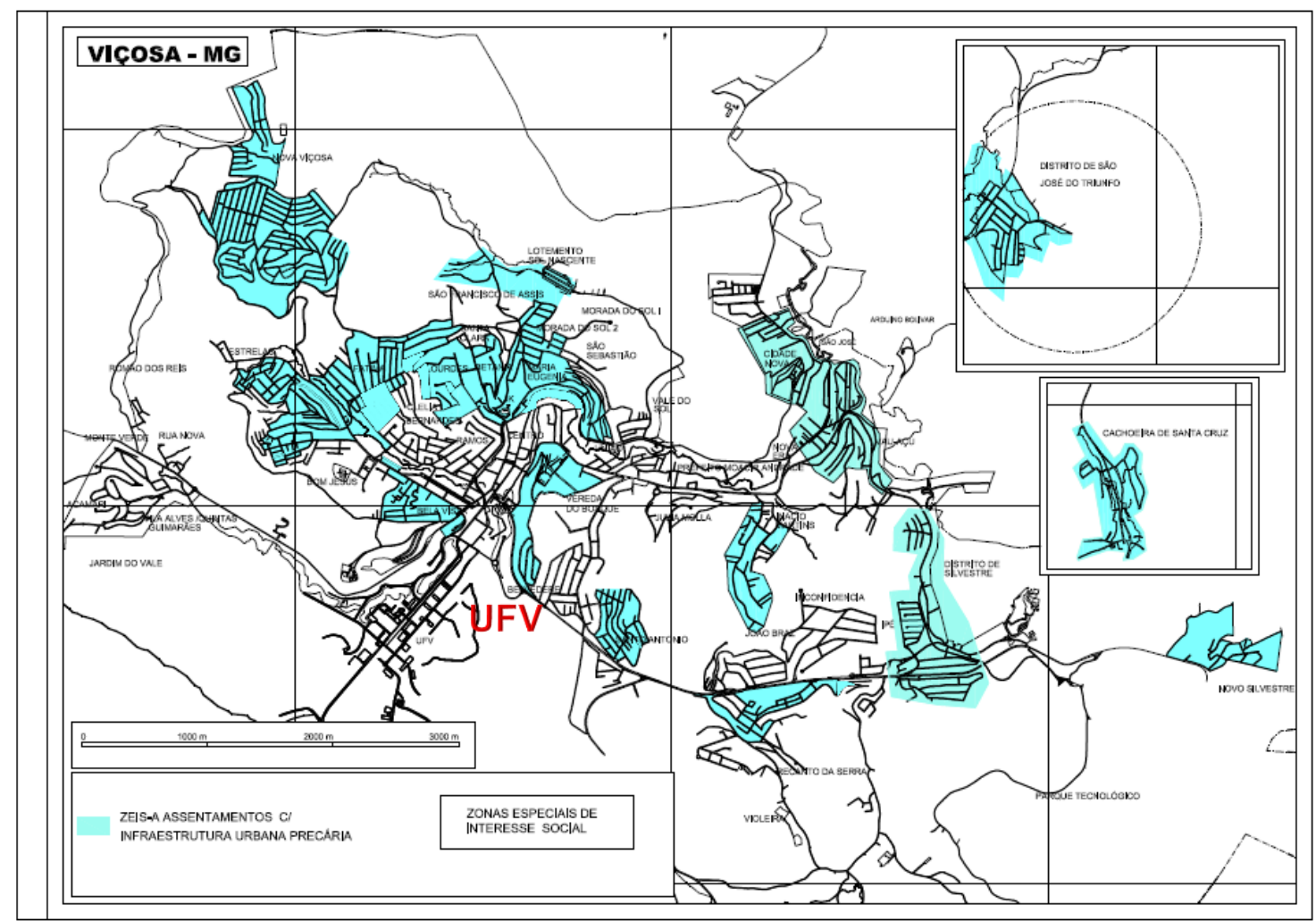

Autor: CRB arquitetos, modificado pelo autor.

O discurso higienista pode ser observado também em ações da prefeitura como o incremento no aparato de vigilância no centro da cidade e também no fechamento de espaços cobertos que eram utilizados por moradores de rua, como no caso da reforma realizada na Estação Cultural da cidade, onde painéis de vidro foram colocados para fechar parte da plataforma dessa antiga estação de trem, visando manter também uma boa imagem do patrimônio histórico edificado. 
Cabe ressaltar que Viçosa é "vendida" todo ano através da UFV, com o seu marketing institucional e poder atrativo de pólo educacional. A lógica imobiliária de Viçosa, no entanto, não é a do planejamento estratégico visando proporcionar um terreno fértil para a reprodução do capital de maneira constante. Não se visa à qualidade dos empreendimentos, pois estes não são ocupados pela parte superior da cadeia econômica viçosense. As elites urbanas da cidade, a exemplo do movimento de fuga dos grandes centros urbanos descrita por Caldeira (2000), passaram a ocupar as periferias dotadas de amenidades (Figura 17) e com acesso rápido aos locais de trabalho, como a UFV.

Figura 17: Entrada e guarita do Bairro Inconfidentes

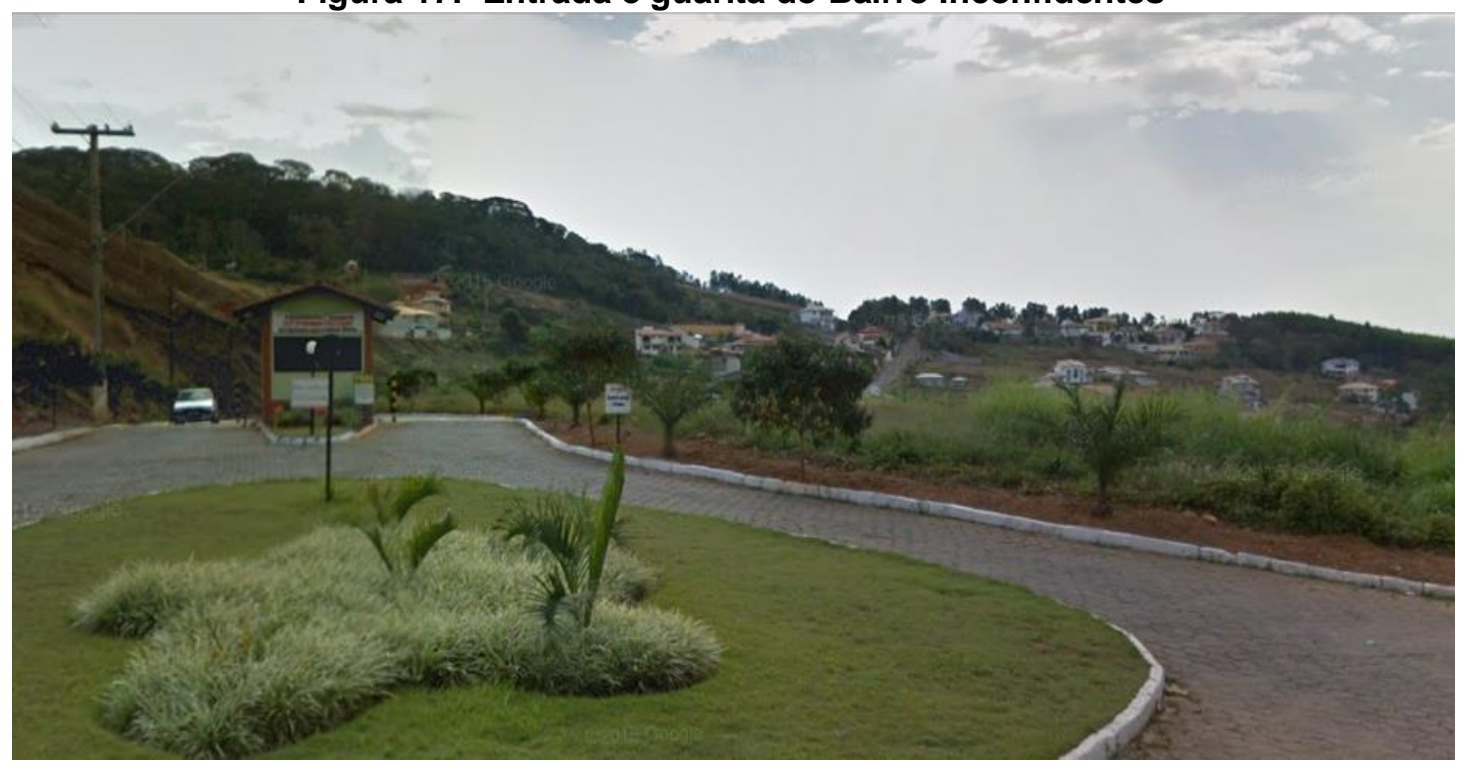

A Av. dos Inconfidentes conta com uma portaria em seu acesso instalada pelos moradores locais. A via é, contudo, pública. Há na portaria uma placa solicitando a gentileza dos visitantes se identificarem antes de acessarem o local. Nota-se que não há cancela na portaria.

Fonte: Google Street View - Maps.

Acesso em: 19 ago 2016.

Assim, percebe-se que o ramo da construção civil não impõe limites a sustentabilidade de seus negócios, obedecendo à lógica predatória nos moldes do extrativismo mineral. A especulação imobiliária funciona como em outras cidades: faz-se um banco de terras em localizações que em breve se tornarão raridade, pois a terra urbanizada e bem localizada está cada vez mais escassa e mais cara. Há também a estratégia da diferenciação social, reforçada pela imprensa local que amplia a sensação de insegurança da região central, buscando levar a classe média alta a seguir o movimento das elites locais em 
condomínios periféricos, enquanto a classe média disputa os espaços restantes do centro.

Desse modo, ocupando as áreas de melhor localização, as elites urbanas exercem o controle sobre o tempo de deslocamento, assim como descreve Villaça (2015), guardadas as devidas proporções, bem como o controle da melhor porção da infraestrutura da cidade. Contudo, apesar do movimento descrito, como o centro ainda é uma das áreas mais próximas à UFV e de melhor infraestrutura, a renda per capita continua alta, sendo a segunda maior do município segundo dados de 2014 (CRUZ, p. 53), perdendo apenas para o condomínio fechado Acamari80.

A questão do patrimônio cultural edificado é outro elemento que está sob ataque dos agentes imobiliários, tendo em vista a escassez de terrenos vagos na região central e a continuação do aumento da população e dos deslocamentos sociais no interior da cidade. Isso faz o mercado voltar suas atenções para as edificações menores e mais antigas que são, em alguns casos, de valor histórico e cultural para a cidade. Essas edificações são compradas e logo demolidas com o aval do Conselho Municipal de Patrimônio, pois apenas o terreno interessa. Como a cidade ainda está em crescimento, a demanda por terrenos no centro e proximidades é grande, e a lógica imobiliária preza pelo aproveitamento máximo destes, inchando ainda mais a região central. A velocidade com que os empreendimentos imobiliários são realizados não é acompanhada pela legislação e pela fiscalização local, e a memória da cidade vai se perdendo.

A ação dos agentes imobiliários (setor sob o domínio de poucas famílias, mesmo que atualmente um pouco mais diversificado) na esfera política da cidade é até hoje muito clara. São eles os principais financiadores das campanhas políticas tanto para obter apoio da Prefeitura quanto da Câmara dos Vereadores e, em muitos casos, são eles mesmos os governantes e legisladores, como apontado por Ribeiro Filho (1997). Como afirmou Schvarsberg (2012, s/p), "Basta checar as tabelas de contribuições de campanhas dos principais

80 Rendas de 1638 reais no Centro e 1755 no Acamari. 
candidatos" para entender a influência dessas empresas na condução da urbanização das cidades.

No pleito de 2012, o candidato a prefeito Dr. Celito Francisco Sari foi eleito tendo $23 \%$ da arrecadação de sua campanha por doações provenientes de alguma imobiliária, construtora, ou membro da família proprietária deste tipo de empresa $^{81}$. Na ocasião do falecimento do Dr. Celito Sari, em setembro de 2014 , quem assumiu foi seu vice, Ângelo Chequer, o filho mais novo do ex-prefeito Antônio Chequer e, portanto, ligado à família proprietária de imobiliária, construtora e incorporadora em Viçosa.

Para o pleito de 2016, Ângelo Chequer foi eleito prefeito tendo como vice o empresário Arnaldo Andrade, sócio e dono de empresas do ramo imobiliário. As doações à campanha realizadas por empresários e familiares de empresários desse seguimento foram responsáveis, na ocasião, por quase $80 \%$ das receitas de campanha ${ }^{82}$, a maior parte advinda dos próprios candidatos.

Dessa forma, o setor imobiliário pressiona o poder público para a criação de novos loteamentos nas periferias com boa estrutura urbana. As ações políticas do setor imobiliário chegaram ao extremo no final de 2012 , quando foi proposta a urbanização de uma grande área rural da cidade (conhecida como Paraíso) onde estão situadas importantes nascentes do Ribeirão São Bartolomeu, principal curso d'água para o abastecimento urbano. A proposta não continha um projeto de preservação do ribeirão, o que seria proposto posteriormente à legislação que mudaria o zoneamento da região, segundo os representantes da prefeitura. Ou seja, o projeto de preservação seria elaborado durante a movimentação do mercado imobiliário, o que, de acordo com o histórico legislativo da cidade, não nos permite confiar em sua realização. A tentativa da prefeitura de tornar urbana a área rural do Paraíso foi repelida

81

Dados

em:

$<$ http://inter01.tse.jus.br/spceweb.consulta.receitasdespesas2012/resumoReceitasByCandidato. action> Acesso em: 07 ago 2017.

${ }_{82}$ Quase $50 \%$ doados pelo próprio candidato a prefeito e outros $30 \%$ doados pelo candidato a vice, restando outras 3 doações não realizadas pelos fundos dos partidos. A maior delas por um familiar dono de 5 empresas do ramo imobiliário atuantes em Viçosa. Dados em: <http://divulgacandcontas.tse.jus.br/divulga/\#/candidato/2016/2/54275/130000018838/integra/re ceitas> Acessado em: 07 ago 2017. 
quando a população do lugar e demais cidadãos viçosenses pressionaram o poder legislativo e o executivo da cidade no sentido da preservação da área.

Ainda sobre a questão ambiental, a busca pela exploração máxima da renda da terra ocasionou uma intensa verticalização da região central com a ocupação quase perimetral dos terrenos, o que ocasiona todo o tipo de manobra para que o centro da cidade seja ocupado, até mesmo a desobediência às leis federais de proteção ao meio ambiente. Dessa forma, muitos prédios são construídos em encostas ou margens dos cursos d'água, como já apontado. Nesse último caso, em particular, os promotores imobiliários (Construtora Carvalho e Chequer) do empreendimento conseguiram a aprovação da construção de seu condomínio composto por dois prédios na área mais valorizada da cidade sobre o principal curso d'água do município. A construção se deu graças a uma contrapartida da construtora para a municipalidade, que seria uma praça pública entre os dois prédios. A empresa se aproveitou do espaço para colocar, no local, pequenas lojas além de banners publicitários.

Na região central, bares e restaurantes utlizam os espaços das calçadas para atenderem seus clientes (mesmo nas calçadas estreitas e sem recuo das edificações), o que configura novamente uma sobreposição de usos do privado sobre o público. No entanto, cabe ressaltar que esse tipo de uso configura a vitalidade do centro da cidade nos períodos noturnos e finais de semana, quando as calçadas e ruas chegam a ficar tomadas pelo público jovem.

Como foi possível observar, a urbanização realizada na cidade de Viçosa ocasionou problemas sociais e espaciais de ordens diversas. A relação dos viçosenses com o espaço público é conflituosa. A relação entre a municipalidade e os agentes imobiliários tem como resultado um espaço público diminuto e sem qualidade. As calçadas são, via de regra, estreitas e mal pavimentadas, mesmo no centro ou em bairros de classe média alta. Na região central há uma série de obstáculos nas calçadas colocados por comerciantes, além de postes e lixeiras que atrapalham a circulação. As ruas, eixos estruturantes de uma vida urbana, 
apresentam problemas de pavimentação e congestionamentos desproporcionais ao tamanho da cidade ${ }^{83}$.

Embora não tenha espaços de lazer adequados, a municipalidade é promotora, apoiadora e/ou gerente de parte das atividades culturais e artísticas desenvolvidas na cidade. Há diversas manifestações culturais, sobretudo religiosas, que agregam a população em um ambiente democrático, tendo em vista o caráter popular das manifestações. Nesses casos, a vida urbana toma ares de multiplicidade quando há participação de diferentes grupos sociais. Assim: "Essa diversidade de pessoas, com diferentes tipos de educação e 'status' sócio-econômico, interagindo com a população local de raízes tradicionalistas, formou um complexo humano heterogêneo" (PANIAGO apud PORTUGAL, 2011. s/ p). Existem ainda outras formas de sociabilidade promovidas por eventos e espaços culturais. É necessário destacar, porém, que grande parte das opções de cultura e lazer não é gratuita e acontece na região central. Ou seja, as oportunidades de encontro espontâneo entre diferentes classes são pontuais, pois estão condicionadas à realização de eventos comemorativos.

A UFV, novamente, está ligada de diversas maneiras à maior parte das atividades do gênero. Isso ocorre, principalmente, pela UFV ter à sua disposição o material, espaço e financiamento que podem ser direcionados às atividades. Dessa forma, observamos que, mesmo com certa variedade e disponibilidade de espaços e eventos artístico-culturais, estes eventos não atingem toda a comunidade viçosense. As iniciativas dos dois principais promotores culturais, a UFV e a Prefeitura Municipal, são insuficientes. Emergem, então, na cidade, iniciativas não assistidas de vivência em cultura. Há a atuação de pessoas e grupos independentes no desenvolvimento artístico-cultural da cidade. Porém, em sua maioria, de caráter não gratuito.

A escala da cidade (Figura 18) permite que parte da população segregada ainda esteja ao alcance das áreas centrais onde há disponibilidade de lazer e cultura, como a UFV. A escala da cidade modifica a perspectiva sobre as 
relações sociais. O tecido urbano e as populações periféricas não deixam de ser segregadas espacialmente e, em grande medida, socialmente, porém, parte dessas populações têm acesso ao centro e seus serviços. Bairros populares como os citados nesse estudo, excetuando-se alguns, têm sua vida urbana nos momentos de ócio atrelada à região central, sobretudo à UFV, onde o uso público de qualidade permite um uso voltado ao lazer e ao esporte.

Figura 18: Partes da UFV, do centro e das periferias de Viçosa em 2015

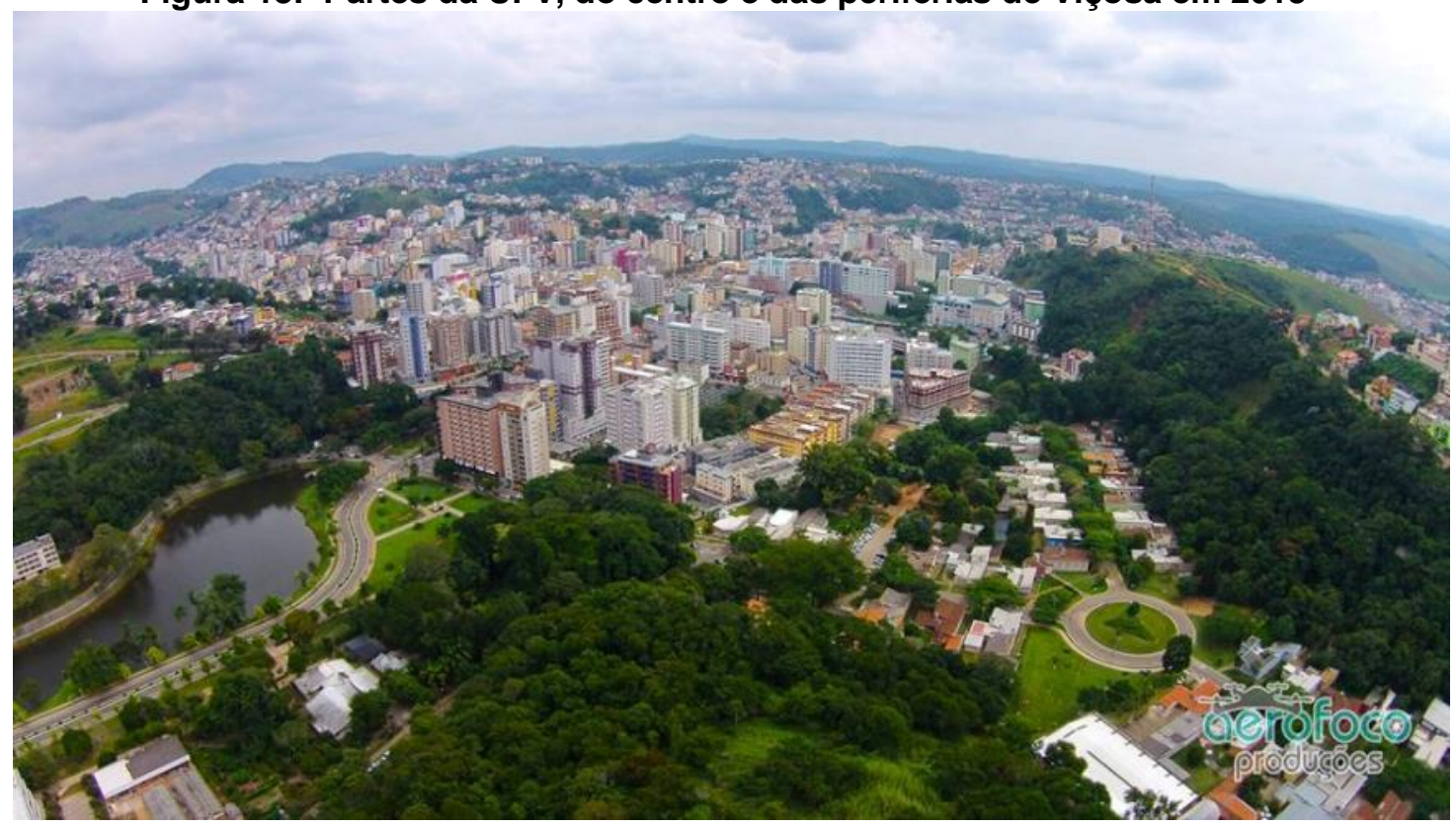

Abaixo, a entrada da UFV e a Vila Gianetti (atualmente não residencial). Ao centro e fundo, região central e bairros populares de Viçosa.

Fonte: <http://italostephanarquiteto.blogspot.com.br/2015/10/vista-assim-do-alto.html> Acesso em: 18 ago 2016.

Observamos diferentes problemas relativos às possibilidades de sociabilidades e apropriações coletivas dos espaços públicos, seja no cotidiano ou em eventos culturais e artísticos. Os principais problemas que impedem os encontros e trocas desejáveis nos espaços públicos são a mobilidade urbana e as limitações financeiras de grande parte dos moradores da periferia. Devido à morfologia acidentada do seu sítio, à configuração da malha urbana e aos altos preços estabelecidos para o transporte público, as pessoas que não vivem na região central encontram dificuldade no deslocamento até as áreas onde há espaços com infraestrutura, que abrigam a maior parte dos eventos da cidade. 
Mesmo tendo uma população de cidade pequena, com distâncias lineares que podem ser consideradas curtas entre moradia, trabalho e lazer, o histórico de produção de espaços segregados, bem como a falta de qualidade e disponibilidade de espaços públicos de lazer e encontro, confere à vida urbana um quadro de segregação que é, como veremos no próximo capítulo, reafirmado pela política habitacional do PMCMV. A implantação do MCMV segue a mesma lógica de loteamentos populares presentes na história da cidade, implantados em áreas de expansão da malha urbana, com barreiras geográficas que dificultam o acesso ao restante da cidade e ampliando o contingente de terras disponíveis para novas construções.

Conclui-se, portanto, que, por meio das ações das administrações municipais e dos agentes imobiliários da cidade a urbanização de Viçosa deu-se de maneira a explorar a renda sobre a terra urbana através da diferenciação de investimentos nas áreas já urbanizadas em relação às áreas recém-loteadas, gerando segregação socioespacial, usada como forma de atender diferentes demandas por terra e habitação, valorizando as terras das áreas centrais e promovendo certo controle social através do acesso às terras periféricas a preços mais baixos.

\subsection{O Minha Casa Minha Vida em Viçosa}

No mesmo ano em que o Governo Federal (segunda gestão Lula 20072010) anunciou o lançamento do Programa Minha Casa Minha Vida ${ }^{84}$, o então prefeito de Viçosa, Raimundo Nonato Cardoso (2005-201085), reuniu-se com a representante regional da Caixa Econômica Federal para resolverem as questões necessárias para a implantação do PMCMV na cidade. Na ocasião já havia a indicação do local escolhido para receber o primeiro empreendimento do programa. Segundo o prefeito, o bairro mais próximo carecia ainda de infraestrutura urbana e, com a implantação do MCMV numa área posterior a este

\footnotetext{
$84 \quad$ Lei $11.977,2009$.

85 Teve o segundo mandato interrompido por cassação da chapa junto ainda no início de
} 2010. 
bairro, a municipalidade aproveitaria a oportunidade para ampliar sua rede de serviços. Posteriormente, no estudo realizado a pedido da Prefeitura Municipal de Viçosa (PMV) consta que a escolha do terreno se deu por sua proximidade com a malha urbana, pela facilidade de implementação na localidade e por dispor de espaço para a implantação de empreendimentos semelhantes.

Apesar de constar nos documentos cadastrais do IPLAM (Instituto de Planejamento e Meio Ambiente do Município) como área urbana (SILVA, ANDRADE; 2014), a localidade escolhida para receber os dois conjuntos do PMCMV apresentava características rurais. Na época do início da construção do conjunto, havia na região residências com características rurais e dois bares. Os dois conjuntos estudados foram implantados próximos ao bairro Santa Clara, que ocupa as encostas e topo de um morro. Os conjuntos foram implantados na parte baixa da outra encosta deste mesmo morro, configurando-o como uma barreira geográfica (Figura 19).

Figura 19: Imagem de satélite destacando barreira geográfica entre a malha urbana 0 os conjuntos

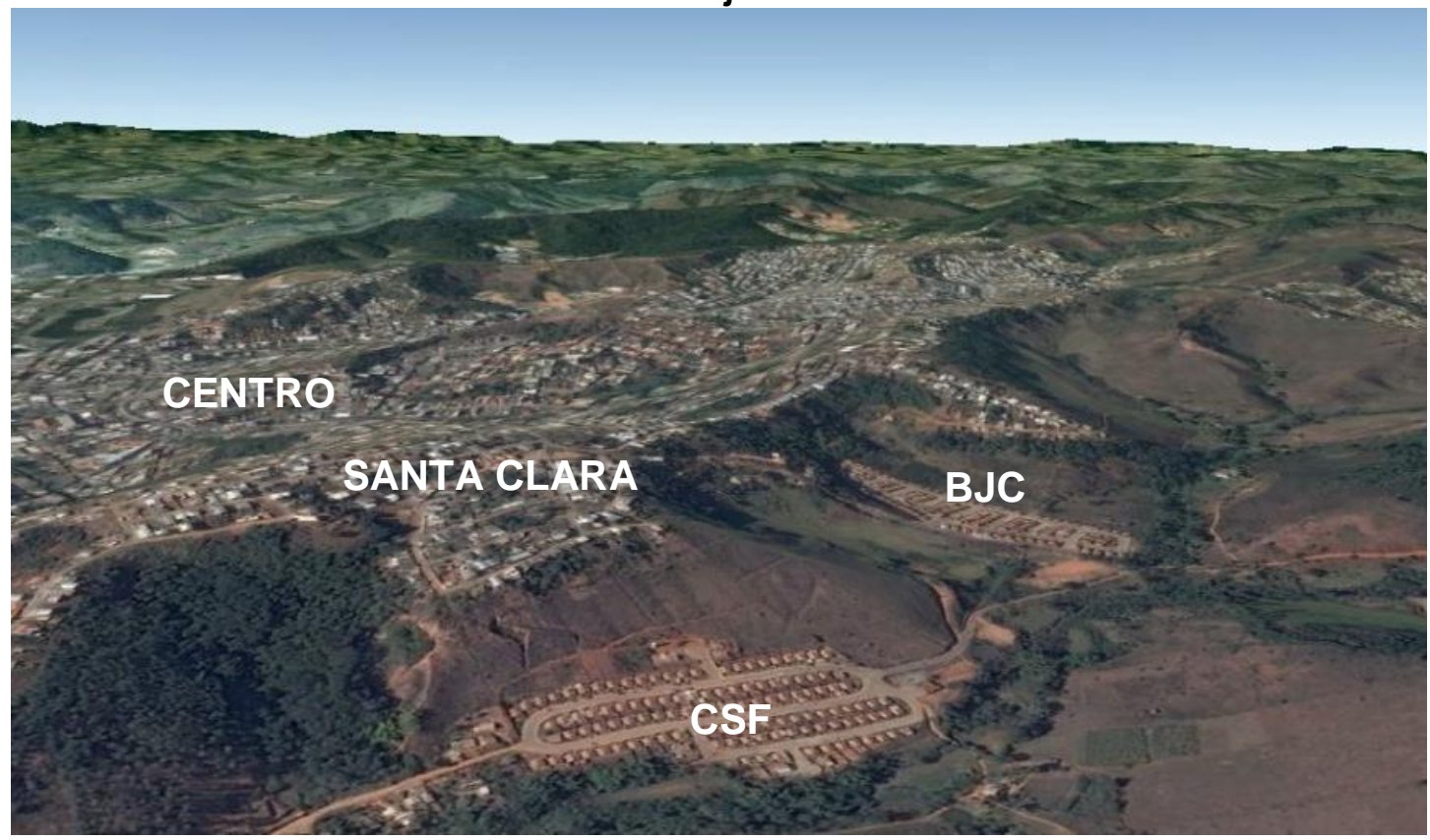

Abaixo, os dois conjuntos da tipologia de casas do PMCMV para a Faixa 1 em Viçosa. Fonte: Montagem do autor a partir de imagem do Google Earth Acesso em: 18 ago 2016.

O Bairro Santa Clara possui uma configuração territorial mista em relação às classes sociais de seus residentes, assim como em outros bairros da cidade próximos ao Centro, devido ao crescimento desordenado. Segundo Portugal é “(...) interessante notar que os bairros que se limitam com o centro da cidade 
possuem constituições mistas entre as distintas classes sociais (...)" (2011. s/ p). Porém, a "mistura" se dá apenas de maneira formal e em dados numéricos, pois os próprios moradores reconhecem a existência de três subpartes do bairro. A diferenciação por classe dentro do bairro - que não chega a ser uma regra depende da localização da moradia: na parte baixa, mais próxima do centro e, logicamente, dos equipamentos urbanos; ou na parte alta, mais distante do centro, com moradias em terrenos de grande declividade. Dessa forma há: um "Baixo Santa Clara", composto por famílias de classe média; um "Alto Santa Clara" composto, majoritariamente, por famílias de baixa renda; e um Santa Clara acompanhado do ponto de referência conhecido como "Praça da Pedra" que, apesar de estar na parte alta, apresenta uma população de classe média alta, com a tipologia predominante de sobrados unifamiliares.

O Alto Santa Clara, porção mais periférica do bairro e, por isso, mais próxima dos conjuntos habitacionais aqui estudados, apresenta, juntamente aos bairros Nova Viçosa e Fundão, os piores índices do município relativos à situação habitacional de seus moradores. Essa porção, junto com outras porções de bairros próximos ${ }^{86}$, tem uma média de 3,63 pessoas por domicílio, com um índice de $12 \%$ das residências abrigando seis pessoas ou mais, o mais alto de Viçosa (CRUZ, 2014, p. 46). Essa área é a que detém uma das menores rendas per capita do município, de aproximadamente 577 reais (CRUZ, 2014, p. 46). Outros índices negativos como o de desemprego, de vulnerabilidade familiar, analfabetismo e etc. também apresentam números altos para o Alto Santa Clara e imediações, o que reforça a caracterização da área como uma das que enfrenta maiores problemas no município.

A atenção dada aqui a uma breve caracterização do Alto Santa Clara e suas imediações se deve ao fato de que estas áreas correspondem aos últimos locais de habitação de uma parte dos moradores dos conjuntos, somando quase 25\% dos moradores (GUIMARÃES, 2013). Alguns deles advindos da ocupação de um conjunto de pequenos prédios abandonados, chamados pela comunidade de "predinhos". Ali, diferentes famílias dividiam unidades de habitação em

\footnotetext{
$86 \quad$ Pela metodologia adotada pelo referido documento, o Alto Santa Clara foi colocado juntamente com porções de outros bairros próximos, por apresentarem configurações socioeconômicas semelhantes, o que acreditamos não gerar prejuízo nas informações.
} 
condições precárias de conservação, com água e luz improvisados e de fornecimento inconstante ${ }^{87}$.

O primeiro conjunto do PMCMV em Viçosa (Figuras 20 e 21) foi 0 Benjamim José Cardoso (BJC), nome dado em homenagem ao pai do prefeito que iniciou os contatos com a CAIXA. Assim como o conjunto, as ruas internas a ele foram nomeadas em homenagem a políticos, familiares de políticos e outras pessoas que tiveram alguma importância para Viçosa, segundo critérios dos legisladores da época ${ }^{88}$. A entrada do conjunto dista cerca de $1,5 \mathrm{~km}$ do centro da cidade pelo caminho mais curto. As chaves das casas desse conjunto foram entregues no dia 16 de setembro de 2011.

Figura 20: Imagem do conjunto BJC pouco antes da inauguração, em 2011.

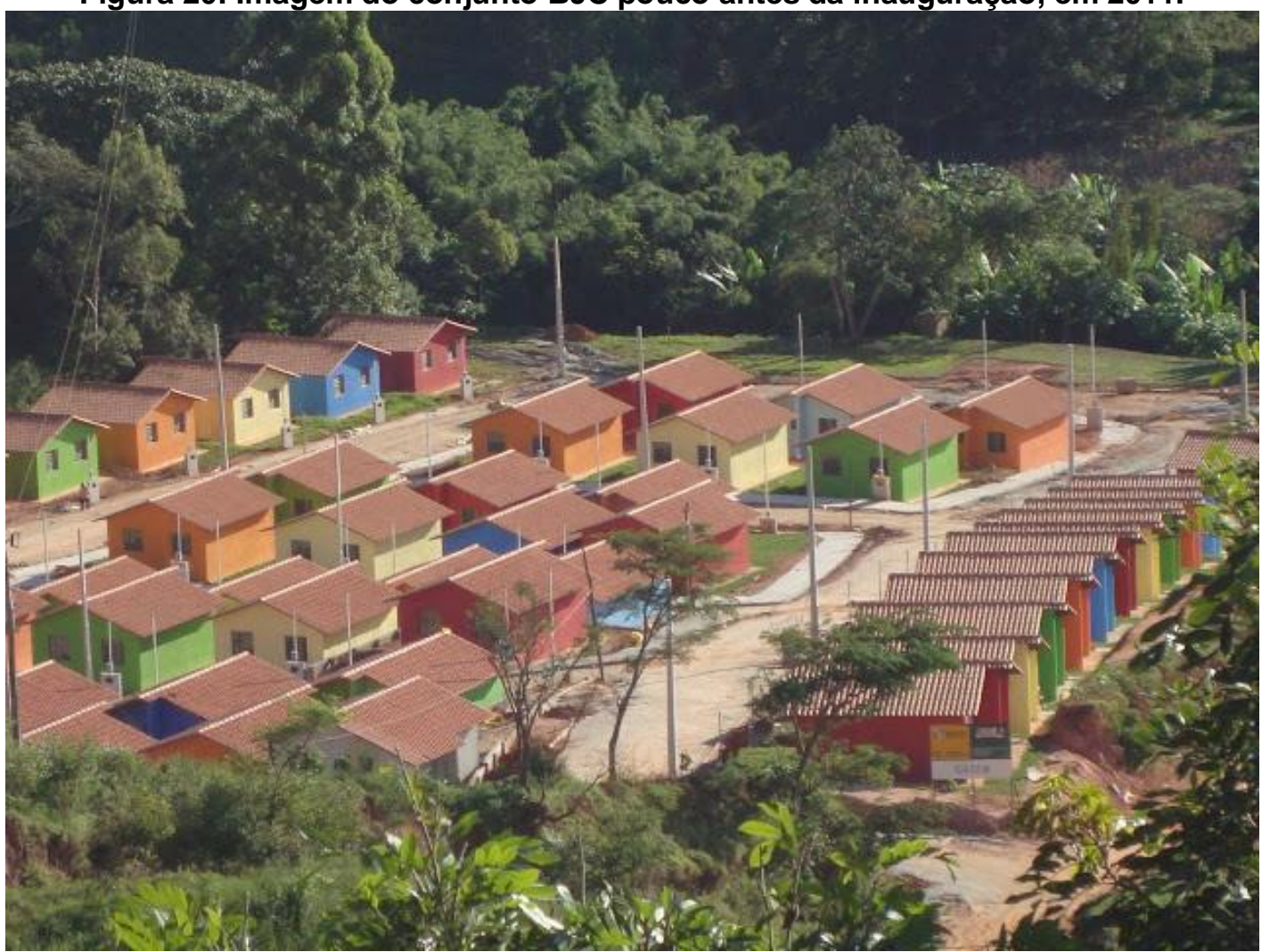

Ao fundo, vê-se a "praça" que foi deixada como equipamento de uso público ainda sem os brinquedos.

Fonte: <http://vicosacidadeaberta.blogspot.com.br/2011/04/conjunto-habitacional-esta-certomas.html>

Acesso em: 18 ago 2016.

87 Segundo relatos de duas moradoras entrevistas que faziam parte da ocupação. Em entrevista ao autor, Elaine Guimarães (2013) também fez um relato parecido da situação de habitação nos "predinhos", por dados coletados em entrevistas realizadas durante sua pesquisa, em 2012.

${ }_{88}$ Ver Lei $n^{\circ}$ 2173/2011 da Câmara Municipal de Viçosa, que dispõe sobre os nomes das ruas do conjunto. 
O conjunto é composto por 132 casas de $37 \mathrm{~m}^{2}$ cada, em lotes de $140 \mathrm{~m}^{2}$ distribuídos por dez ruas, formando treze quadras.

Os espaços da casa são: uma sala, uma cozinha, um banheiro, dois quartos e uma área de serviço externa à edificação, voltada para os fundos do lote. Na época, contava com um ponto de ônibus na entrada do conjunto, diversas lixeiras, mudas de árvores de três diferentes tipos, postes de energia e iluminação, ruas de mão-dupla com oito metros de largura e calçamento em blocos de concreto, calçadas de concreto de dois metros de largura e, como equipamento de uso público, uma pequena praça com brinquedos para as crianças do conjunto (apenas os brinquedos e bancos, sem outro mobiliário urbano).

Figura 21: Imagem do conjunto BJC pouco tempo depois da inauguração, em 2011.

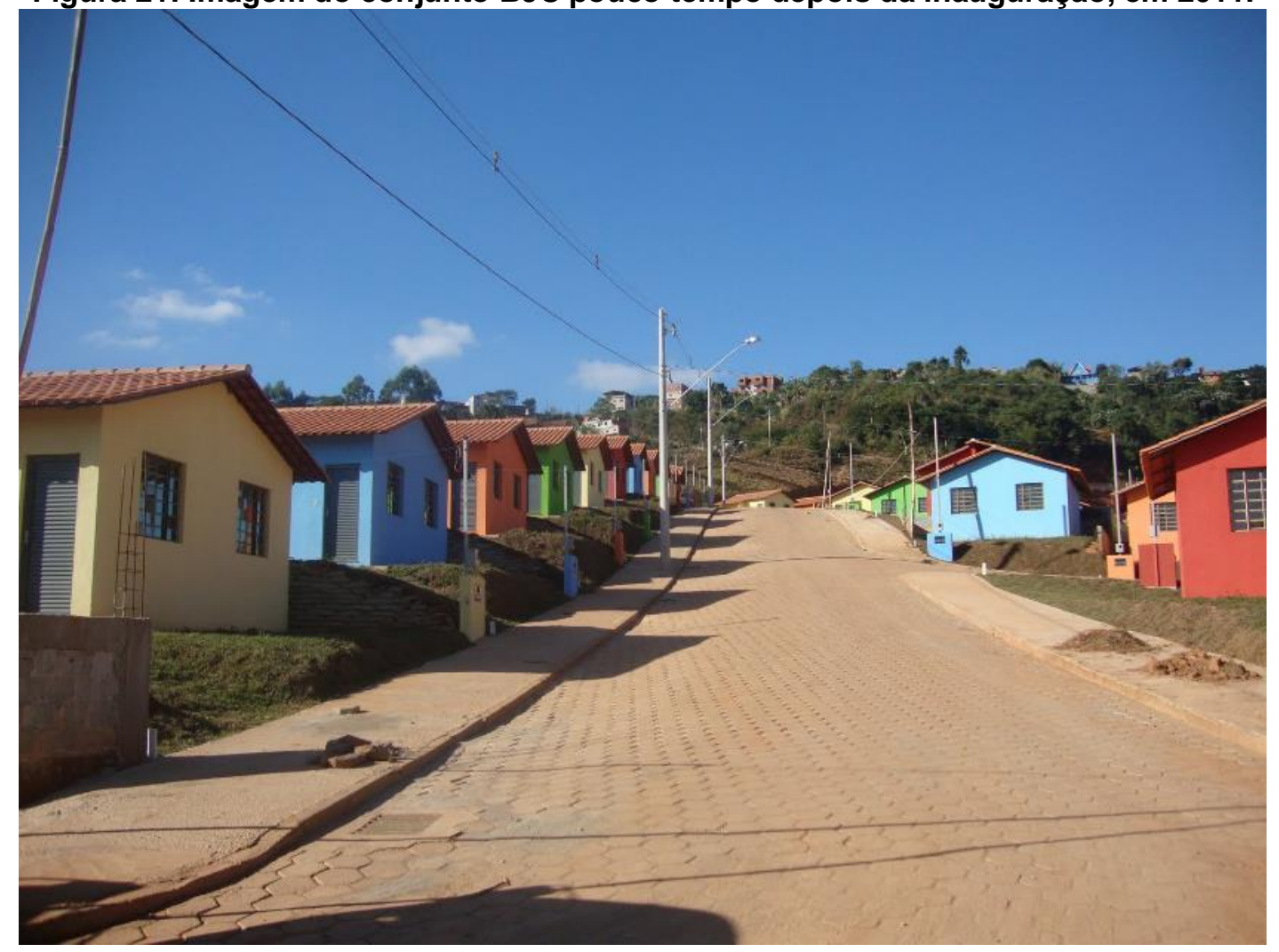

Ao fundo fundo, vê-se o início do Bairro Santa Clara, que é limítrofe ao bairro dos conjuntos. Fonte: <http://italostephanarquiteto.blogspot.com/2011/06/minha-casa-minha-divida-emvicosa.html>

Acesso em: 18 ago 2016.

O segundo conjunto foi construído logo em seguida e em 05 de julho de 2012 houve a entrega de suas chaves. O conjunto foi nomeado César Santana 
Filho (CSF), nome de um ex-prefeito da cidade, mas é popularmente conhecido como Sol Nascente, por sua localização que recebe luz solar direta por quase todo o período do dia, algo não muito comum em uma região de geomorfologia de mares de morros. As ruas, assim como no conjunto Coelha, também receberam nomes de figuras políticas e sociais consideradas importantes no município. Foram construídas 123 casas, obedecendo ao mesmo padrão e tipologia das casas do conjunto Coelha. As casas contam, porém, com aquecedor solar, diferentemente das casas entregues no conjunto Coelha.

O conjunto dista cerca de 2,2 km do centro da cidade utilizando apenas ruas e pelo caminho mais curto. Porém, há no conjunto uma escada hidráulica (Figura 22) para escoamento de água pluvial que é utilizada pelos pedestres como caminho para uma chegada mais rápida à malha urbana, como pode ser visto no Mapa de Mobilidade, em anexo.

Figura 22: Escada de escoamento de águas pluviais

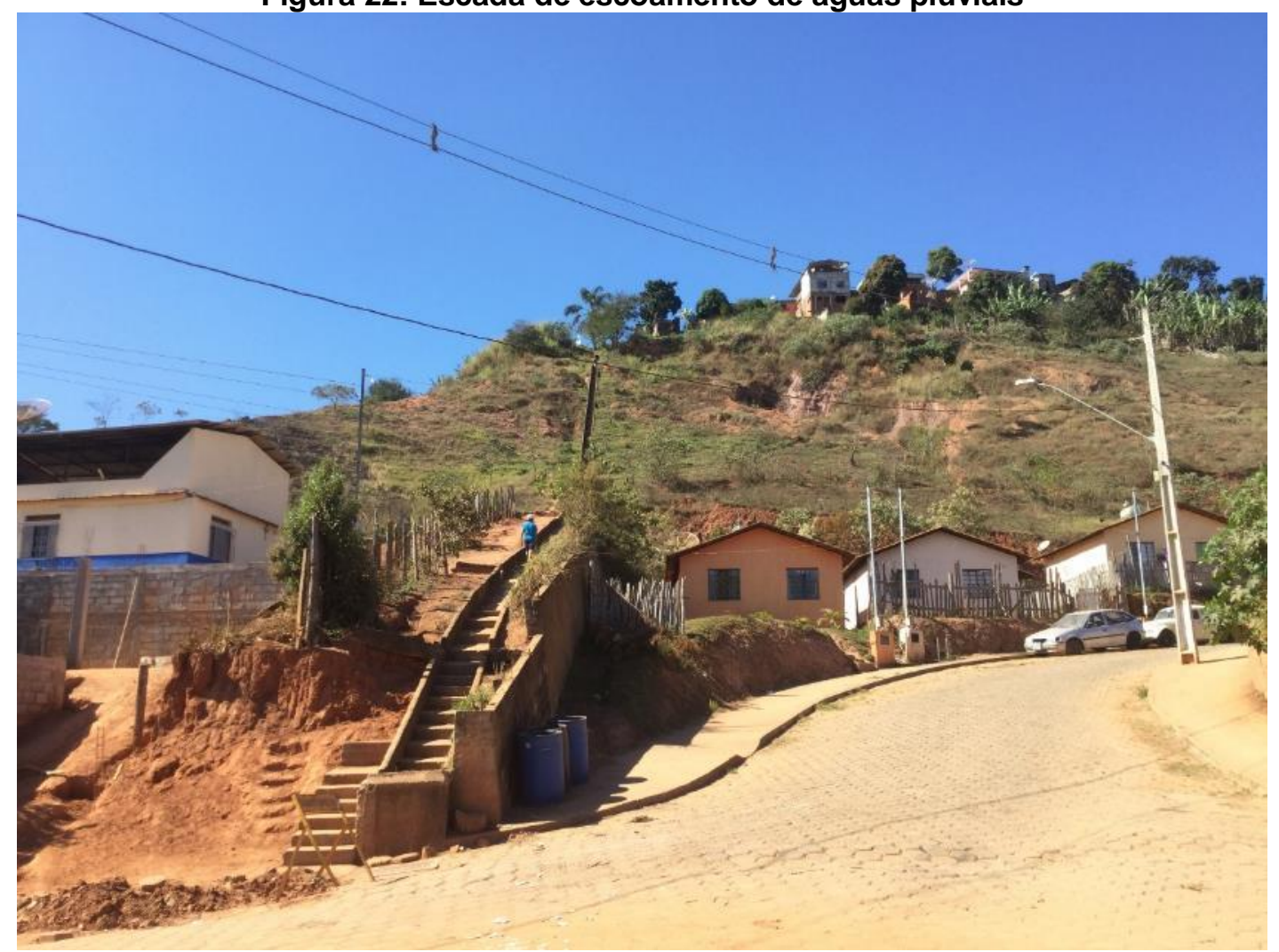

Ao fundo, vê-se o início do Bairro Santa Clara, que é limítrofe ao bairro dos conjuntos. Fonte: acervo do autor, 2016

Os acessos aos conjuntos podem ser realizados através de sua via principal, a rua Prefeito Carlos Raimundo Torres, com pavimentação de pedra 
fincada e que liga os dois conjuntos ao bairro Santa Clara e ao centro, ou ainda através de duas estradas de terra. Uma delas liga o conjunto Sol Nascente ao bairro Nova Era, e é a rota de tráfego do transporte coletivo, pois os ônibus não conseguem subir a principal via de acesso. Esse caminho é mais longo e raramente utilizado pelos moradores, a não ser, claro, pelo transporte coletivo. A outra via sem pavimentação liga o conjunto Coelha ao bairro Nova Viçosa. Essa via também raramente é utilizada, tendo em vista que o Nova Era não é uma região que concentra serviços e equipamentos públicos ou empregos. Ambas as estradas conectam os conjuntos também à regiões rurais da cidade.

Os moradores dos conjuntos apresentam realidades socioeconômicas semelhantes às dos bairros limítrofes e a outros bairros pobres da cidade. São, em geral, famílias jovens, sobretudo no conjunto Sol Nascente, no qual 46,5\% dos titulares das casas tem entre 18 e 35 anos, enquanto no Coelha corresponde a $30,3 \%$ (GUIMARÃES, 2013, p. 87). Ainda dentre os titulares, a maior parte é do sexo feminino, cerca de $93 \%$, o que reflete, em parte, a política pública de distribuição de renda Bolsa Família (Lei no 10.836/2004), da qual cerca de 70\% dos moradores são beneficiários (GUIMARÃES, 2013). A renda advinda do Bolsa Família é uma fonte de segurança financeira para boa parte dos moradores, visto que a renda familiar em quase $30 \%$ das casas é inferior a um SM, já somados os valores da assistência do Bolsa Família (GUIMARÃES, 2013, p. 91). Apesar de dados indicarem os conjuntos Coelha e Sol Nascente e imediações como uma região de pouca desigualdade em relação à renda (CRUZ, 2014), dentro dos conjuntos há uma percepção da desigualdade, tendo em vista que algumas famílias possuem veículos próprios, enquanto outras dependem do transporte público. Essa percepção de desigualdade gera comentários como relatado por Guimarães (2013, p. 94): "Para muitos só 'os mais pobres' é que deveriam ter sido selecionados".

Grande parte dos moradores trabalham em serviços informais ou não registrados, vivendo também de serviços temporários em condições de insegurança do emprego. Ainda nesse quesito, a maior parte das titulares do sexo feminino trabalham em serviços domésticos dentro e fora de casa e que metade delas não possuem carteira assinada (GUIMARÃES, 2013, p. 90). Cabe 
ressaltar também a presença de mães solteiras nos conjuntos, correspondendo a mais de $20 \%$ do total (GUIMARÃES, 2013, p. 88).

Não há dados sobre o número de crianças nos conjuntos, mas comparando-se os dados correlatos, como o número de mães solteiras com o número de jovens em estudos com campo amostral que inclui os conjuntos do $\mathrm{MCMV}^{89}$, somando-se à observação de campo desta pesquisa, pode-se afirmar que o número de crianças é grande. Como veremos adiante, elas estão presentes no cotidiano das famílias do conjunto e são, em alguns casos, fator determinante para a permanência da família no conjunto e de modificações físicas nas casas (Figura 23), além de serem o grupo que mais utiliza as ruas dos conjuntos e os que mais sofrem com a falta de espaços adequados (SOUZA, 2015, p. 62).

Figura 23: Rua do Conjunto CSF (Sol Nascente), em 2016

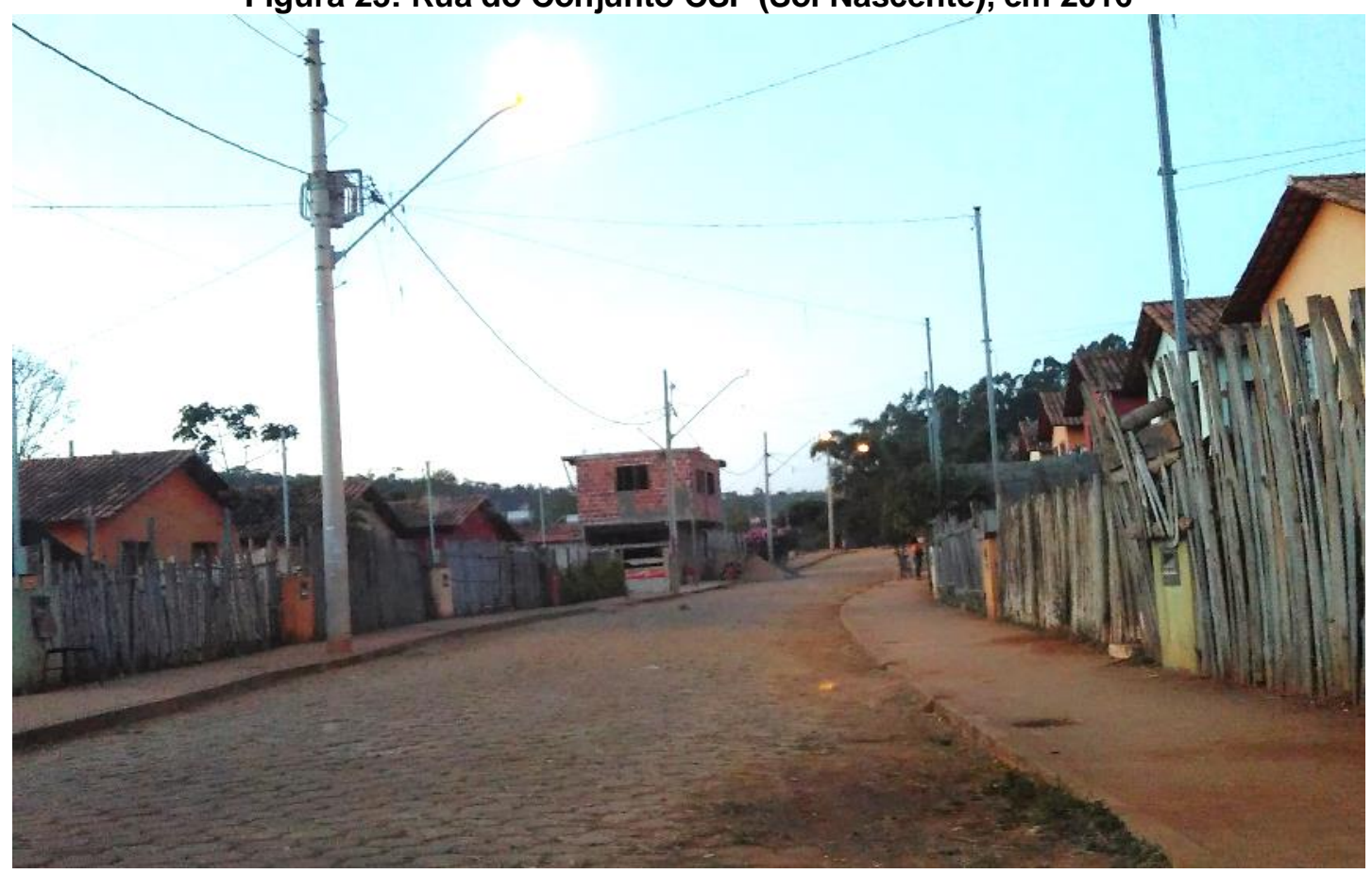

Ao fundo, vê-se que uma das residências está em obras de ampliação. Fonte: acervo do autor, 2016.

Atualmente, os maiores problemas são relacionados à mobilidade, pois cerca de $85 \%$ usam o transporte coletivo (SOUZA, 2015, p. 67) que dispõe de

89 Quase $25 \%$ dos habitantes dos conjuntos do MCMV e imediações são menores de 16 anos, cerca de $75 \%$ dos domicílios têm 3 ou mais moradores e têm-se um índice de 1,46 filhos por damicílio, segundo Cruz (2014, p. 40, 46 e 47) 
poucos horários e realiza apenas um trajeto (do Coelha até a UFV, passando pelo bairro Nova Era). Soma-se a isso a dificuldade de locomoção a pé pela via principal, muito íngreme e sem calçada para pedestres. Outro problema muito citado nos estudos realizados refere-se à criminalidade e à sensação de insegurança (GUIMARÃES, 2013; MOREIRA et al, 2015; SOUZA, 2015). Principalmente por esse motivo, quase todas as habitações construíram muros ou cercas no perímetro de suas casas, alcançando alturas que não permitem ao observador externo ver a casa além de seu telhado. Há, nos conjuntos, a presença do tráfico de drogas e alguns episódios de violência e criminalidade.

Além dos muros, cercas e gradis, outras modificações foram realizadas nas casas. Algumas casas apresentam uma extensão da cobertura visando a conformação de uma garagem. Outras apresentam a construção de novos cômodos e até mesmo aumentando o gabarito, transformando as casas térreas em sobrados, como pode ser visto da Figura 19. As ampliações e anexos foram, aparentemente, resultado de autoconstrução.

Recentemente, em 2016, houve a instalação, por parte da prefeitura, de equipamentos para a iluminação pública do logradouro que conecta os dois conjuntos, através do "Programa llumina Viçosa" (Primeira fase realizada pelo Contrato de Rateio no 056/2016). A localidade não possuía iluminação alguma, mesmo sendo passagem quase obrigatória para os moradores do Sol Nascente, por ser a via de acesso para o centro da cidade. Esse logradouro, como veremos adiante, passava a sensação de insegurança, fazendo parte dos relatos sobre episódios de violência da região. O logradouro abriga uma pequena Igreja Católica, recém-construída. A ela foi dado o nome de São Francisco de Assis, mesmo nome dado ao bairro criado a partir da implantação dos dois conjuntos aqui estudados.

\subsection{Legislação e política para HIS em Viçosa}

O histórico viçosense de legislações que abarcam a habitação de interesse social é recente. Até o final dos anos de 1990 a cidade teve apenas iniciativas particulares de promoção do acesso à terra urbana e à habitação. Isso não 
significou melhoria da qualidade de vida das pessoas, configurando-se como moeda política. Inicia-se em 1998 o acordo firmado entre a UFV e a PMV para a elaboração do primeiro Plano Diretor da cidade. Ainda antes da aprovação do Plano Diretor, em 1999, acadêmicos da Universidade e membros do corpo técnico da Prefeitura se uniram para requisitarem junto à Câmara dos Vereadores que o Código de Obras dos anos de 1980 fosse de fato cumprido, pois, segundo uma técnica atualmente locada no Instituto de Planejamento Urbano de Viçosa (IPLAM), "a legislação não tinha fiscalização nenhuma" e era "descumprida" por parte dos construtores ${ }^{90}$. Outra legislação com parâmetros urbanísticos que também não via sua aplicação geral, mesmo sendo mais permissiva que a legislação federal (como supracitado), era a Lei de Uso e Ocupação do Solo do início dos anos de 1990.

No início dos 2000 em meio às discussões sobre as legislações vigentes e a aplicação delas no município, a Câmara dos Vereadores aprovou o primeiro Plano Diretor da cidade (Lei $n^{\circ} 1383 / 2000$ ). Como verificado em conversas com membros da equipe da época, o Plano teve parte de seu caráter desfigurado durante seu processo de aprovação na casa legislativa, sobretudo no que tange à revisão e aumento do rigor para as legislações municipais correlatas. O Plano aprovado, então, contém diretrizes bem elaboradas sem, no entanto, dispor de planejamento para efetivação dessas diretrizes, tornando-as vagas. Dessa forma o instrumento não pôde servir como base sólida para pressionar, propor ou fiscalizar ações dos diferentes gestores municipais que passaram pelo executivo.

O PD de 2000 prevê a aplicação de instrumentos previstos na Constituição Federal de 1988, como o IPTU Progressivo, contudo, assim como as legislações municipais anteriores, esse instrumento não foi utilizado e as políticas fundiária

$90 \quad$ Fala de uma mulher membro do corpo técnico de elaboração do Plano Diretor de $2017 / 2018$ ao mostrar o recorte de jornal que publicou sobre a reunião de 1999. A fala foi realizada durante uma das reuniões de apresentação da Minuta de Revisão do Plano Diretor (em 05 de outubro de 2017), que viria a ser debatida na casa legislativa da cidade semanas depois, ao final de 2017. A técnica quis reforçar a questão do cumprimento das leis, ressaltando que, em Viçosa, não basta aprová-las, mas deve se fazer cumpri-las. 
e de habitação continuaram estagnadas. A seguir está o Capítulo sobre a Política de Habitação na íntegra:

\section{CAPÍTULO IV DA POLÍTICA DE HABITAÇÃO}

Art. 17 - A política de habitação objetiva assegurar a todos o direito à moradia, devendo orientar-se pelos seguintes princípios:

I - garantia de condições adequadas de higiene, conforto e segurança às moradias;

II - consideração das identidades e vínculos sociais e comunitários das populações beneficiárias;

III - atendimento prioritário aos segmentos populacionais socialmente mais vulneráveis.

Art. 18 - São diretrizes da política de habitação:

I - prover adequada infra-estrutura urbana;

II - assegurar a compatibilização entre a distribuição populacional, a disponibilidade e a intensidade de utilização da infra-estrutura urbana;

III - garantir a participação da população nas fases de projeto, desenvolvimento e criação de programas habitacionais;

IV - priorizar ações para atender aos residentes em áreas de risco e insalubres;

V - assegurar, sempre que possível, a permanência das pessoas nos locais de residência, limitando as ações de remoção aos casos de residentes em áreas de risco ou insalubres;

$\mathrm{VI}$ - desenvolver programas preventivos e de esclarecimento sobre a ocupação de áreas de risco ou insalubres;

VII - priorizar, na construção de moradias de interesse social, as áreas já integradas à rede de infra-estrutura urbana, sobretudo as de menor intensidade de utilização;

VIII - promover a regularização das áreas ocupadas de forma ilegal;

IX - incentivar a urbanização das áreas ocupadas por famílias de baixa renda, assegurando-Ihes acesso ao título de propriedade; $X$ - promover a progressiva eliminação do déficit quantitativo e qualitativo de moradias, em especial para os segmentos populacionais socialmente vulneráveis, residentes há mais tempo no Município;

XI - promover e apoiar programas de parceria e cooperação para a produção de moradias populares e melhoria das condições habitacionais da população. (VIÇOSA, Prefeitura Municipal de. Institui o Plano Diretor de Viçosa. Lei Complementar de 1383/ 2000.)

No que tange à HIS, o PD de 2000 previa duas áreas da cidade como próprias para a construção de moradias voltadas à população economicamente pobre. Essas ZEIS, como foram caracterizadas, estavam localizadas em áreas não ocupados e sem infraestrutura urbana (Mapa 07). A primeira delas localizase entre os bairros João Bráz e Santo Antônio. Caracteriza-se por um pequeno vale com um córrego, em uma de suas encostas há fragmentos de mata atlântica 
e na outra há uma plantação de café. A área ainda hoje é inacessível por vias públicas.

A segunda área apontada localiza-se entre os bairros Fátima e Nova Viçosa. A área é também um pequeno vale, isolado da malha urbana existente e acessível apenas por estradas de terra. Os conjuntos MCMV estudados aqui foram implementados em um local próximo à segunda área apontada no PD de 2000, distante menos de 1 quilômetro (Figura 24).

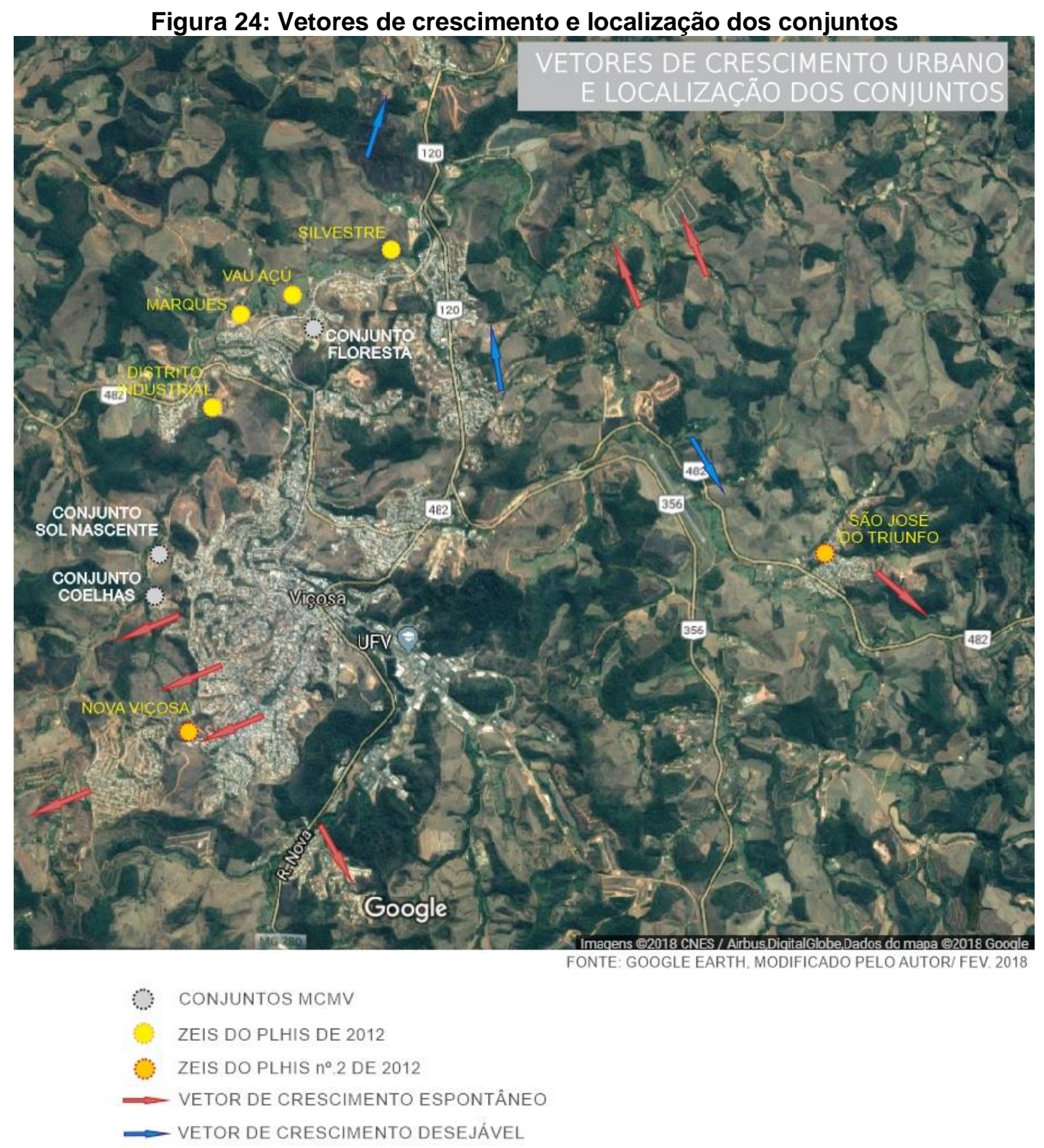

Fonte: Base Google Maps, modificado pelo autor, 2018. 
Alguns anos depois, em 2006, iniciou-se a revisão do Plano Diretor, de acordo com a Lei 10.257 de 10 de julho de 2001, o Estatuto da Cidade. O processo de revisão durou até 2008, quando a proposta foi apresentada à Câmara Municipal. Segundo um dos autores da revisão, de 2008 a 2011 "houve apenas uma tentativa de aprová-lo às pressas e desfigurado" (STEPHAN, $2011^{91}$ ). A revisão não foi aprovada. Assim como em 2000, as mudanças de maior profundidade nas legislações municipais correlatas foram motivo de discordâncias entre a equipe e a parte majoritária dos vereadores, que não as aprovaram. A revisão foi realizada já sob a tutela do Estatuto da Cidade e contou com a adição de instrumentos regulatórios do espaço urbano que visam a participação popular e uma cidade mais democrática.

Como observado por SILVA (et al, 2014, p. 16), a revisão do Plano Diretor de 2006 não inclui nenhuma das duas áreas apontadas no PD de 2000 como interessantes para ZEIS, nem mesmo como locais de expansão urbana desejável (áreas que, a princípio, estariam mais aptas a receberem investimentos da municipalidade). Apenas uma dessas áreas consta na revisão de 2006, mesmo assim, como de crescimento espontâneo.

Em dezembro de 2009 iniciou-se o processo de implementação do conjunto habitacional Coelhas (BJC) junto ao IPLAM, com a aprovação do projeto pelo órgão. Três meses depois, o Conselho Municipal de Habitação contatou o escritório CRB Arquitetos LTDA, dos arquitetos Humberto Carneiro e Marcus Rocha, contratados para a elaboração de um Plano Local de Habitação de Interesse Social (PLHIS) ${ }^{92}$. Entre 2010 e 2012 foram realizados os trabalhos de elaboração e apresentação para a cidade. A elaboração do PLHIS teve participação popular "quase nula" (STEPHAN, 2016, p.15) e logo após sua apresentação à Câmara Municipal, no início de 2012, os debates sobre sua aprovação cessaram. O PLHIS não foi aprovado, mas sua documentação consta

91 Em artigo online intitulado "Pacto Pró-Viçosa", de fevereiro de 2011. Disponível em: <http://italostephanarquiteto.blogspot.com.br/2011/02/pacto-pro-vicosa.html> Acesso em: 02 dez. 2017.

92 O PLHIS é requisito para adesão ao Sistema e ao Fundo Nacional de Habitação de Interesse Social (SNHIS-FNHIS, Lei $n^{\circ} 11.124$, de 16 de junho de 2005). 
no IPLAM e ele foi utilizado como material de apoio para a construção da revisão do Plano Diretor de 2017, o qual está em processo de tramitação na Câmara, como falaremos a seguir.

O PLHIS de 2012 determinou áreas de assentamento com infraestrutura urbana precária, tendo em vista que a municipalidade poderia pleitear recursos de regularização fundiária e de urbanização a partir da aprovação do PLHIS. Outras áreas foram apontadas para acolherem novos empreendimentos imobiliários voltados à faixa mais vulnerável da população. Na figura 25 está a indicação de áreas para a implementação de novas unidades habitacionais ou conjuntos, sendo elas localizadas na Comunidade dos Marques, no Distrito Industrial e nos bairros Vau Açu e Silvestre, com a posterior adição de regiões, uma no distrito de São José do Triunfo (Fundão) e outra no bairro Nova Viçosa, totalizando seis indicações de ZEIS.

Figura 25: Áreas elencadas para a implementação de novas HIS em Viçosa

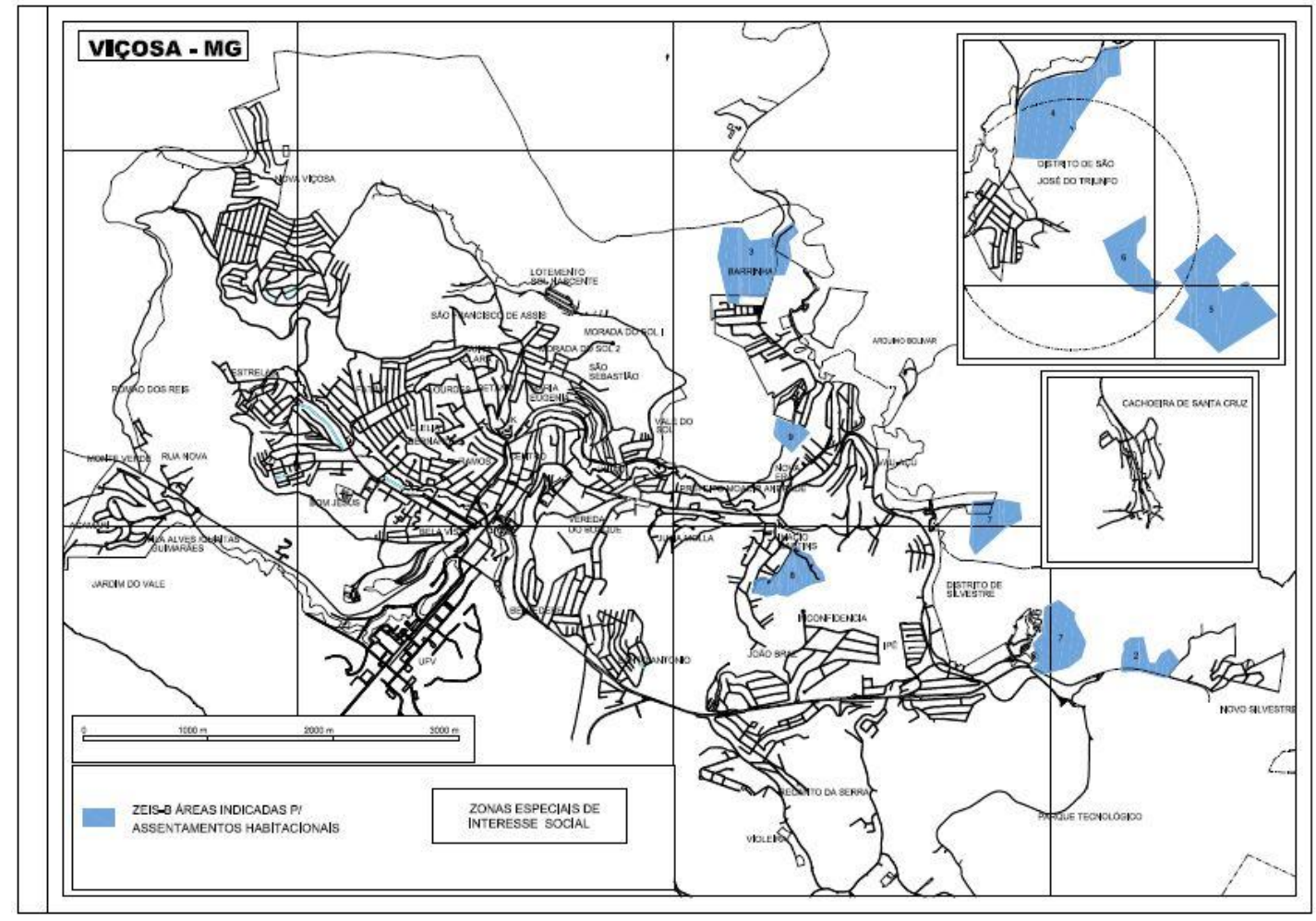

Fonte: CRB arquitetos, 2012, modificado pelo autor, 2018. 
Apenas a indicação do Vau Açu corresponde a um dos empreendimentos do MCMV em Viçosa, o Conjunto Habitacional Floresta. Este não é analisado nessa pesquisa, pois trata-se de um conjunto composto por prédios e em localização diferente, apresentando outras relações com o espaço urbano e fugindo do formato horizontalizado apreciado na pesquisa.

Como podemos observar, o MCMV Coelhas e Sol Nascente estavam, respectivamente, já concluídos ou em fase de construção na época de elaboração do PLHIS e, mesmo assim, a área de implantação dos Conjuntos não está indicada no mesmo como propícia para receber um novo empreendimento, algo que veio a acontecer meses depois com o Conjunto Sol Nascente. A área, todavia, foi apontada como de infraestrutura urbana precária, admitindo-se já na época da inauguração do Conjunto Coelhas que sua localização e urbanidade não eram adequados.

De acordo com o histórico relatado, podemos observar que os locais de implantação dos conjuntos habitacionais Coelhas e Sol Nascente (2011 e 2012, respectivamente) encontram-se na direção contrária tanto em relação aos vetores de crescimento urbano desejável designados pela revisão do PD em 2006, quanto para as localidades indicadas no PLHIS (que não chegou a ser apreciado pela Câmara para aprovação) desenvolvido no período de implantação do PMCMV na cidade. Cabe destacar ainda a não indicação de ZEIS na região central da cidade em qualquer das legislações citadas. Algumas das áreas indicadas encontram-se, na realidade, em regiões rurais do município, distantes dos serviços públicos e privados básicos, como postos de saúde, creches, escolas, padarias, etc. O PLHIS apontava ainda para a necessidade de construção de aproximadamente 4500 novas unidades habitacionais no prazo de até 23 anos a partir de sua aprovação, com custos estimados em quase 250 milhões de reais, custeados por diferentes fundos e programas públicos.

Em fase final de elaboração, há um Plano de Mobilidade (desenvolvido de 2016 a 2017) já apresentado à Prefeitura no qual consta (em projeto de lei preliminar) a necessidade de projeto urbanístico para a área do Bairro São Francisco visando a melhoria das modalidades de deslocamento (pedestres, automóveis e transporte público). 
Finalmente, em 2017 foi apresentado à Câmara Municipal o projeto de revisão do Plano Diretor de 2000. Essa revisão teve início em 2014, quando uma equipe de professores de Arquitetura e Urbanismo da UFV foi contratada para atuar conjuntamente com uma equipe multidisciplinar do IPLAM e com representantes da Câmara Municipal (um vereador da situação e outro da oposição, à época). O PD de 2017, como o chamaremos, foi entregue em maio de 2017, contou com reuniões em outubro e novembro do mesmo ano para apresentação aos vereadores(as) interessados e a representantes do empresariado local, moradores de áreas próximas à APP do Paraíso (também em fase de implementação) e pesquisadores.

Antes mesmo de ir à votação, o PD de 2017 encontra-se envolto pela disputa narrativa entre a equipe responsável pela elaboração e parte dos empresários da construção civil, contando com o apoio da Casa do Empresário da cidade, instituição de apoio ao empresariado local, mas que, como ficou claro nas reuniões, representa também o interesse de uma empresa construtora de fora da cidade. A disputa tomou contornos publicitários com a publicação, na imprensa local, de artigos favoráveis e contra o PD de 2017. O grupo representado pela Casa do Empresário alega que o PD é "elitista", pois não permitiria o parcelamento do solo em lotes pequenos nas áreas de expansão da cidade, limitando-os às pessoas de maior poder aquisitivo. A equipe de elaboração, por outro lado, alega que para o parcelamento em menores lotes há a previsão de implementação de ZEIS em áreas de expansão.

Assim como nas outras propostas legislativas, o PD de 2017 aponta áreas para ZEIS em zonas periurbanas de crescimento espontâneo da cidade. Essas áreas não foram devidamente delimitadas. Podemos observar que há a possibilidade de implementação de novas moradias em locais distantes da malha urbana consolidada e, cabe ressaltar, poderiam fazer das ZEIS formas de levar a infraestrutura urbana a terrenos de características ainda rurais, "urbanizando" essas áreas e provocando a valorização de suas terras, em uma estratégia de valorização e especulação fundiária semelhante à observada em cidades grandes com o $\mathrm{BNH}$, durante os anos da última Ditadura Civil-Militar brasileira. Devemos considerar, contudo, que o PD de 2017 aponta diretrizes 
que visam dirimir esse tipo de atuação do poder público e dos agentes imobiliários, como descrito no Art. 46 da proposta:

Art. 46 - As áreas delimitadas como ZEIS para novos parcelamentos e assentamentos habitacionais deverão observar os seguintes requisitos:

I - condições topográficas favoráveis;

II - dimensionamento mínimo dos lotes de acordo com o zoneamento estabelecido em lei específica;

III - acessibilidade urbana favorável;

IV - proximidade dos distritos municipais;

$\mathrm{V}$ - infraestrutura compatível com o assentamento pretendido; e,

VI - conservação da integridade das Áreas de Preservação Permanente (APP).

(Anteprojeto da Revisão da Lei no 1.383/2000, de 30/11/2000, denominada Lei do Plano Diretor do Município de Viçosa-MG ${ }^{93}$ )

Há de se considerar também que o PD de 2017 assinala para a possibilidade de implementação de novas moradias em regiões próximas ao centro da cidade. Essa possibilidade depende não apenas da aprovação do plano, mas, como vimos, da efetiva implementação de seus instrumentos e diretrizes, bem como dos instrumentos urbanísticos previstos na Constituição de 1988 e no Estatuto da Cidade.

Ainda um último aspecto deve ser colocado sobre a proposta de revisão do PD de Viçosa. O plano indica as localidades já contempladas com o PMCMV como de interesse para reurbanização, o que coloca o novo Plano Diretor de acordo com a possibilidade de obtenção de recursos governamentais para a melhoria da urbanidade dos conjuntos e seu entorno.

\footnotetext{
93 Documento cedido por membros da equipe de elaboração da Revisão do Plano Diretor entregue em 2017.
} 


\section{TRAJETÓRIAS DE VIDA E APROPRIAÇÕES DOS ESPAÇOS}

\section{PELOS MORADORES DOS CONJUNTOS EM VIÇOSA}

Apesar das duras críticas direcionadas aos resultados do PMCMV, algumas delas relacionadas no segundo capítulo do presente trabalho, pesquisas apontam para a satisfação dos moradores com relação às suas moradias (MCIDADES, 2014). Essas mesmas pesquisas (e outras) apontam para um alto índice de moradores que desejam se mudar de moradia. Como explicar que os mesmos moradores satisfeitos com suas residências demonstrem desejos de mudarem de localidade? Partimos da compreensão de que as apropriações dos espaços são indicadores de relações sociais e das relações estabelecidas entre os moradores e os espaços dos conjuntos e das moradias e que, a partir delas, podemos ter uma leitura da localidade e sua população em três aspectos: percepções sobre o conjunto, em sua arquitetura, urbanismo e tecido social; motivações de ida e permanência, além dos motivos de desejarem a mudança em determinados casos; as organizações sociais e políticas que, mesmo se incipientes, podem levar a um sentimento de identidade e de pertencimento e abrindo possibilidades para a desalienação do espaço e para a construção coletiva do lugar.

As apropriações (ou a pouca incidência delas) podem ser indicadores, ademais, da organização social e política de uma população e da tomada (ou não) do espaço enquanto lugar, territorializando-o em favor da população. Como os empreendimentos estão no início de suas histórias, as apropriações mostram (ou mostrariam) a realização da vida para além do habitat e as possibilidades de transformações dos espaços. As apropriações dos espaços são saídas para a vida pública, para a visibilidade e socialização, para as trocas, os conflitos democráticos estruturantes importantes para as formações identitárias e políticas ligadas ao espaço de moradia. 
Parte-se do pressuposto de que a moradia mais digna pode dar maior liberdade de ação para os moradores, sobretudo os que têm em suas trajetórias de vida a precariedade habitacional e financeira constantes. Assim, famílias que passam para um novo patamar de segurança habitacional e de renda podem começar a sair do ciclo de precariedades, tal qual Sísifo ${ }^{94}$, ou seja, um cotidiano que se inicia e se fecha a cada dia com poucas possibilidades de melhora e de saída do trabalho alienado. Um cotidiano no qual as famílias, a cada dia, se veem obrigadas a lutarem pelo sustento necessário ao próprio dia. Como afirmou uma das entrevistadas no presente estudo sobre sua situação anterior de moradia: "Tinha vez que eu olhava assim, eu até chorava. Porque eu assim: 'Gente, será que nós vamo viver nessa para sempre? Será que a gente nunca vai conseguir um lugar maior pra colocar esses menino?"' (Entrevistada 14, 47 anos, moradora do BJC)

Podemos entender a imobilidade social e política a partir da compreensão de Hannah Arendt (2010), quando a filósofa explica o espaço público das antigas pólis gregas e a relação da privatividade com a privação. Arendt nos mostra que o espaço público só era acessado pelos proprietários de terras e outros cidadãos cujas vidas não passavam pela necessidade diária do trabalho árduo de subsistência. Dessa forma, a política e a cidadania na pólis eram do alcance de parcelas privilegiadas da população grega. O espaço público é o objetivo, pois nele estão aqueles que podem se realizar enquanto seres "sociais" e "políticos". Assim, apenas quem venceu a privação deve intervir nos rumos políticos da cidade e não há realização do ser social e político sem que essa etapa tenha sido cumprida.

As apropriações tomam ainda uma dimensão maior quando temos a compreensão da centralidade da produção dos espaços urbanos na atual fase do capitalismo. Da alienação do espaço como materialização das alienações política e social, algo semelhante ao que vimos no terceiro capítulo sobre as concepções situacionistas e lefebvrianas sobre o espaço urbano. A partir também do que dissertamos acima, nos capítulos 2 e 3 , podemos entender a

${ }^{94}$ CAMUS, Albert. O Mito de Sísifo. 1942 
produção do espaço e seu caráter alienado com relação à população que nele habita. Se no espaço urbano estão materializadas as dimensões simbólicas, materiais e de arranjos sociais, seria a partir da tomada desses espaços pela população que se pode constituir uma cidade e sociedade de democracia radical, na qual as pessoas produzem e reproduzem de forma constante o espaço urbano a partir do encontro democrático de seus conflitos e desejos. Mas a produção do espaço como conhecemos esconde os conflitos, negocia-os e os repreende. Ademais, a história de produção dos espaços confere certa apatia social que minimiza os desejos coletivos e amplia os privados. É natural que poucos depositem esperanças e expectativas de cidades mais justas com o atual arranjo de forças produtoras do espaço.

Dos dados levantados em campo em observações e entrevistas, podemos fazer uma análise das apropriações dos espaços e dos fatores limitadores às apropriações. Ademais, podemos encontrar indícios das motivações de permanência ou, ainda, os desejos de saírem dos conjuntos. Encontramos também questões relativas ao cuidado e apego ao lugar, tanto dos ambientes internos à moradia quanto do conjunto e seus espaços.

\subsection{Trajetórias de vida, dinâmicas socioespaciais e apropriações dos espaços em conjuntos do PMCMV em Viçosa-MG}

A pesquisa empírica iniciou em 2015, em dois períodos de observações e levantamentos, julho e outubro. Nesses dois períodos foram realizados levantamentos fotográficos e anotações sobre os usos dos espaços públicos nas proximidades e dentro dos conjuntos habitacionais estudados, o Conjunto Benjamin José Cardoso e o Conjunto César Santana Filho, popularmente conhecidos como Coelhas e Sol Nascente, respectivamente. Posteriormente, já realizados os contatos com famílias moradoras dos conjuntos, as entrevistas aqui analisadas foram realizadas em uma nova fase de levantamento de dados.

Das dificuldades de campo para o levantamento dos dados, destaca-se a desconfiança por parte dos moradores abordados. Isso poderia se passar por uma "mineiridade", uma característica dita do "mineiro típico". Nas palavras de 
Drummond 95: "Um bom Mineiro (...) não estica conversa com estranho". Contudo há de se levar em consideração que os moradores foram abordados entre julho e agosto de 2016, época na qual iniciam-se as pesquisas eleitorais nos municípios por parte dos candidatos aos cargos públicos na Câmara Legislativa e Prefeitura Municipal. Em uma das entrevistas o morador afirmou: "E sempre vem, agora, por exemplo, agora esse mês, daqui uns dois, nesse mês vai começar alguns vim dando presentezinho. É candidatos, né?" (Entrevistado 12, 66 anos). Em outra entrevista, a moradora revela: "A gente recebe muita gente mesmo é em época de eleição! [risos] Os prefeito vem, os vereador vem... só pra ganhar um votinho, mesmo!" Depois de perceber esse fator, a abordagem passou a vir acompanhada de uma explicação da ausência de intenções políticas eleitoreiras relativas ao estudo.

Outro fator de resistência de alguns moradores em serem entrevistados está na relação com a segurança familiar e o tráfico de drogas, questão levantada de alguma forma em todas as entrevistas realizadas. Um dos moradores abordados disse que faria a entrevista, com a condição da não utilização de gravador. Quando viu que a entrevista seria acompanhada de anotações, desistiu e afirmou preferir "evitar problemas". Mesmo garantindo seu anonimato, o morador em questão não aceitou a entrevista e convenceu sua esposa a também não ser entrevistada. Sem áudio ou anotações, a entrevista não foi realizada.

Cabe ressaltar que este morador adaptou sua garagem para um estabelecimento comercial, algo que poderia gerar problemas legais para a família. Não podemos concluir, ao final, se o fato de negar a entrevista já agendada está relacionado com as relações de domínio territorial do tráfico de drogas ilegais ou com a atividade comercial "clandestina" desenvolvida na moradia ou, ainda, uma soma desses dois fatores. Independente do peso de cada um desses fatores, fica clara a influência desses "poderes" (organização criminosa e Estado) na falta de liberdade de ação e fala dos moradores.

${ }_{95}^{95}$ Visto em: <https://www.cartacapital.com.br/cultura/o-poeta-bem-de-perto> Acesso em: 31 jan. 2016. 
Assim, foram abordadas dez famílias, das quais 8 se prontificaram a responder as perguntas do estudo. Dessas, uma casa não foi visitada por conta dos horários de trabalho dos moradores. Dessa forma, seis casas foram visitadas somando os dois conjuntos. Uma delas em situação especial, pois se tratava de uma residência ocupada. Nesta, a titular abandonou a casa e a família entrevistada, ao saber do abandono, passou a residir na casa. Poucas residências estavam desocupadas nos dois conjuntos. Das casas vazias, três apresentavam sinais de depredação, incluindo a casa ocupada por uma das famílias entrevistadas.

Como anteriormente mencionado, os moradores dos conjuntos vieram de diferentes realidades com relação à habitação. A maior parte tem em comum o fato de terem vivido no último local de moradia algum fator de precariedade da habitação ou o ônus excessivo com o aluguel. Ou seja, as habitações não apresentavam as características necessárias para uma moradia digna, de modo geral um local de abrigo, descanso, de intimidade, de segurança (aproximadamente $40 \%$ ); ou representavam uma despesa que incidia sobre a segurança econômica da família (cerca de $60 \%$ das famílias ${ }^{96}$ ). Eram famílias enquadradas em pelo menos um dos índices componentes da vulnerabilidade social, e este passado influenciou na motivação de mudança de local de moradia e em parte das ações realizadas na nova casa.

Dos moradores entrevistados nessa pesquisa, alguns moravam nas ocupações irregulares chamadas de "predinhos", no Alto Santa Clara97 (Figura 26). Esses edifícios eram pequenos sobrados construídos lado a lado e que foram abandonados pelos proprietários, por motivo desconhecido. As edificações estavam em um processo de degradação quando foram ocupadas na virada dos anos de 1990 para os anos 2000. Segundo a entrevistada 14 (de 47 anos, moradora do Coelhas), eram seis edificações que comportavam, cada, duas ou três famílias de diferentes tamanhos, em um espaço originalmente

\footnotetext{
${ }^{96}$ CARVALHO, STEPHAN, 2016

97 Também conhecidos como "Predinhos dos Araújos", segundo Carvalho e Stephan (2016).
} 
projetado para uma família. Cada família ocupava um andar ou, em alguns casos, duas famílias em um mesmo andar.

Ainda segundo a entrevistada 14: "Na parte que eu morava era... uma cozinha e um quarto. Bem apertado! Cinco menino! [Risos] Tudo pequeno na época!". Na sequência da mesma entrevista, a moradora revela que também havia um banheiro a disposição de sua família, mas que não era "assim perfeito" como o da sua atual moradia. Ao banheiro faltava água encanada, sobretudo, assim como para o restante da casa.

Figura 26: Último "predinho" da ocupação no Alto Santa Clara.

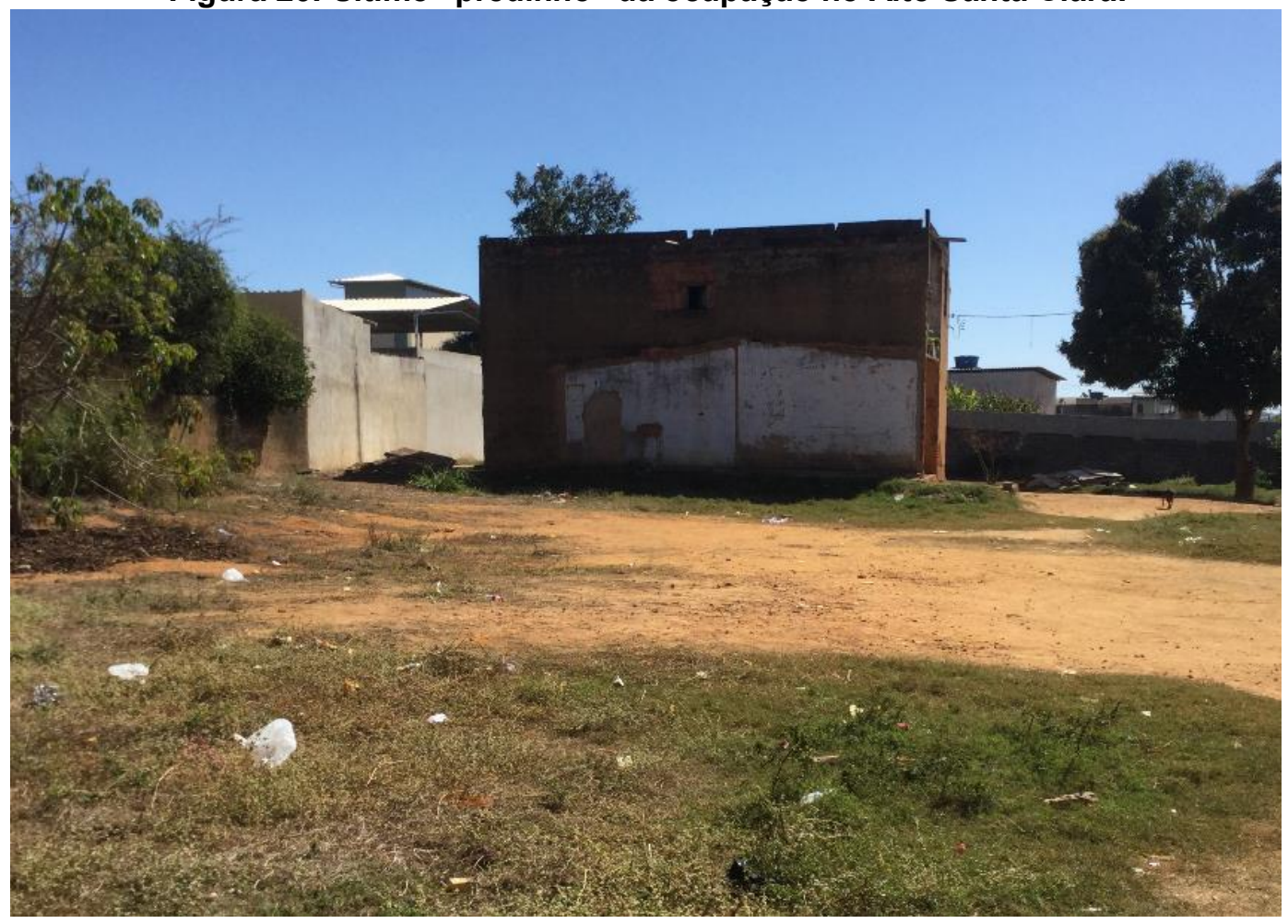

Cada construção dessa abrigava 2 ou 3 famílias. Podemos ver o último dos "predinhos", cujo ocupante não quis sair. $\mathrm{O}$ edifício foi demolido poucos meses após esse registro.

Fonte: Acervo do autor, 2016.

A situação de moradia dessa entrevistada revela um cotidiano de privações, de preconceito por parte de moradores de outras localidades ou até mesmo de alguns vizinhos: "(...) nós foi muito humilhado naquele lugar, mesmo. A gente... o pessoal passava, cuspia, fazia 'em nome do Pai'”. Em sua residência eram sete pessoas dividindo três cômodos, dois adultos e cinco crianças. A moradora descreveu a organização do espaço dessa moradia, como transcrito a 
seguir. Nota-se a falta de privacidade vivida pelo casal e o espaço diminuto dividido entre os filhos e filhas:

Nós pôs uma cama. Tipo uma cama de casal na cozinha. Pra organizar os menino. E uma cama de casal no quarto pra mim mais o pai deles dormir. E ali na cozinha, mesmo. Igual tinha a cama ali [apontando os cantos da sala, demonstrando com os dedos] e tinha, do lado, tinha... de um lado, assim, tinha uma pia. $E$ do outro lado era um fogão. Um fogão de lenha dentro de casa. E a gente cozinhava ali, mesmo. E quando num... e ali era um... era um embolado! Nosso Deus! (Entrevistada 14, de 47 anos, moradora do BJC).

Os ocupantes enfrentaram a situação de falta de água e luz, conseguidos de maneira improvisada ou pela ajuda de vizinhos, como relata a entrevistada: "A gente armazenava a água ali. Naqueles tambor ali. Aí dava, né!" (Entrevistada 14, de 47 anos, moradora do BJC) Outros empecilhos também eram "resolvidos" pela solidariedade de vizinhos que os conheciam. Destacamos que as diferentes administrações municipais tinham total conhecimento da situação das famílias ocupantes desses edifícios e, como relatado em entrevista, a Prefeitura chegou a fazer a ligação de água para os moradores.

Aí, antes do prefeito vim pra organizar as coisa direitinho pra gente... eles colocaram um chafariz grande de água. Aí, quando acontecia que caía água, nós ficava até tarde da noite pegando água. Tinha vez que no outro dia a gente tinha que amolar até os vizinho que conhecia a gente já, né! Fornecia água pra gente. Aí, antes, a gente ilumiava com luz de vela. Outra hora era lamparina, né! (Entrevistada 14, de 47 anos, moradora do BJC)

Contudo, nem todos os moradores da região reconheciam as dificuldades enfrentadas pelas famílias. A ocupação motivou atitudes de preconceito de alguns moradores, que entendiam a localidade como abrigo para pessoas que cometeriam crimes como furtos e venda de drogas ilícitas: "Pela fama que eles falava lá que muitos mexia com as coisa... maconha, né! Passava a mão nas coisa dos outros" (Entrevistada 14, de 47 anos, moradora do Coelhas). Outra antiga moradora dos "predinhos" relata que na convivência entre os moradores da ocupação havia o auxílio mútuo entre as famílias e que parte deles mantiveram contato após a mudança para os conjuntos habitacionais. A solidariedade entre ocupantes pode ser entendida também como uma forma de resistência, tendo em vista que compartilhavam de dificuldades semelhantes e se encontravam todos em situação de vulnerabilidade econômica e de incerteza 
quanto a permanência no local. Apesar da boa convivência, a entrevistada relata também que a localidade tinha um cotidiano de conflitos familiares:

Mas era um lugar muito bom. Só que tinha muita gente que bebia muito, que brigava muito. Nossa, era briga todo dia, toda hora você via briga. Mas era um lugar bom, eu gostava dali. As pessoas, tudo, umas pessoas boas. Todo mundo ajudava todo mundo. (Entrevistada 22, de 25 anos, moradora do CSF)

Ressalta-se que todos os moradores das ocupações foram realocados para os três empreendimentos do PCMVM na cidade, dois deles os estudados no presente trabalho. Apenas um morador continuou na ocupação por mais alguns anos. Deve-se pontuar também que as moradoras entrevistadas recebiam o Bolsa Família mesmo antes de se mudarem para os conjuntos, pois já estavam cadastradas no CRAS (Centro de Referência da Assistência Social) da cidade.

Havia ainda outros problemas relacionados à ocupação. As edificações apresentavam problemas em sua estrutura, com rachaduras e quedas do reboco das paredes. Contudo, o fator que mais parece ter motivado a mudança das famílias para as casas dos conjuntos do PMCMV são as crianças. A importância da questão familiar foi expressa pela entrevistada 22, também ex-moradora dos "predinhos":

Aí a mulher lá do CRAS me chamou lá um dia pra falar que saiu pra mim lá no bairro Floresta [MCMV na tipologia de apartamentos]. Aí nisso eu fui e desisti porque minha família tava tudo aqui no bairro São Francisco de Assis, nas casinhas, né! Eu falei: "não quero ficar separada, não". Que eu achei que só eu que ia ficar lá. Aí eu tinha desistido e ela falou comigo que se alguém, né, se tivesse alguma vaga pra cá que ela ia me encaixar. Aí um dia ela me ligou e falou comigo que tinha saído pra mim aqui. Aí eu falei “"nó, mil maravilhas". Aí acabou que depois saiu pra minha irmã lá [no bairro Floresta]. Se eu soubesse, né, não tinha desistido. É, mas teve bom. (Entrevistada 22, de 25 anos, moradora do CSF).

A mesma entrevistada demonstra nostalgia com relação a uma de suas habitações anteriores, mesmo sendo ela precária, pois chegou a morar na ocupação dos "predinhos". A moradora relata que em sua vizinhança atual há muitas "brigas" domésticas, o que atrapalha a tranquilidade do lugar, qualidade que ela destaca como importante para sua permanência. Adiante, quando 
perguntada se não havia esse problema em seu antigo bairro de moradia, a entrevistada responde:

(...) eu morei ali no Santa Clara a minha vida toda, desde que me entendo por gente e, assim, sempre foi bom, muito bom. Igual, eu já morei nos predinhos, ali. Assim, tinha todo mundo junto ali, que era aquela bagunça toda, mas eu amava aquele lugar, era muito bom.

A percepção de que a habitação era boa, mesmo precária, explica-se pelas relações familiares ali estabelecidas, como podemos notar ao conectarmos suas duas falas supracitadas. Dessa forma, inferimos a importância dos laços familiares na avaliação do local de moradia, sobrepondo-se ou escamoteando os problemas estruturais das habitações. Diferentemente da entrevistada 14 (de 47 anos, moradora do BJC), que "pedia a Deus" a oportunidade de sair daquela ocupação. Contudo, podemos apontar para a importância da família também nesse caso, quando a moradora revela, em diferentes pontos da entrevista, como suas ações foram norteadas pelo desejo de bem-estar de seus filhos e filhas: "Eu pensava só nos menino" (Entrevistada 14, de 47 anos, moradora do BJC). Se para uma a mudança representou o distanciamento com os laços familiares e de amizade estabelecidos, a outra vislumbrou uma oportunidade de estruturação de sua família a partir de uma moradia mais digna.

Em entrevista com outras famílias de moradores dos conjuntos, o fator familiar não ganha tanto destaque na motivação para a mudança de local de moradia tanto quanto para essas duas famílias que passaram pelas ocupações. Para a maior parte dos entrevistados, a questão principal foi estritamente econômica. Assim como averiguado em outros trabalhos (GUIMARÃES, 2013; SOUZA, 2015; CARVALHO e STEPHAN, 2016), a questão do ônus excessivo com o aluguel foi um fator de grande importância para o cadastro das famílias no CRAS e no programa, e também motivou a mudança das famílias para os conjuntos quando da oportunidade de escolha.

Das famílias entrevistadas, duas revelaram dificuldades ou impossibilidade do pagamento do aluguel na moradia em que estavam (13 e 21). Uma delas atualmente ocupa de forma irregular uma das casas do conjunto BJC que, segundo a moradora relata, foi abandonada pela proprietária. A moradora relata 
uma trajetória marcada por migrações, incertezas de emprego e moradia. Nordestina, nascida no estado da Paraíba, migrou para São Paulo. Na capital paulista conheceu e se casou com um mineiro de Porto Firme, cidade vizinha à Viçosa. Logo após a morte de seu marido, veio com seus quatro filhos a Minas Gerais para a cidade de seu companheiro. Em seguida, em 2009, mudou-se para Viçosa, quando foi morar já no Bairro Santa Clara.

Ela relata que seus deslocamentos cotidianos eram geralmente dentro do bairro Santa Clara, mesmo, onde conseguia trabalho como empregada doméstica e contava com uma rede de comércio e serviços próximos. Relata também que não mantinha vínculos de amizade com vizinhos, apenas de cordialidade. À época de sua mudança, a entrevistada relata que "muita gente" falou com ela sobre a residência vazia no conjunto Coelhas. A moradora não conseguia arcar com os custos do aluguel, que chegou a ser pago pela Prefeitura Municipal pelo período de três meses. Após esse período, segundo relata, ainda sem condições de pagar o aluguel, a proprietária do imóvel pediu a casa, deixando-a sem alternativas além de ocupar a residência vaga do Coelhas. Para essa moradora, a ocupação representou a possibilidade de continuar nas proximidades de sua antiga moradia. Assim, suas filhas continuaram frequentando a mesma escola (Figura 27): "Era muito bom. Era tudo perto, né! Morava perto do Pedro Gomide [escola municipal] ali, perto do Posto de Saúde. Bem pertim" (Entrevistada 13, de 47 anos, moradora do BJC)

A moradora tem como ocupação o trabalho doméstico. Estava desempregada na época da entrevista e realizava faxinas eventuais. Quando ainda morava no Alto Santa Clara, trabalhava em casas no próprio bairro, segundo ela relata. Ela narra ainda que procurou a Assistência Social do Município para cadastrar-se no PMCMV em 2010, mas não pôde ir adiante com o cadastro por estar a apenas um ano na cidade, o que não é permitido pelas regras do programa.

Mas eu fui lá fazer a inscrição da minha e eles não aceitaram porque só tinha um ano que eu tava em Viçosa. Porque eu vim pra cá em 2009 e em 2010 começou a inscrição das casinha, pra em 2011 sair. Ai eles não aceitaram porque tinha que ter 
cinco anos morando aqui, por isso que não fez a minha. (Entrevistada 13, de 47 anos, moradora do BJC)

Ainda segundo a moradora, sua situação de ocupação é de conhecimento da proprietária. Quando indagada a proprietária, a entrevistada diz que ela "não gostou da casa" e a abandonou pois teria uma outra opção de moradia. Ainda segundo relata, a atual moradora e a então proprietária do imóvel conversaram: "Já, ela falou, assim, que eu podia ficar na casa, que [ela] não ia ficar aqui. Que aqui não é lugar pra ela. Aí eu fiquei”.

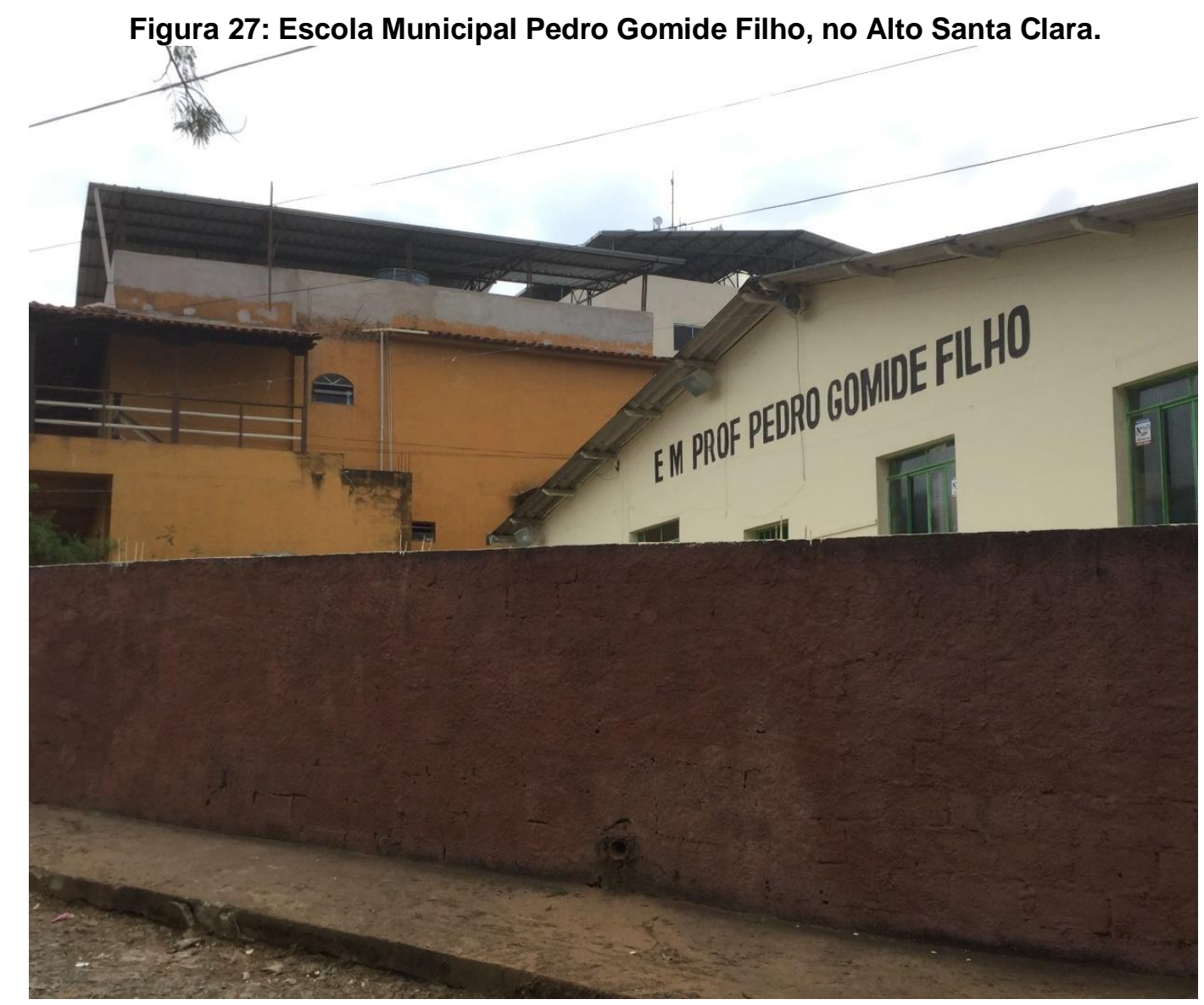

Fonte: Acervo do autor, 2016.

Pela situação de ocupação e pela precariedade da habitação na qual reside, a entrevistada deposita esperanças de que um novo conjunto habitacional do programa será construído na região. Essa esperança provém das tratativas da administração municipal veiculadas em 2013 e 2014 pela imprensa local, nas quais o então prefeito e a Caixa estariam negociando um novo conjunto que seria implantado, preferencialmente, na área de uma antiga fazenda que separa os dois conjuntos aqui estudados. 
A implantação desse novo conjunto, que teria 720 casas, significaria também uma demanda por mais de horários de ônibus e pela construção de equipamentos públicos como creche e posto de saúde, três das principais demandas da população (GUIMARÃES, 2013; CARVALHO et al, 2015). Dessa maneira, um novo conjunto desperta o interesse também dos moradores dos conjuntos existentes, tendo em vista os problemas com horários do transporte público, a grande população infantil e a carência de equipamentos públicos em locais mais acessíveis. Os conjuntos, contudo, não foram construídos, o que motivou reclamações populares e denúncias na Câmara Legislativa Municipal quanto a supostas irregularidade no processo ${ }^{98}$.

Três famílias estavam em situação de coabitação (entrevistadas 11, 12 e 22). Um dos moradores entrevistados revelou que havia iniciado a compra de um terreno visando construir no futuro, contudo as prestações do terreno comprometeram sua e renda e como sua família vivia em coabitação com a família de sua filha e a de seu filho, decidiu por abandonar o negócio e se inscrever no programa habitacional.

Esse mesmo morador expôs seus planos de continuidade no conjunto tendo em vista a possibilidade de investir na moradia, realizando reformas e construindo um segundo pavimento assim que possível. Segundo ele, alguns moradores já venderam suas casas por " 15 mil" reais, mesmo ela tendo o valor nominal de 46 mil reais: "Mas isso não é casa de quarenta e seis mil. Já veio uma vez aqui um cidadão querendo comprar a casa, o preço que nós demos. Ora, eu não pretendo vender minha casa, mas o preço que nós demos, por menos de setenta mil eu não vendo não!" (Entrevistado 12, 66 anos, BJC).

\footnotetext{
98 Segundo o vereador Idelmino Ronivon: "o Prefeito pede para disponibilizar as 720 unidades para a CHEREM. Porém deve-se levar em consideração que outras construtoras chegaram primeiro, ou seja, entendemos que há uma administração de grupos", reiterando ainda que a citada construtora teve seu projeto reprovado pela Caixa à época. Ainda segundo o vereador, as tratativas entre a Prefeitura e a Caixa foram intermediadas pelo filho do então prefeito, que à época não ocupava cargo público, o que seria outro indício de má conduta.

Disponível em: <http://www.vicosa.mg.leg.br/institucional/noticias/2014/03-2014/vereadoraponta-irregularidades-em-procedimentos-do-executivo> Acesso em: 20 jan. 2017
} 


\subsection{A mudança para os conjuntos e os primeiros problemas}

As famílias que viviam em condição aparentemente mais precária foram as que se mudaram mais rápido para os conjuntos. Segundo os moradores entrevistados, algumas poucas famílias se mudaram ainda nos primeiros dias após a entrega das chaves, dando a entender que houve ainda um tempo para a organização da antiga moradia e das questões referentes à mudança. Como afirma a entrevistada 14:

Nós passamo uns dia assim, nós começou a organizar lá em cima. Arrumando o que tinha, né! Pra trazer aqui pra baixo. Aí arrumamo um caminhão. Pedimo um frete pra trazer os móveis, os poquim que a gente tinha. Aí a gente foi organizando. A gente foi organizar. Conseguimo mesmo as coisa foi depois que nós descemo cá pra baixo. (Entrevistada 14, de 47 anos, moradora do BJC)

Por não haver quase nenhuma casa na área escolhida para implantação dos conjuntos (apenas casas das antigas fazendas), não havia também padrões de comportamento ou normas socialmente construídas. O padrão de comportamento é, então, construído de acordo com a convivência entre os moradores. A princípio, não havia uma identidade do bairro à qual se adequar ou escapar. Por exemplo, um espaço consolidado apresenta sinais muito mais claros de apropriação, pois elas são espacialidades e temporalidades, ou seja, exigem usos e tempos que vão sendo compartilhados entre seus sujeitos. Portanto, há de início dois fatores que influenciam nas apropriações dos espaços e em suas limitações, as condicionantes espacial e temporal.

Uma das críticas feitas ao PMCMV em geral é sobre os processos de participação dos moradores nas diferentes etapas de implantação dos conjuntos. A primeira etapa de implantação é a escolha do terreno. No capítulo 2 exploramos a questão da localização e o problema da segregação, tanto em sua perspectiva teórica quanto histórica relacionada às políticas para a habitação de interesse social. Para os MCMV de Viçosa não houve diferenças quanto a isso. Os terrenos foram escolhidos pela construtora, sem participação das pessoas que viriam a morar nos locai. Os terrenos estavam (e ainda estão) fora da malha 
urbana consolidada, segregados da cidade por um morro que se constitui como uma barreira geográfica que dificulta o acesso à cidade.

A escolha da localidade levou em consideração o preço do terreno e, segundo a narrativa do então prefeito Raimundo Nonato Cardoso, a implantação do terreno acarretaria em levar serviços de água, esgoto, luz e transporte para uma área da cidade que pouco contava com esses serviços, qual seja, a parte alta do Bairro Santa Clara. Outra justificativa elencada para a escolha do terreno para a implantação do conjunto BJC foi, segundo processo que consta no IPLAM foi que a localização facilitaria a acessibilidade e a implantação ( $n^{\circ}$ 0003/09, segundo SILVA e ANDRADE, 2014). Ainda segundo o mesmo processo, há harmonia na implantação do conjunto BJC:

com o meio ambiente e colaborará para o crescimento econômico, social e cultural do município de Viçosa, com a ocupação ordenada do solo em suas unidades residenciais e consequentemente, fomentando o comércio local e da região (apud SILVA e ANDRADE, 2014, p.1148)

É importante ressaltarmos um dos motivos para a não implementação de um novo conjunto no Bairro São Francisco de Assis, pois revela sobre o estado de urbanização e inserção urbana do local: "A Cherém [construtora] então passou a negociar a compra de um terreno nas proximidades da Coelha, o que ainda não ocorreu por que a área não é urbanizada. O local necessita de investimentos, tais como construção de cerca de mil metros de asfalto e de uma ponte de concreto, além de outras benfeitorias tais como iluminação pública, rede de água e esgoto, dentre outros" (Jornal Folha da Mata de 12 de setembro de $2014^{99}$, grifos nossos).

Essas narrativas são desconstruídas a partir dos relatos dos moradores que habitavam o bairro antes de irem para os conjuntos do MCMV. Os moradores apontam, de modo geral, para a presença desses serviços. Mesmo sem detalharem sobre a qualidade e disponibilidade deles, os serviços estavam presentes e acessíveis à maior parte dos moradores. A acessibilidade e implantação harmoniosa também podem ser refutadas a partir das pesquisas

\footnotetext{
99 Disponível em: <http://www.folhadamata.com.br/noticia-camara-devera-ouvir-pmv-sobreperda-de-casas-populares-50> Acesso em: 20 jan. 2017
} 
realizadas nos conjuntos e as entrevistas e coletas de dados do presente trabalho. A acessibilidade, na realidade, constitui-se de um dos maiores problemas do conjunto, sendo citada por todos os moradores em algum momento das entrevistas.

A harmonia com os bairros próximos, ou falta dela, mesmo que seja um item subjetivo, pode ser analisada a partir dos relatos que apontam certa desconfiança dos moradores dos bairros vizinhos com relação aos dos conjuntos. Segundo uma das entrevistadas, os comerciantes dos bairros próximos “(...) não tem muita confiança não" (Entrevistada 11, 30 anos, BJC). Nas palavras do entrevistado 12, que já morou no Rio de Janeiro: “ (...) esse bairro aqui ele é considerado lá embaixo uma 'Rocinha'. Quer dizer, um bairro marginalizado" (Entrevistado 12, 66 anos, BJC).

Para a entrevistada 22, quando perguntada sobre a violência no conjunto, revela o que moradores de outros bairros pensariam sobre os conjuntos: "Pela, assim, né, algumas coisas que já aconteceram aqui, aí tem gente que fala: 'Nó, lá aonde você mora é assim, é assado'. Só que eu falo: 'não, até que não'. Às vezes é porque eu moro aqui, né! Assim, eu não acho do jeito que o pessoal acha" E completa: "Mas o pessoal fica bem impressionado mesmo, eles falam mal daqui [risos]" (Entrevistada 22, 25 anos, CSF).

Voltando à questão da participação no processo de implementação, os moradores relatam que foram chamados pela prefeitura para uma reunião de apresentação do Programa e de cada conjunto. A participação, contudo, foi restrita à questionamentos pontuais e não houve espaço para opinar sobre os rumos da implementação dos conjuntos. Tanto a implantação quanto a arquitetura das casas já estavam decididas. O desenho institucional do Programa e as relações entre os agentes envolvidos não permitem que haja participação dos futuros moradores nos processos decisórios, sobretudo na modalidade empresarial. Mesmo no interior das construtoras há pouco espaço para inovações ou estudos mais aprofundados de soluções arquitetônicas e urbanísticas de baixo custo. O tempo é um fator preponderante para a lucratividade do negócio. 
Os agentes envolvidos estão preocupados em cumprir prazos e metas. Logo depois da entrega das casas do conjunto BJC, ainda nos primeiros dias foi relatado o primeiro problema com as novas moradias. Segundo Eliane Guimarães $^{100}$ (relato oral em entrevista), os moradores perceberam que as chaves de algumas casas eram iguais. Ou seja, um morador poderia abrir a porta da casa de outro, o que gerou um desconforto entre os moradores. Ainda segundo a pesquisadora, alguns moradores arcaram com os custos de fechaduras novas, enquanto outros preferiram esperar a troca ser realizada pela construtora responsável, o que atrasou alguns planos de mudança.

Posteriormente, ao decorrer dos anos, problemas como o destelhamento, o aparecimento de rachaduras nos pisos e paredes e o desgaste das pinturas foram outros problemas relatados. Algumas entrevistas e estudos apontam também para o desconforto térmico nas residências. Em parte, isso se deu por modificações já realizadas pelos moradores, como a colocação de cobertura para a garagem, o que gera sombreamento para a área da sala que é contígua à garagem.

Uma das entrevistadas se refere à casa de uma amiga que mora no mesmo conjunto: "eu não gosto de ficar dentro de casa, eu gosto de ficar sentada lá do lado de fora e tem vezes que ela tem coisa pra fazer aí eu pego e venho embora, a casa dela (Figura 28) é muito fria pra ficar lá dentro. [risos]" (Entrevistada 22, 25 anos, CSF). Observa-se que o prolongamento do telhando feito pelos moradores provoca o sombreamento excessivo da residência. Assim, mesmo durante o dia, a sala da casa precisa ficar com a luz acesa.

Muros e "puxadinhos" também foram observados e colaboram na alteração da temperatura interna. Contudo, mesmo nas residências não alteradas, os estudos de conforto térmico e acústico apontam para falhas projetuais e a não obediência à normas, além da inadequação para o desempenho térmico (BORGES, 2013).

\footnotetext{
100 Pesquisadora que acompanhou o processo de implementação dos três conjuntos do PMCMV em Viçosa enquanto cursava mestrado na UFV. Os conjuntos foram seus objetos de estudo para a dissertação.
} 
Figura 28: Garagem de uma das moradoras.

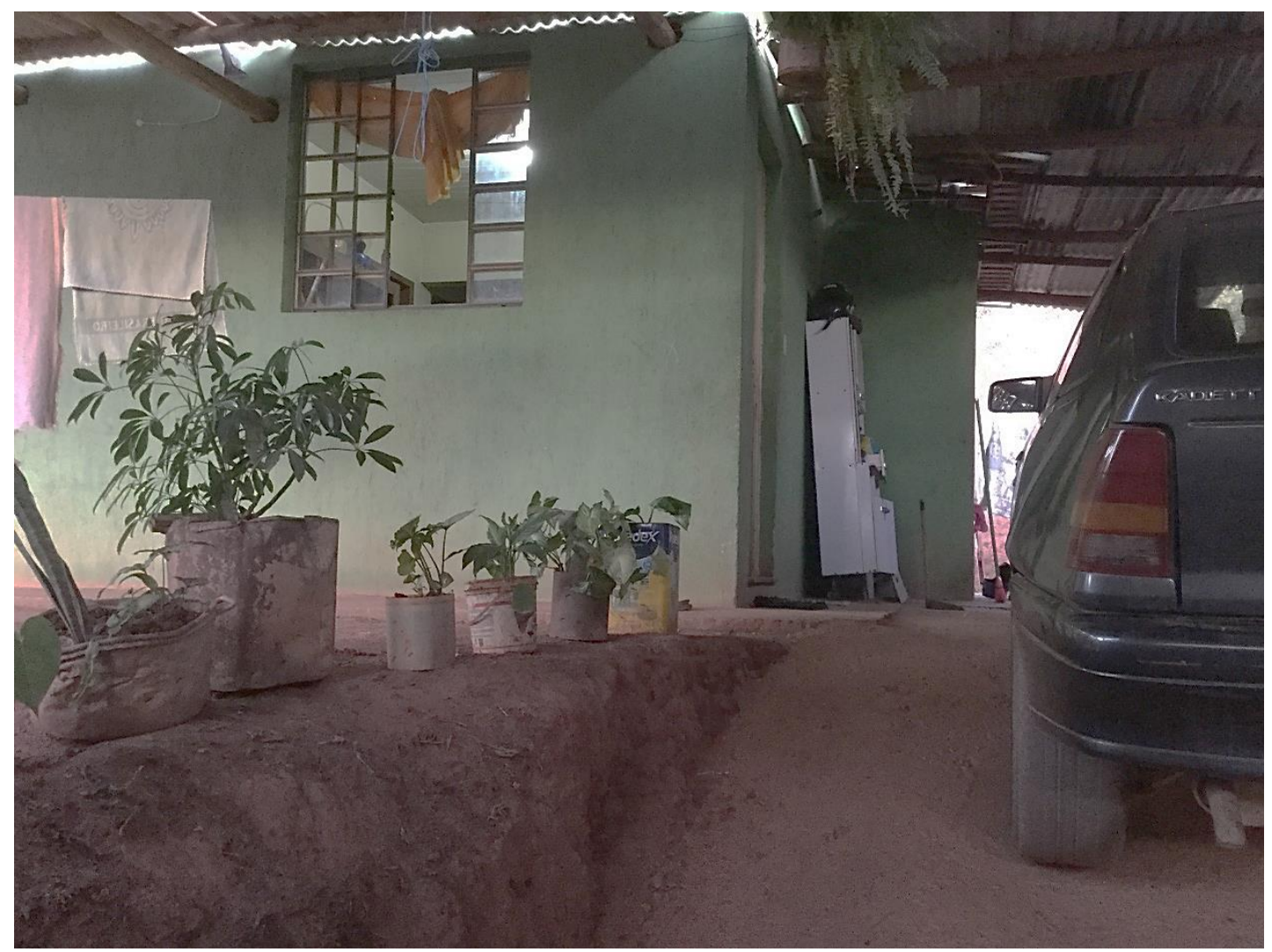

Residência de uma das entrevistadas, onde foram realizadas alterações para cobrir as vagas de garagem e a varanda frontal. Como a residência possui duas vagas cobertas, a proprietária aluga uma vaga para um dos vizinhos.

Fonte: Acervo do autor, 2016.

Percebe-se, a partir das entrevistas, das visitas para coleta de dados e do estudo de Borges (2013) que há uma diferença de conforto térmico entre as casas de um mesmo conjunto, apontando para o erro de implantação das moradias com relação à isolação e ventilação, além dos materiais utilizados e da própria arquitetura que não favorece o conforto. Como afirmou a entrevistada: " $\mathrm{A}$ casa dela é muito fria, ‘num’ tem lógica!” E completa: “(...) aí ela vem e tem vezes que ela fica a tarde inteira aqui, e se eu vou na casa dela eu não consigo ficar meia hora lá dentro" (Entrevistada 22, de 25 anos, moradora do CSF)

\subsection{Os espaços de lazer e as apropriações: desenho urbano, violência e mobilidade}

Alguns meses depois, segundo os moradores, as lixeiras já haviam sido depredadas e/ou retiradas. Em parte, por conta da ineficiência da municipalidade 
em retirar o lixo acumulado, o que gerava mau cheiro para as residências cuja calçada abriga alguma das lixeiras. Dessa forma, os próprios moradores trataram de retirar boa parte das lixeiras, visando evitar que os vizinhos depositassem lixo em frente às suas residências. O acúmulo de lixo, segundo uma das moradoras entrevistadas, resultou também no aparecimento de animais nocivos à saúde:

O lixo é complicado também porque a gente tem que ficar... é duas vezes na semana só que eles tiram. Então, o restante da semana a gente tem que ficar com o lixo na porta. Uma das reclamações piores que a gente tem é isso, porque a gente enfrenta bicho peçonhento dentro de casa. Então assim, é bem complicado pra gente. (Entrevistada 11, de 30 anos, moradora do BJC)

Situação semelhante aconteceu também no conjunto Sol Nascente: "É, porque eles colocavam lixo (...) fora do dia e ficava aquele lixo amontoado, cachorro rasgava... e tinha vezes que aqueles negócio de lixo tava na porta dos outros e aí incomodava" (Entrevistada 22, de 25 anos, moradora do CSF). Ou seja, os elementos de cuidado com o espaço vão se perdendo à medida em que os moradores não veem nos próprios vizinhos e na municipalidade uma contrapartida à altura. Percebem que, em certos aspectos, as soluções devem ser realizadas de forma espontânea e individual, sem auxílio do poder público ou da coletividade.

A depredação também foi observada nos equipamentos de uso público dos dois conjuntos (Figuras 29 e 30). Como parte obrigatória do contrato firmado entre a construtora e a prefeitura, os conjuntos deveriam contar com uma área de lazer para cada um. A intenção da construtora pode ser vista na forma de implantação desses equipamentos. Ambos foram localizados nos limites de cada conjunto, não atentando para uma centralidade que poderia proporcionar maior acessibilidade e visibilidade pelos moradores o que, com isso, poderia gerar maior uso dos equipamentos. Optaram, no entanto, pela implantação na área "restante" de cada conjunto, ou seja, áreas cujo loteamento e construção seria de difícil solução por estarem nas extremidades dos loteamentos e próximos ao curso d'água ou em declive acentuado.

Perguntada sobre o uso dos brinquedos pelas crianças antes da depredação dos mesmos, a entrevistada 13 respondeu: "Vinha! Vinha tudo! O 
parquinho tava completo. Tinha brinquedo, né M. [filha mais nova]? Tinha banco... A gente sentava lá, brincava com as criança... agora, não. Eles rancaram tudo! Destruíram tudo! Aí o mato tomou conta!" (Entrevistada 13, de 47 anos, moradora do BJC). As outras moradoras entrevistadas confirmaram essa informação, apontando para o uso que havia do equipamento nos primeiros meses do conjunto. Um dos moradores relata com certa desconfiança: "Tinha um parquinho, certo? Assim que nós viemos pra cá tinha um parque bem dizer de um condomínio. De dia, com sol quente, ninguém viu que fulano tava com a marreta e tirou o parquinho, tirou o banco, entendeu? Então aquele negócio: 'não sei, não vi'. Poxa!" (Entrevistado 12, de 66 anos, BJC). De acordo com as entrevistas, percebemos um pacto de silêncio entre os moradores com relação a esses equipamentos e mobiliários urbanos. Indiretamente, induzem a pensar que a depredação foi obra de pessoas ligadas ao tráfico de drogas; algumas delas moradoras dos conjuntos, mesmo.

Figura 29: Acesso à praça do Conjunto Sol Nascente.

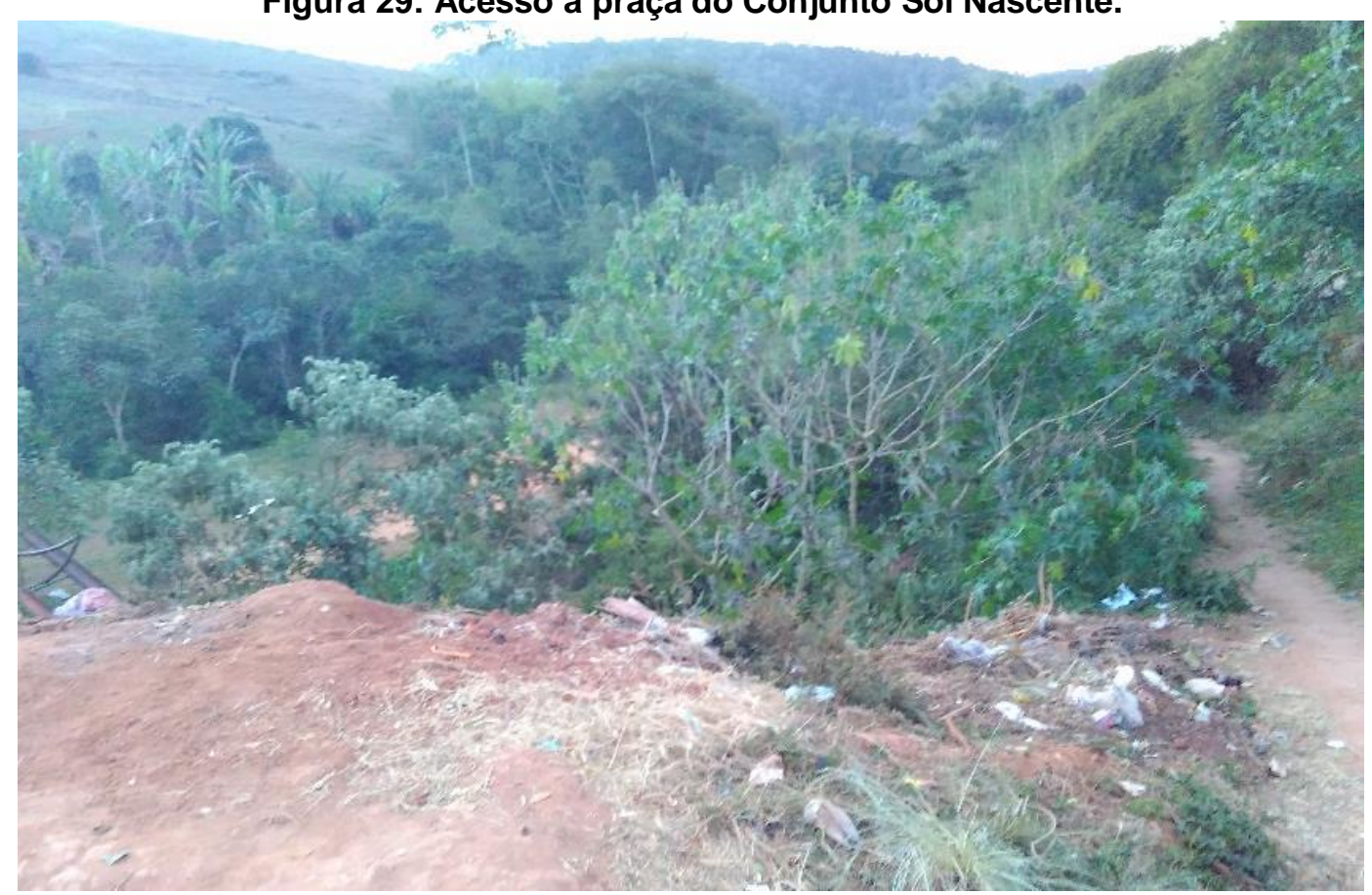

À direita, trilha de acesso à Praça do CSF. A praça foi transformada em um campo de futebol. Atualmente, poucas pessoas fazem uso do local e ele passou a ser evitado pelas famílias. Fonte: Acervo do autor, 2016

Por outro lado, o auxílio incerto e apenas esporádico que a municipalidade presta na manutenção dos espaços comuns incita comportamentos de cuidado com esses espaços. Ainda segundo a entrevistada 13 a capina da pracinha é 
feita "de vez em quando" pela prefeitura e que "os moradores de vez em quando capina. Quando a prefeitura não manda limpar, os moradores mesmo começa a limpa." (Entrevistada 13, de 47 anos, moradora do BJC). A entrevistada 14 relata algo semelhante: "É, é a gente mesmo que poda as árvores aqui, de vez em quando. Essa árvore minha mesmo tá precisando de podar. Meu menino, mesmo, poda. Arruma umas ferramenta aqui, que nem as ferramentas a gente tem, não. A gente toma dos vizinho emprestado" (Entrevistada 14, de 47 anos, moradora do BJC)

A partir dos relatos sobre os usos e a depredação dos mobiliários e equipamentos públicos, podemos perceber a influência do desenho urbano dos conjuntos na falta de uso e controle popular dos espaços. Os brinquedos foram colocados de lado pelos moradores, que preferiam maior espaço gramado para outras atividades que não o uso dos brinquedos.

Figura 30: Praça do Conjunto Coelhas em 2015.

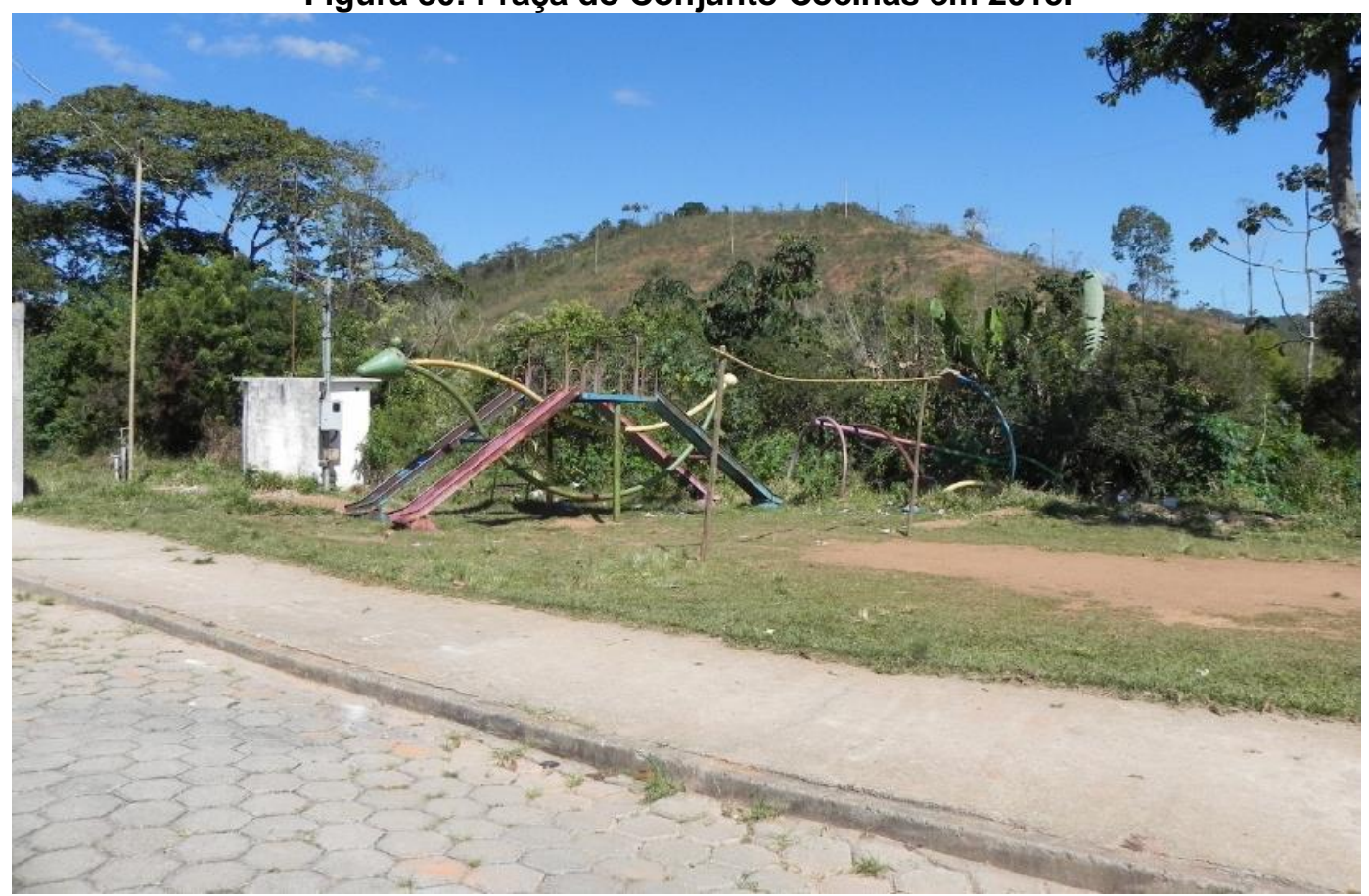

Vê-se que os brinquedos estão colocados um sobre o outro, inutilizáveis. Havia ainda traves de bambu para configurar um campo de futebol. As traves foram posteriormente retiradas. Fonte: Acervo do autor, 2015

Em pouco tempo, sem usos constantes, as praças foram tomadas pelo mato e alguns entulhos, como podemos observar na Figura 30. Sem os "olhos 
das ruas" (JACOBS, 2011), as pracinhas e os brinquedos que nelas estavam foram, aos poucos, sendo abandonados e depredados.

Os urbanistas parecem não perceber quão grande é a quantidade de adultos necessária para cuidar de crianças brincando. Parecem também não entender que espaço e equipamentos não cuidam de crianças. Estes podem ser complementos úteis, mas só pessoas cuidam de crianças e as incorporam à sociedade civilizada. (JACOBS, 2011, p. 89)

Não apenas o público infantil, mas mesmo os adultos utilizavam os espaços das praças, sobretudo do conjunto BJC, o Coelhas, onde a praça tem uma localização mais próxima e visível a todos c em relação à localização da praça do conjunto CSF. No caso deste último, sua praça parece ter sido muito pouco usada pela população em geral. A praça está em um nível abaixo do da rua de chegada, e seu acesso é dificultado por uma descida íngreme em um trecho de terra batida. Para chegar à praça, neste caso, deve-se percorrer essa decida por cerca de 30 metros. Sua implantação é limítrofe a apenas duas residências e mesmo essas não têm visibilidade para a praça, devido à vegetação interposta entre as casas e a praça. Dessa forma, a praça é praticamente ignorada pela população local. De todas as visitas realizadas, em nenhuma havia presença de alguém na localidade. Ademais, as moradoras entrevistadas também relatam a inutilidade do espaço como para o descanso e o lazer.

Os moradores do conjunto CSF, o Sol Nascente, têm como opções de atividades um bar que se localiza na entrada principal do lugar e uma Igreja (de São Francisco de Assis) recém construída, que fica entre os dois conjuntos estudados, facilitando o acesso dos moradores de ambos os lados. Sem a praça, os moradores do CSF se utilizam das calçadas e ruas paralelas à principal, pois esta tem movimento maior de veículos. A rua principal é também desagradável para a permanência nas calçadas pela poeira instalada em determinadas épocas do ano, visto que um dos acessos a ela é uma estrada de terra.

Como relatam duas das moradoras (Entrevistadas 21 e 22), suas eventuais caminhadas acontecem no início da noite e não incluem a praça. $O$ 
período escolhido deve-se ao marido da entrevistada 21, pois é quando ele chega do trabalho e pode cuidar dos filhos pequenos. O percurso escolhido pelas moradoras passa pela rua de maior movimento e percorre o trecho asfaltado que liga os dois conjuntos do Bairro São Francisco de Assis. As moradoras reclamam da falta de iluminação pública no trecho de asfalto.

As famílias que viviam em coabitação revelaram-se como as que mantinham melhor relação com a antiga moradia. Duas dessas três famílias também se apresentaram como as que sentem mais falta do antigo local de moradia e das relações sociais estabelecidas a partir da moradia. Nesses casos, as pessoas entrevistadas destacam, sobretudo, a proximidade da moradia com os locais que mais frequentavam. Uma das entrevistadas destaca que, apesar do pouco espaço para seu núcleo familiar dividir com a avó e outros familiares, a casa era "boa". E completa: "Ah, eu gostava do bairro. Era tudo mais perto, né? O Centro. Aqui é tudo um pouco mais longe, então..." (Entrevistada 11, de 30 anos, moradora do CSF)

Observamos que para essa moradora a qualidade da moradia extrapola os limites da habitação. Para ela a casa era "boa" pois ficava perto de "tudo". Assim, podemos compreender também suas reclamações quanto aos espaços do conjunto para desenvolver atividades de lazer e descanso junto à sua família. Segundo ela, antes de se mudarem para o MCMV, sua família costumava realizar passeios nos "parques" da cidade, quais sejam, a UFV e o Parque do Cristo: "Antigamente dava pra ir. Hoje eu não sei se dá porque tem muito tempo que eu vim pra cá então fica mais longe. O mais é só ir no Centro mesmo, que a gente vai de vez em quando" (Entrevistada 11, de 30 anos, moradora do CSF)

As possibilidades de espaços para usos e apropriações para a entrevistada, portanto, se restringiram depois de sua mudança para o conjunto. Tendo em vista que a sua família possui veículo próprio, a moradora revela que ocasionalmente consegue ir ao centro da cidade. Como ela explica, a alternativa mais próxima de lazer fica na Praça do Rosário (Figura 31), onde se encontram, nos finais de semana, atividades e comércio voltadas à diversos públicos, incluindo o infantil, com a presença de brinquedos, carrinhos de pipoca, cachorro 
quente e etc.: "É, na praça porque tem os brinquedos. Não é sempre também, não. Mas quando pode, a gente vai" E completa, mostrando as limitações nas opções de lazer causadas pelos problemas relativos também ao tempo, devido ao cotidiano de trabalho em períodos prolongados que o marido taxista faz e à jornada dupla de mãe e empregada doméstica que ela realiza:

Assim, a gente tinha um parque, né? Só que aí eles acabaram danificando tudo e não tem mais. $E$ mais no final de semana mesmo a gente fica em casa, porque meu marido trabalha a noite, né! Ele é taxista. Eu trabalho de dia e ele de noite. Então, assim, acaba que não tem muito lazer, não. Quando pode é raríssimo. É raridade! (Entrevistada 11, de 30 anos, moradora do CSF)

Figura 31: Feira de artesanato na Praça do Rosário, centro da cidade.

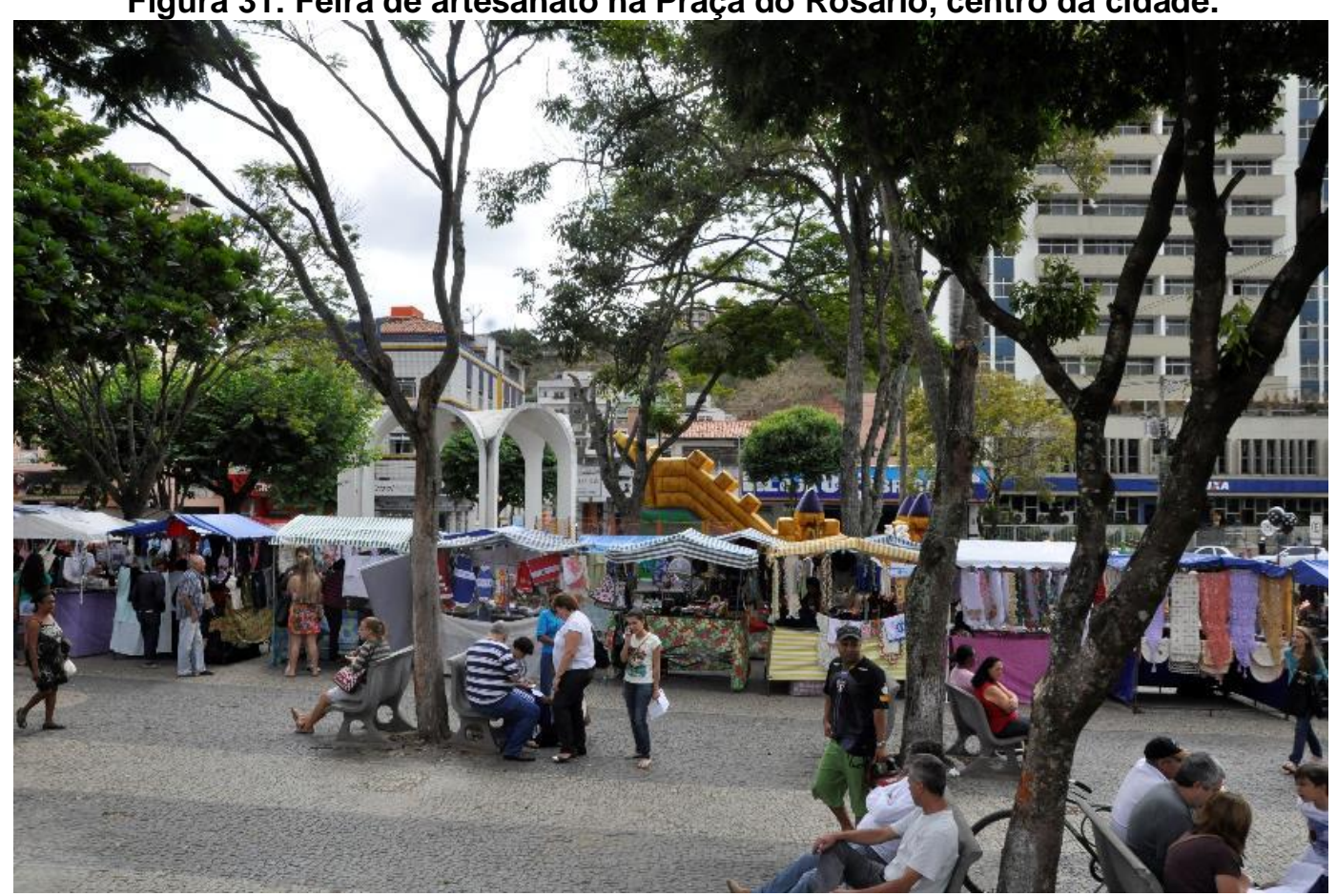

A feira ocorre aos sábados e conta com espaço destinado ao público infantil, como podemos observar um escorregador inflável amarelo, no centro da imagem.

Fonte: <http://www.com.ufv.br/caixapreta/wp-content/uploads/2014/05/DSC0008-2.jpg> Acesso em: 20 ago. 2016.

As outras famílias que possuem veículo próprio são também as que tem maior raio de ação na cidade, relatando idas diárias e/ou ocasionais ao centro e a outros bairros para além do Santa Clara. Segundo um dos entrevistados, suas atividades mais comuns se dão no Centro da cidade, mas também faz visitas esporádicas a amigos que moram no Bairro Bom Jesus e no São Sebastião, 
além do próprio Centro. Ele revela com isso, então, que tem certa mobilidade para sair do conjunto quando desejar ou precisar.

Para essas duas famílias, o raio das distâncias comuns para suas atividades profissionais e de lazer chega a mais de 4 quilômetros, enquanto as outras famílias relatam percorrer distancias não maiores do que 2 quilômetros em suas rotinas. Cabe lembrar que o acesso mais próximo do conjunto BJC dista cerca de 500 metros do bairro mais próximo, o Santa Clara. Já uma outra moradora do Sol Nascente (Entrevistada 21) revela que, mesmo sua família tendo veículo próprio, suas idas a outros bairros e localidade são poucas, pois o veículo que poderia ser utilizado pela família está com os documentos vencidos.

Dentre os problemas com maior frequência e ênfase nos relatos, destacase a mobilidade urbana. O problema viários de acessos aos conjuntos somamse com os poucos horários de ônibus disponíveis e com a falta de modais alternativos para deslocamentos. Devemos lembrar que o conjunto fica em um pequeno vale, sendo o acesso ao Centro e à maior parte da cidade por meio de uma rua de inclinação acentuada e de calçamento que era, até o momento das entrevistas, de pedra fincada, tornando difícil a mobilidade por bicicleta ou a pé. Faltando cerca de dois meses para as eleições municipais, a prefeitura realizou o asfaltamento do morro de acesso aos conjuntos.

Durante as visitas ao conjunto, notamos a circulação de táxis em uma frequência que chegou a 4 táxis por hora em um dos conjuntos, que tem 132 habitações. Uma frequência alta tendo em vista a densidade habitacional e populacional dos conjuntos. Contudo, os horários de coleta de dados foram diurnos e pouco se estenderam durante a noite, período no qual, segundo os moradores, os taxistas evitam trafegar na localidade, até mesmo negando a prestação de serviço para os moradores dos conjuntos: "Asfalto que não tem. Difícil pra gente posto de saúde, difícil pra gente ir pra escola. Lotação é difícil. Tudo aqui... tudo aqui é difícil. Se ligar prum táxi e pedir pra vir buscar você aqui, não é todos que vem, não" (Entrevistada 13, 47 anos, BJC)

Como já citado, os horários de ônibus são poucos e se concentram em períodos de ida e volta do trabalho, ou seja, há maior disponibilidade de 
transporte coletivo no início da manhã, no horário de almoço e no final da tarde. No período noturno e nos finais de semana o transporte público é ainda mais escasso, limitando as possibilidades de passeios e até mesmo de trabalhos nesses períodos para os moradores. Segundo Carvalho (et al, 2015, s/p), contando serviços como posto de saúde, creches, espaços de lazer e de trabalho, apenas o acesso à escola tem avaliação positiva para mais da metade dos moradores.

Ressalta-se que há transporte escolar gratuito para levar os alunos dos conjuntos às escolas mais próximas, o que pode ter influenciado nas respostas dos entrevistados. Cabe destacar também que mesmo esse serviço tinha sua realização dependente das condições climáticas, pois em épocas de muita chuva o ônibus não conseguia subir a rua de pedra fincada, realidade que durou até aproximadamente setembro de 2016.

Aos poucos, novas atividades com um novo público ocupou o lugar dos brinquedos, afastando as crianças desses locais e, em consequência, afastando também os adultos responsáveis por elas. Em 2015 ainda havia restos dos brinquedos em um canto da pracinha do conjunto Coelhas (Figura 32). A pracinha havia sido transformada em um pequeno campo de futebol $\mathrm{e}$ atualmente não se vê nem os brinquedos nem as traves do campo de futebol. Há apenas grama e lixo e, em épocas de vento (junho, julho e agosto), a praça é usada como local para a produção e secagem de cerol ${ }^{101}$ para as pipas, principal atividade de crianças e jovens do Coelhas para as horas de descanso e lazer.

Mesmo as pipas não são bem-vindas na pracinha do conjunto Coelhas, pois o uso da praça é escasso e restrito apenas a jovens e adultos que não permitem o compartilhamento com as crianças do conjunto. Restou às crianças e à parte dos adolescentes a tentativa de utilizar a rua e um terreno baldio ao lado do conjunto, local propício para disputas de pipa com moradores dos bairros vizinhos (Figura 33 e Mapa das Áreas de Lazer, em anexo).

${ }^{101}$ Composto artesanal de pó de vidro e cola, passado na linha da pipa para cortar as linhas de outras pipas em disputas entre as crianças e adolescentes de um bairro contra as de outro. 
Figura 32: Praça do Conjunto Coelhas em 2016.

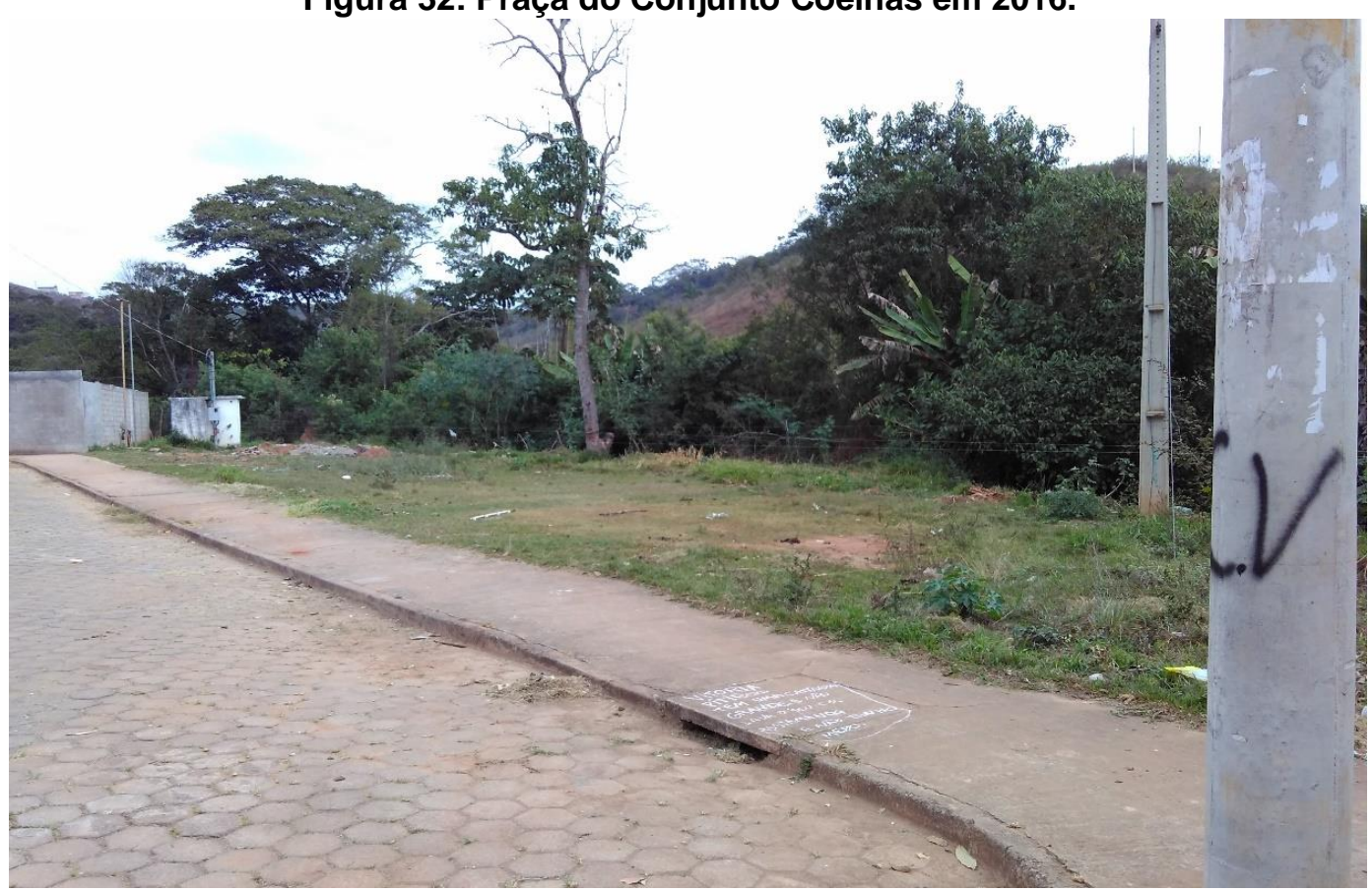

Ao fundo, à esquerda, vê-se uma pequena concentração de entulho de obra, provavelmente restante da construção do muro da casa ao lado. À direita, um poste com a inscrição CV (Comando Vermelho), em alusão à facção do crime organizado. Ao centro, inscrições com giz branco sobre um bueiro com um recado difamatório sobre alguém; está assinado como "Amanda e não tenho medo".

Fonte: Acervo do autor, 2016

Figura 33: Criança brincando de pipa no terreno baldio.

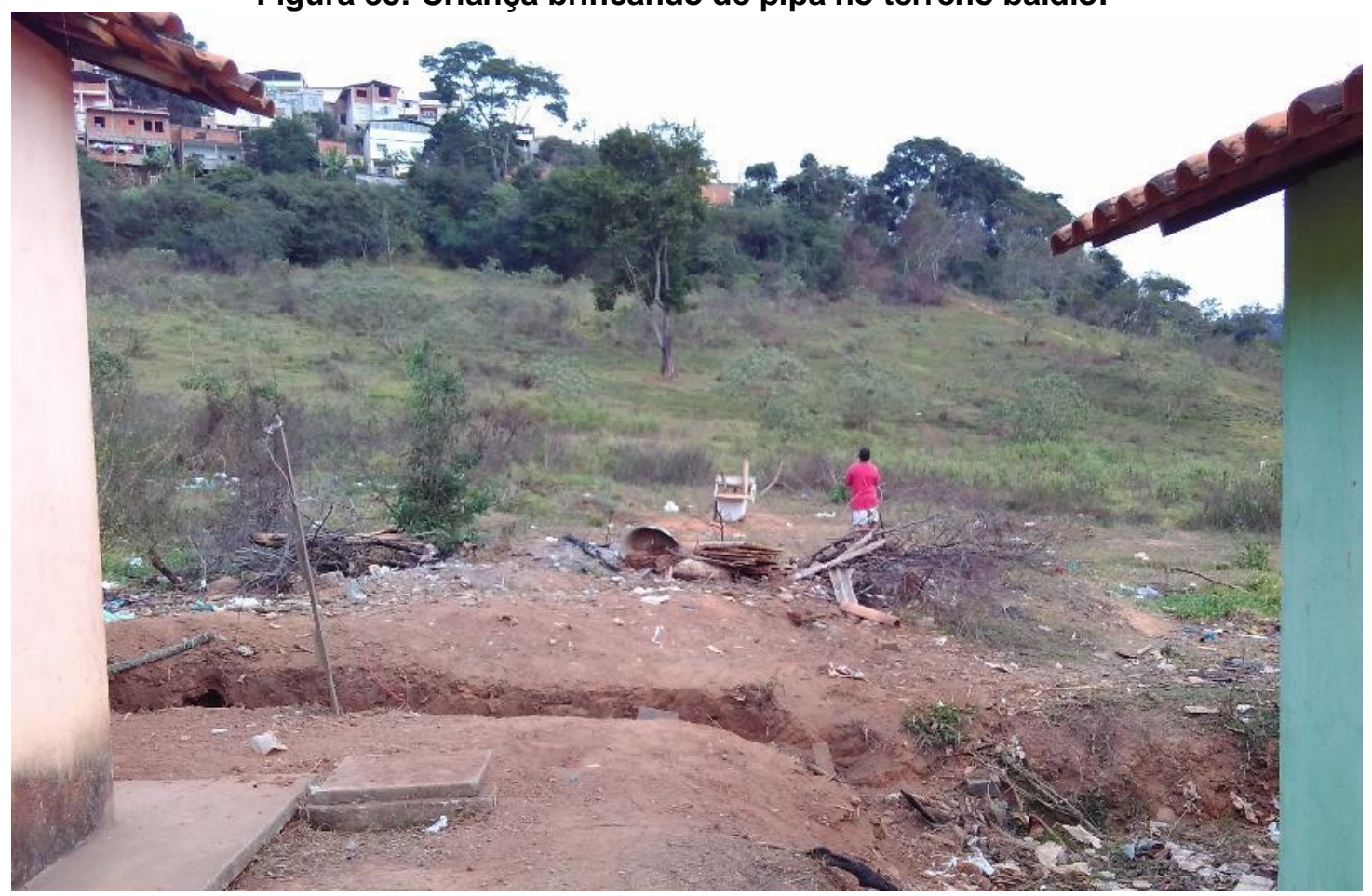

Fonte: Acervo do autor, 2015. 
Já nos espaços das ruas, de acordo com a idade, é comum ver a população infanto-juvenil andando de bicicleta e jogando bola, sobretudo em finais de semana. As calçadas são ocupadas por crianças mais jovens e em dias de semana, próximos às casas de algum ou alguns dos pais e mães. As atividades são realizadas no período entre o início e o final da tarde, não avançando muito a partir das 17 horas em nenhum dos dias nos quais foram realizadas as visitas. Segundo a esposa de um dos moradores (entrevistado 12, 66 anos, BJC), que acompanhava parte da entrevista com o marido, a partir das 18 horas há uma espécie de "toque de recolher" que mantém os moradores em suas casas: "Chegou seis horas, portão trancado"

As questões relativas às crianças são de suma importância nas sociabilidades, apropriações e desejos de permanência nos conjuntos. Observamos que elas são o grupo que mais utiliza os espaços públicos, sobretudo no período de férias escolares, período em que foi feita a primeira coleta de dados no campo. Mesmo os adultos regulam suas ações nos espaços públicos a partir das atividades de seus filhos, saindo à calçada para vigiá-los em suas brincadeiras ou acompanhando-os em passeios aos locais de lazer, dentro e fora do conjunto. É comum vermos duas mães de crianças conversando encostadas no portão de uma casa enquanto olham as crianças.

A população infantil é também a catalizadora de sociabilidades pontuais, que não se configuram como relações de amizade. A entrevistada 22 é um exemplo disso. Segundo ela, há um pequeno grupo de amizades estabelecidas no conjunto, mas que se construíram antes da mudança para o MCMV, quando moravam no mesmo bairro, sobretudo:

(...) as amizades que eu tenho, que eu frequento são aquelas amizades que eu já tinha quando eu morava lá em cima e que também vieram pra cá, entende? Enquanto esses vizinhos assim, tipo assim, eu conheci aqui, entende? Aí já não tem muito assunto. E também eu não gosto que vizinho fica vindo muito na minha casa, não. Prefiro mais, assim, as amizades que eu já tinha antes, entendeu? (Entrevistada 22, de 25 anos, moradora do CSF)

A mesma moradora, por outro lado, conta com a solidariedade de vizinhos próximos, principalmente a vizinha que mora em frente à sua casa, mesmo não 
descrevendo sua relação com ela como de amizade. Essa solidariedade se dá quando a entrevistada precisa se ausentar em horário não-escolar, ou seja, quando seus filhos estão em casas. Nas entrevistas, outras moradoras relatam que contam com a eventual ajuda de alguma vizinha para cuidar de seus filhos enquanto trabalham fora. Ou ainda, trocam esse tipo de favor, alternando e compensando uma a outra de acordo com as necessidades de ausência, pois, como frisado pela entrevistada 22 (25 anos, moradora do CSF): "(...) a condição dela é igual à minha”. As sociabilidades, então, também se configuram como estratégias de sobrevivência. Sem creches e/ou escolas de tempo integral para as crianças, elas acabam se tornando motivo para a perda de um dia de trabalho, sobretudo para as mães solteiras ou cujo parceiro trabalha fora.

Assim, igual tem a vizinha da frente ela, assim, ela tem dois
meninos pequenos. Aí tem dias que ela precisa ir pra rua, aí, pra
ela não ter que levar os dois, eu falo pra ela se ela precisar ela
pode deixar, né? Assim, a que é um pouco mais velha, que o
bebezinho dela, comigo, porque ela anda muito pouco, e a
condição dela também é quase igual à minha. Aí, assim, tem
vezes que eu fico com a menininha pra ela, ou quando ela 'tá'
apertada lavando roupa e eu escuto o bebê chorando, aí tem
vezes que eu pergunto pra ela se eu posso trazer o bebê pra cá
e ela vai e deixa, já ajuda ela... Tem vezes quando eu preciso
sair, também, eu deixo os meus aqui em casa que a minha de 9
anos já toma conta dos outros dois, né? Aí eu tranco a casa e
deixo eles e peço ela pra dar uma olhada, assim, se acaso
alguém chamar (Entrevistada 22, de 25 anos, moradora do CSF,
grifos nossos)

Outros tipos de auxílio mútuo também foram relatados. Segundo uma entrevistada do conjunto BJC (13, 47 anos), as ajudas são "frequentes" e os laços de solidariedade estão presentes em todo o conjunto. $O$ imóvel que esta moradora ocupa (ela não é a proprietária e não paga aluguel) estava vazio e depredado. Do imóvel foram tirados os equipamentos hidráulicos, lâmpadas, fios e etc: "É! Ficou largada. Não tinha porta. Não tinha vaso. Não tinha pia no banheiro. Nada! Eles tiraram tudo. Tava só o 'oco'! Só as paredes e o telhado. Só a caixa d'água que eles num levaram! É, aí um me doou o vaso. Outro me doou a pia. Foi me doando uma porta... Cheguei aqui num tinha era nada!"

Outras formas de sociabilidade foram encontradas esporadicamente no conjunto. Conversas entre vizinhos nas calçadas, no comércio do conjunto Coelhas (BJC) e no bar na entrada do conjunto Sol Nascente (CSF). Não é raro 
vizinhos que estão de passagem pararem para alguma conversa rápida com outro vizinho que está na janela da casa ou junto ao portão. Outro local de sociabilidades de cordialidade são os pontos de ônibus e o próprio ônibus, onde conversas podem se estender durante o trajeto de ida ao trabalho, por exemplo.

Observamos como fator importante de sociabilidades nos conjuntos a presença cotidiana de Igrejas e ONG. Em entrevista com uma das ex-moradoras dos "predinhos", ela relata a importância do auxílio de moradores das proximidades e de instituições filantrópicas, com destaque para a "Conferência", entidade ligada à Associação São Vicente de Paula que, por sua vez, tem ligações com a Igreja Católica. Essa entidade proveu auxílios à esta família mesmo depois da mudança para o conjunto BJC, deixando de ajuda-los após algum tempo, segundo a moradora, por terem entendido que a família "soube se virar muito bem" (entrevistada 14, 47 anos, BJC).

Observamos, então, a presença de ONG e de lgrejas prestando assistência a algumas das famílias e intermediando trabalhos, festividades e sociabilidades. Além da Conferência, que auxilia com a doação de mantimentos e roupas para as famílias em situação mais vulnerável, há também a Casa do Caminho, uma instituição filantrópica que acolhe pessoas alcoólatras e suas famílias, encaminhando para internação quando necessário. Além disso, segundo relatam moradoras, a Casa do Caminho também auxilia famílias doando materiais de construção e outros itens visando a melhoria do ambiente doméstico. Nesta instituição, os frequentadores podem aprender a fazer itens de artesanato que são vendidos pela instituição: "Aí eles vendem e tem um por cento da gente e tem o deles, né! Mas dá pra tirar alguma coisa" (entrevistada 22, 25 anos, CSF).

Em outra entrevista, a moradora faz questão de mostrar alguns dos trabalhos de artesanato (Figura 34) realizada por ela também na Casa do Caminho. Segundo relatam, conseguem o material para 0 artesanato na instituição e o levam para casa, onde realizam o trabalho: "Eu trago pra cá. Eu faço tapete. Esses quadro ali, ó [apontando para a parede ao lado da estante] 
que a gente fez. Algum porta-retratos, almofada, algumas bolsa... tem até umas bolsa aí e umas almofada. Você interessa ver?" (entrevistada 14, 47 anos, BJC).

Figura 34: Interior da residência da entrevistada 14.

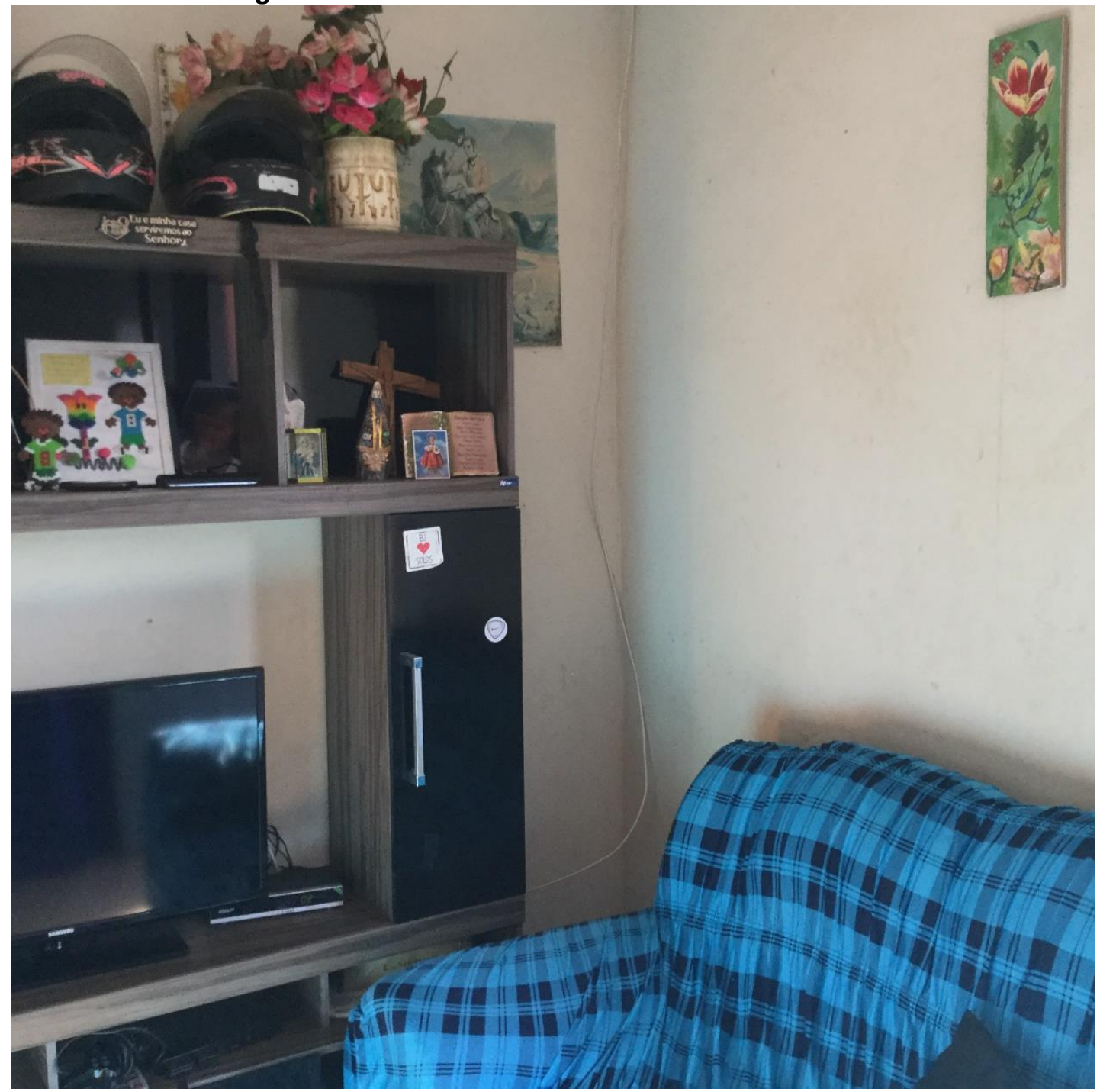

Observa-se a presença de itens artesanais feitos pela moradora. São eles um dos quadros na parede, logo acima do sofá, e o porta-retratos na estante. Além desses itens havia almofadas decoradas sobre os sofás.

Fonte: Acervo do autor, 2016

As Igrejas têm presença nos conjuntos não apenas através de instituições ligadas a elas. Segundo os moradores, igrejas evangélicas promovem cultos nas casas de alguns dos moradores. Há no conjunto BJC uma Pastora que organiza esse tipo de encontro. Ela foi também a responsável por promover uma festividade para o Dia das Crianças em 2015, segundo o entrevistado 12 (66 anos, BJC). Essa relação entre uma instituição religiosa e a festividade em questão foi relatada pelo mesmo morador: "A vizinha lá da frente, ela deu sorte. 
Ela fez uma Igreja Adventista Do Sétimo Dia. É adventista? É Adventista Do Sétimo Dia, isso. Então tem muita criança, certo? Então ela deu sorte porque a igreja tá funcionando, eles já... esse mês eles conseguiram fazer um retiro, as crianças colaboraram vendendo bombom, tudo, fizeram bonitinho." (Entrevistado 12, 66 anos, BJC).

A Igreja Católica também promoveu atividades, mas relacionadas ao dia de São Francisco de Assis, Santo cuja igreja construída entre os conjuntos é devota e dá nome ao bairro. Segundo a moradora 22 (25 anos, CSF), a Igreja é um dos locais de encontro e sociabilidades dos moradores dos dois conjuntos. As missas são realizadas nos finais de semana: "É, assim, quando tem uma missa de domingo, assim, costumo ir. É, quando tem a missa de São Francisco, aí meu menino veste de São Francisco. Essas coisas assim". A mesma entrevistada completa dizendo: "(...) geralmente eles levam as crianças lá na estrada de chão, numa casa lá, aí saí dali e vem caminhando e cantando até na igreja. Tem vezes quando é uma procissão, assim, também eles saem lá do conjunto de lá e dá uma volta no conjunto lá e vem aqui na igreja".

Ainda segundo a mesma moradora, há também procissão de outras santidades, como a de Nossa Senhora Aparecida, às quais participam os moradores. A entrevistada revela que vai pouco à missa e que não se declara de alguma religião específica, apenas gosta de acompanhar missas e cultos: "Ah, sei lá, acho que eu sou ateu. É, porque, tipo assim, eu gosto é de ir na igreja evangélica, eu adoro os cultos, muito bom. Mas, assim, tem vezes que pelo meus meninos, né, eu gosto de levar às vezes na missa, entende? Mas é muito raro também. Mas é mais a igreja evangélica que eu frequento" (Entrevistada 22, 25 anos, CSF).

Podemos ponderar sobre essa fala e as demais sobre a importância das igrejas como intermediadoras de sociabilidades nos conjuntos. Sem as igrejas, as festividades e outras atividades de encontros seriam ainda mais escassas. Ademais, relações sociais são estabelecidas a partir das missas e cultos, bem como o envolvimento coletivo na participação nessas atividades, como visto para a procissão de São Francisco de Assis. 
Outras festividades e atividades coletivas são organizadas pelos próprios moradores, como bazares e festas juninas. Contudo, segundo as entrevistas, a frequência dessas atividades vem sendo cada vez mais baixa. A municipalidade também realiza eventos nos conjuntos, com destaque para uma sequência de shows musicais que percorre alguns bairros da cidade. Os shows nos conjuntos tiveram pouca frequência de moradores na sexta, primeiro dia do evento. No sábado, segundo e último dia, segundo relata o entrevistado 12 (66anos, BJC), a prefeitura não dispôs de verba para pagar a banda contratada e o show foi cancelado já perto do horário de acontecer. Ao final, o evento "Num deu muita coisa, certo? Num deu ibope" (Entrevistado 12, 66anos, BJC). A filha mais nova da entrevistada 13, que acompanhava a conversa, aponta que a prefeitura chegou a promover uma festa junina, ao que a entrevistada completa que: "Foi com a ajuda dos moradores que teve essa, né?! Dos moradores com a prefeitura que teve essa festa junina". Ademais, a municipalidade organizou pequenas ações esportivas e de Natal ao longo dos primeiros anos dos conjuntos, sem muito destaque, contudo.

\subsection{Violência como fator limitador de apropriações e da liberdade de ação}

Poucos meses após a "inauguração" do conjunto Coelhas (BJC), a localidade já apresentava sinais de controle do tráfico de drogas. À época da construção do conjunto Sol Nascente (CSF), o tráfico de drogas já estava instalado na região, sob o controle das organizações que "controlam" o bairro Santa Clara, conforme informações adquiridas junto a um Policial Militar. A sensação de violência e o convívio com pessoas ligadas ao tráfico, além de casos eventuais de furto em residências, constroem uma percepção de perigo para alguns dos moradores.

Apesar de aparentemente contraditórios, dois dos temas que apareceram com maior destaque nas entrevistas com relação aos conjuntos foram "tranquilidade" e "violência". Há, certamente, o conflito entre os temas quando são expressados pelas mesmas pessoas e se referindo a uma mesma 
localidade. Devemos, então, buscar compreender quais aspectos compõe essa "tranquilidade" e quais aspectos compõe a "violência" e o "perigo" expressados.

A tranquilidade, como podemos observar nas entrevistas, está primeiramente relacionada com a liberdade de uso do espaço de suas residências. Isso se dá, pois, a situação anterior de moradia se caracterizava pela coabitação, ou pela precariedade ou eram alugadas, retirando a liberdade de possibilidades de usos, de modificações e adaptações às suas necessidades e desejos. A propriedade, portanto, vem acompanhada de maior liberdade de ação das famílias no ambiente doméstico. Essa liberdade está ligada também ao fator da intimidade, tendo em vista que algumas das famílias viviam em coabitação, o MCMV apresenta a essas famílias a possibilidade de desenvolverem um ambiente familiar íntimo. Outro fator ligado à tranquilidade é uma espécie de acordo não-verbalizado entre os vizinhos de não se envolverem uns com os outros, algo presente em algumas das entrevistas:

Porque antes era assim: só encostava [a porta], né! Encostava, fechava a porta e punha um cabo de vassoura atrás e saía. Saía com aquele medo danado! Mas na época a gente não tinha muita coisa pra ninguém mexer, não. Então nós não esquentava a cabeça, não! Agora... agora eu já me sinto mais segura aqui dentro de casa. Eu me sinto mais segura porque os vizinho aqui, ninguém mexe em coisa de ninguém. Ninguém prejudica ninguém, não (Entrevistada 14, 47 anos, BJC)

As contradições quanto à tranquilidade e à segurança continuam em outras entrevistas. Segundo a entrevistada 11 (30 anos, BJC), houve um período no qual a linha de ônibus operava até as 22 horas, mas que isso foi "cortado" pois houve casos de assalto dentro do veículo quando passava por trechos menos povoados da cidade: "Falaram: 'não, não tem como ir'. De noite, né? Se for avaliar bem, ninguém quer colocar sua vida em risco". Ao responder à pergunta seguinte na entrevista, a mesma moradora afirma que: "Não tenho o que reclamar não. É bom. O pessoal é bom. Claro que cada um tem sua restrição, né? Cada um vive por si, mas não é um lugar ruim de se viver não. Mas se fosse pra mim escolher, hoje eu não ficaria. Não ficaria"

A partir dessa fala e de outras dos moradores entrevistados, podemos perceber que há um respeito à individualidade mesclado também a um distanciamento preventivo com relação ao coletivo, tendo em vista que o 
envolvimento poder gerar problemas aos moradores, como foi o caso da moradora supracitada. Segundo ela, seu marido levou um tiro no quadril ao tentar separar uma briga na rua e que, depois disso, sua família prefere não se envolver: "(...) Porque como é um lugar complicado, como eu te falei, é melhor cada um na sua" (Entrevistada 11, 30 anos, BJC)

A entrevistada 11 revelou também que a falta de espaços para as crianças brincarem motivou uma tentativa de retomada da praça do conjunto, onde se encontravam os brinquedos:

A gente tentou reerguer ele de novo porque tinha sobrado
algumas coisas, aí o pessoal lá de baixo [Conjunto Sol Nascente]
tiveram o parquinho deles destruído também e tentaram doar
alguma coisa de lá de baixo também pra fazer em conjunto com
gente pra trazer as crianças tudo aqui pra cima. Mas não teve
jeito. Eles não deixa. Eles não deixa, destróitudo. A gente fizemo
no sábado, no facebook, tudo direitinho. A gente conseguiu que
outras pessoas de lá de cima mesmo deram pra gente fazer. Não
ficou. Eles acaba arrancando. (Entrevistada 11, de 30 anos,
moradora do Coelha)

A entrevistada revela ainda que não sabe claramente quais os motivos dessa disputa territorial pelo espaço da antiga praça dos brinquedos, tendo em vista que as atividades ilícitas não ocorrem exatamente ali, pois no lugar "não dá pra fazer nada [de ilícito] porque todo mundo tá vendo. Não é um lugar escondido nem nada, mas parece que não quer, então..." (Entrevistada 11, de 30 anos, moradora do Coelha). A partir das observações realizadas no local, averiguamos que os espaços das praças dos conjuntos permanecem a maior parte do tempo vazios, sem qualquer uso, nem mesmo o de vigilância. Devemos levar em consideração, não obstante, que a praça é o único espaço público de cada conjunto. O domínio desse espaço pode significar o domínio territorial do conjunto. Ademais, sem a alternativa de uso desses espaços, os moradores ficam cada vez mais restritos ao uso apenas de suas residências e, em determinados horários, das ruas e calçadas próximas de suas residências.

Há diversas pichações nos conjuntos, sobretudo no Coelhas (BJC), que indicam a presença do tráfico de drogas nas áreas aqui estudadas (Figura 35). No muro mostrado na figura encontram-se frases como "PM bom é PM mo[r]to" e siglas das facções criminosas mais conhecidas no Brasil: o PCC (Primeiro 
Comando da Capital) e o CV (Comando Vermelho). Além dessas, há a sigla BDC que significa Bonde das Casinhas, indicando que há ali uma organização própria. Contudo, segundo levantado com um membro da Polícia Militar da cidade, o bairro Santa Clara e imediações não tem segmentos dessas facções, assim como o restante da cidade. Mesmo que haja divisões territoriais entre diferentes traficantes, as disputas se restringem ao cenário local da região.

Figura 35: Muro de uma das residências do Conjunto BJC, o Coelhas.

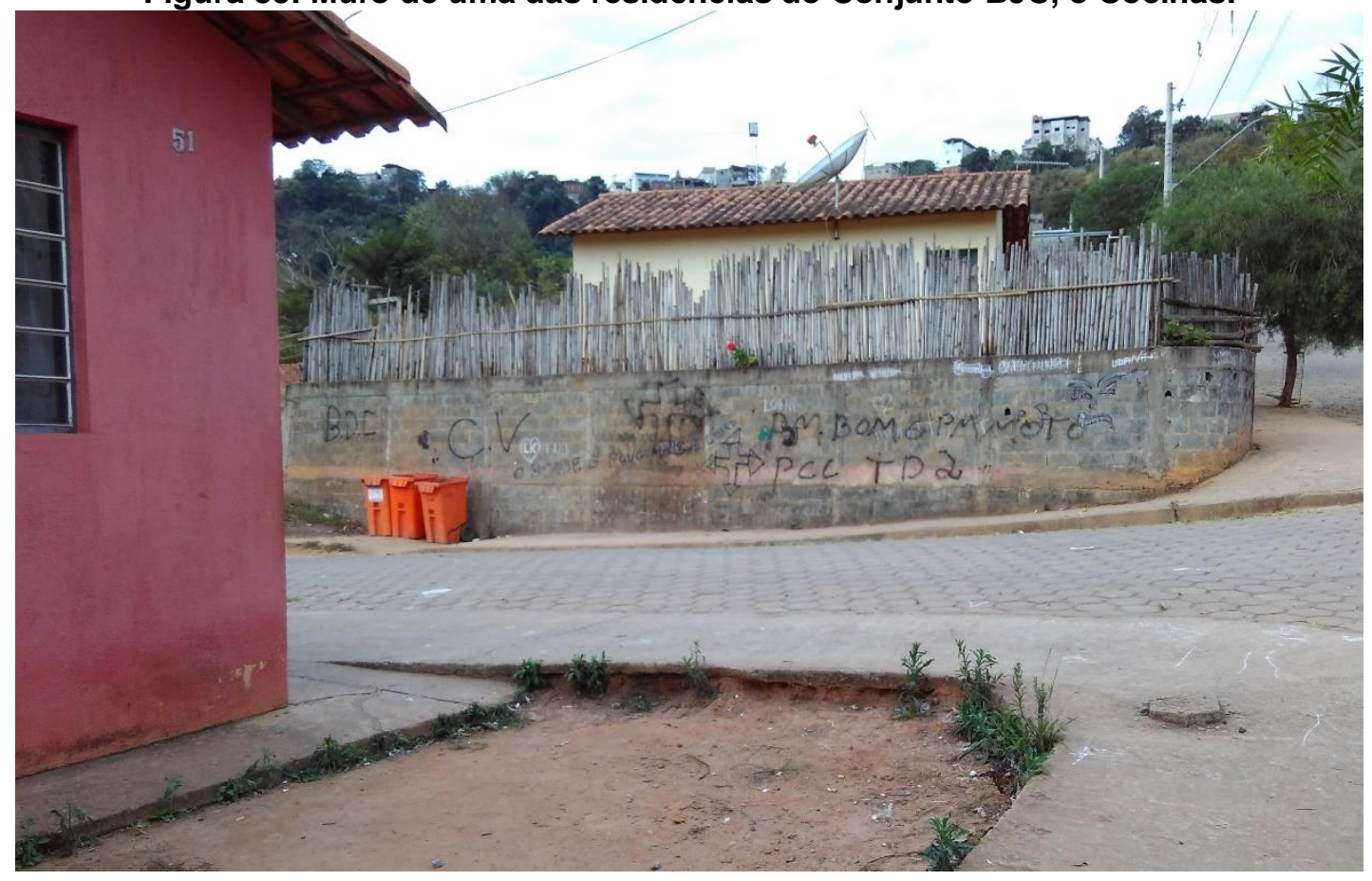

No muro dessa moradia estão pichadas algumas siglas e frases.

Fonte: Acervo do autor, 2015

As pessoas do tráfico de drogas em cidades de pequeno porte são, na verdade, como varejistas que compram as drogas dessas facções nas capitais mais próximas (Belo Horizonte e Rio de Janeiro) de acordo com preço e a facilidade. As drogas podem ser identificadas, ainda segundo o policial, a partir das características de embrulho ou pela cidade fornecedora, quando se tem essa informação. As inscrições de duas diferentes siglas de facções provavelmente se explicam, portanto, pela mudança de fornecedores.

Mesmo ao analisarmos essas informações, não podemos excluir o poder do tráfico de drogas de arregimentar pessoas e de provocar violência. Afinal, mesmo em cidades de pequeno e médio porte existem disputas territoriais e a cobrança de dívidas e serviços não prestados, resultando em crimes de grande 
impacto para a percepção de violência ${ }^{102}$. Assim, podemos inferir que a presença do tráfico, mesmo que não tenha pessoas "iniciadas" em grandes facções do crime organizado, gera certo temor aos moradores e certamente se configura como um fator que influencia a pouca incidência de movimentações coletivas, tendo em vista que essas necessariamente passam por contatos e conversas com vizinhos não muito conhecidos. Ademais, as movimentações poderiam chamar a atenção da mídia, de moradores próximos ou do Estado.

O policiamento no local é aparentemente regular nos períodos diurnos. Em algumas ocasiões de visita aos conjuntos, foram vistas viaturas fazendo ronda entre as casas. Contudo, os moradores afirmam que as rondas acontecem apenas nesse período e esporadicamente, mas que, quando acionada, a Polícia Militar não é prestativa, muitas vezes recusando-se a atender as chamadas, como relatado pelo entrevistado 12 (66 anos, BJC). Segundo esse morador e sua esposa, os policiais só aparecem se houver assassinato e, do contrário, não se interessam pelos problemas de eventuais brigas e furtos ocorridos na localidade: "Se roubar aqui de noite não vem, não! Aí ês pergunta pra gente assim: 'já matou alguém? Tem alguém morto aí?' É isso!". Quando a entrevistada 14 foi perguntada sobre o policiamento, sua resposta foi: "[risos] Vem nada! No começo que nós mudou pra cá, no começo parecia até que eles ia morar aqui. Achei até que eles ia fazer uma guarita, pra eles fica aqui Porque eles vinham quase direto. Quase todos os dias vinha uma viatura aí. Aí, na época não tinha muita coisa" (Entrevistada 14, 47 anos, BJC)

Dessa forma, podemos destacar, desde já, alguns fatores limitantes às apropriações dos espaços nos conjuntos. São eles: a má qualidade dos equipamentos urbanos destinados ao encontro e lazer; parte dos próprios moradores, que se apropriam de certas áreas, normatizando-as quanto a seus usos possíveis e afastando outros usos que não obedeçam à norma dos que exercem o domínio territorial e; a criminalidade ou o risco de associação à ela

\footnotetext{
102 Viçosa registrou 26 homicídios apenas no período de janeiro a agosto de 2017, quando uma onda de crimes fez a cidade registrar seu recorde histórico desse tipo de crime, que vinha sendo contabilizado desde 2012. Ver mais em: <https://g1.globo.com/mg/zona-da-mata/noticia/ondade-homicidios-faz-vicosa-atingir-numero-recorde-em-2017.ghtml> Acesso em: 13 jan. 2018
} 
que os pais e responsáveis veem na aproximação de crianças e adolescentes dos espaços utilizados por indivíduos supostamente ligados à atividades ilícitas, como pode ser observado na fala da entrevistada 11 (30 anos, moradora do Coelha), quando perguntada sobre quem danificou a pracinha: "Porque aqui tem muita droga, então é assim, complicado. O lugar é bem complicado, é um pouquinho difícil de lidar"

Com relação aos usos e às apropriações em locais externos aos conjuntos, os principais fatores limitantes são, como já poderíamos inferir em uma análise apriorística, a distância e a restrição de mobilidade. Observa-se para os conjuntos, portanto, certo grau de segregação com relação à cidade. $A$ localidade encontra-se em uma distância que é percorrida a pé por parte dos moradores, pois não representa grande distância, sobretudo se compararmos a implantação dos conjuntos em Viçosa com relação aos conjuntos de cidades de maior porte. Contudo, mesmo relativamente próximos de serviços e outros bairros, as dinâmicas socioespaciais reveladas, bem como as condições de mobilidade e ainda, apontam para a segregação socioespacial dos conjuntos. A segregação e a homogeneidade de situações socioeconômicas das famílias poderia gerar certa coesão para a coletividade. No entanto, como explicitado acima, existem outros fatores que influenciam no cotidiano local e nas relações de sociabilidades entre os moradores, bem como influenciam no sentido de limitarem a participação e a construção de uma coletividade.

\subsection{A casa própria como fator de permanência e a apropriação da moradia}

Todas as entrevistas com os moradores foram realizadas em suas residências. A primeira observação feita, portanto, foi sobre o local escolhido por cada entrevistado para a realização da entrevista. Excetuando-se uma família, todas escolheram a sala de estar. A exceção foi a moradora que está em situação de ocupação, que escolheu uma mesa em seu quintal para a atividade (Figura 36).

Em resposta sobre os espaços mais utilizados em sua residência, a entrevistada 13 (47 anos, BJC) responde rapidamente que é o quintal. Sua 
moradia apresenta-se com variados problemas internos e externos, devido ao tempo de abandono e à depredação relatados.

Figura 36: Mesa de refeição da família da entrevistada 13, Conjunto BJC.

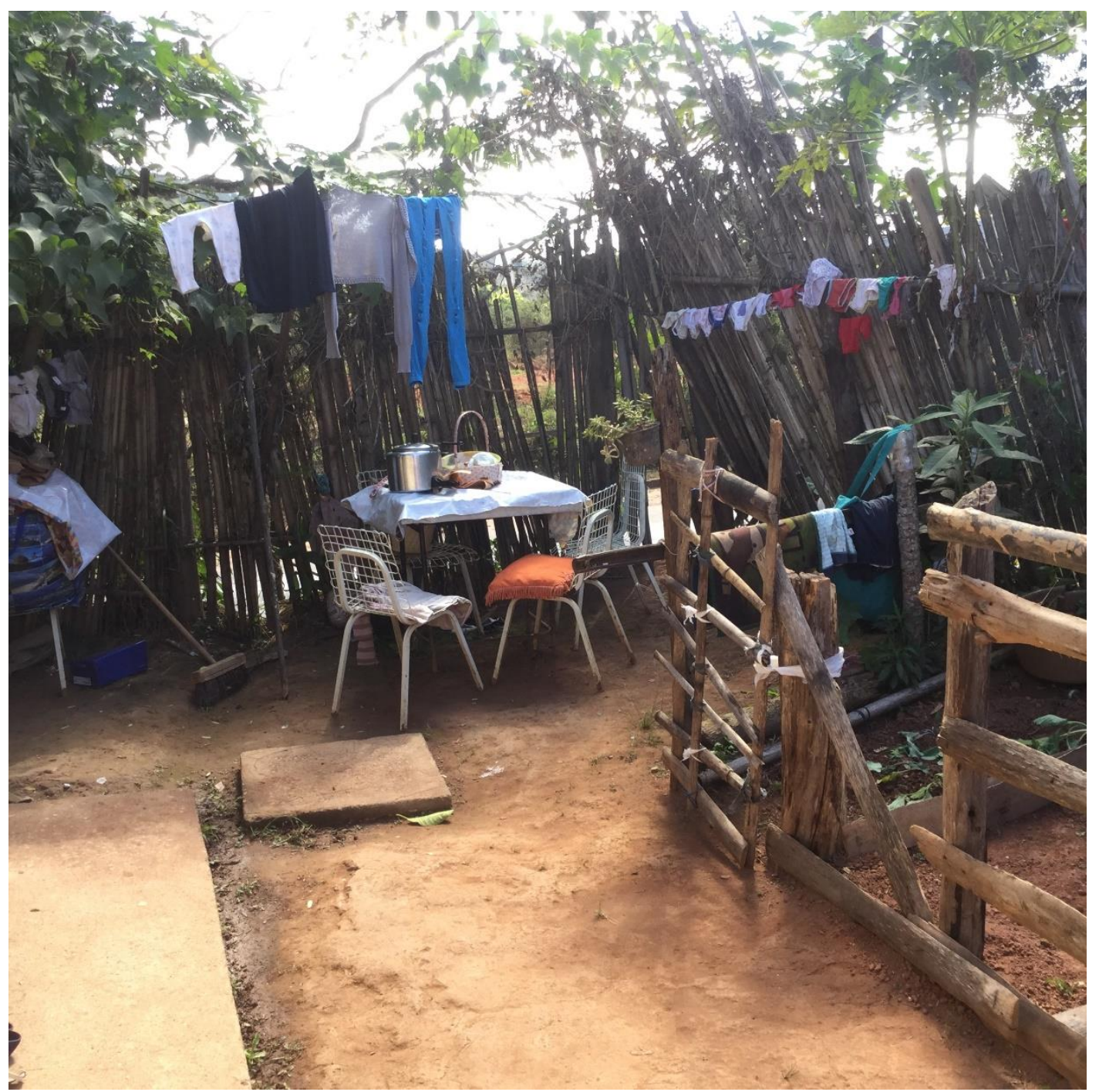

Mesa utilizada durante a entrevista com a moradora em situação de ocupação da moradia (Entrevistada 13, 47 anos, BJC)

Fonte: Acervo do autor, 2016

Os problemas de instalações elétricas e de equipamentos hidráulicos, somado ao tamanho diminuto dos cômodos da residência dificultam a realização das tarefas cotidianas familiares. Deve-se ressaltar também que a residência abriga 5 pessoas, três crianças (com 10, 11 e 12 anos), um jovem de 26 anos (filho mais velho) e ela, a entrevistada. Por esses motivos, a moradora é categórica em dizer que o quintal é o espaço de maior atividade da casa, principalmente as coletivas, como as refeições: "Ah, eu uso mais o quintal. A 
casa é muito pequena! Quintal... e a gente fica mais no quintal, né M. [filha mais nova]? Até coloquei essa mesinha aqui [onde foi realizada a entrevista], pra cá, né M. [filha mais nova]? [Risos] Refeições é aqui fora, né? Cozinha muito pequena! Pequena demais"

Com certo embaraço, a moradora pede que não sejam tiradas fotos internas da moradia quando ao final da entrevista foi requisitada sua autorização para tal. Os ambientes externos foram fotografados com liberdade e, ao final, a moradora pediu ainda que fosse tirada uma foto dela com suas filhas mais novas que estiveram presentes durante a entrevista. Registro que não deve ser comum para a família.

O parquinho, como já revelamos, não se configura mais como um espaço próprio para as brincadeiras das crianças. Mesmo a localização da praça ser em frente à residência, o que facilitaria os usos e apropriações pelas suas filhas, o espaço não é utilizado por suas filhas pois a moradora não permite às crianças que brinquem na rua desacompanhadas e, desse modo, resta a elas o quintal e a casa. Contudo, como afirmou a entrevistada, as brincadeiras às vezes atrapalham a privacidade dos outros ambientes: "Se tiver assistindo televisão, atrapalha, entendeu? Muito estreitinho [o espaço interno]" (Entrevistada 13, 47 anos, BJC). Portanto, o mesmo quintal de realização da entrevista serve também como o principal espaço para as brincadeiras das crianças, segundo a entrevistada (13, 47 anos, BJC).

Das residências visitadas, a família que está em situação de ocupação mostra-se como a que mais se apropria de seu quintal. Além dos fatos supracitados, a moradora construiu no quintal um cercado onde cultiva uma pequena horta. Ademais, trouxe para a fachada frontal da casa uma série de vasos, latas e baldes com plantas, ornamentando a entrada de sua moradia (Figura 37).

Observa-se também a partir da foto que a entrada da residência é feita pela cozinha, na parte de trás do imóvel, forçando a passagem por parte do quintal. Apesar dos sinais de depredação ainda existentes na casa, as plantas e o quintal se mantém bem cuidados. Segundo a moradora, os concertos 
necessários para a moradia não podem ser realizados por dois motivos: ela não tem dinheiro para isso e, mesmo se tivesse, trata-se de imóvel que não a pertence e, por isso, não valeria seu "investimento".

Figura 37: Área externa da casa da entrevistada 13.

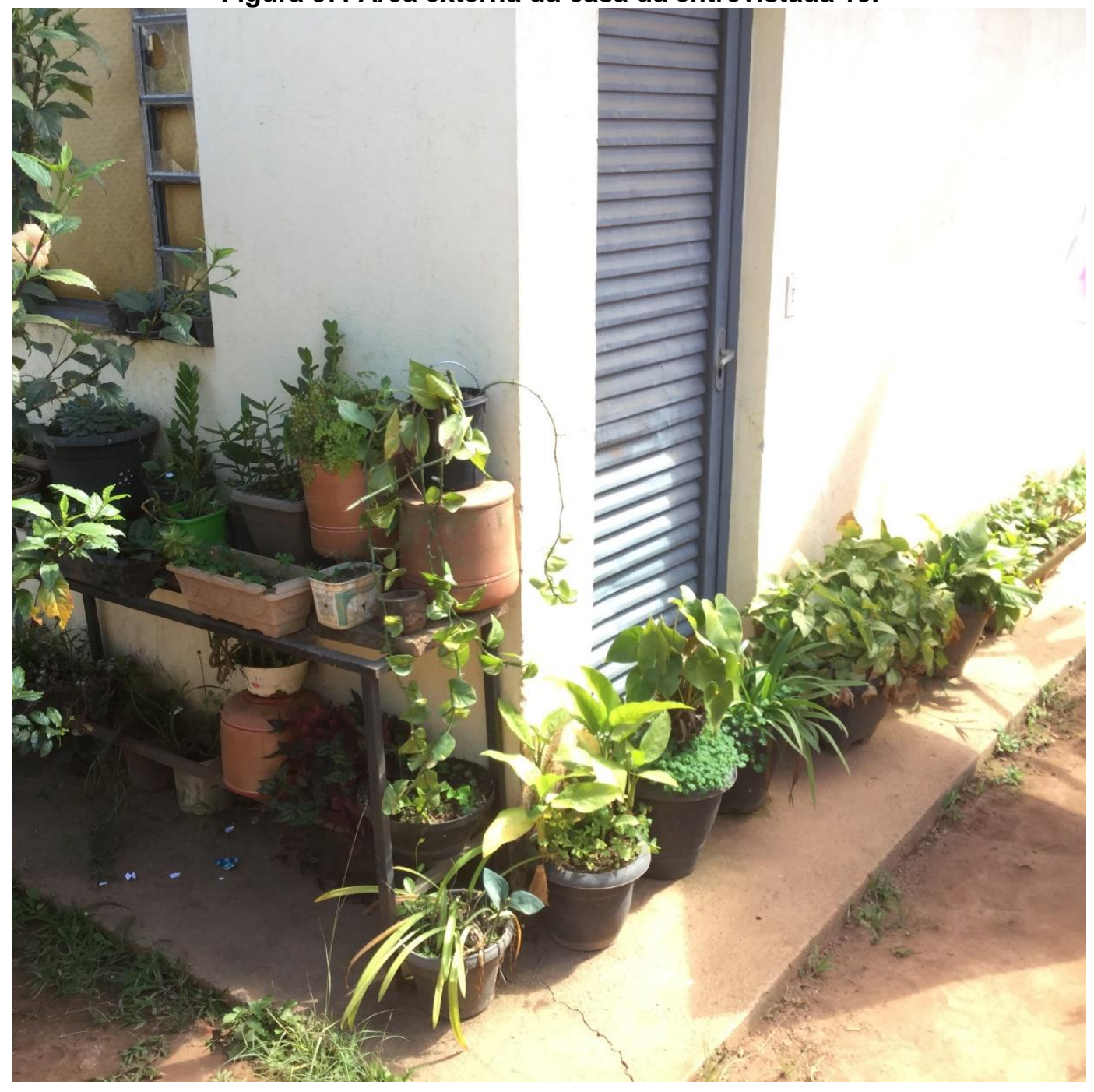

Conjunto de plantas usadas para ornar a fachada da residência cuja família está em situação de ocupação (Entrevistada 13, 47 anos, BJC).

Fonte: Acervo do autor, 2016

A presença de plantas nas entradas das residências é algo muito comum no conjunto. Grande parte das casas têm plantas na fachada frontal, algumas compondo cercas-vivas para o lote da moradia. São sinais de que há a presença de alguém, afinal, plantas necessitam de cuidados para permanecerem vivas, controladas e belas. Ou seja, passam a informação de que há vida ocupando e cuidando daquele espaço. Mesmo ocupando a área que poderia receber um 
automóvel, as hortas e plantas ornamentais encontradas no ambiente doméstico estavam, geralmente, dispostas no espaço reservado à garagem, além de ocuparem o espaço do afastamento frontal.

A entrevistada 13 se orgulha de sua horta. Durante a realização da entrevista, a moradora é interrompida por um vizinho que pede para pegar chuchu que brotava nos limites do terreno da entrevistada. Prontamente a moradora pede à filha que dê ao vizinho também uma abobrinha que nascia em sua horta. O registro fotográfico relatado acima tem como pano de fundo o cercado da horta.

Além de hortas e plantas ornamentais, parte dos moradores criam galinhas. Não é raro ver galinhas e galos soltos pelas ruas dos conjuntos. $O$ entrevistado 12 relata: "Hoje tem uns dois pezinhos de laranja. Tô criando as galinhas. Então, tô satisfeito com a casa. Eu tô satisfeito com a casa. Também não tô mal satisfeito com o lugar não, não é isso? Mas acho que deveria ser mais investido...". Para esse mesmo morador, a residência é boa, o problema são os moradores que deveriam ter sido selecionados antes de serem aprovados no programa.

Dentre os outros sinais de apropriação e/ou alteração das residências, podemos destacar o que é realizado primeiro pelos moradores: a construção de uma cerca ou muro. Mesmo os moradores que não dispõe de renda para cercar seus lotes improvisam com bambus e até mesmo a placa informativa da construção dos conjuntos (Figura 38). No quintal da entrevistada 22 pode-se observar as ferramentas utilizadas na construção da cerca, além das estacas de bambu que restaram. Segundo a moradora, ela mesma construiu o cercado nos fundos do lote.

A entrevistada 14 conta com orgulho do dia em que terminou a construção do muro de sua residência, relatando ser um sonho realizado pois sentia falta desse item para completar a segurança de sua moradia e família. Por outro lado, os moradores que dispõe de mais recursos logo construíram muros e portões, algo tido como de grande importância para eles. Além dos muros, ampliações nas garagens e na área dos cômodos também podem ser facilmente vistas pelos 
conjuntos. Há algumas poucas casas com dois pavimentos e muitas outras com sinais de ampliação de suas áreas.

Figura 38: Uma das residências cujo proprietário improvisou uma cerca.

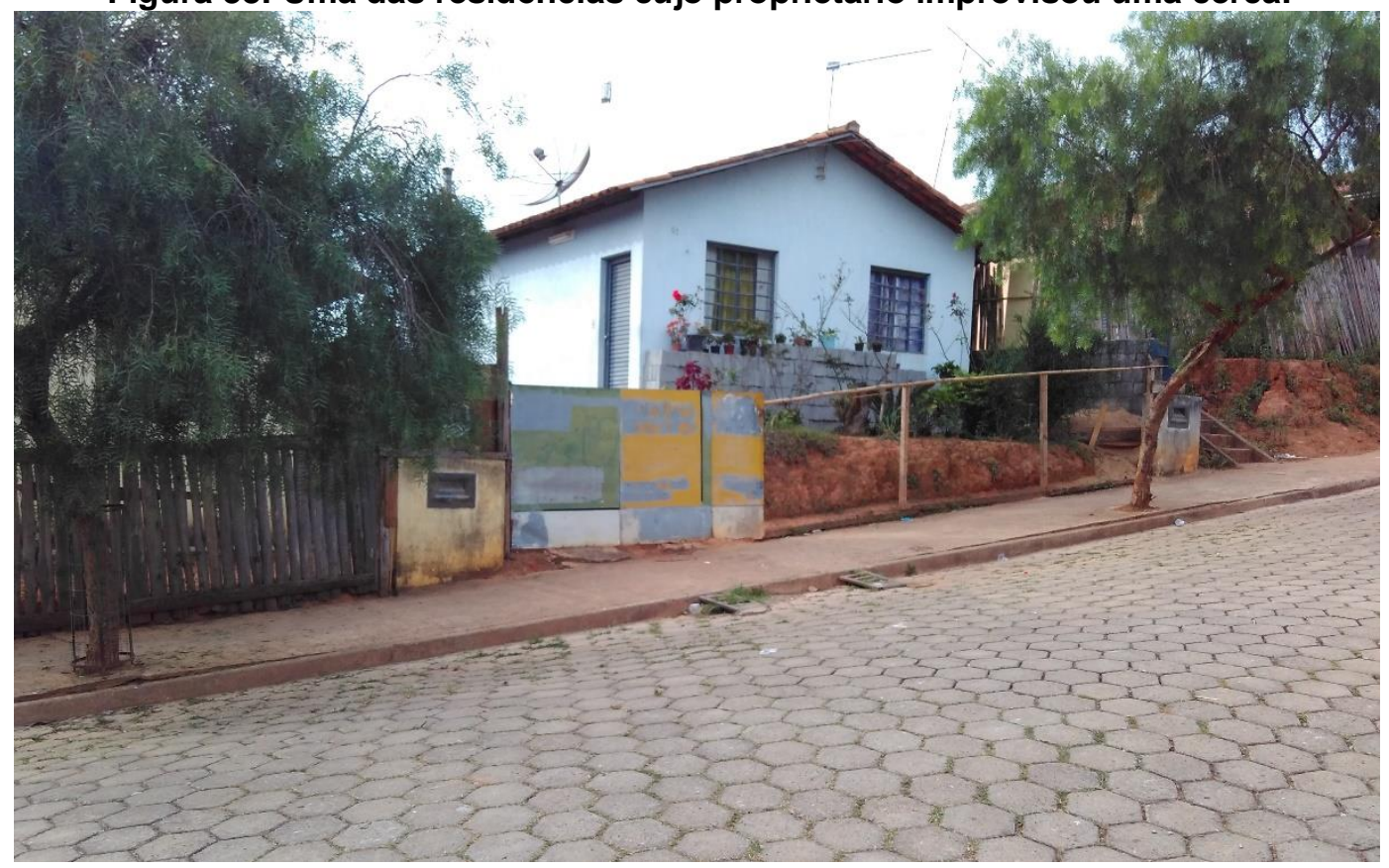

Residência cuja cerca foi feita a partir do reaproveitamento da placa indicativa da obra de construção do conjunto.

Fonte: Acervo do autor, 2016

Os usos dos espaços internos das edificações mostram-se variados de acordo com a família visitada. Em todas as salas de estar havia um aparelho televisor e, pelo menos, um sofá. Apesar das entrevistas serem realizadas neste espaço de cada casa, a sala não é sempre o destino das visitas. Amigos e parentes podem ficar também nos quintais ou até mesmo na cozinha, como relata a entrevistada 22: "[recebo] Na sala, ali mesmo. Aí tem vezes que eu tô lá fora lavando uma roupa ou qualquer coisa e elas vão pra lá também. Eu tô na cozinha e tem vezes que elas levam a cadeira pra cozinha e fica apertadinho, fica ali, junto comigo, conversando. É muito bom!"

A cozinha é o espaço interno que mais gera reclamações. Segundo os moradores entrevistados, essa porção da casa é muito pequena e não comporta bem as atividades que deveriam ser realizadas ali. É comum encontrar uma mesa na sala de estar sem que se tenha qualquer área para refeição na cozinha, como no caso da moradia da entrevistada 22 (25 anos, CSF) (Figura 39). Isso 
se dá pela centralidade deste móvel para uma família. As mesas são, dessa forma, utilizadas como superfície para as refeições, como lugar de conversas e de realização de tarefas cotidianas. No caso dos moradores em fase escolar, a mesa posta na sala de estar pode ser o único local adequado para estudos na casa. A sala é, dessa forma, o ambiente mais ocupado por móveis, aparelhos eletrônicos (de som e TV) e por itens familiares como porta-retratos e imagens sacras.

Figura 39: Mesa que exerce diferentes funções para os moradores

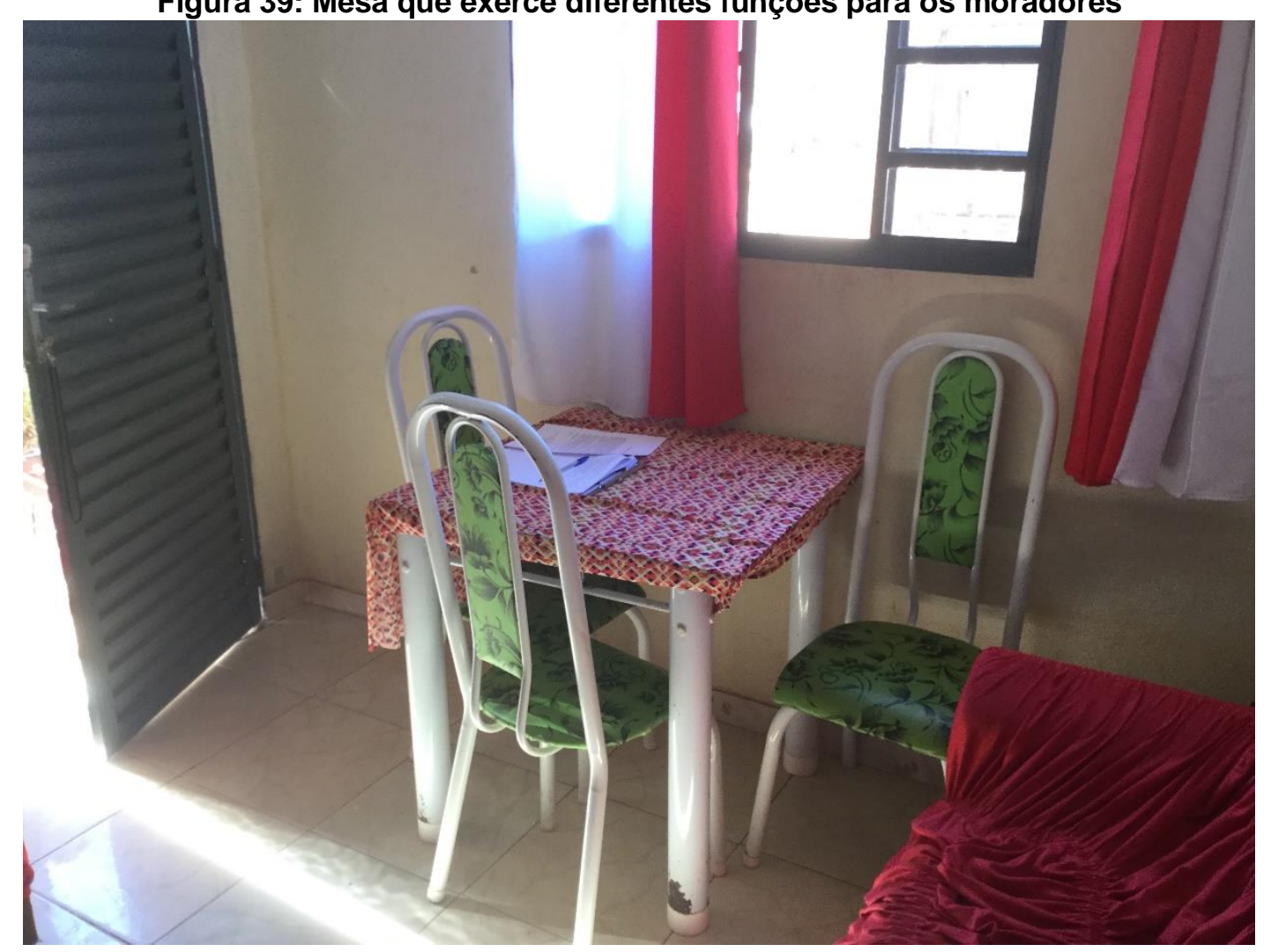

Fonte: Acervo do autor, 2016

Apesar do significado positivo do acesso à casa própria, como a realização de um "sonho", nas palavras do entrevistado 12 (66 anos, BJC), o imóvel também é visto como investimento pelos moradores. O mesmo entrevistado, quando perguntado sobre a permanência no imóvel, revela que pretende ampliá-lo visando a sua valorização para, talvez, vendê-lo. Semelhante compreensão de outras famílias dos conjuntos. Algumas famílias, segundo relatos, já se mudaram e alugam ou venderam o imóvel adquirido por meio do PMCMV. 
Esse mesmo entendimento, ligado às suas trajetórias de vida, os faz entender também a importância da moradia própria. Uma das respostas mais ouvidas diante da pergunta sobre as qualidades da moradia foi: "Porque é meu, né!" (Entrevistada 11, 30 anos, BJC). Ou, nas palavras da entrevistada 22: “(..) e aqui é meu, né! Meu e dos meus menino"

De modo geral, os entrevistados têm uma boa avaliação das casas, ressaltando que elas têm as qualidades mínimas para uma moradia. Mesmo assim, parte dos moradores expressam desejos de mudança dos conjuntos, revelando que só não saíram ainda por falta de oportunidades melhores de moradia, naturalmente. O principal fator de permanência nos conjuntos é a segurança econômica da família. As situações vividas por parte dos moradores os relembra da sensível condição de se viver com custos elevados de aluguel.

Outro fator que se mostrou importante foi quanto aos laços de amizade e as relações familiares presentes nos conjuntos. Segundo a entrevistada 22 (25 anos, CSF):

Eu pensei em sair daqui muitas vezes [risos]. Mas pelas amizades eu não saí. Da última vez que meu companheiro 'teve um probleminha', né. Aí, assim, ele ia alugar uma casa lá no Laranjal, longe, aí, assim, eu ia ir com ele pra lá, com as meninas. Só que assim, aí depois eu pensei bem e as meninas falando pra não ir, pra não ir... aí depois eu falei 'ah'... Aí eu falei com ele que se ele quisesse ir ele podia ir, que eu não ia ir não.

A fala da moradora revela ainda outro aspecto importante da propriedade do imóvel: as escrituras são feitas, preferencialmente, no nome da mulher. Dessa forma, há outro fator que materializa na residência uma certa liberdade de escolha, juntamente com o Programa Bolsa Família.

\subsection{Alienação espacial: considerações sobre a produção do espaço social}

Os moradores têm a percepção de que o espaço da residência é deles, mas que os conjuntos não. O MCMV construiu, então, espaços alienados, em um amplo sentido da palavra. Os espaços dos conjuntos e a arquitetura das moradias foram concebidas sem a participação dos moradores, assim como as 
relações de vizinhança que também não foram observadas durante o processo de implementação do Programa. Os espaços nasceram estéreis e alienados.

Ao se mudarem, aparecem os primeiros conflitos e desconfianças. Não há o que os conecte enquanto vizinhança. Ademais, o Estado não promove ações para as dimensões social e cultural, o que poderia contribuir para a construção de um corpo social mais coeso. As famílias se voltam para a esfera privada e 0 espaço público passa a ser, gradualmente, de domínio de organização criminosa, como a experiência histórica já nos apontava no BNH. Assim, os espaços dos conjuntos foram verticalmente impostos e posteriormente tomados.

Contudo, entre estes tempos, o da produção e o do domínio do tráfico, houve a possibilidade de construção coletiva dos conjuntos enquanto lugares, como nos apontou as diferentes situações de reivindicações políticas, de festas comunitárias e de sociabilidades, usos e apropriações nos espaços públicos dos conjuntos. Para além dos primeiros conflitos, houve a possibilidade também das primeiras construções de coletividade social e política. Essas organizações políticas e apropriações incipientes foram, no entanto, atravessadas pela organização criminosa que a esta altura certamente apresentava maior coesão e força do que a população local. Assim, as horizontalidades que estavam em fase de formação não tiveram tempo de amadurecimento antes de serem colocadas de lado por forças externas.

A realidade de poucas apropriações espaciais fora do domicílio próprio indica essa alienação. Os moradores não se apropriam dos espaços de fato dos conjuntos. As ruas e calçadas são apropriadas pontualmente em determinados horários e dias, e por determinada população; a infantil, sobretudo. Voltam-se para dentro das moradias, onde encontram a "tranquilidade" afirmada em quase todas as entrevistas e que lhes é cara, tendo em vista as trajetórias de vida da maioria dessas famílias. Cabe lembrar que a realização do sonho de uma das entrevistadas foi finalizar a construção dos muros que cercam sua casa: "Pra falar a verdade, eu pulei de alegria!" (Entrevistada 14, 47 anos, BJC)

As possibilidades de ascensão cidadã, conectando o alcance do direito fundamental da moradia à liberdade e possibilidade de ação coletiva, portanto, 
nos moldes estatais vigentes, deveriam passar pela esfera estatal. A cidadania, então, extrapola seus limites individuais, pois é coletiva, e perpassa as diferentes dimensões sociais ligadas ao cotidiano e, dentre elas, os espaços urbanos e as instituições públicas.

Assim, a ausência de relações de vizinhança e sociabilidades, além do Estado complacente quanto à violência presente no cotidiano dos moradores, tem-se o cenário para a entrada e domínio nos conjuntos da criminalidade e do tráfico de drogas. Segundo os relatos dos moradores, a depredação teve como agentes os próprios moradores e pessoas de fora que frequentam os conjuntos por suas relações com o tráfico de drogas. Como os espaços são novos, sem relações históricas de civilidade e sociabilidade, a resistência oferecida é pequena aos ataques à coletividade.

Tanto nos relatos sobre a situação da coleta de lixo e das lixeiras quanto sobre os parquinhos e seus mobiliários, percebe-se o distanciamento dos moradores de uma relação comunitária. As sociabilidades são pontuais e as questões relativas aos espaços e problemas conjuntos são abordadas também pontualmente. As incipientes tentativas de organização coletiva em prol de bens públicos foram ignoradas pelo Estado e não efetivadas no cotidiano dos moradores.

O passado de certa precariedade influencia na permanência nos conjuntos. Algumas das moradoras entrevistas relatam a vontade de mudar de bairro e utilizam a narrativa da segurança econômica familiar como fator de permanência, como visto. As trajetórias de vidas dos entrevistados com mais idade revelam a fragilidade na questão habitacional, constantes mudanças, coabitação e habitação em área de ocupação, como exposto neste trabalho. Para muitos dos moradores, o PMCMV é a materialização permanente da mudança de abordagem do Estado com relação às famílias economicamente mais pobres e vulneráveis. As trajetórias de vida dos moradores sinalizam para essa mudança: do Estado quase ausente ao Estado que organiza e gere a vida dessas famílias. 


\subsection{A política habitacional do PMCMV e a cidadania pelo consumo: primeiras conclusões}

Os conjuntos localizam-se em uma porção segregada da malha urbana da cidade, o que faz deles locais pouco movimentados, ou "tranquilo", nas palavras de alguns dos entrevistados. Soma-se o fator de degradação dos equipamentos públicos dos dois conjuntos, que também influencia muito nas sociabilidades e apropriações dos espaços, com o um baixo movimento de automóveis, pois poucas famílias os possuem e, como resultado, observamos as ruas como principais locais de apropriação. As ruas são as localidades mais utilizadas para brincadeiras, jogos, encontros marcados e espontâneos entre os moradores.

Devemos observar e analisar a relação entre o desenho proposto para 0 espaço e as apropriações nele realizadas. Vê-se que, no caso das praças, o desenho de implantação não favorece os usos cotidianos do espaço, tornandoos espaços residuais. Não são propícias ao constante movimento e vigilância coletiva, questões centrais na observação feita por Jacobs (2011) para seu livro Morte e vida de grandes cidades.

Outro fator é o tamanho desses espaços, que não consegue atender a públicos diferentes ao mesmo tempo, sobressaindo o domínio territorial do grupo de maior poder, os adultos, sobretudo os ligados ao tráfico de drogas. A normatização do espaço causa uma dependência da preservação do espaço por apenas um público, que desempenha ali as poucas atividades específicas deste grupo; no caso, o futebol. Os espaços que deveriam ser renovados e conservados por meio de sua utilização constante e variada, passam a ser de domínio e exclusão.

Assim, o público infantil e adolescente, que é o mais ativo nos espaços, vêse forçado a utilizar outros espaços ou são confinados dentro de suas casas pelos responsáveis, preocupados com o comportamento e a criminalidade de parte dos jovens e adultos que utilizam os espaços públicos. Das várias visitas que realizei aos conjuntos, do ano passado até o período atual, nunca presenciei crianças ou adolescentes brincando nas praças, e só eventualmente algum jovem sentado na calçada de acesso à praça ou empinando pipa, geralmente 
sozinho ou em pares. Ao que parece, segundo minhas observações, tais jovens cumprem o papel de vigias dos conjuntos. Em mais de uma visita, um adolescente acompanhava minha movimentação a partir de sua bicicleta, à distância, dando voltas nos quarteirões e parando nas esquinas de melhor amplitude do campo de visão.

A criminalidade é um fator limitador das apropriações dos espaços. Como vimos, o público infantil e adolescente têm o uso do espaço restringido. Resta a eles apropriarem-se das ruas e terrenos baldios próximos aos conjuntos. 0 conjunto perde, de certa maneira, o sentido do urbano coletivamente construído com a falta de espaços propícios para abrigarem uma multiplicidade de usos livres, capazes de consolidar espaços como parte da identidade dos moradores. Como afirma Lefebvre:

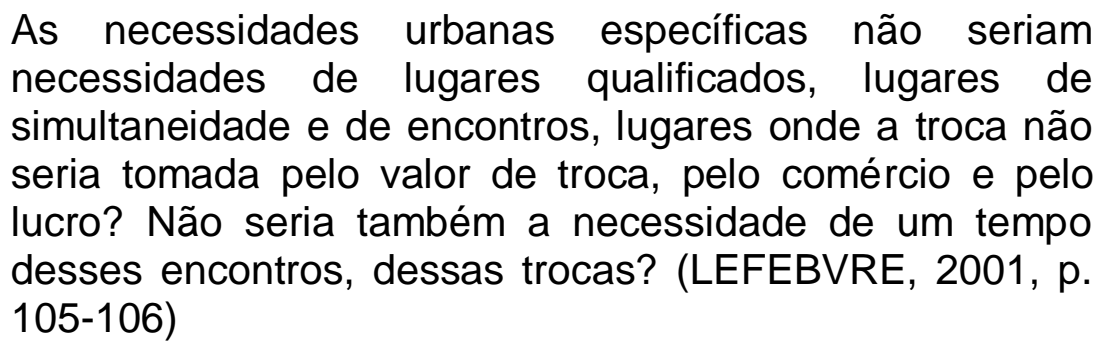

Dessa forma, vê-se que a falta de locais "apropriáveis" aumenta a sensação de esterilidade dos conjuntos, com suas ruas e casas quase idênticas e espaços públicos esvaziados, consolidando a ideia de que esses conjuntos do programa MCMV produziram, nos termos de Lefebvre, habitat sem habitar. O MCMV, não só em Viçosa, como discutido por Harvey (2014, p 12), pode ser visto como uma tentativa estéril de reprodução de uma tipologia que apela para um certo bucolismo como que pedindo desculpas por ser uma não-cidade, uma representação - esvaziada - de uma habitação rural, de interior.

Como observa Lefebvre (1964) sobre a falta de adolescentes em uma cidade construída para atender a uma região fabril da França, Lacq-Mourenx: "À cidade jovem falta juventude (...). Falta um elemento: aquele que mais intensamente introduz a turbulência, o imprevisto e o jogo numa coletividade. " (LEFEBVRE, 1964, p. 13). E esse parece ser um fator decisivo também nos conjuntos do PMCMV em Viçosa. 
Outro fator também observado é sobre a falta de mobilidade. Esse talvez seja o fator mais destacado nas entrevistas quando desqualificam a vida nos conjuntos. Isso se dá pela mobilidade afetar diferentes aspectos do cotidiano que estão direta ou indiretamente relacionados com as possibilidades de deslocamento. Em primeiro lugar, fica claro que a falta de transporte público e o seu alto preço afetam sobremaneira o cotidiano e as possibilidades de apropriações de espaços. Como já mencionado, existem apenas seis horários de ônibus saindo dos conjuntos.

Essas linhas, como é padrão, estão ligadas aos horários e itinerários dos bairros com maior disponibilidade de emprego e serviços. Dessa forma, a liberdade de locomoção fica limitada pelos horários. As linhas de volta aos conjuntos também vêm somar ao problema, pois não permitem atividades noturnas por parte dos moradores em outras localidades. Tendo em vista que as características de formação, profissão e escolaridade dos moradores e que a maior parte dos empregos da cidade estão ligadas ao setor de serviço, e ainda que alguns desses serviços têm funcionamento noturno (portaria de edifícios, serviços gerais em restaurantes e bares, táxis, segurança e vigilância etc.), observa-se que a limitação de horários de transporte público é uma limitação também nas oportunidades de emprego e renda.

A partir do PMCMV e de outras ações e políticas públicas, podemos apontar que em detrimento de uma consciência de classe ou, ao menos, da instrumentalização das camadas mais pobres tornando acessíveis e democráticas a cidade e a educação formal de qualidade, promoveu-se a cidadania pelo consumo que é, como já afirmamos, um deslocamento e esvaziamento dos significados políticos de cidadania, tornando-a outra coisa que não a participação social e política efetiva e democrática das pessoas no espaço social.

A cidadania pelo consumo parte do entendimento geral sobre a importância que a propriedade privada tem para a sociedade capitalista. Dessa forma, com o MCMV possibilitando a liberdade com relação ao ônus excessivo 
com o aluguel, além do cartão do Programa Minha Casa Melhor ${ }^{103}$ para compra de móveis e eletrodomésticos, houve o aumento do poder de consumo das famílias, que conseguiram alcançar um padrão de consumo suficiente para qualificar o espaço de moradia, pois uma moradia não se configura apenas pelo seu espaço físico, mas também por possibilitar que a vida cotidiana se realize por inteira: local de descanso, de alimentação, de lazer, de convivência familiar, de segurança e de identidade. Criou-se um ambiente no qual o consumo se sobrepôs aos problemas estruturais da pobreza e desigualdade do país.

103 Programa de subsídio de crédito para as famílias moradoras dos empreendimentos do PMCMV. O cartão permite a compra de materiais de construção, de móveis e de eletrodomésticos e inclui essa população no mercado do consumo de bens duráveis. 


\title{
$\boldsymbol{6}_{\text {conclusoes }}$
}

\begin{abstract}
"A vida cotidiana esmagadora, reduzida a sua essência, às suas funções banais e, ao mesmo tempo, quase dissolvido na fragmentação de gestos e na repetição de atos. Aqui está diante de você, completamente ou quase alienada e reificada, e talvez concordando, mas talvez também tente recuperar" (LEFEBVRE, 1962, tradução minha)
\end{abstract}

A partir das apropriações - e da falta delas - se desperta na pesquisa o elemento das redes sociais como "estratégia de sobrevivência" em um ambiente de escassez (materiais e de oportunidades, como de trabalho, por exemplo). Assim, onde e quando as oportunidades são escassas, as redes aparecem com maior relevância para a melhoria das condições de vida, por meio de ajudas mútuas que resultam em trabalhos (temporários ou não; informais ou não); ou melhoria com relação ao tempo para realizarem as atividades cotidianas, tal qual ocorre quando as crianças de uma família são deixadas aos cuidados de outra família para que os adultos possam trabalhar, fazer compras e etc. As redes de solidariedade são maiores em espaços de pobreza pois constituem-se em estratégias de sobrevivência e de melhoria da qualidade de vida.

A soma do fator das redes sociais com os fatores dos programas de distribuição de renda (como o Bolsa Família) e ainda a titularidade feminina da moradia resultam em oportunidades de emancipação feminina inédita no cenário dos espaços de pobreza brasileiros. A possibilidade de a mulher conseguir tempo para trabalhar por conta das solidariedades das vizinhas (mulheres, sobretudo) pode ajudar a quebrar o ciclo de pobreza no qual o(a) filho(a) mais velho(a) se vê obrigado a cuidar dos irmãos mais novos na ausência dos pais (da mãe, sobretudo), perdendo o tempo com o qual deveria dedicar-se às tarefas escolares e ao desenvolvimento das atividades próprias da infância e adolescência: o brincar, o aprender e o construir laços afetivos.

Dessa forma, mesmo que os instrumentos governamentais de assistência e de distribuição de renda não representem mudanças "significativas" no âmbito da melhoria da qualidade de vida da geração beneficiária, tais instrumentos, 
quando combinados de forma constelar, podem representar mudanças reais no ciclo da reprodução da pobreza, permitindo, mesmo que ainda não em sua maioria, a melhoria das oportunidades para a geração seguinte, ao proporcionar acesso à educação e habitação em segurança (econômica, familiar, alimentar, etc).

No entanto, de acordo com os elementos históricos, urbanísticos e sociais do contexto aqui apresentado, a segregação imposta às famílias moradoras dos conjuntos é clara, confirmando impressões tiradas a priori e a tendência nacional de aplicação do programa nas cidades. Têm-se na segregação desses conjuntos um fator de manutenção das hierarquias socioespaciais históricas da cidade, de gerenciamento da pobreza no âmbito político-econômico tanto local quanto nacional.

Aproximando-se do escopo dessa pesquisa, que tem como foco a população local, podemos elencar três principais esferas da vida social dessa população, com conexões e interseções entre as três, nas quais temos na segregação desses conjuntos (mas que podemos extrapolar para outros conjuntos estatais de HIS) como fator determinante: a) na - falta de participação e visibilidade na vida pública da cidade; b) na restrição das redes possíveis de sociabilidade e na consequente restrição de oportunidades; c) na gestão política-econômica da pobreza.

Não se pode, contudo, restringir a pobreza de característica estrutural às ligações sociais das pessoas, pois incorreríamos no reducionismo da questão mais importante nos estudos de populações economicamente pobres no Brasil: seu cotidiano. Relevar o caráter secundário do 'capital social de relações pessoais' nas sociedades modernas, sejam centrais ou periféricas, tornando completamente invisíveis os 'capitais econômico e cultural' (sendo o 'capital cultural' precisamente uma mistura da herança dos valores familiares e do capital escolar), os quais esses, sim, são os 'elementos estruturais' e são as chaves para a compreensão da 'hierarquia social' da sociedade moderna, é tornar 'invisível' causas efetivas e reais da desigualdade, marginalidade, sub-cidadania e naturalização da diferença que nos caracteriza primordialmente como sociedade (SOUZA apud MAGALHÃES, 2015, p. 89). Cabe ressaltar que os 
termos "capital cultural" e "capital social" aqui apontados seguem a compreensão de Pierre Bourdie (PORTES, 2010), na qual analisa-se a rede de relações sociais dos indivíduos visando entender as possibilidades de acessos e de apropriações de recursos disponíveis em suas redes. ${ }^{104}$

Contudo, voltamos ao estudo de Marques (2005) para assinalarmos que, apesar de "secundário", o critério da rede de relações pessoais acaba sendo um diferencial para populações empobrecidas pela estrutura social do país. Ou seja, tal critério poderia incrementar as possibilidades de arranjo econômico dessas famílias já marginalizadas, caracterizando-se como uma possibilidade a mais de obtenção de trabalhos formais e de maiores rendimentos, tendo em vista a sensível situação da desigualdade histórica da qual fazem parte e do pouco acúmulo de recursos e acessos culturais e econômicos.

Dessa forma, as restrições das possibilidades das redes sociais tornam a segregação imposta pela implantação dos condomínios do MCMV acabem por diminuir as chances de estabilidade econômica, algo "maquiado" pela sensação de estabilidade advinda da aquisição da casa própria através do programa. A curto prazo, portanto, têm-se uma estabilidade ligada a uma situação habitacional que por algumas famílias não havia sido experimentada em suas trajetórias (a certeza da permanência e de que as parcelas da moradia serão quitadas sem maiores esforços).

A longo prazo, porém, com a localização segregada dos conjuntos e com o fator estrutural da pobreza familiar, as chances de ascensão social continuam muito limitadas. Conclui-se que o Programa, dessa forma, acaba por ser um instrumento estatal de gestão da pobreza e de perpetuação da segregação socioespacial, sobretudo se somarmos ao contexto o tipo de presença do Estado que se faz no cotidiano dos moradores, confirmando a atuação histórica restrita do Estado brasileiro de controle, policiamento e manutenção das classes sociais,

104 Importante frisarmos aqui que os termos "capital social" e "capital cultural" são utilizados em obediência também aos autores e autoras citados no decorrer do trabalho (como MARQUES e TORRES, 2005). Ademais, "capital cultura" tem sido utilizado como terminologia para frentes diversas de compreensões do espaço, da economia e da cultura, inclusive compreensões institucionalizadas para favorecimento de grupos rentistas, como no caso de ações do Banco Mundial. Caso este do qual este estudo diverge e, por isso, cabem as devidas ressalvas. 
“(..) uma condição colonial persistente que gera resultados em relação às limitações do processo democrático" (MAGALHÃES, 2015, p. 96).

Segundo a compreensão geográfica de lugar, fica claro que este não pode ser produzido enquanto produto tanto quanto a localização é produzida segundo Villaça $^{105}$ (Ver capítulo 2). O Programa Minha Casa Minha Vida se propôs a construir habitações e atacar o déficit populacional, segundo a narrativa dos responsáveis à época. A primeira parte do objetivo foi alcançada com sucesso quantitativo, ainda que em muitos casos a faixa de maior concentração do déficit foi secundarizada em relação a outras de melhor poder aquisitivo. O MCMV foi a política habitacional de maior número de unidades construídas em menor tempo na história do país. A segunda parte, relativa ao déficit, fracassou por uma falha estrutural do programa que não atacou a questão fundiária, como já havia sido denunciado desde o lançamento do programa por pesquisadores da área de habitação.

O objetivo nunca foi o de "construir lugar", evidentemente. Contudo, de acordo com as pesquisas mais recentes realizadas sobre o MCMV do ponto de vista do urbanismo, da urbanidade e da sociologia urbana (sobretudo as pesquisas etnográficas ${ }^{106}$ ), podemos concluir que uma consequência foi a de não promover espaços que pudessem se constituir como lugares, e que esse fato é conteúdo de uma forma de se fazer política social característica do "período lulista" de aquisição de direitos sociais pelo consumo. Historicamente sempre houve o lugar (enquanto espaço) do pobre nas cidades. O MCMV reafirma a condição de espaço segregado, destituído de possibilidades de apropriações e de vivacidade, criando espaços urbanos sem urbanidade, bairros sem relações de vizinhança e etc. Resumindo, o MCMV criou uma dupla negação da cidade (a exemplo dos condomínios fechados), pois é um espaço construído sem as características de cidade (localidades ativas; centralidades; espaços de comércio, serviços e lazer) e porque é a materialização de uma sociedade estruturalmente excludente, que historicamente nega a cidade aos despossuídos.

$\begin{array}{ll}105 & 2015 \\ 106 & \text { Como a da Thaís Rosa, } 2014 .\end{array}$


O Estado nega aos empreendimentos que façam parte da cidade (implantação em locais ermos muitas vezes distantes da malha urbana consolidada) enquanto nega as possibilidades de cidade que aquele espaço poderia ter, ou possibilitar (resumem-se, muitas vezes, a bairros-dormitórios, desconsiderando a inserção urbana, os laços de vizinhança pré-estabelecidos e a possibilidade de se construir uma centralidade). Uma negação dupla, portanto: intra e intercidade.

Para completar o quadro de alienação do espaço pelos moradores (tanto os locais quanto os do restante da cidade, que não conhecem nem compreendem o modo de produção daquele espaço e nem mesmo o próprio espaço construído) a questão da insegurança, somada ao trabalho extenuante e aos deslocamento demorados e dificultados fazem com que os moradores permaneçam todo o tempo livre dentro do empreendimento e voltados para a vida privada, limitando assim seus respectivos campos de ações e, consequentemente, as possibilidades de usos e apropriações.

Conclui-se que as apropriações dos espaços pelos moradores entrevistados seguem, então, as limitações de possibilidades de espaços apropriáveis em um conjunto implantado de maneira totalmente alheia às reais necessidades dessa população. Os poucos usos e sinais de apropriações coletivas de espaços públicos corroboram com a revisão bibliográfica dos arranjos institucionais do Programa, pois diferentes estudos apontam para um esvaziamento do conteúdo político do MCMV; reverberando em espaços de frágeis conteúdos simbólicos ou coletivos positivos e nos quais sua população volta-se para o espaço familiar, fechando-se em pequenas redes de sociabilidade e com fortes tendências ao individualismo. Uma das afirmações mais ouvidas no campo empírico foi sobre como o lugar é "tranquilo" pois "cada um fica na sua", o que sintetiza parte dos achados do estudo.

Espera-se que o presente trabalho tenha auxiliado na compreensão das relações de formatação e desenho institucional com sua aplicação e com os diversos problemas de dimensões econômicas e socioespaciais que emergem dos espaços dos conjuntos do Minha Casa Minha Vida em Viçosa, confirmando as leituras de outras pesquisas em temáticas correlatas e que têm como objeto 
o Programa e/ou a sua população atendida. Conclui-se ainda que o MCMV em Viçosa obedeceu a outra questão comum a outras cidades que receberam o Programa, qual seja, a estratégia de valorização fundiária local que é, assim como o desenho institucional, alheio às necessidades específicas da população.

Dada a importância vista na pesquisa com relação às redes de sociabilidades para as famílias, podemos apontar também para a necessidade de estudos que abordem essa questão no âmbito ainda do MCMV pois, devido ao volume do Programa e da quantidade e qualidade dos estudos já realizados em temas correlatos, poderíamos caminhar para o aprofundamento da questão.

\subsection{Considerações para trabalhos futuros: apontamentos para uma abordagem da segregação em cidades médias}

Em áreas metropolitanas, a segregação vista nos termos das distâncias é um fator de ampliação da espoliação urbana. Isso pois a população pobre segregada passa grande parte do seu dia em deslocamento da casa para o trabalho, dentro de transportes públicos muitas vezes precários e lotados. Esse tempo perdido não é contabilizado no ganho salarial, mas descontado do tempo de reposição da força de trabalho, ou seja, do lazer e descanso necessários. Há, assim, um ciclo de precarização da vida: baixa escolaridade - trabalho precário - baixa renda - moradia em local distante - espoliação urbana - perda de tempo em transporte e falta de mobilidade - falta de tempo para descanso e lazer - baixa qualidade de vida.

A segregação, contudo, não pode ser vista apenas do ponto de vista das distâncias. As distâncias para os locais de trabalho, lazer e serviços públicos compõe apenas uma dimensão da restrição de possibilidades, das limitações de apropriação e da consequente imobilidade social. Assim, a sociedade organizada na cidade - local de encontro e trocas e que produz e se reproduz a partir de seus espaços - cria possibilidades ou restrições de acessos tanto aos seus produtos (objetos, tecnologias e espaços) quanto à comunicabilidade e sociabilidade que caracteriza a sociedade moderna. 
A segregação, então, deve ser vista como a concentração de grupos sociais em determinados espaços de forma que a totalidade do espaço urbano seja produzida e consumida a partir dos interesses de alguns grupos em detrimento dos outros. A segregação determina as apropriações diferenciadas (com maior ou menor liberdade e possibilidades de apropriação) dos produtos coletivamente produzidos, dentre os quais o próprio espaço urbano e suas localizações.

As segregações determinam, portanto, quem controla os espaços e, consequentemente, ordena a distribuição dos corpos nos espaços. A segregação se dá, portanto, como consequência de qualquer sociedade cujo objetivo é a apropriação individual do trabalho coletivo e a produção e manutenção de monopólios; reiterando que um dos resultados do trabalho coletivo é, justamente, o espaço urbano e os monopólios são, nesse contexto, as melhores localizações.

A segregação determina também a qual leque ou sistema de oportunidades as pessoas têm acesso, como nos mostrou Marques (2005), Torres (2005), D'Andrea e Almeida (2005) e etc. Populações segregadas em territórios de pobreza ou precariedades acabam por ter menores chances de conclusão do ciclo escolar básico, maiores chances de sofrer com a violência, menores oportunidades de emprego e renda, acesso a equipamentos e serviços públicos de menor qualidade e etc. A segregação, portanto, é essencial na manutenção das diferenciações sociais, ou seja, na perpetuação da pobreza e da "cidadania mutilada" (SANTOS, 2014).

Nesse processo, o Estado tem participação decisiva tanto produzindo espaços segregados voltados à população mais pobre, quanto direcionando melhorias espaciais aos territórios já bem estruturados e abastecidos; quanto, também, legislando ou se omitindo em favor das elites urbanas e contra as camadas mais pobres. Dos agentes produtores do espaço urbano, dessa forma, - Estado carrega grande responsabilidade na produção e reprodução da segregação, como já mencionamos citando Marcuse (2004) dentre outros no capítulo 2. Nos últimos anos, como observado por Rizek (2017), o Estado vem realizando uma série de ações e políticas públicas que mercadificam direitos e 
contribuem no controle das populações pobres; promovendo a narrativa de individualização das responsabilidades e a perda do conteúdo político da cidadania, o que torna cada vez mais distante a desalienação e a cidadania plena.

As apropriações "populares", seguindo nesse sentido, são reversões da lógica imposta da distribuição dos corpos em espaços de bonança ou carência. Ou seja, apropriar é transformar um local de carência em um lugar de coexistência (mesmo que a carência não seja imediatamente dirimida); é produzir lugares. Ou seja, apropriar-se é tomar as rédeas da produção espacial e social para si e não mais depender de imposições verticais e externas que ditam qual lugar e como ocupá-lo e usufruí-lo. O lugar apropriado passa a ser de uma coletividade e a ela cabe decidir os rumos daquele espaço de acordo com as demandas dessa coletividade. Apropriar-se é uma forma de negar a "distribuição dos corpos" e a produção do espaço impostas.

Assim como cada cidade tem seu próprio histórico de produção de espaços segregados, de segregação forçada e autosegregação, mesmo no Brasil as cidades passaram por diferentes processos e apresentam diferentes características sociais e espaciais. Neste sentido, observamos que a construção do conhecimento sobre esse tema tem sido manejada a partir de estudos em cidades grandes e regiões metropolitanas. Isso se dá, principalmente, por dois motivos: i) a observação de processos perversos e rápidos componentes da segregação (como os descritos no capítulo 2); ii) a maior presença de pesquisadores e centros de pesquisa nessas cidades, facilitando a produção e acesso às informações.

Este cenário, inferimos, contribuiu para que a questão das segregações em cidades médias ou de pequeno porte não contassem com grande atenção por parte das pesquisas. Isso não significa, contudo, que as cidades médias não apresentem espaços segregados, sobretudo após a construção massiva de conjuntos do Programa Minha Casa, Minha Vida nessas cidades. É evidente, desde um primeiro olhar, a segregação imposta às populações desses novos 
conjuntos. Cabe adiantar que as cidades médias apresentam os menores déficits habitacionais e, no entanto, foram as principais atendidas pelo Programa.

Cabe lembrar que a segregação em cidades médias é um processo muito mais lento e menos perverso do que em grandes cidades, de modo geral. Há uma homogeneidade maior do espaço urbano em sua totalidade, como podemos observar nas divisões mais orgânicas entre bairros e na maior fluidez arquitetônica e urbanística entre os diferentes espaços. As diferenças de renda, localização, acessos a equipamentos e serviços, locais de trabalho não fogem tanto à escala humana.

Por exemplo, Viçosa apresenta uma renda per capita de 384 reais no bairro mais pobre da cidade, enquanto o bairro mais rico tem renda per capita de 1755 reais (CENSUS, 2014). Ambos estão semelhantemente distantes do centro e dos equipamentos públicos. Contudo, existem duas diferenças que podem determinar a situação de segregação desses espaços: a) enquanto o primeiro teve sua ocupação não por escolha das famílias, mas por necessidade, o segundo é um condomínio autosegregado construído por professores universitários que buscavam as amenidades existentes fora da malha urbana, e sem abrirem mão, contudo, de acessos viários facilitados para os ambientes de trabalho e; b) as qualidades arquitetônicas e urbanísticas dos locais que evidenciam as diferenças sociais.

Apesar de evidente, a segregação nessa categoria de cidades, quando posta a partir do conhecimento no tema (de origem metropolitana), pode se mostrar inadequada de ser caracterizada como segregação de fato. Dessa forma, um dos objetivos desse trabalho foi colocar em debate a questão da segregação com relação à sua aplicação a cidades que não sejam grandes ou pertencentes a alguma região metropolitana.

Procuramos destacar no presente trabalho as questões territoriais para além das espaciais. Ou seja, houve uma reflexão sobre os fatores que compõe a segregação, de modo a trazer para o debate (ou dar mais ênfase) o cotidiano urbano e suas possibilidades (ou à negação desse cotidiano e dessas possibilidades). Pretende-se com este trabalho acender o debate sem, contudo, 
findá-lo ou encaminhá-lo, tendo em vista que para isso se faz necessário maior volume de referencial bibliográfico e de pesquisas empíricas que possam apontar em uma direção comum. Reitera-se, portanto, o caráter exploratório dessas considerações finais, fazendo apontamentos e realizando um exercício reflexivo sobre a questão habitacional e da segregação em cidades de pequeno e médio portes. 


\section{REFERÊNCIAS BIBLIOGRÁFICAS}

ABÍLIO, Ludmila C. A gestão do social e o mercado da cidadania. In: CABANES; GEORGES; RIZEK; TELLES. Saídas de emergência. São Paulo: Boitempo Editorial, 2011, p. 297-316.

ABRAHÃO, Sérgio Luís. Espaço público: do urbano ao político. Annablume Editora, 2008.

AGAMBEM, Giorgio. O que é um dipositivo?. Florianópolis: Outra Travessia, 2005.

ALMEIDA, R.; D'ANDREA, T. Estrutura de oportunidades em uma favela de São Paulo. In: E. Marques e H. Torres (orgs.), São Paulo: segregação, pobreza e desigualdade sociais. São Paulo: Senac, 2005.

ALVES, Zélia M. M. B.; SILVA, Maria H. G. F. D. da. Análise qualitativa de dados de entrevista: uma proposta. Paidéia, Ribeirão Preto-SP, n. 2, p. 61-69, jul. de 1992.

ALVES, Giovanni. Neodesenvolvimentismo e Estado neoliberal no Brasil. 2013. Disponível em:

<https://blogdaboitempo.com.br/2013/12/02/neodesenvolvimentismo-e-estadoneoliberal-no-brasil/> Acessado em: 15 dez. 2015.

AMORE, Caio S.; SHIMBO, Lúcia Z.; RUFINO, Maria B. C. Minha casa... e a cidade? avaliação do programa minha casa minha vida em seis estados brasileiros. Rio de Janeiro: Letra Capital, 2015.

ANDRÉ, Maria E. D. A. Texto, contexto e significado: algumas questões na análise de dados qualitativos. Cadernos de Pesquisa, São Paulo: 66-71. maio de 1983. 
ARANTES, Otília Beatriz Fiori. Gentrificação Estratégica. In: Berlim e Barcelona: duas imagens estratégicas. São Paulo: Annablume, 2012. p. 1326.

ARENDT, Hannah. Os domínios público e privado. In: A Condição Humana. Rio de Janeiro: Forense Universitária, 2010. p. 26-96.

AZEVEDO, Sérgio de. Vinte e dois anos de política de habitação popular (1964-1986): criação, trajetória e extinção do BNH. In: Revista de Administração Pública, Rio de Janeiro, v. 22, p. 107-119, out./dez. 1988.

BALL, Michael. The development of capitalism in housing provision. International Journal of Urban and Regional Research, v. 5, n. 2, p. 145-177, 1981.

BARONE, Ana C. C. Team 10: arquitetura como crítica. São Paulo, Dissertação (Mestrado em Arquitetura e Urbanismo) Faculdade de Arquitetura e Urbanismo, Universidade de São Paulo, abr. 2000.

BARUCO, Grasiela C. da Cunha; CARCANHOLO, Marcelo Dias. Crise dos anos 1970 e as contradições da resposta. Anais do XI Encontro Nacional de Economia Política, Sociedade Brasileira de Economia Política (SEP), 2006.

BENEVOLO, Leonardo. História da cidade. São Paulo: Perspectiva, 2011.

BOAL, Augusto. A Estética do Oprimido. Rio de Janeiro: Garamond, 2009.

BOLAFFI, Gabriel. Planejamento urbano: reflexão sobre a experiência recente. In: Novos estudos Cebrap, São Paulo, v. 1, n4. p. 50-53, nov. 1982.

A questão urbana: produção de habitação, construção civil e mercado de trabalho. In: Novos Estudos Cebrap, São Paulo, v. 2, n¹, p. 6168, abr. 1983. 
Habitação e urbanismo: o problema e o falso problema. In: MARICATO, Ermínia (org). A produção capitalista da casa (e da cidade) no Brasil industrial. São Paulo: Alfa-omega, 1987.

BONDUKI, Nabil. Os pioneiros da habitação social no Brasil: cem anos de construção de política pública no Brasil. Volume I (Série: Os pioneiros da habitação social no Brasil). São Paulo: Editora UNESP: Edições SESC, 2014.

BOTEGA, Leonardo da R. De Vargas a Collor: urbanização e política habitacional no Brasil. In: Espaço Plural, ano VIII, n¹7, p. 66-72, $2^{\circ}$ semestre de 2007.

A Política Habitacional No Brasil (1930-1990). In: Revela, Praia Grande/SP, ano 1, n², mar. 2008.

BORGES, Raphael M. Análise de desempenho térmico de unidades habitacionais construídas no Conjunto Habitacional Benjamin José Cardoso em Viçosa-MG. Dissertação (Mestrado em Engenharia Civil), Programa de Pós-Graduação em Engenharia Civil - UFV, Viçosa, 2013.

BRASIL. Decreto $n^{\circ}$ 64.825, de 15 de julho de 1969. Institui, sob a forma de fundação, a Universidade Federal de Viçosa e dispõe sôbre sua constituição.

BRASIL. Lei no 11.977, de 7 de julho de 2009. Dispõe sobre o Programa Minha Casa, Minha Vida - PMCMV e a regularização fundiária de assentamentos localizados em áreas urbanas.

BRASIL DE FATO. David Harvey: "Urbanização incompleta é estratégia do capital". Disponível em: <http://www.brasildefato.com.br/node/26691> Acesso em 25/11/2013. 
BRIGHENTI, Andrea M. The publicness os Public Space. Trento: Dipartamento di sociologia e ricerca sociale, Março de 2010.

CALDEIRA, Teresa P. Cidade de muros: crime, segregação e cidadania em São Paulo. São Paulo: Editora 34, 2000.

CAMPOS, Pedro H. P. Anos de chumbo e concreto. In: Revista de História. Disponível em: <http://www.revistadehistoria.com.br/secao/artigos-revista/anosde-chumbo-e-concreto> Acesso em: 16 nov 2015.

A formação do grande capital brasileiro no setor da indústria de construção: resultados preliminares de um estudo sobre causas e origens. In: Revista de História, ano 7, n9, 2009.

CANO, Wilson. Reflexões sobre o papel do capital mercantil na questão regional e urbana no Brasil. In: . Ensaios sobre a crise urbana do brasil. Campinas: UNICAMP, 2011, p. 181-207.

CARNEIRO, Patrício Aureliano Silva. Conquista e povoamento de uma fronteira: a formação regional da Zona da Mata no leste da Capitania de Minas Gerais (1694-1835). Dissertação de Mestrado. Belo Horizonte: UFMG, 2008.

CARVALHO, Aline W. B.; STEPHAN, İtalo I. C. Eficácia social do Programa Minha Casa Minha Vida: discussão conceitual e reflexões a partir de um caso empírico. Caderno Metrópoles., São Paulo, v. 18, n. 35, p. 283-307, abr. 2016.

CARVALHO, Aline W. B.; STEPHAN, Ítalo I. C; GUEDES, Marina G. M. SUSTENTABILIDADE E EFICÁCIA SOCIAL DO PROGRAMA MINHA CASA, MINHA VIDA: UM ESTUDO DE CASO. In: Simpósio Brasileiro de Qualidade do Projeto no Ambiente Construído. Viçosa: UFV, 2015 
CARVALHO, André S. O papel da cidade de Viçosa-MG na rede urbana: a especialização funcional de uma cidade média mineira. Dissertação (Mestrado em Geografia), Departamento de Geografia - UFES, Vitória, 2014.

CHAUÍ, Marilena. Democracia e sociedade autoritária. Goiânia: Café de Ideias, 2013. (Comunicação oral)

CLAPSON, Mark. Suburban neurosis and new town blues. In: Invincible Green Suburbs, Brave New Towns: Social Change and Urban Dispersal. Manchester University Press, 1998, p. 121-155.

CHERKEZIAN, Henry; BOLAFFI, Gabriel. Os caminhos do mal-estar social: habitação e urbanismo no Brasil. In: Novos estudos Cebrap, São Paulo, n50. p. 125-147, mar. 1998.

COELHO, Dayana D; CHRYSOSTOMO, Maria Isabel de J. Estratégias imobiliárias e a construção do "mito" do pai dos pobres na produção dos bairros periféricos de Amoras e Nova Viçosa (1970-1990). RA'E GA, Curitiba. Abril de 2015. p. 277-306.

CORRÊA, Roberto Lobato. O espaço urbano. São Paulo: Editora Ática, 1989.

CULLEN, Gordon. Paisagem Urbana. Lisboa: Edições 70, 1983.

CUNHA, Gabriel Rodrigues da. O Programa Minha Casa Minha Vida em São José do Rio Preto/SP: Estado, Mercado, Planejamento Urbano e Habitação. Tese (Doutorado em Arquitetura e Urbanismo) - Instituto de Arquitetura e Urbanismo, Universidade de São Paulo. São Carlos, 2014.

CRUZ, Tancredo A (coordenador). Retrato social de Viçosa V. Viçosa, MG: CENSUS, 2014. 
CYMBALISTA, Renato; MOREIRA, Tomás. Política Habitacional no Brasil: a história e os atores de uma narrativa incompleta. In: Participação Popular nas Políticas Públicas. São Paulo: Instituto Pólis, 2006.

DARDOT, Pierre; LAVAL, Christian. A nova razão do mundo. São Paulo: Boitempo Editorial, 2016.

Arqueología de lo común. In: Común: ensayo sobre la revolución em el siglo XXI. Barcelona: GEDISA, 2015. s/ página. Trecho disponível online para apreciação.

DEUTSCHE, Rosalyn. Uneven Development: Public Art In New York City. In: Evictions: Art and spatial politics. Massachusetts: MIT Press, 1998. p. 49-108.

DIAS, Adelaide L. N; CARVALHO, Aline W. B. de. FARIA; Teresa C. de A.; SANTOS, Janaina M. Análise comparativa dos processos de produção da irregularidade urbana nas áreas centrais e periféricas: o caso de Viçosa, MG. Oikos: Revista Brasileira de Economia Doméstica, Viçosa, v. 25, n.1, p. 114136, 2014.

DUARTE, Evaristo E. C.; POLA, Karina D. Trabalho em Marx e serviço social. Serviço Social em Revista, v. 12, n. 1, p. 179-201, 2009.

ENGELS, Friedrich. Sobre a questão da moradia. São Paulo: Boitempo Editorial, 2015.

FARIA, Vilmar E. Cinquenta anos de urbanização no Brasil: tendências e perspectivas. Novos Estudos Cebrap. São Paulo, n²9, mar. 1991, pp. 98119.

FERRO, Sérgio. O canteiro e o desenho.(1976). Arquitetura e trabalho livre. São Paulo: Cosac Naify, 2006. 
FREITAS, Petrus A. Trabalho assalariado, capitalismo e alienação: proposições acerca do complexo categorial do trabalho e a alienação. In: Revista Espacio Crítico, $\mathrm{n}^{\circ} 22$, semestre 1 de 2015, p. 52-58.

FUNDAÇÃO JOÃO PINHEIRO. Déficit habitacional no Brasil 2013-2014. Belo Horizonte: Centro de Estatística e Informações, 2016.

GRAUMANN, Carl F. The concept of appropriation (aneignung) and modes of appropriation of space. Heidelberg: Psychologisches Institut, 1976, p. 113125.

GUIMARÃES, Eliane Aparecida. O processo de implementação do Programa Minha Casa Minha Vida para a população de baixa renda: o caso de ViçosaMG. Dissertação (Mestrado em Economia Doméstica) - Departamento de Economia Doméstica, Universidade Federal de Viçosa. Viçosa, 2013.

GUTIÉRREZ, Emilio Martínez. Introducción: Ciudad, espacio y cotidianidad en el pensamiento de Henri Lefebvre. p. 29-50. In: LEFEBVRE, Henri. La producción del espacio. Espanha: Capitan Swing, 2013.

HAESBAERT, Rogério. Da desterritorialização à multiterritorialidade. Anais do X Encontro de Geógrafos da América Latina, São Paulo. Março de 2005. Disponível em: $<$ http://www.planificacion.geoamerica.org/textos/haesbaert_multi.pdf> Acesso em: 15/07/2015.

HALL, Peter G. Chapter 4: The City in the Garden. In: Cities of tomorrow: an intellectual history of urban planning and design in the twentieth century. Oxford: Blackwell Publishers, 1996, p. 86-135.

HARVEY, David. A produção capitalista do espaço. São Paulo: Annablume, 2006. 
O enigma do capital e as crises do capitalismo. São Paulo: Boitempo Editorial, 2011.

. Cidades rebeldes: do direito à cidade à revolução urbana. São Paulo: Martins Fontes, 2014.

HEIMSTRA, Norman W; McFARLING Leslie H. Psicologia ambiental. São Paulo: EPU, 1978, p.1-7.

HONÓRIO, Letícia de Melo. A PRODUÇÃO DO ESPAÇO EM UMA CIDADE UNIVERSITÁRIA: o caso de Viçosa, MG. Dissertação (Mestrado em Geografia), Departamento de Geografia - UFMG, Belo Horizonte, 2012.

IBGE. Censo Demográfico 2010. Disponível em: <http://www.ibge.gov.br/>. Acesso em: 20 set. 2015.

JACOBS, Jane. Morte e vida de grandes cidades. São Paulo: WMF Martins Fontes, 2011.

KENNETH, Frampton. História crítica da arquitetura moderna. São Paulo: Martins Fontes, 1997.

LAMAS, Jose M.R.G. Morfologia urbana e desenho da cidade. 3.ed, Porto: Fundação Gulbenkian, 2004.

LAVALLE, Adrian G. Por uma utopia ao alcance da mão: contracrítica antineoliberal do espaço público. In: MALAGUTI, Manoel Luiz (Org). A quem pertence o amanhã?: ensaios sobre o neoliberalismo. Edicoes Loyola, 1997.

LAVOS, Ana Paula Alves de. Sociabilidades em conjuntos habitacionais produzidos pelo Estado: o caso da COHAB Cidade Tiradentes. Dissertação (Mestrado em Arquitetura e Urbanismo) - Instituto de Arquitetura e Urbanismo, Universidade de São Paulo. São Carlos, 2009. 
LEFEBVRE, Henri. Septième Prélude: Notes sur la ville nouvelle. In: Introduction à la modernité. Paris: Ed. Minuit, 1962. Disponível em: <http://laboratoireurbanismeinsurrectionnel.blogspot.com.br/2013/10/lefebvremourenx-ville-nouvelle.html> Acesso em: 16/10/2017.

. Novos conjuntos urbanos - um caso concreto: Lacq-Mourenx e os problemas urbanos da nova classe operária. (In mimeo). São Paulo, FAUUSP, 1964.

. De lo rural a lo urbano. GAVIRIA, Mario (Org). Barcelona: Península, 1971.

. Urbanose 15: Entretien avec Henri Lefebvre. RÉGNIER, Michel (Org.). L'Office National du Film du Canada, 1972. Disponível em: <https://cidadesincomum.com/2016/09/01/entrevista-com-henri-lefebvre-1972legenda-em-portugues/> Acesso em: 13 dez. 2017.

A revolução urbana. Belo Horizonte: Ed. UFMG, 1999.

Direito à cidade. São Paulo: Centauro Editora, 2001.

. La producción del espacio. LOREA, Ion M. (Org.). Madrid: Capitán Swing, 2013.

LIMA, Rodrigo N. Surrealismo e a Internacional Situacionista: deambulações e derivas. In: PEIXOTO; DERNTL; PALAZZO; TREVISAN (Orgs.) Tempos e escalas da cidade e do urbanismo: Anais do XIII Seminário de História da Cidade e do Urbanismo. Brasília, DF: Universidade Brasília - Faculdade de Arquitetura e Urbanismo, 2014.

LYNCH, Kevin. A imagem da cidade. São Paulo: WMF Martins Fontes, 2011. 
MAGALHAES, Felipe N C. O neoliberalismo e a produção do espaço na metrópole: subjetividades, insurgências e redes na economia política da urbanização contemporânea. Tese (Doutorado em Geografia) - Instituto de Geociências da Universidade Federal de Minas Gerais, Belo Horizonte, 2015

MANTEGA, Guido. O nacional desenvolvimentismo. In: A economia política brasileira. Rio de Janeiro: Polis/Vozes, 1986, p. 23-76.

MARCUSE, Peter. Enclaves, sim; guetos, não: a segregação e o estado. In: Espaço \& debates n. 45, São Paulo: 2004.

MARIA, Ana C. de S; FARIA, Teresa C de A; STEPHAN, Ítalo I. C. Um retrato da evolução urbana de Viçosa-MG: impactos da federalização da UFV sobre a cidade (1969-2014). R. Bras. Planej. Desenv., Curitiba, v. 3, n. 1, p. 37-54, jan./jul. 2014.

MARICATO, Ermínia. Política habitacional no regime militar: do milagre econômico à crise econômica. Petrópolis: Vozes, 1987, 96 p.

Metrópole na periferia do capitalismo: ilegalidade, desigualdade e violência. 1. ed. São Paulo: Hucitec, 1996. Disponível em: $<$ http://www.usp.br/fau/depprojeto/labhab/biblioteca/textos/maricato_metrperif.p df> Acesso em: $01 \mathrm{dez} 2015$.

Habitação e cidade. São Paulo: Atual, 1997.

. A bomba relógio das cidades brasileiras. Revista Democracia Viva, v. 11, p. $3-7,2001$.

O impasse da política urbana no Brasil. Petrópoles: Editora Vozes, 2011a. 
. Metrópoles desgovernadas. Revista Estudos Avançados 25 (71), p. 7-22, 2011b.

MARQUES, Eduardo; TORRES, Haroldo. São Paulo: segregação, pobreza urbana e desigualdade social. São Paulo: Ed. Senac, 2005.

MARX, Karl. O caráter fetichista da mercadoria e seu segredo. In: O Capital livro I. São Paulo: Boitempo Editorial, 2017, p. 146-158.

. O processo de trabalho e o processo de valorização. In: O Capital livro I. São Paulo: Boitempo Editorial, 2017, p. 255-276.

Ministério das Cidades/Secretaria de Assuntos Estratégicos da Presidência da República. Pesquisa de satisfação dos beneficiários do Programa Minha Casa Minha Vida. Editado por Fernando Garcia de Freitas e Érica Negreiros de Camargo - Brasília, DF: MCIDADES; SNH; SAE-PR; IPEA, 2014.

MEDEIROS, Sara R. F. Q de. BNH: outras perspectivas. In: Anais da I Conferência Nacional de Políticas Públicas contra a Pobreza e a Desigualdade, UFRN, Natal-RN, Nov 2010.

MONTE, Luiz A. D. S. do. Deriva e psicogeografia na cidade contemporânea: experimento situacionista no centro do Recife. Dissertação de Mestrado (Departamento de Design da Universidade Federal de Pernambuco). Recife, 2015.

MORAIS, L. P. Comida, identidade e patrimônio: articulações possíveis. In: História: Questões \& Debates, n. 54, p. 227-254. Curitiba: Editora UFPR, jan./jun. 2011.

MORANTA, Tomeu Vidal; POL, Enric U. La apropiación del espacio: una propuesta teórica para comprender la vinculación entre las personas y los 
lugares. Anuário de psicologia da Universitat de Barcelona, Barcelona. 2005. p 281-297.

MOREIRA, Vinicius de S; SILVEIRA, Suely de F. R.; REIS, Francimar N. S. C. PROGRAMA MINHA CASA, MINHA VIDA: a percepção dos beneficiários como instrumento para avaliação. In: Revista Políticas Públicas \& Cidades., v.2, v.1, Jan./Abr. 2015, p. 67-90.

NASCIMENTO, Denise M.; BRAGA, Raquel C. de Queiroz. Déficit habitacional: um problema a ser resolvido ou uma lição a ser aprendida? RISCO: Revista de Pesquisa em Arquitetura e Urbanismo (online), [S.I.], n. 9, p. 98-109, jan. 2009. ISSN 1984-4506. Disponível em: <http://www.revistas.usp.br/risco/article/view/44765> Acesso em: 06 Mai. 2015.

NEGRI, Silvio Moisés. Segregação sócio-espacial: alguns conceitos e análises. In: Coletâneas do nosso tempo, v. 8, n. 08, 2010.

NETTO, José Paulo. Cotidiano: conhecimento e crítica. São Paulo: Cortez, 2012.

NETTO, Vinicius M. O espaço da prática social. In: Revista Contraste $\mathbf{n}^{\circ} \mathbf{2}$. São Paulo: FAUUSP, semestre II/2013.

- Classes sociais, mobilidades e a apropriação do espaço urbano. In:

Cidade \& Sociedade: as tramas da prática e seus espaços. Porto Alegre: Sulina, 2014, p. 67-86.

OLIVEIRA, Francisco de. Crítica à razão dualista: o ornitorrinco. São Paulo: Boitempo, 2011.

OLIVEIRA, M. Um Conceito de Cidadania para se Trabalhar a Cidade. In: Geografia, América do Norte, 1, set. 2009. Disponível em: 
<http://www.uff.br/geographia/ojs/index.php/geographia/article/view/10/8> Acesso em: 15 set. 2015.

OUDENAMPSEN, Merijn. A cidade como playground. In: PISEAGRAMA, Belo Horizonte, número 03, 2011, p. 52-55.

PANIAGO, Maria do Carmo Tafuri. Viçosa - mudanças socioculturais: evolução histórica e tendências. Viçosa: UFV, Impr. Univ., 1990.

PAULA, Karine de A. A PRODUÇÃO DO ESPAÇO URBANO VERTICAL NA ZONA CENTRAL DE VIÇOSA-MG, NO PERÍODO 1980-2012. Dissertação (Mestrado em Arquitetura e Urbanismo), Departamento de Arquitetura e Urbanismo - UFV, Viçosa-MG, 2013.

PASSOS, Flora D. R. Entre cantos, batuques e grafias: vivências culturais nos espaços públicos da zona portuária do Rio de Janeiro. In: XV ENANPUR, 15, maio de 2013. Recife: Anais dos encontros nacionais da ANPUR, 2013.

PEQUENO, L. R. B.; ROSA, Sara V. Inserção urbana e segregação espacial: análise do programa Minha casa Minha Vida em Fortaleza. In: Anais do XVI ENANPUR, Belo Horizonte, 2015.

PINHEIRO, Sérgio C. Lotes vagos em Viçosa-MG: repercussões legais, ambientais e econômicas no quotidiano da população e nas ações do poder público. Monografia (Especialização em Planejamento Municipal) Universidade Federal de Viçosa, Viçosa-MG, 2004.

PINTO, Marina B. Questão habitacional como expressão da questão social na sociedade brasileira. In: Revista Libertas, Juiz de Fora, v. 4 e 5, n. especial, p. 92-117, jan-dez 2004, jan-dez 2005.

PLANHAB - PLANO NACIONAL DE HABITAÇÃO. Contextualização do Plano Nacional de Habitação: análise e sistematização do contexto habitacional 
atual, constrangimentos, potencialidades e cenários possíveis. 2010. Disponível em: <www.cidades.gov.br>. Acesso em: 19 mai. 2017.

POL, Enric U. PSICOLOGÍA AMBIENTAL 007 | ENRIC POL - APROPIACIÓN DEL LUGAR. Proyecto vida urbana y biodiversidad. Madri: Universidad Autónoma De Madrid, 2011. Duração: $5 \mathrm{~min}$ e 20seg. Disponível em: < https://www.youtube.com/watch?v=e5L52ssO6VE\&list=PLA0CF557548DD261F \&index=7>. Acesso em: fev. de 2016.

PORTES, Alejandro. Capital social: origens e aplicações na sociologia contemporânea. Sociologia, Problemas e Práticas, Oeiras , n. 33, p. 133158 , set. 2000.

PORTUGAL, Josélia G. A relação entre os distintos grupos sociais na configuração de uma cidade: um estudo sobre a segregação sócio-espacial em Viçosa-MG. XIV Encontro Nacional da ANPUR, Rio de Janeiro, Maio de 2011.

QADEER, Mohammad A. Segregação étnica em uma cidade multicultural, Toronto, Canadá. In: Espaço \& Debates, v. 24, n. 45, p. 34-47, 2004.

REGO, Walquiria D L; PINZANI, Alessandro. LIBERDADE, DINHEIRO E AUTONOMIA: O caso da Bolsa Família. In: Revista de Ciências Sociais, 38, Abr. 2013, p. 21-42

PREFEITURA MUNICIPAL DE VIÇOSA. Relatório de diagnóstico da demanda por equipamentos e serviços urbanos: Conjunto Habitacional Fazenda Colônia Vaz de Melo/Coelha-Zona Rural de Viçosa-MG. Viçosa, 2014. 19 p.

RABELO; QUEIROZ; CHAVIER; VIEIRA; MIGLIANO; VALLADÃO. Notas sobre o Moderno: a(s) Carta(s) de Atenas e a emergência do Team X. In: Cronologia do pensamento urbanístico. Salvador: UFBA, 2016. Disponível em: 
<http://www.cronologiadourbanismo.ufba.br/leituras.php?id_leitura=26> Acesso em: 16 ago. 17.

RANCIĖRE, Jacques. O dissenso. In: A crise da razão. São Paulo: Companhia das Letras, p. 367-382, 1996.

RIZEK, Cibele S. Cidade, trabalho, política. In: RIZEK; ROMÃO (org.). Francisco de Oliveira: A tarefa da crítica. Belo Horizonte: Editora UFMG, 2006, p. 209224.

. Discutindo cidades e tempos. Revista Redobra, Salvador, $n^{\circ} 9$.

p 72-74. 2012.

Um balanço de pesquisa: 10 anos na zona leste e um social reconfigurado. In: Revista Cidades, v. 13, n²2, 2017, p. 94-140

RIBEIRO FILHO, Geraldo B. A formação do espaço construído: Cidade e Legislação Urbanística em Viçosa, MG. Dissertação (Mestrado em Urbanismo), Departamento de Arquitetura e Urbanismo - UFRJ, Rio de Janeiro, 1997.

ROLNIK, Raquel. O que é Cidade. Coleção Primeiros Passos. São Paulo: Brasiliense, 2004.

- Informe de la Relatora Especial sobre una vivienda adecuada como elemento integrante del derecho a un nivel de vida adecuado y sobre el derecho de no discriminación a este respecto. Publicación de la Asamblea General de la ONU. Diciembre, 2013.

Guerra dos lugares: A colonização da terra e da moradia na era das finanças. São Paulo: Boitempo, 2015. 
ROSA, Thaís T. Cidades Outras: pobreza, moradia e mediações em trajetórias urbanas liminares. Tese (Doutorado) - Programa de Pós-Graduação em Arquitetura e Urbanismo, Instituto de Arquitetura e Urbanismo da Universidade de São Paulo, 2014.

SANTOS, Cláudio H. M. Políticas federais de Habitação no Brasil: 1964/1998. Brasília: IPEA, jul 1999.

SANTOS, Milton. As cidadanias mutiladas. In: 0 preconceito. São Paulo: Imprensa Oficial do Estado, 1996/1997, p. 133-144.

A urbanização brasileira. São Paulo: EDUSP, 2008.

Pobreza Urbana. São Paulo: Editora da Universidade de São Paulo, 2013.

. Espaço do Cidadão. São Paulo: Edusp, 2014.

SENNETT, Richard. O declínio do homem público: as tiranias da intimidade. São Paulo: Companhia das Letras, 1988.

SERFATY-GARZON, Perla. L'appropriation. Dictionnaire critique de l'habitat et du logement, p. 2-7, 2003.

SERPA, Angelo. O espaço público na cidade contemporânea. São Paulo: Contexto, 2009.

SCHIFFER, Sueli R. As políticas nacionais e a transformação do espaço paulista: 1955-1980. 1989. Tese (Doutorado em Arquitetura e Urbanismo) Escola de Engenharia de São Carlos, Universidade de São Paulo, São Carlos.

SCHMID, Christian. A teoria da produção do espaço de Henri Lefebvre: em direção a uma dialética tridimensional. GEOUSP: Espaço e Tempo (Online), São Paulo, n. 32, p. 89-109, dec. 2012. 
SCHVARSBERG, Benny. Quem disse que ia ser fácil? Dez anos de Estatuto da Cidade, avanços e dilemas, mais moradias e menos cidades: pontos para uma agenda de política urbana comprometida com o direito à cidade. In: RIBEIRO; VAZ; SILVA (org). Leituras da cidade. Rio de Janeiro: Letra Capital: ANPUR, 2012, p. 105-117.

SHIMBO, Lúcia Zanin. Habitação social, habitação de mercado: a confluência entre Estado, empresas construtoras e capital financeiro. Tese (Doutorado em Arquitetura e Urbanismo) - Instituto de Arquitetura e Urbanismo, Universidade de São Paulo. São Carlos, 2010.

SILVA, Medelin; MENDONÇA, Eneida; CARVALHO, André; FERNANDES, Erick. ZONAS ESPECIAIS DE INTERESSE SOCIAL NO PLANO DIRETOR MUNICIPAL: instrumento de inserção urbana - Viçosa, MG. Observatório Geográfico América Latina. Disponível em: <http://www.observatoriogeograficoamericalatina.org.mx/egal14/Geografiasocio economica/Geografiaurbana/053.pdf> Acesso em: 04 set. 2017.

SILVA, Medelin L. da; ANDRADE, Nayan R. de. Estado e mercado imobiliário: o projeto “Minha Casa Minha Vida - Coelha” em Viçosa-MG. I Simpósio Mineiro de Geografia, Alfenas-MG, p. 1139-1153, maio de 2014.

SINGER, Paul I. Economia urbana. In: Economia política e urbanização. São Paulo: Brasiliense, 1979, p. 135-144.

SMITH, Neil. A gentrificação generalizada: de uma anomalia local à "regeneração" urbana como estratégia global. In: BIDOU-ZACHARIASEN, Catharine. De volta à cidade: dos processos de gentrificação às políticas de “revitalização" dos centros urbanos. São Paulo: Annablume, 2006. p. 59-85.

SOUZA, Nilo Sérgio de. As sociabilidades possíveis em conjuntos habitacionais do Programa Minha Casa, Minha Vida (PMCMV): o caso de 
Viçosa-MG. Dissertação (Mestrado em Economia Doméstica) - Departamento de Economia Doméstica, Universidade Federal de Viçosa. Viçosa, 2015.

SPOSATI, A., TORRES, H., PASTERNAK, S., VILLAÇA, F., KOWARICK, L., \& SCHOR, S. (2004). A pesquisa sobre segregação: conceitos, métodos e medições. In: Espaço \& debates n45, p 87-109, 2004.

STEPHAN, Ítalo. OS PROCESSOS PARTICIPATIVOS DO PLANO DIRETOR DE VIÇOSA, MINAS GERAIS, BRASIL. IV Encontro da Associação Nacional de Pesquisa e Pós-Graduação em Arquitetura e Urbanismo, Porto Alegre, 25 a 29 de julho de 2016.

TONIN, Vitor Hugo. Muita gente sem casa, muita casa gente. Entre superlucros e superexploração: a dialética da habitação em país dependente. Dissertação (mestrado em Arquitetura e Urbanismo) Universidade Federal de Santa Catarina, Florianópolis, 2015.

TORRES, Héctor Barrueta; MORANTA, Tomeu Vidal. La noción de espacio público y la configuración de la ciudad: fundamentos para los relatos de pérdida, civilidad y disputa. Polis, Santiago, v. 11, n. 31, p. 57-80, abril de 2012.

VALLADARES, Lícia do Prado. Estudos Recentes sobre a Habitação no Brasil: Resenha da Literatura. In: (org). Repensando a Habitação no Brasil. Rio de Janeiro: Zahar Editores, 1983, pp. 21-77.

VELLOSO, Rita de Cássia L. Na vida das ruas: escrevendo muito depois de Heidegger. In: Arquitextos. Disponível em: <http://www.vitruvius.com.br/> Acessado em: nov. 2016.

VIÇOSA. Decreto-lei $n^{\circ} 2216$, de 03 de julho de 1876. Eleva a Vila de Santa Rita do Turvo à categoria de cidade, recebendo o nome de Viçosa de Santa Rita. 
VIÇOSA. Lei no 2.173 , de 19 de setembro de 2011. Dispõe sobre denominação de vias públicas no. Conjunto Habitacional Benjamin José Cardoso e dá outras providências.

VIÇOSA. Lei oㅜ 1.383, de 25 de maio de 2000. Institui o Plano Diretor de Viçosa.

VILLAÇA, Flávio. A TERRA COMO CAPITAL (ou a TERRA-LOCALIZAÇÃO). Revista Espaço \& Debate ANO V, n¹6, 1985.

. O que todo cidadão precisa saber sobre habitação. São Paulo: Global, 1986, 122p.

. O território e a dominação social. In: Margem Esquerda. São Paulo: Boitempo Editorial, n. 24, p. 31- 36, 2015.

VOGEL, Arno; VOGEL, Vera Lúcia de O; LEITÃO, Gerônimo E. de Almeida. Como as crianças vêem a cidade. Rio de Janeiro: Pallas: Flacso: UNICEF, 1995.

ZACCHI, Raquel C. O espaço urbano da cidade capitalista: um estudo sobre o processo de verticalização da área central da cidade de Viçosa (MG) (1970-2007). Brazilian Geografic Journal: Geoscience and Humanities research medium, Ituiutaba, Dezembro de 2014. p. 352-370.

ZUIN, Antonio Álvaro Soares. Sobre a atualidade do conceito de indústria cultural. In: Cadernos Cedes, v. 21, n. 54, p. 9-18, 2001. 
ANEXOS 


\section{MAPA DE LOCALIZACÃO DOS BAIRROS NA MALHA URBANA}

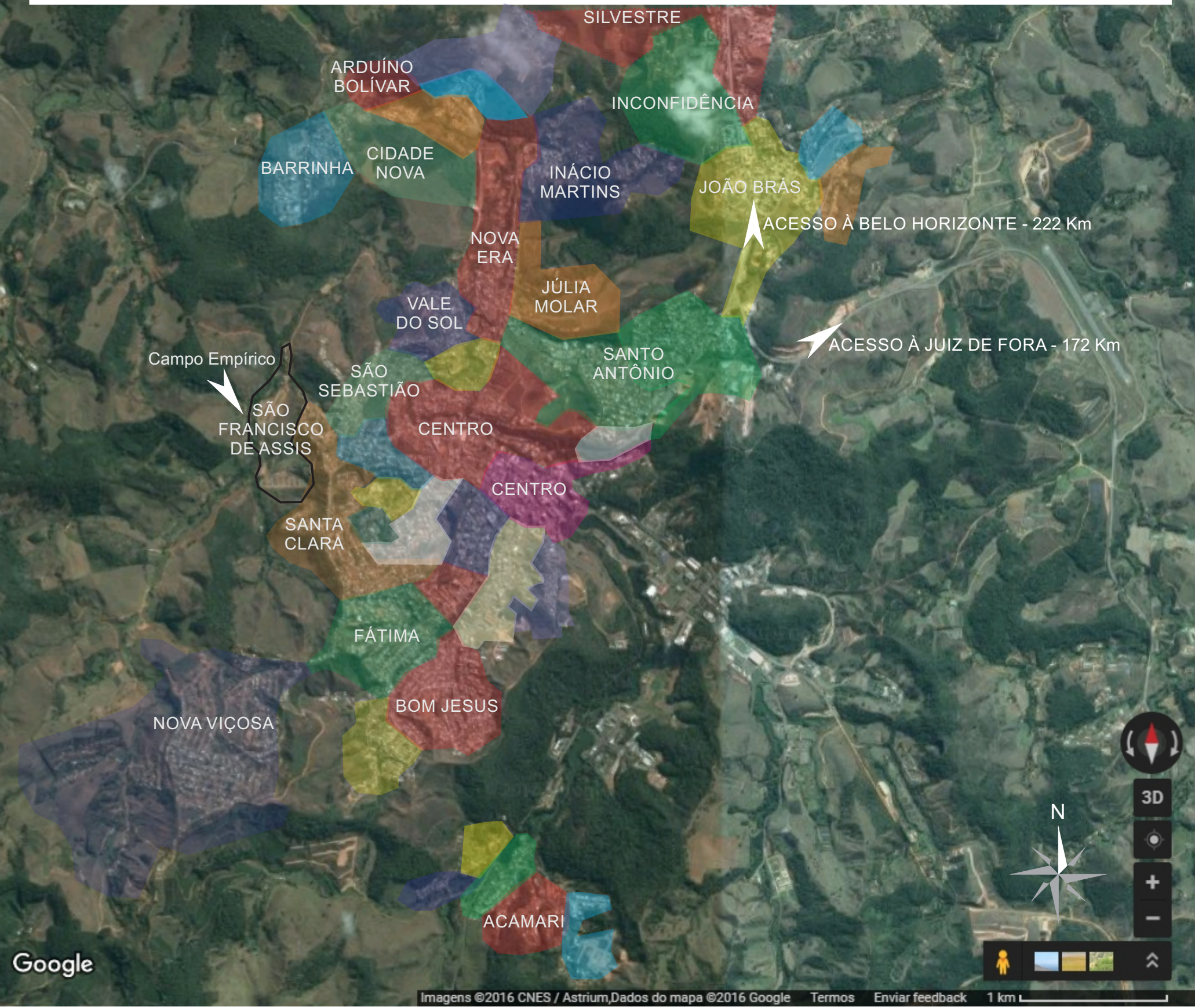

FONTE: GOOGLE EARTH, MODIFICADO PELO AUTOR/ AGO. 2016 


\section{MAPA DE LOCALIZACÃO DOS CONJUNTOS NA MALHA URBANA}

\section{Google}

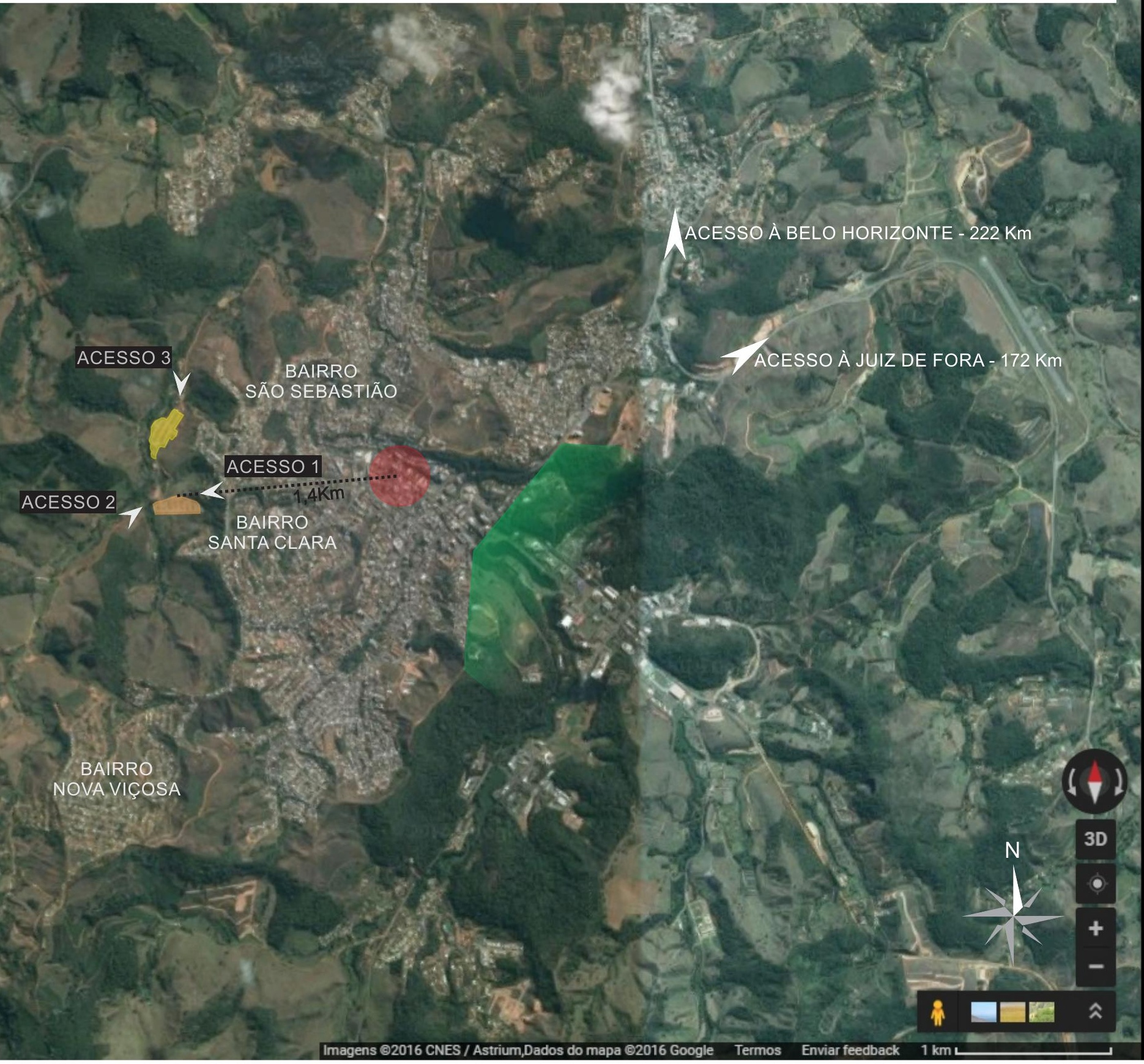

FONTE: GOOGLE EARTH, MODIFICADO PELO AUTOR/ AGO. 2016

(1) CONJUNTO HABITACIONAL BENJAMIN CARDOSO CONJUNTO HABITACIONAL CÉSAR SANTANA FILHO

Centro de VIÇOSA

- ÁREA DA UNIVERSIDADE FEDERAL DE VIÇOSA 


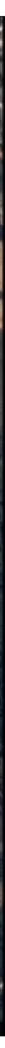

CONJUNTO HABITACIONAL BENJAMIN CARDOSO

FONTE: GOOGLE EARTH, MODIFICADO PELO AUTOR/ AGO. 2016

CONJUNTO HABITACIONAL CÉSAR SANTANA FILHO

- PRAÇA DO BAIRRO SANTA CLARA

- ASSOCIAÇÃo ESPORTIVA DE VIÇOSENSE

- ACESSOS À UNIVERSIDADE FEDERAL DE VIÇOSA

- PRAÇA SILVIANO BRANDÃO

- PRAÇAS DOS CONJUNTOS

- TERRENOS BALDIOS UTILIZADOS COMO ÁREAS DE LAZER 

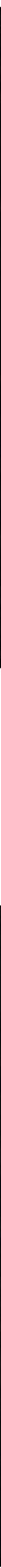

PAVIMENTAÇÃO EM BLOQUETE

FONTE: GOOGLE EARTH, MODIFICADO PELO AUTOR/ AGO. 2016 PAVIMENTAÇÃO EM ASFALTO

- PAVIMENTAÇÃO EM PEDRA FINCADA

CANALETA DE ESCOAMENTO DE ÁGUA PLUVIAL (CAMINHO INFORMAL: ESCADÃO)

ESTRADA DE TERRA

DELIMITAÇÃO DO TOPO DO MORRO

- PONTOS DE ÔNIBUS 

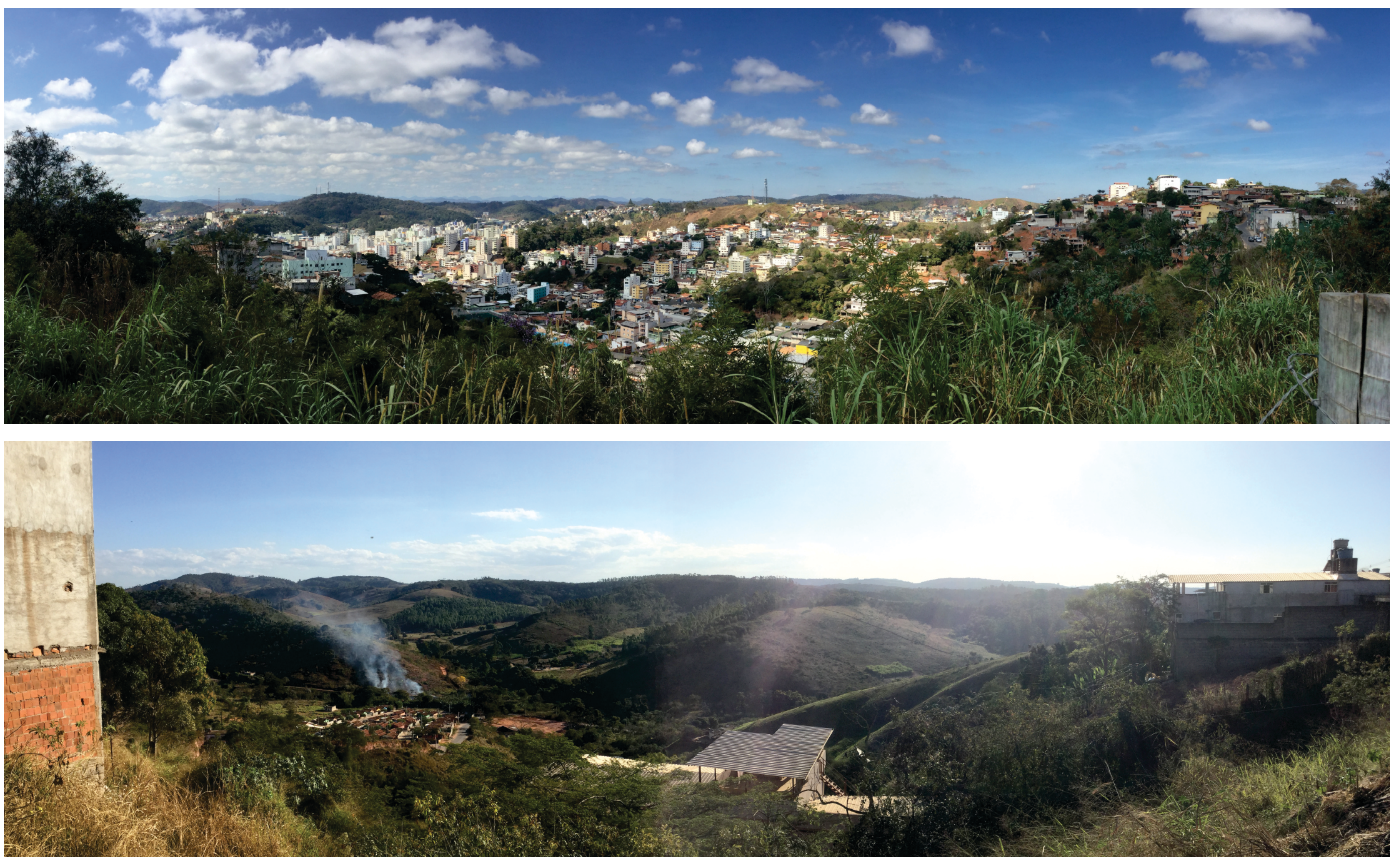

Vistas panorâmicas do ponto mais alto do Bairro Santa Clara, olhando para o Centro da cidade, na primeira imagem; e para os Conjuntos Habitacionais, na segunda imagem. 
